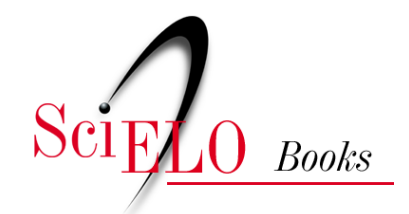

Editora da UESC

\title{
Geografia e ensino dimensões teóricas e práticas para a sala de aula
}

\author{
Gilmar Alves Trindade \\ Gilsélia Lemos Moreira \\ Lurdes Bertol Rocha \\ Maria Cristina Rangel \\ Rita Jaqueline Nogueira Chiapetti
}

TRINDADE, G.A., MOREIRA, G.L., ROCHA, L.B., RANGEL, M.C., and CHIAPETTI, R.J.N.

Geografia e ensino: dimensões teóricas e práticas para a sala de aula [online]. Ilhéus: Editus, 2017, 264 p. ISBN: 978-85-7455-526-3. https://doi.org/10.7476/9788574555263.

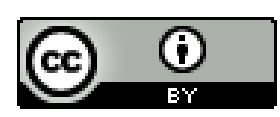

All the contents of this work, except where otherwise noted, is licensed under a Creative Commons Attribution $\underline{4.0 \text { International license. }}$

Todo o conteúdo deste trabalho, exceto quando houver ressalva, é publicado sob a licença $\underline{\text { Creative Commons }}$ Atribição 4.0. 


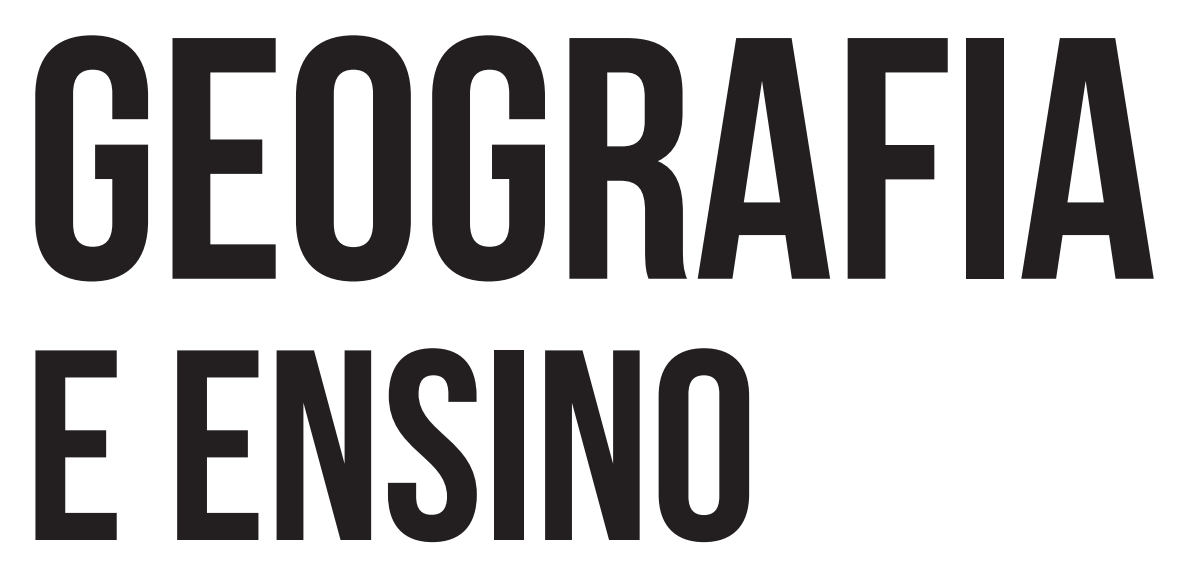

DIMENSÕES TEÓRICAS E PRÁTICAS PARA A SALA DE AULA

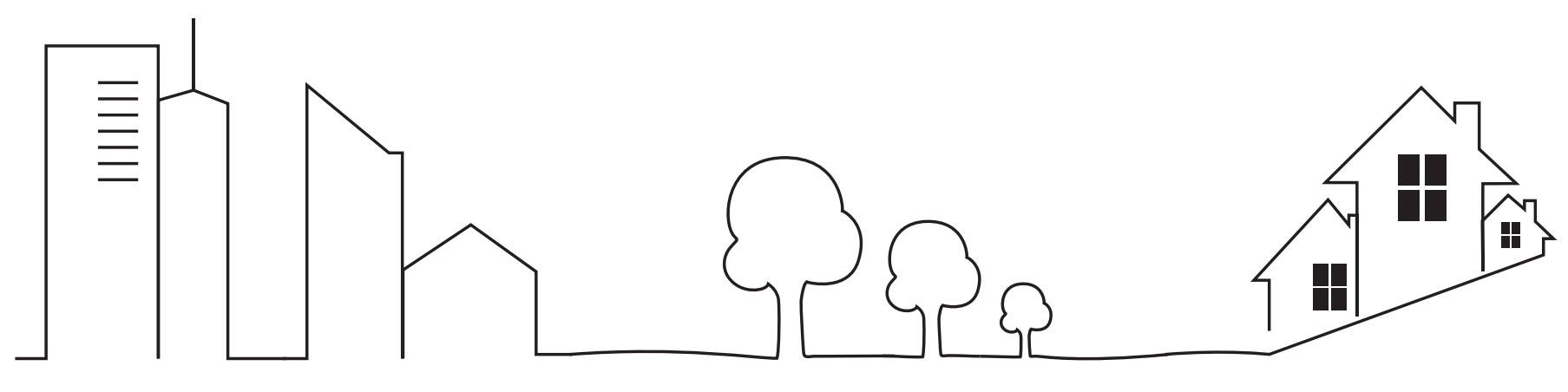




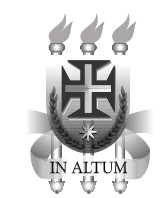

\section{Universidade Estadual de Santa Cruz}

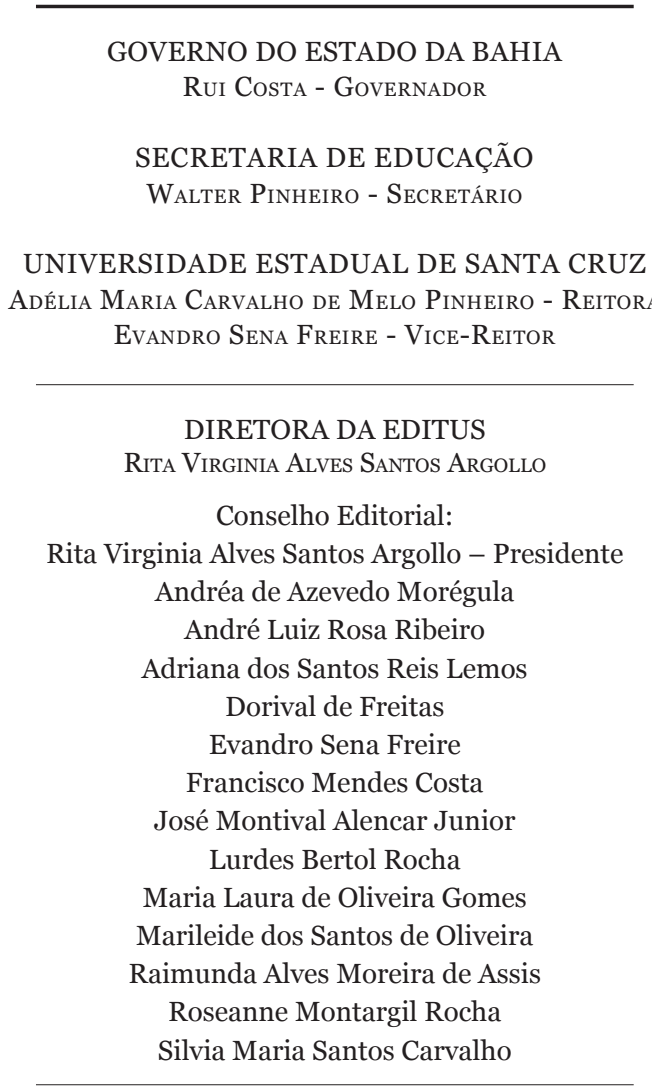




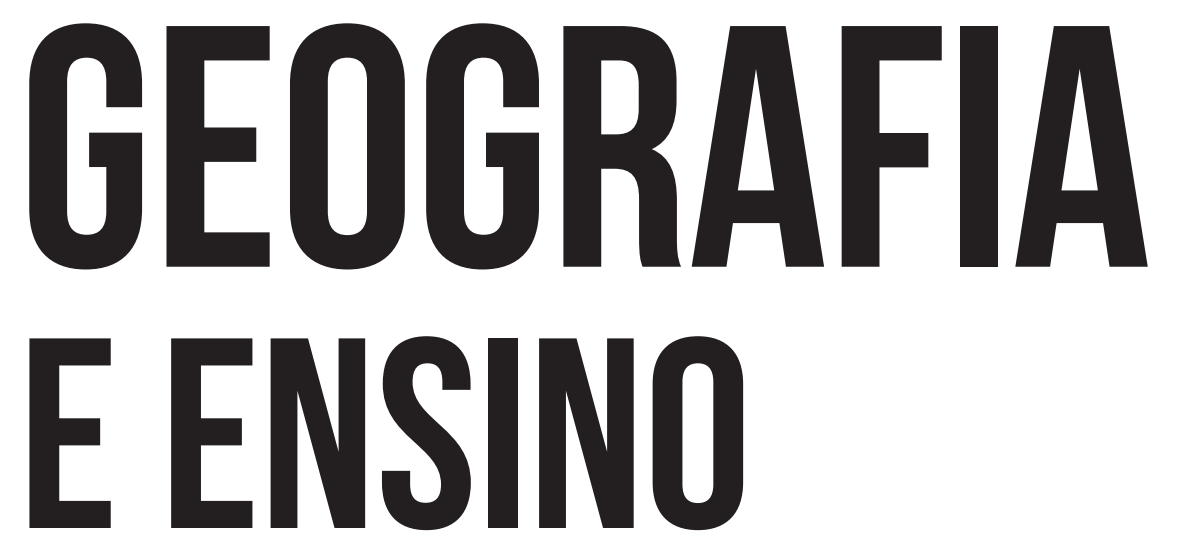

\title{
DIMENSÕES TEÓRICAS E PRÁTICAS PARA A SALA DE AULA
}

\author{
Gilmar Alves Trindade \\ Gilsélia Lemos Moreira \\ Lurdes Bertol Rocha \\ Maria Cristina Rangel
}

Rita Jaqueline Nogueira Chiapetti

Ilhéus-BA

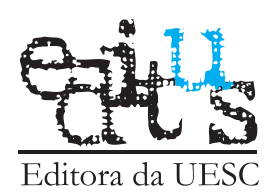


Copyright (C)2017 by

Gilmar Alves Trindade

Gilsélia Lemos Moreira

LURDES BERTOL ROCHA

Maria CRistina Rangel

Rita Jaqueline Nogueira Chiapetti

Direitos desta edição reservados à

EDITUS - EDITORA DA UESC

A reprodução não autorizada desta publicação, por qualquer meio, seja total ou parcial, constitui violação da Lei n ${ }^{\circ}$ 9.610/98.

Depósito legal na Biblioteca Nacional,

conforme Lei no 10.994 , de 14 de dezembro de 2004.

PROJETO GRÁFICO E CAPA

Deise Francis Krause

REVISÃO

Genebaldo Pinto Ribeiro

Maria Luiza Nora

Roberto Santos de Carvalho

Dados Internacionais de Catalogação na Publicação (CIP)

G345 Geografia e ensino : dimensões teóricas e práticas

para a sala de aula / Gilmar Alves Trindade ... [et al.]

. - Ilhéus, BA : Editus, 2017.

264 p. : il.

Inclui referências.

ISBN: 978-85-7455-431-O

1. Geografia - Estudo e ensino. 2. Prática de ensino.

I. Trindade, Gilmar Alves.

CDD 910.7

EDITUS - EDITORA DA UESC

Universidade Estadual de Santa Cruz

Rodovia Jorge Amado, km 16 - 45662-90o - Ilhéus, Bahia, Brasil

Tel.: (73) 3680-5028

www.uesc.br/editora

editus@uesc.br

EDITORA FILIADA À

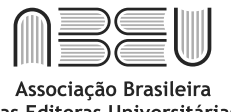

das Editoras Universitárias 


\section{SOBRE OS AUTORES}

\section{GILMAR ALVES TRINDADE}

Doutor em Geografia, área de Análise regional, pela Universidade Federal de Sergipe, com a defesa da tese: Aglomeração Itabuna-Ilhéus: cidade, região e rede urbana, sob a orientação da Professora Doutora Vera Lúcia Alves França. Mestre em Geografia, na área de Planejamento Urbano e regional pela Universidade Federal da Bahia. Licenciado em Geografia pela Universidade Estadual de Santa Cruz (UESC-BA). Professor Adjunto da Universidade Estadual de Santa Cruz, Ilhéus-BA. Atuando na área de Geografia, especialmente em temas relacionados à Geografia urbana, Geografia regional, Epistemologia em Geografia e Ensino de Geografia. Tem livros e capítulos de livros publicados pela Editus/UESC e pela Editora da UFS-SE, além de artigos publicados em revistas científicas na área da Geografia e dos Estudos regionais.

\section{GILSÉLIA LEMOS MOREIRA}

Doutora em Geografia Humana pela Universidade de São Paulo USP. Licenciada em Geografia e Especialização em Ensino de Geografia pela Universidade Estadual do Sudoeste da Bahia - UESB. Mestre em Desenvolvimento Regional e Meio Ambiente pela Universidade Estadual de Santa Cruz - UESC. Professora da Universidade Estadual de Santa Cruz - UESC. Leciona nos Cursos de Licenciatura e Bacharelado em Geografia. Já lecionou na Universidade Estadual do Sudoeste da Bahia - UESB e na Faculdade Don Domênico (Guarujá-SP). É coordenadora do curso de Espacialização em Ensino de Geografia. Pesquisadora associada ao Grupo de estudos de Geografia Urbana Crítica Radical, vinculado ao Laboratório de Geografia Urbana (LABUR/DG/FFLCH/USP). Membro efetivo do Instituto Histórico e Geográfico de Santos - SP. Cadeira n ${ }^{\circ}$. 16. Autora de vários artigos na área de Geografia de Humana e Ensino. Desde 1998 estuda e escreve sobre a produção do espaço urbano. Concentra leituras e estudos sobre as obras de Henri Lefebvre. Suas pesquisas e reflexões se voltam, principalmente, para os seguintes temas: produção do espaço urbano, segregação espacial, verticalização, turismo e ensino de Geografia. 


\section{LURDES BERTOL ROCHA}

Doutora em Geografia pela Universidade Federal do Sergipe, com a defesa da tese: A região cacaueira da Bahia - uma abordagem fenomenológica, tendo como orientadora a professora Doutora Barbara-Christine Nentwig Silva. Mestre em Geografia, na área de Planejamento Urbano e Regional pela Universidade Federal da Bahia. Pós-graduação lato sensu em Geografia Humana (FAFITO) e Desenvolvimento e Gestão Ambiental (UESC). Licenciada em Ciências Sociais pela Faculdade de Filosofia Ciências e Letras de Teófilo Otoni (FAFITO-MG). Professora titular aposentada (junho 2014) da Universidade Estadual de Santa Cruz -UESC, Ilhéus - BA. Atuou na área de Geografia, principalmente em temas relacionados à Geografia da Percepção, Fenomenologia, Semiótica, tais como: mapa mental, signo, linguagem verbal, funções e significados das praças de Itabuna, transformação do centro urbano, percepção da região cacaueira da Bahia. Tem vários livros e capítulos de livros publicados pela Editus/UESC e artigos em diversas revistas científicas nacionais.

\section{MARIA CRISTINA RANGEL}

Doutora em Geografia pela Universidade Estadual de Maringá (UEM). Mestre em Geografia pela Universidade de São Paulo (USP), Bacharelado e Licenciatura em Geografia pela Universidade Estadual Paulista Júlio de Mesquita Filho (Unesp de Presidente Prudente). Atualmente é professora da Universidade Estadual de Santa Cruz (UESC). Tem experiência na área de Geografia, com ênfase em Geografia da População e Geografia Política.

\section{RITA JAQUELINE NOGUEIRA CHIAPETTI}

Doutora em Geografia pela Universidade Estadual Paulista Júlio de Mesquita Filho - UNESP, de Rio Claro-SP (2009). Mestre em Geografia pela Universidade Federal de Santa Catarina - UFSC (1994). Graduada nos Cursos de Licenciatura e Bacharelado em Geografia pela Universidade Federal do Paraná - UFPR (1988). Professora Adjunta na Universidade Estadual de Santa Cruz - UESC, em Ilhéus-BA, desde 1998, lecionando nos Cursos de Licenciatura e Bacharelado em Geografia e Especialização em Ensino de Geografia. Áreas em que atua: Normatização e Redação Técnico-científica, Ensino de Pesquisa em Geografia, Geografia Humanista, Percepção Ambiental e Organização do Espaço Geográfico. 


\section{JORGE CHIAPETTI}

Doutor em Geografia, professor Adjunto do Departamento de Ciências Agrárias e Ambientais (DCAA) da Universidade Estadual de Santa Cruz (UESC), Ilhéus-BA. Seus trabalhos concentram-se em formação territorial, desenvolvimento regional, agricultura e sustentabilidade.

\section{TEREZA G. N. TOREZANI FONTES}

Mestre em Desenvolvimento Regional e Meio Ambiente. Especialização em Educação Geo-Ambiental pela FACSUl-BA (2007). Graduada em Geografia pela Universidade Estadual de Santa Cruz (2003). Professora Auxiliar do Curso de Licenciatura em Geografia da Universidade Estadual de Santa Cruz - UESC - BA. Tem experiência na área de Geografia, com ênfase em Geografia Humana e Ensino de Geografia atuando principalmente nos seguintes temas: Ensino de Geografia, Estágio Supervisionado em Geografia e Metodologia de Ensino em Geografia.

\section{ADERBAL PEREIRA SANTANA FILHO}

Mestre em Desenho, Cultura e Interatividade (2014), pela UEFS; especialista em Ensino de Geografia (2014) pela UESC; especialista em Ensino da Geografia (2011), pela FINON e graduação (licenciatura) em Geografia pela UESC (2006). Atua no Ensino Básico (Secretaria de Educação do Estado da Bahia e rede privada), com as disciplinas de Geografia e Atualidades. Membro do Grupo de Pesquisa Desenvolvimento Humano e Processos educativos (DEHPE-UEFS). Experiência com a educação indígena, centrada nos mapas mentais e na percepção do lugar de vivência e do território simbólico, bem como na Geografia Humanista e Fenomenologia.

\section{CAMILA SANTANA CARRIÇO}

Doutoranda na Universidade Federal de Minas Gerais (UFMG). Mestrado em Química Inorgânica pela Universidade Federal da Bahia (UFBA) e graduação em Química pela Universidade Estadual de Santa Cruz (UESC). Tem experiência, principalmente, nas áreas de energia renovável, síntese de materiais, biomateriais e catálise.

\section{CELENE TONELLA}

Doutora em História pela Universidade Estadual Paulista Júlio de Mesquita Filho (Unesp), mestrado em Ciência Política pela Universidade Estadual de Campinas (Unicamp) e graduação em Ciências Sociais 
(Unicamp). Atualmente é professora associada do Departamento de Ciências Sociais e do Programa de Pós-Graduação em Ciências Sociais e Políticas Públicas da Universidade Estadual de Maringá (UEM). É pesquisadora vinculada à rede Observatório das Metrópoles/Institutos Nacionais/ CNPq 2009-2013. Foi assessora especial do gabinete da reitoria da UEM em Relações Institucionais e Políticas Públicas (2011-2014). Tem experiência nas área de Ciência Política e Sociologia Urbana, com ênfase em comportamento político e gestão urbana, atuando principalmente com os seguintes temas: democracia e participação política, espaço urbano, cidadania, políticas públicas e trabalhadores.

\section{GLÓRIA MARIA DE OLIVEIRA SILVA}

Graduada em Geografia pela Universidade do Estado da Bahia (UNEB). Especialização em Ensino de Geografia pela Universidade Estadual de Santa Cruz (UESC). Professora no Ensino Fundamental II na rede Estadual de ensino. Tem experiência na área de Geografia, com ênfase em Geografia Humana.

\section{KAREN DE JESUS}

Doutoranda do programa de Pós-graduação em Química da USP, com linha de pesquisa voltada para a Química de Produtos Naturais Marinhos. Mestrado em Química pela Universidade de São Paulo (IQSC -USP, área de concentração Química Orgânica e Biológica). Graduada em Química pela Universidade Estadual de Santa Cruz (UESC).

\section{LINCOLN SANTOS DOS REIS}

Graduado em Geografia pela Faculdade Pitágoras (2008). Especialista em Ensino de Geografia UESC - Universidade Estadual de Santa Cruz. Professor efetivo de Geografia da secretaria municipal de educação e cultura de Teixeira de Freitas.

\section{LUZIANA CARVALHO DOS SANTOS}

Graduada em Geografia. Especialização em Ensino de Geografia pela Universidade Estadual de Santa Cruz (UESC). Especialista em Psicopedagogia Clínica e Institucional. Tem experiência na área de Geografia, com ênfase em Ensino de Geografia atuando nos seguintes temas: Cidadania, Dificuldades na Aprendizagem, Educação Ambiental, Educação Especial e Ensino de Geografia. 


\section{NAMARA SANTOS LOPES}

Graduada em GEOGRAFIA pela Universidade Estadual de Santa Cruz (2006), MESTRADO em Desenvolvimento Regional e Meio Ambiente (2009). Tem experiência na área de Geografia, com ênfase em geografia física, atuando principalmente nos seguintes temas: Conservação da Biodiversidade, Conservação de Bacias Hidrográficas, Manejo Florestal e Sistemas de Informações Geográficas 


\section{SUMÁRIO}

PREFÁCIO

15

\section{SEÇ̃̃O I \\ ENSINO DE GEOGRAFIA: \\ INQUIETAÇ̃̃ES EM TORNO DA DIMENSÃ̃ TEÓRICO-PRÁTICA}

NOVAS CONFIGURAÇÕES GEOGRÁFICAS

A PARTIR DO TEMPO E DO ESPAÇO

19

APLICAÇÃO DOS CONCEITOS GEOGRÁFICOS

NO ENSINO FUNDAMENTAL E MÉDIO

29

OS PROFESSORES DE GEOGRAFIA ENSINANDO

A PESQUISAR NA ESCOLA

36

A VIOLÊNCIA NO ESPAÇO ESCOLAR:

da segurança do cotidiano ao cotidiano da insegurança

48

O ENSINO DE GEOGRAFIA NUM MUNDO DOMINADO PELA MÍDIA, PERMEADO PELA IMAGEM E SUBMETIDO AO ESPETÁCULO

$$
58
$$




\title{
SECÃO II \\ ENSINO DE GEOGRAFIA: DIMENSÕES TEÓRICAS PARA REFLEXÃOE AUXÍLIO À PRÁTICA EM SALA DE AULA
}

\author{
RIO ALMADA: \\ agonia de uma alma hídrica \\ 70 \\ O PROCESSO DE METROPOLIZAÇÃO DO TERRITÓRIO \\ BRASILEIRO: uma abordagem para ampliar o debate no ensino de \\ Geografia \\ 86 \\ RELATO DE UMA PESQUISA DE CAMPO QUALITATIVA \\ SEGUNDO OS PROPÓSITOS DA GEOGRAFIA HUMANISTA \\ 106
}

PARA ALÉM DO “DESCOBRIMENTO” DO BRASIL: notas sobre a formação territorial do sul da

Bahia para o ensino da Geografia

134

ANÁLISE DO TERRITÓRIO EM MICHEL FOUCAULT:

o território como locus do poder

$$
160
$$

A PAISAGEM NO ESPAÇO DA VIDA:

do vivido ao refletido

174 


\section{SECÃO III \\ ENSINO DE GEOGRAFIA: DIMENSÕES PRÁTICAS PARA O COTIDIANO \\ EM SALA DE AULA}

O ENSINO DE GEOGRAFIA NA ESCOLA INDÍGENA:

percebendo os olhares

192

O PORTO DE SANTOS, VIVÊNCIAS, PERCEPÇÕES E SENTIMENTOS ALÉM DOS MUROS DA ESCOLA:

um relato de esperiência e prática

218

A SALA TEMÁTICA COMO UM RECURSO

DIDÁTICO NAS AULAS DE GEOGRAFIA

236

A LITERATURA COMO RECURSO

NO ENSINO DE GEOGRAFIA:

$7^{\circ}$ ano do ensino fundamental

250 


\section{PREFÁCIO}

Vivemos um tempo de preocupações muito evidentes sobre o atual processo educativo das sociedades, em todo o mundo, até porque estamos vivendo uma era marcada por realidades humanas assentadas em profundas alterações sociopolíticas, econômicas, tecnológicas, ambientais e educacionais que necessitam de homens e mulheres qualificados(as), prontos(as) a atenderem as novíssimas demandas dessas mesmas sociedades, ou seja, desse novo tempo histórico. Daí que, amparada nesta convicção, penso que novas formas de produzir, aprender e ensinar Geografia, ciência que nos prepara para sermos leitores do mundo, colocam-se como de essencial importância no processo de formação dessas pessoas.

Este livro, que tenho o prazer de prefaciar, é o resultado de um esforço conjunto de reflexões de profissionais da educação geográfica, em grande parte lotados na Universidade Estadual de Santa Cruz (UESC), sul da Bahia, que moldam e apresentam um rico e profundo painel das diversas facetas e possibilidades de produzir, aprender e ensinar Geografia no contexto da sociedade contemporânea.

Partindo dessa compreensão, permito-me afiançar que esta obra é uma produção coletiva de exímios especialistas que se debruçam cotidianamente sobre o repensar dos caminhos da educação geográfica, nas escalas local, regional, nacional e/ou global, vivenciando múltiplas experiências com a pesquisa e as práticas educativas em ensino de Geografia, sempre atentos à necessidade de promover e garantir a articulação de matrizes teóricas distintas e os seus diferentes olhares sobre o espaço e o tempo, categorias embrionárias e indispensáveis à ciência geográfica, assim como os conceitos de território, região, lugar e paisagem, e tantos outros, reconhecidos como modernos e pós-modernos.

A obra se intitula Geografia e Ensino: dimensões teóricas e práticas para a sala de aula, organizada no formato de seções (I, II e III), tendo como ponto fulcral o ensino de Geografia, com importantes discussões teóricas e reflexões sobre o papel e a importância da pesquisa escolar, além de apresentar outras experiências que se colocam como possibilidades metodológicas para a melhoria da qualidade do ensino de Geografia, em especial na educação básica. Sustento o argumento de que os autores também possuem uma forte preocupação didática, considerando que traçam caminhos, sustentam concepções e apresentam propostas didático-pedagógicas capazes de enriquecer as práticas educativas nos espaços escolares. 
Por fim, posso concluir que os autores da seção I desenvolvem reflexões sobre as dimensões teórico-práticas da disciplina em questão; os da seção II tratam da reflexão e do auxílio à prática em sala de aula; e os da seção III se desdobram na produção de trabalhos que cuidam das dimensões práticas para o cotidiano em sala de aula. A obra, como um todo, é multifacetada. Os autores caminham de forma absolutamente livre e lidam com as suas questões nos mais variados tons, do acadêmico ao poético, por exemplo, mas se encontram naquilo que é central no livro: a preocupação com a melhoria do ensino de Geografia.

Itabuna, 18 de setembro de 2014

Clarice Gonçalves Souza de Oliveira Prof ${ }^{a}$. Assistente de Geografia da UESC (aposentada) 


\section{SEÇÃOI}

\section{ENSINO DE GEOGRAFIA: INQUIETAĞ̃̄ES EM TORNO DA DIMENSÃO TEÓRICO-PRÁTICA}

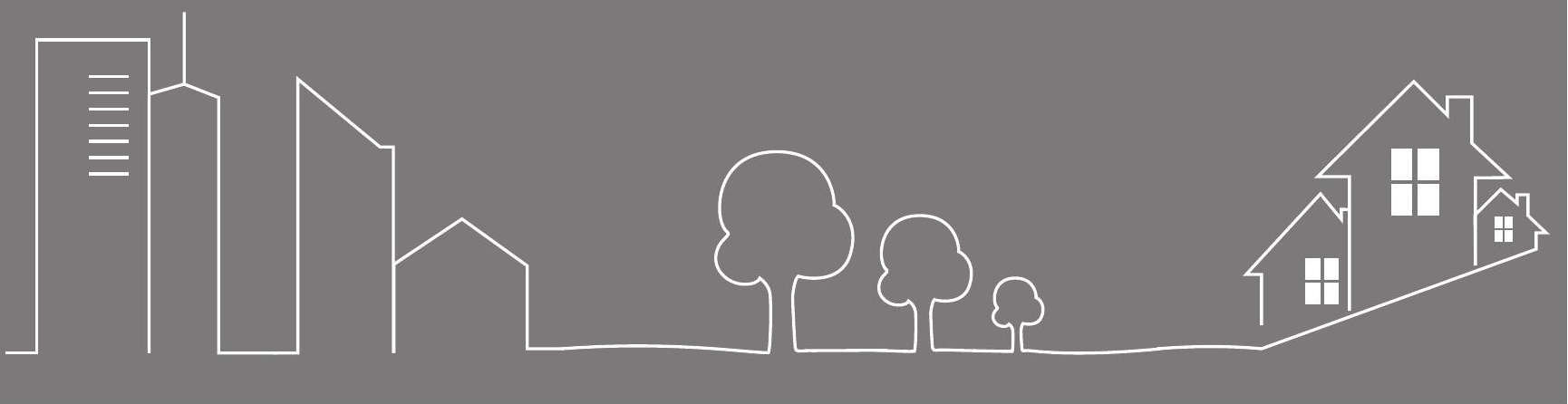




\section{NOVAS \\ CONFIGURAÇÕES \\ GEOGRÁFICAS A PARTIR \\ DO TEMPO E DO \\ ESPAÇO}

\section{Lurdes Bertol Rocha}

\section{O tempo}

O tempo não é fonte

Muito menos o leito.

Ele se faz um rio

Que corre pelos corpos e almas

Como um lago corre

Pelas margens e os leitos.

O tempo não é brisa

Muito menos a tempestade.

Ele se faz uma gota de orvalho

Que cai docemente sobre um corpo Ou ultrapassa velozmente uma alma.

O tempo não é o destino

Muito menos a felicidade.

Ele se faz constante na história

E muda a cada instante o sentido

Não tem medida nem fim.

O tempo não é uma face certa

Muito menos um rosto incerto.

Ele se faz tão presente a todos

Como misterioso e ausente

Sob explicações da gente.

O tempo não é um pensamento

Muito menos uma realidade.

Ele se faz um sonho incerto

Uma torrente de águas puras

Uma brisa suave e cheia de candura

Um destino bom e amigo

De feições conhecidas e olhares gentis

Que para qualquer um tem

A sua significação tão certa

E ao mesmo tempo tão incerta.

Ducilene Arruda 
Não há como separar tempo e espaço. Os dois sempre estiveram imbricados, um em função do outro. Tanto é assim que, para cristalizar o tempo que corre pelo espaço (ou é o espaço que corre pelo tempo, ou os dois correm juntos?), foi criado o relógio. Este é uma tentativa de confinar o tempo dentro de um espaço (ou confinar o espaço no tempo?). Os ponteiros levam 12 horas para percorrer uma vez o espaço que os confina.

Seu significado, porém (tempo e espaço), mudou ao longo do tempo. O espaço já foi compreendido como extensão, como dimensão euclidiana (superfície: altura, largura e comprimento). Ao acompanhar a saga da humanidade, tempo e espaço foram adquirindo as conotações específicas de cada momento histórico. Ou terá sido o inverso? Castells (1999, p. 403) afirma que: "O espaço e o tempo são as principais dimensões materiais da vida humana”.

Nesta breve incursão pelas configurações geográficas criadas pelas relações do homem, no tempo e no espaço, com a natureza; dos homens com os homens; das relações humanas entre si e sua apropriação da natureza colocando-a a seu serviço, procurarei entender esse processo. Isto será possível fazendo uma caminhada ao longo da história, a partir do surgimento do capitalismo como forma de apropriação da força do trabalho para fazer acontecer a produção, a circulação, o consumo para a acumulação. Daí, levar à produção, circulação, consumo e acumulação. Assim como numa mandala, partindo do centro e se expandindo, sempre mais para fora, alargando-se, chegando aos confins do planeta, sem perder a origem, o centro, para onde volta, e daí se expandindo num movimento infinito de ida e vinda.

Maquiavel (2002, p. 66), no século XVI, referia-se ao espaço como um espaço rígido, com fronteiras definidas, um espaço-extensão, espaçosuperfície, linear.

As cidades da Alemanha [...] têm pouco território. [...] são fortificadas de tal modo que todos pensam que expurgá-las deva ser demorado. Todas têm fossos e muralhas convenientes, têm artilharia suficiente [...].

Naquela época, território e solo significavam a mesma coisa. Além disso, significavam, também, poder. Só que este poder tinha limites rígidos, as fronteiras determinadas por muros e fossos. A configuração espaço/ poder era passível de ser matematicamente cartografada.

Espaço é poder. Esta constatação aparece de forma contundente nos textos dos pensadores alemães, principalmente de Ratzel que, no final 
do século XIX, início do século XX, sistematizou o pensamento alemão, mostrando a configuração geográfica do mundo na época, baseada na extensão territorial, entendida aqui como solo, como superfície. Neste tipo de configuração, as fronteiras eram rígidas, o poder de um estado-nação seria maior quanto maior fosse sua extensão territorial. Isto já vinha desde a corrida para adquirir territórios ultramarinhos nos séculos XV e XVI e, no período ratzeliano, extensão também das fronteiras contíguas para garantir o espaço vital.

O capitalismo foi o grande responsável pela expansão territorial (solo), elastecendo as fronteiras além-mar a fim de aumentar o poder, aumentando o estoque de recursos minerais, principalmente o ouro. São os recursos do subsolo que passam a significar o controle dos mares e, com isso, o controle das áreas onde este metal ocorria em abundância ou que se acreditasse existir. Ao se dominar os mares, dominam-se os continentes e, ao dominar os continentes, domina-se o coração (heartland da antropogeografia de Ratzel). Aqui aparece a visão organicista, que tem o coração como órgão vital para a vida e para a morte. Ou seja, quem tem o domínio dos continentes, o domínio dos mares, terá o poder de deixar viver ou morrer os locais que interessam aos dominadores. Daí o controle do estreito de Behring, do canal de Panamá, de Bósforo, que seriam as "muralhas" que permitiriam a entrada dos dominadores e impediriam a entrada dos que chegassem depois.

Com a Revolução Industrial, no século XVIII, iniciada na Europa (Inglaterra), surgem novas tecnologias que vão dar outra dimensão ao domínio dos espaços. No primeiro período dessa revolução, as novas tecnologias foram representadas pela máquina a vapor (diminui o tempo/ distância de travessia dos mares), pela fiandeira, que agiliza o processo de formação do fio para a confecção do tecido, enfim, a substituição das ferramentas manuais pelas máquinas. Na segunda fase da revolução industrial, o destaque é para o desenvolvimento da eletricidade, do motor de combustão interna, início das tecnologias de comunicação (telégrafo, telefone). Após a segunda metade do século XIX, foi de fundamental importância o conhecimento científico para sustentar e dar continuidade ao desenvolvimento tecnológico (CASTELLS, 2002). O conhecimento científico passou a ser, cada vez mais, o fato mais importante para se afirmar o domínio e o poder sobre as nações.

Com o domínio do conhecimento, do avanço tecnológico, o desenvolvimento nas várias regiões do planeta passa a ser desigual. Na tradição marxista (SMITH, 1988), desenvolvimento é utilizado nos sentidos político, econômico e filosófico. Para essa tradição, o desenvolvimento desigual 
é uma lei universal da história, é a essência da contradição. Para o autor, assim como há a tendência para a diferenciação entre as regiões, há, também, a tendência para a igualização.

$\mathrm{Na}$ diferenciação, desde os tempos mais remotos, já havia uma tendência natural para esse fenômeno. Isso se manifestava já na mais antiga divisão do trabalho entre os sexos: as mulheres mais dedicadas ao trabalho doméstico e ao trabalho da terra próximo de sua morada. Já os homens se dedicavam mais à caça e à procura de alimentos em lugares mais distantes. Com isso, o sexo masculino desenvolveu um domínio espacial mais amplo. Essa diferenciação natural do trabalho foi a base para a diferenciação social. As diferenças qualitativas na natureza se traduzem em diferenças qualitativas e quantitativas na organização social. "A divisão social do trabalho se expressa espacialmente” (SMITH, 1988, p. 153). Na Geografia Tradicional,

concentração espacial da riqueza era vista primeiramente como o resultado da diferenciação natural na fisiografia, nos recursos, no clima (SMITH, 1988, p. 154).

A Geografia Comercial foi a tentativa mais sofisticada de relacionar as diferenciações dos dons naturais com a concentração de capital. Essa Geografia descrevia a variedade dos produtos vindos das mais diversas regiões do mundo e justificava a diferenciação nas produções agrícolas e industriais como diferentes dádivas da natureza. Essa forma de pensar o desenvolvimento desigual era a Geografia do capitalismo comercial, mais desenvolvida na Grã-Bretanha, que era o centro comercial do século XIX. Com a queda do Império Britânico, a Geografia Comercial perdeu sua importância. Ainda de acordo com Smith (1988), para Marx, a divisão social se dá a partir da divisão do trabalho (geral, particular e específica) e divisão do capital que, por sua vez, dividem-se em departamentos, setores e unidades individuais de propriedade que, resumidos, aparecem no QUADRO 1. 
QUADRO - Diferenciação social a partir da divisão do trabalho de acordo com Marx

\begin{tabular}{|l|l|}
\hline Departamentos & $\begin{array}{l}\text { Departamento I: os meios de produção são produzidos: capital fixo } \\
\text { e capital circulante. } \\
\text { Departamento II: produção de artigos de consumo individual: ne- } \\
\text { cessidades e luxo. } \\
\text { Departamento III: produção de artigos para o consumo coletivo e } \\
\text { não produtivo: materiais militares. }\end{array}$ \\
\hline Setores & $\begin{array}{l}\text { Definidos pelo valor de uso imediato de seus produtos (automóveis, } \\
\text { construções, aparelhos eletrônicos, educação, etc.). a indústria auto- } \\
\text { mobilística produz em todos os setores: caminhões para o consumo } \\
\text { produtivo, carros para o consumo individual, carro para o consumo } \\
\text { individual coletivo e não produtivo (tanques de guerra). }\end{array}$ \\
\hline $\begin{array}{l}\text { Unidades } \\
\text { individuais de } \\
\text { propriedade }\end{array}$ & $\begin{array}{l}\text { Não está em função da divisão do trabalho; é imposta sobre o capital } \\
\text { social em acumulação, pelo sistema de relações de propriedades ex- } \\
\text { pressas e constituídas através do sistema legal predominante. }\end{array}$ \\
\hline
\end{tabular}

Fonte: Smith, 1988, p. 162.

Quanto à tendência para a igualização, Smith (1988) escreve que há uma dicotomia na produção do espaço geográfico. Ou seja, em escala mundial, o espaço é produzido como um espaço relativo, mas, internamente, o espaço geográfico se diferencia em espaços absolutos distintos em diferentes escalas. Essa diferenciação se dá mais no espaço da circulação, já que a burguesia tem necessidade de expandir o mercado para que possa distribuir seus produtos. Isso ocorre em escala global, pois é imperativo estabelecer-se em toda parte a fim de criar vínculos. A tendência para a igualização se dá em função das condições de produção e do nível de desenvolvimento das forças produtivas inerentes à produção global do espaço relativo. Para Marx e Engels, segundo o autor, essa tendência leva à aniquilação do espaço e do tempo.

A questão do espaço é bastante discutida através dos tempos e seu conceito muda à medida que mudam as relações dos homens entre si e dos homens com a natureza, através de sua apropriação. E o espaço sempre está atrelado ao tempo. Lipietz (1999) afirma que espaço e tempo são as maiores dimensões da vida humana e que possuem significado social. Para o autor, enquanto a maioria das teorias propõe o domínio do espaço pelo tempo, Castells propõe ser o espaço o organizador do tempo em uma sociedade em rede.

Se, no passado, o espaço era concebido como algo rígido, superfície, extensão, com as novas tecnologias, hoje, o espaço da economia, 
das comunicações, do poder não possui fronteiras no sentido de linhas demarcadas, como no conceito ratzeliano. O processo histórico que levou o mundo a essa situação foi o capitalismo. E o sistema de produção industrial foi o responsável pela perspectiva da expansão capitalista.

No final do século XIX a indústria tinha como seu maior sustentáculo a máquina a vapor. Quem definia todo o processo de acumulação era a força de trabalho. Marx denomina essa força de trabalho de maisvalia absoluta e mais-valia relativa. A mais-valia absoluta se constituía na exploração máxima da força de trabalho, representada pelo número de horas trabalhadas (jornada de trabalho). E chama de mais-valia relativa à produtividade estabelecida pelo exército de reserva, fenômeno que seria responsável pela mobilidade do trabalho. Para Marx, o que há não é a mobilidade de homens, mas a mobilidade do trabalho, como possibilidade de acumulação. Naquela época, a análise de Marx era sobre os departamentos que estavam em função de uma economia produtiva ligada ao capital eminentemente industrial.

O processo de colonização fez parte do jogo do circuito capitalista, como ocorreu com a acumulação primitiva do capital no processo de exploração da Índia, da China, do Brasil, entre outros. Nesse período, a configuração geográfica se repartiu em função dos poderes de controle de mercado. No final do século XIX e início do século XX já há o circuito completo do capital: produção, circulação, distribuição e consumo. É nesse momento que Ratzel apresenta o princípio da extensão, quando é criada a ideia de território, fundada no conceito de solo. Ao trabalhar o conceito de território, Ratzel se refere a uma questão de ocupação, de apropriação. Para ele, se a população tem a garantia desse território (solo), não terá problema de sobrevivência. A partir de Ratzel, portanto, território passa a ser uma categoria de análise. Nesse contexto, o que há é a formação de um regime de acumulação extensivo, cuja preocupação básica era a produção de bens de produção, de bens de capital, lastro para que se garantisse o aumento da produção. Essa relação mercantilista será exercida pelo Estado que, nessa época, tinha apenas uma força militar (gendarme) a fim de garantir a propriedade. Consolida-se, então, o conceito de Estado, compreendido como nação, garantia da autonomia do espaço vital. Território está, então, intrinsecamente ligado ao conceito de Estado-Nação. A partir de 1870, com a abolição da escravidão, estabelecese a garantia do mercado interno. Garantido o mercado interno, tem-se a garantia das fronteiras (abertas e rígidas ao mesmo tempo). No conceito de nação está implícita a garantia dos recursos (naturais, minerais) garantidos pela fronteira. 
Hoje, o conceito de território tem nitidamente o sentido de poder. Para Smith (1996), não é fácil definir quem exerce poder sobre a jurisdição territorial do Estado. De maneira geral, as teorias dizem que quem exerce esse poder é o Estado e seus órgãos. Para o autor, os desafios à soberania da Nação-Estado tanto têm origem em processos globais ("de cima”) como na sociedade civil, sob forma de ações coletivas, descentralizadas e baseadas na comunidade ("de baixo"). O destino das localidades hoje é cada vez menos determinado pela Nação-Estado e cada vez mais por decisões, atividades e eventos que se encontram além da jurisdição do Estado. Contudo, cada vez mais a Nação-Estado sofre desafios provindos das localidades sobre as quais ela reivindica soberania política.

É certo que a mais importante inovação tecnológica do capitalismo atual está no campo da informática e da eletrônica, com a criação dos computadores. No início da expansão capitalista a máquina substituiu a força humana. Hoje, o computador substitui as operações de cálculo cerebral, "Chegando a elaborar, com autêntico virtuosismo, 'decisões' derivadas das 'ordens’ que a máquina cérebro recebe” (CATANI, 1999, p. 50 ).

Essa "revolução técnico-científica" anuncia nova fase do capitalismo, e fica difícil de inferir até onde poderá chegar sua tendência para a concentração. Atualmente, o capitalismo é um capitalismo de empresas industriais gigantescas, presentes em toda parte, como um ente onipresente e disperso.

Hoje, o capitalismo não mais necessita do exército de reserva, que está sendo substituído de forma cada vez mais veloz pela tecnologia, principalmente a informática. Veja-se o que acontece com os serviços prestados pelos bancos. As máquinas para transferências de valores, para pagamentos, para consultas, substituem postos de trabalho. Sem falar nos computadores que, na tranquilidade das residências, fazem todo trabalho virtual que levaria horas em filas de bancos. Os computadores também substituem o trabalho feito pelo correio, através dos e-mails. Substituem as lojas, locais de escolha e compra de produtos. Substituem as livrarias, com seus mostruários de livros, colocando-os à venda nos portais da web. Substituem as bibliotecas, oferecendo livros e enciclopédias via internet ou mídias, ou e-books. Substituem o encontro físico das pessoas, através das redes sociais. Dessa forma, as fronteiras, os limites físicos foram derrubados. Vai-se a qualquer lugar sem sair do lugar. Escolhe-se e compra-se qualquer mercadoria sem tocar no produto. Paga-se qualquer valor sem tocar no dinheiro. Distribuem-se mensagens, apelos comerciais, religiosos, pornográficos, sem ter contato direto com as pessoas. Mas, afinal, isto é bom? É ruim? Seremos pessoas confinadas a quatro paredes, sozinhas, com medo de sair de casa, isoladas, sem saber o que é o afeto, o contato 
físico, o sorriso franco e aberto, as demonstrações de insegurança, medo, raiva, estupefação, indignação, sentimentos mais do que humanos?

Por outro lado, aparece a contradição. Quantos têm acesso a toda essa tecnologia? Muitos sequer conhecem uma televisão, uma geladeira, um aparelho de som, uma casa digna para morar. No entanto, todos sentem os efeitos desse mundo tecnificado, pois os que estão bem não têm tempo para rever a má distribuição das benesses da tecnologia. Ou seja: de outra forma, em outros tempos, os problemas continuam. As desigualdades que marcavam os suseranos e os servos, os príncipes e a plebe, os capitalistas e os proletários, estão mais presentes do que nunca no tempo e no espaço, hoje. 
REFERÊNCIAS

CASTELLS, M. A era da informação. São Paulo: Paz e Terra, 1999.

A sociedade em rede. Rio de Janeiro: Paz e Terra, 2002.

CATANI, A. M. O que é capitalismo? São Paulo: Brasiliense, 1999.

CHESNAIS, F. A mundialização do capital. São Paulo: Xamã, 1996.

DOWBOR, L. A reprodução social. Petrópolis, RJ: Vozes, 2002. V. 1.

HAESBAERT, R. Territórios alternativos. Niterói: EdUFF;

São Paulo: Contexto, 2002.

HARVEY, D. Los limites del capitalismo y la teoría marxista. México: Fondo de Cultura Económica, 1990.

IANNI, O. A era do globalismo. 3. ed. Rio de Janeiro: Civilização Brasileira, 1997.

JIMÉNEZ, J. M.; CANTERO, N. O. Paris: l'année sociologique III - el pensamiento geográfico. Madrid: Alianza Editorial, 1982. p. 1-14. Disponível em: <http://www.dhiernaux.docencia. terrageo.net>. Acesso em: 23 mar. 2014.

LIPIETZ, A. O capital e seu espaço. São Paulo: Nobel, 1988.

MAQUIAVEL, N. O príncipe. São Paulo: Saraiva, 2002.

RAFESTIN, C. Por uma Geografia do poder. São Paulo:

Ática, 1993.

RATZEL, F. El território, la sociedad y el Estado. In:

GÓMES MENDOZA, J.; 
SCHILLING, V. Confrontos: o pensamento político alemão. Porto Alegre: Editora da Universidade/UFRGS, 1996.

SHÄFER, N. Globalização e fronteira. In: CASTELLO, I. et al. (org.). Práticas de integração nas fronteiras: temas para o Mercosul. Porto Alegre: Editora da UFRGS; Instituto Goethe/ ICBA, 1995 .

SMITH, G. Teoria política e Geografia Humana. In: GREGOORY, D.; MARTIN, R.; SMITH, G. (org.). Geografia Humana: sociedade, espaço e ciência social. Rio de Janeiro: Zahar, 1996.

SMITH, N. Desenvolvimento desigual. Rio de Janeiro: Bertrand Brasil, 1988. 


\section{APLICAÇÃO DOS \\ CONCEITOS \\ GEOGRÁFICOS NO \\ ENSINO \\ FUNDAMENTAL E \\ MÉDIO}

\section{Gilmar Alves Trindade}

Alguns jovens licenciados em Geografia, quando já exercendo a prática pedagógica, costumam reclamar da dificuldade em instrumentalizar os conceitos básicos em seus planos de ensino, especialmente no nível fundamental II. Podemos fazer alguns questionamentos e reflexões em torno desse problema, tais como:

1. Por que tanta dificuldade, se o mapa curricular da Licenciatura em Geografia contempla a disciplina Conceitos Básicos da Geografia, na qual, necessariamente, essa aplicação deve ser estimulada?

2. Por que esses professores, quando ainda graduandos, no período do estágio em ensino fundamental e médio não levam essas dificuldades para serem trabalhadas em sala de aula, na universidade, com seus professores de Estágio Curricular?

3. O que justificaria essa dificuldade, posto que, ao longo dos 4,5 anos de estudos no curso de Licenciatura em Geografia, diferentes disciplinas devem abordar essa articulação entre os conceitos básicos e sua instrumentalização na educação básica?

4. Essas abordagens estão de fato sendo realizadas no interior das diferentes disciplinas do curso de Geografia, ou apenas naquela denominada Conceitos Básicos?

Devemos refletir sobre o tipo de profissional em Geografia que somos e o tipo de profissional em Geografia que estamos colocando no mercado de trabalho, especificamente na área de ensino na educação básica. Ao mesmo tempo, precisamos inserir essas inquietações no bojo da educação brasileira na sua totalidade, pois, os últimos indicadores que avaliam o 
nível dos egressos no ensino médio apontam fortes deficiências quanto às noções elementares da Matemática e graves problemas relacionados à aprendizagem da Língua Portuguesa, principalmente quanto à leitura, interpretação e escrita de textos. Defasagens essas que irão comprometer profundamente o nível de aprendizagem e a qualidade do ensino nos diferentes cursos no nível superior, inclusive os de formação de professores.

A área da Geografia, no ensino superior, exige algumas competências ou pré-requisitos dos alunos que ingressam neste curso, como noções básicas de matemática, alfabetização cartográfica e geográfica, noções essenciais para manuseio de computadores e noções básicas de inglês; além, evidentemente, de saber ler, interpretar e escrever textos em língua portuguesa. Assim, o questionamento fundante de todos os outros passa a ser: esses alunos, ingressos recentemente no curso de Geografia, quando iniciam seus estudos no primeiro semestre trazem do ensino médio essas competências?

Dessa maneira, vê-se que os problemas que os professores egressos da universidade encontram quando assumem suas salas de aula têm raízes bastante profundas, complexas e de difícil solução; pois, estão relacionados ao contexto atual da educação pública brasileira e às decisões políticas que, apesar de estarem garantindo o acesso amplo dos jovens à educação básica, não têm promovido ações concretas que levem à melhoria do nível do ensino e da aprendizagem desses alunos. Isso está sendo percebido de forma contundente na universidade.

Acontece que os jovens egressos do ensino médio estão sendo aprovados nos cursos superiores em diferentes áreas, mesmo com todas aquelas dificuldades apontadas anteriormente. Os responsáveis pelas atuais políticas educacionais que instituíram o Exame Nacional do Ensino Médio (ENEM), o Sistema de Seleção Unificado (SISU) e a política de cotas raciais não estão conseguindo detectar essas deficiências - e, provavelmente, para o Estado, não seja mesmo conveniente fazê-lo - caso contrário, parte significativa dos alunos, hoje matriculados no curso superior, seria reprovada.

Voltemos agora à problemática que me levou à reflexão inicial, qual seja: muitos dos professores da disciplina Geografia no ensino fundamental II - e, certamente, no ensino médio também - estão encontrando dificuldades em fazer uso dos conceitos básicos da Geografia nos planos de ensino da disciplina.

Em primeiro lugar é preciso lembrar que não se ensinam os conceitos básicos (espaço, lugar, paisagem, região e território) em sala de aula, mas, sim, instrumentalizam-se esses conceitos associados a diferentes conteúdos que serão estudados naquele curso, naquela unidade ou naquela aula. Portanto, não se ensinam os conceitos, mas, com os conceitos. 
A preocupação com a dimensão teórico-conceitual na representação do que de fato existe na realidade se explica pela necessidade de se aproximar ao máximo dessa realidade que os conceitos buscam explicar, pois:

\begin{abstract}
Qualquer conceito reflete aquilo que é essencial, os aspectos essenciais, as relações essenciais, enfim, a essência do objeto, fenômeno ou processo. Portanto, a construção de um conceito exige um exercício de captura do que é essencial para sua formulação e, nesse sentido, reflete um certo grau de generalização. Assim, o conceito é sempre uma simplificação do real e ao mesmo tempo uma generalização deste (LENCIONI, 2011, p. 81-82).
\end{abstract}

Portanto, como representação do real que se transforma continuamente, o conceito nos ajuda a compreender, a assimilar a realidade ou um fenômeno qualquer. No caso da Geografia, os conceitos devem nos aproximar ao máximo das relações socioespaciais que concretamente coexistem ao longo do processo dinâmico, complexo, contraditório e contínuo de produção do espaço geográfico. Os conceitos são formulados para explicar fenômenos e situações que existem, de fato, na realidade. $\mathrm{O}$ uso dos conceitos, de forma contextualizada, dá mais clareza àquilo que se pretende explicar. A instrumentalização de conceitos e categorias científicas é imprescindível na construção do conhecimento nas diferentes áreas. Por isso existe nos mapas curriculares de diferentes cursos um espaço indispensável para as disciplinas vinculadas às questões epistemológicas (TRINDADE, 2010).

Assim, um professor de Geografia no ensino fundamental II deve levar seu aluno a compreender, ainda que gradativa e simplificadamente, como se dá o processo de produção do espaço, quais interações envolvem, quais agentes participam e em quais escalas; e, ainda, como ele, aluno, participa ou se relaciona com esse processo. Nesse sentido, os conceitos de espaço, lugar, território, paisagem e região ajudam no processo de ensino/aprendizagem dessas relações socioespaciais.

Acredito que um exemplo ilustrativo de um estudo de questões do lugar e da região, através da paisagem urbana e no âmbito do processo de produção do espaço baiano pode ajudar a esclarecer o que essa minha discussão encerra.

O Recôncavo Baiano é uma região com identidade bastante expressi$\mathrm{va}^{1}$, construída ao longo do processo de ocupação e formação dos territórios

\footnotetext{
Ainda que essa identidade tenha sido construída ao longo do tempo como resultado de dissensos entre o colonizador português, os negros trazidos da África para o trabalho forçado e os indígenas, habitantes nativos desse território.
} 
baiano e brasileiro. Inserida como área de expansão dos interesses colonialistas de Portugal no território brasileiro a partir do século XVI, a região se desenvolve economicamente voltada para a produção e exportação de cana-de-açúcar para a metrópole portuguesa, entre os séculos XVII e XVIII; posteriormente, após o declínio da atividade canavieira, acontece também a exploração do fumo no século XIX.

O trabalho na lavoura da cana-de-açúcar envolveu mão de obra majoritariamente escrava africana, o que explica, atualmente, o grande contingente de população negra nos municípios da região. Essa concentração de atividades produtivas no período colonial e a proximidade geográfica com a capital da colônia, Salvador, estimularam a urbanização e a instalação de fixos, como porto e estrada de ferro, que construíram a rede de fluxos regionais do Recôncavo Baiano. Nesse contexto histórico-geográfico, aglomerados populacionais surgiram e se desenvolveram, dando assim origem ao processo de formação de uma rede urbana em que se destacaram cidades como Nazaré, Santo Amaro, Cachoeira e São Félix (FIGURA 1).

FIGURA 1 - Paisagem da cidade de São Félix, às margens do rio Paraguaçu

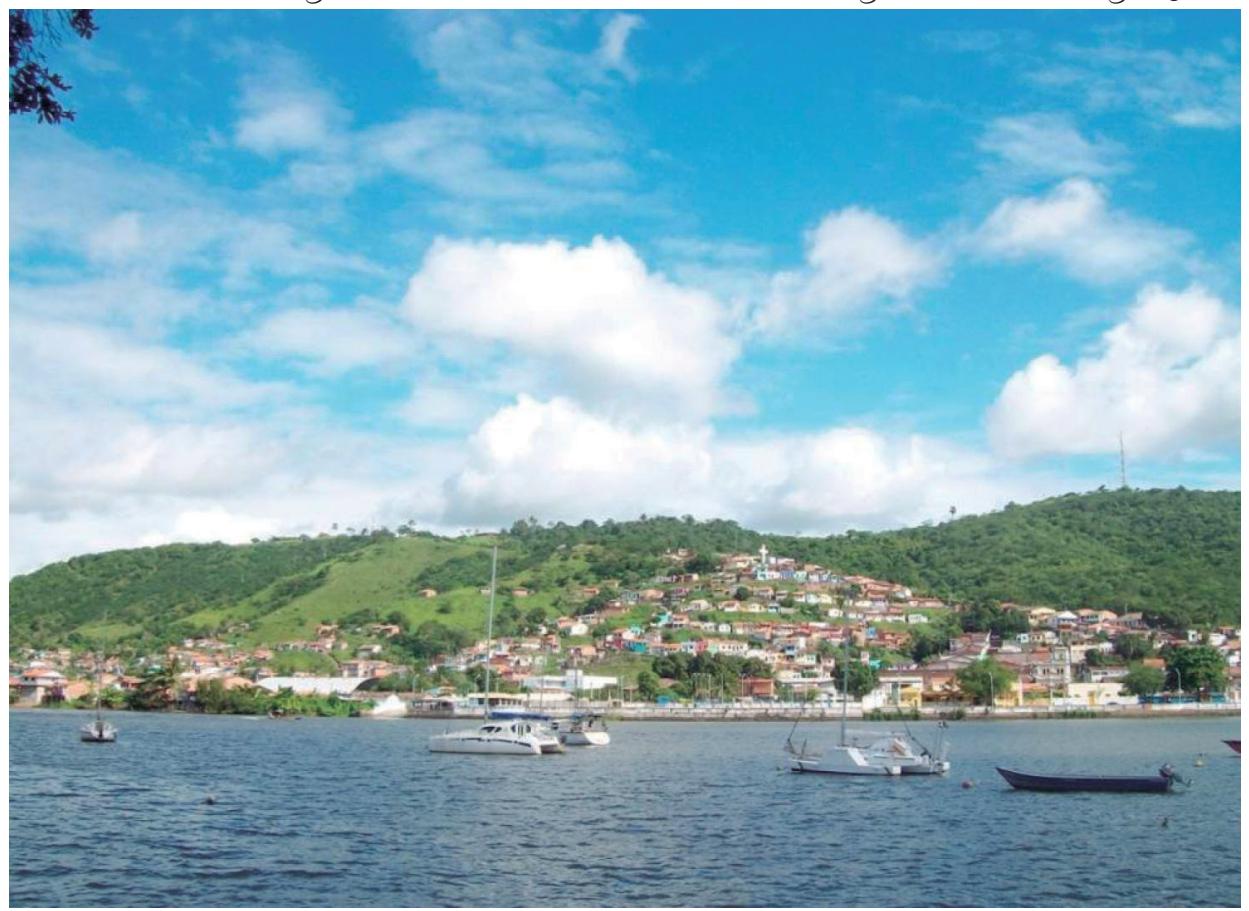

Fonte: Gilmar Alves Trindade, 2014. 
Assim, observam-se nesta paisagem de São Félix elementos naturais (o rio, a vegetação, o relevo) e objetos culturais (as casas, as embarcações, uma cruz). A paisagem é um dos conceitos mais importantes da Geografia, resguardadas temporalidades e espacialidades diversas. A paisagem não é estática, imóvel, como nos ensinou Santos (1996); ela é feita também de cores, sons, odores e atende ao movimento da sociedade ao longo do processo de produção do espaço; ou seja, a sociedade transforma continuamente o espaço e as marcas desse processo ininterrupto ficam registradas na paisagem; ela resguarda, assim, elementos do passado e do presente, e já denuncia as possíveis mudanças rumo a um futuro próximo - o dia seguinte; ou distante - daqui a meses, anos, décadas. A montagem dos equipamentos e adereços para a festa de São João prenuncia o movimento frenético e os densos fluxos que acontecerão naquele espaço dentro de alguns dias (FIGURAS 2 E 3). A paisagem pode revelar o que está por vir.

FIGURA 2 - Montagem da estrutura para a festa de São João em Cachoeira, Bahia

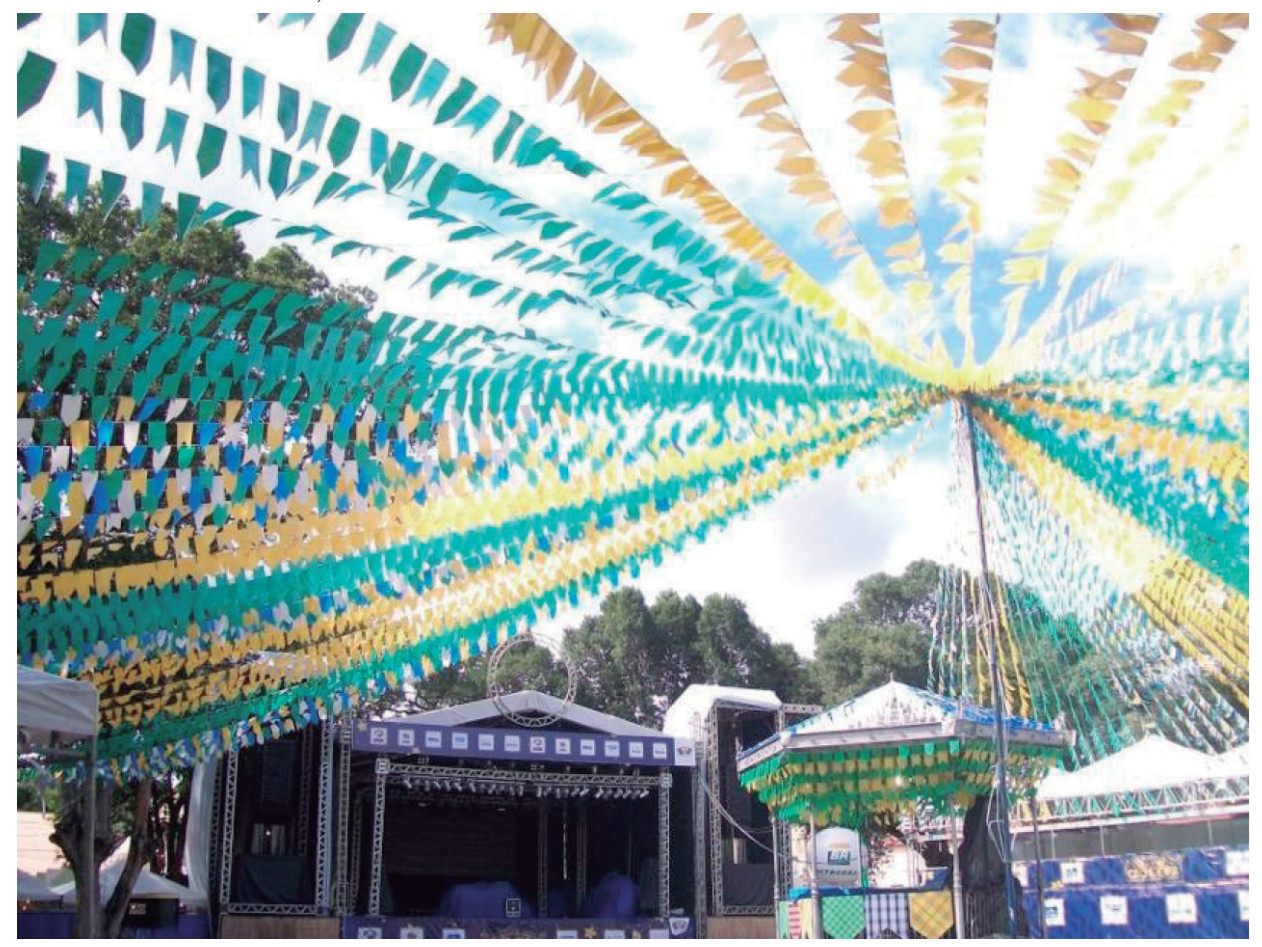

Fonte: Gilmar Alves Trindade, 2014 
FIGURA 3 - Fluxo de pessoas no dia de São João, em Cachoeira, Bahia

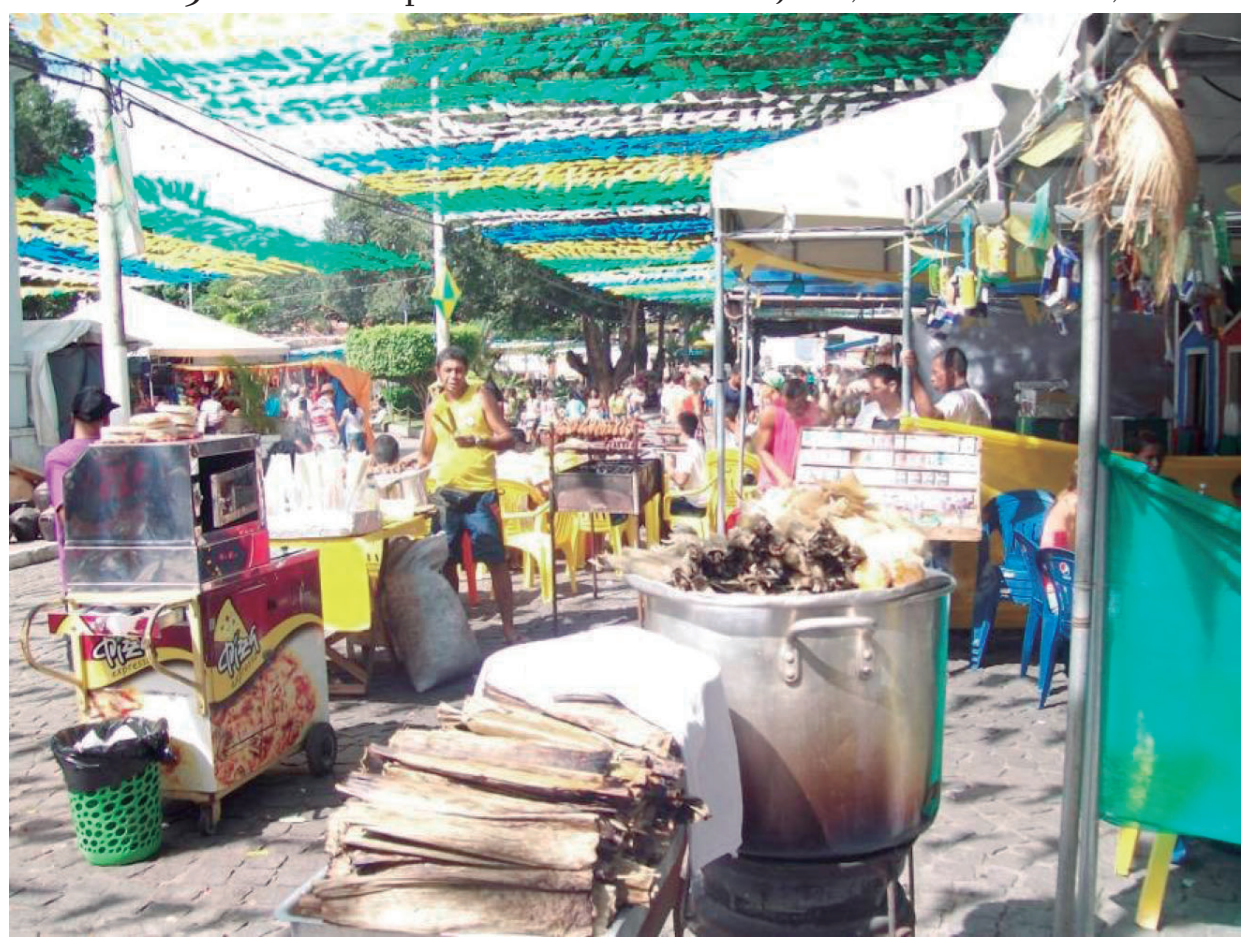

Fonte: Gilmar Alves Trindade, 2014.

Um professor de Geografia no ensino fundamental pode perfeitamente iniciar os estudos com seus alunos, questionando o que existe por trás da paisagem, o que está subjacente a ela, o que explica, afinal, essa paisagem da FIGURA 1? Como se constituiu? Quando se iniciou a transformação da paisagem natural em paisagem geográfica, humanizada, cultural? Quais agentes e ações estão envolvidas nesse processo? O que fez surgir a cidade de São Félix? Quais redes e fluxos existiram no período colonial? Para quê? Desapareceram? Transformaram-se? O lugar ainda guarda elementos do período colonial? Quais? Como se articulam com o tempo presente? O que aquela cruz ao alto, na paisagem, representa? Qual a função do rio Paraguaçu no período colonial? Qual a sua função, atualmente? Como a cidade e o município de São Félix se inserem na região do Recôncavo Sul, no estado da Bahia, no Brasil? Quais articulações o lugar estabelece com o mundo? Qual lugar o aluno ocupa nessa paisagem, onde mora, quais caminhos percorre?

Entendo que um professor de Geografia no ensino fundamental ou médio tem a seu alcance inúmeras possibilidades de estimular a construção do conhecimento de seus alunos. Através de um recorte da paisagem 
do lugar onde a escola funciona o professor pode criar diversas metodologias para o estudo desse lugar com as interações temporais e espaciais que o mesmo resguarda. No âmbito desses estudos que se estendem por meses (um ano letivo) ou por anos (do $6^{\circ}$ ao $9^{\circ}$ ano), o aluno vai, gradativamente, construindo e ampliando seu conhecimento via mediação do professor; o aluno começa fazendo uso de termos do senso comum e vai, aos poucos, sendo apresentado ao conhecimento científico. É nesse momento que ele passa a compreender o sentido dos conceitos: quando faz uso de um conceito como lugar ou região para expressar concretamente algo que aprendeu em sala de aula e em sua vida cotidiana.

Lugar, território, paisagem e região vão, aos poucos, deixando de ser meras abstrações em seu pensamento, e o aluno passa a compreender o que, de fato, quer expressar quando utiliza um desses conceitos; porque, enfim, o conceito passou a representar de forma mais aproximada o que ele efetivamente experiencia em seu cotidiano, em sua vida. A Geografia, assim, passa a ter sentido no currículo escolar e na vida dos alunos.

O exemplo ilustrativo que dei fazendo uso de uma paisagem da cidade de São Félix pode ser adaptado para qualquer outra cidade ou lugar. Os conceitos foram utilizados para indicar a possibilidade de produção de metodologias e recursos didático-pedagógicos no ensino de Geografia. O professor não precisa, a priori, solicitar aos alunos que definam o que é uma paisagem ou um território e cobrar isso em uma avaliação. A compreensão acerca dos significados dos conceitos - porque existem vários para cada conceito - emergirão ao longo do processo de ensino/aprendizagem em uma turma que esteja trabalhando com a disciplina Geografia. A função do professor é intermediar esse processo e propor atividades e questionamentos significativos que ajudem os alunos a apreenderem conteúdos geográficos com uso dos conceitos.

Entretanto, antes disso, o próprio professor de Geografia é quem precisa ter uma consistência de conhecimentos geográficos - inclusive conceituais -, domínio de conteúdos, articulação teoria/prática e autonomia intelectual que lhe credenciem a formular planos de estudo e metodologias de fato significativas, que auxiliem os alunos a compreenderem a importância dos estudos dessa disciplina e seu sentido no currículo escolar e em suas próprias vidas.

Entendo, finalmente, que antes de o professor de Geografia estimular a demanda de habilidades e competências de seus alunos neste campo disciplinar, precisa, ele próprio, ampliar e consolidar as suas próprias competências. Isso se dá ao longo de seu processo de formação como licenciando em Geografia, na universidade, e se consolida ao longo do tempo, na esfera do trabalho e da vida, pois, um professor, em qualquer nível de ensino, jamais deixa de estudar, jamais abandona seu espírito inquieto de pesquisador. 


\section{REFERÊNCIAS}

LENCIONI, S. Algumas observações sobre a construção de conceitos e os conceitos de cidade e urbano. In: SAQUET, M. A. et. al. (org.). Territorialidades e diversidade nos campos e nas cidades latino-americanas e francesas. São Paulo: Outras Expressões, 2011. p. 79-98.

SANTOS, M. Metamorfoses do espaço habitado. 4. ed. São Paulo: Hucitec, 1996.

TRINDADE, G. Tendência(s) das monografias do curso de Licenciatura em Geografia. Revista R'AEGA, Curitiba, n. 20, p. $143-156,2010$. 


\section{OS PROFESSORES \\ DE GEOGRAFIA \\ ENSINANDO A \\ PESQUISAR NA ESCOLA}

\section{Rita Jaqueline Nogueira Chiapetti}

A última frase do texto do professor Gilmar será a minha primeira frase: "[...] um professor, em qualquer nível de ensino, jamais deixa de estudar, jamais abandona seu espírito inquieto de pesquisador”, ou seja, todo pesquisador é inquieto, curioso, cheio de dúvidas, de perguntas... Portanto, todo professor deve ser um pesquisador, no sentido da curiosidade, de fazer perguntas, de procurar, de pensar, de refletir, de buscar continuamente o saber.

Bem sei que para pesquisar é preciso conhecimento sobre pesquisa, tempo, criatividade e condições materiais (biblioteca, computador com acesso à internet, etc.), mas também sei que é imprescindível que o professor do ensino fundamental e do médio tenha o hábito de pesquisar, para que na sua prática não reproduza somente o livro didático, ou não seja meramente um professor transmissor ou repassador de informação ou, ainda, seja um simples usuário do produto do conhecimento científico.

Para Demo (1996, p. 14) é preciso desmistificar a pesquisa, no sentido da separação do ensino e da pesquisa, pois,

Quem ensina carece pesquisar; quem pesquisa carece ensinar. Professor que apenas ensina jamais o foi. [Professor] -Pesquisador que só pesquisa é elitista explorador, privilegiado e acomodado.

Pois bem, o que é pesquisa, então? E pesquisa escolar? A pesquisa escolar é diferente da pesquisa científica? É necessário planejar a pesquisa escolar? É possível ensinar os alunos a fazerem pesquisa escolar? A pesquisa escolar pode ser uma metodologia de ensino de Geografia? Pode-se aprender Geografia com pesquisa escolar? Como pode ser feita a avaliação, no caso do ensino de Geografia através da pesquisa?

São tantas as questões! Algumas podem ser respondidas, pesquisando-se; outras na prática, ensinando... Nesse texto não tenho a intenção de responder a todas essas perguntas, mas gostaria que elas fossem um incen- 
tivo, para aqueles professores que o lerem, ficarem curiosos e procurarem as respostas pesquisando... e ensinando seus alunos a pesquisar na escola.

Conforme Marcos Bagno, professor e escritor de uma obra dedicada aos professores a respeito do que é e como se faz pesquisa na escola, pesquisa é uma palavra que veio do espanhol, o qual a herdou do latim, do verbo perquiro, que significa: "Procurar; buscar com cuidado; procurar por toda parte; informar-se; inquirir; perguntar; indagar bem; aprofundar na busca" (BAGNO, 2001, p. 17).

Então, quando se pesquisa se está sempre buscando algo, mesmo que seja alguma coisa do cotidiano, como, por exemplo, algum programa na TV ou um jogo grátis para baixar da internet. Mas, não é a esse tipo de pesquisa que vou me referir nesse texto, e, sim, àquela pesquisa que pode ser ensinada/feita na escola (pesquisa escolar), para que os alunos construam seu conhecimento e aprendam, nesse caso, Geografia.

Demo (1998, p. 78) afirma que, "A rigor, ensinar é algo decorrente da pesquisa". Por isso, na universidade, os professores fazem pesquisa (ou deveriam fazer). Mas, nesse nível de ensino se faz pesquisa científica, a qual é uma construção técnica do conhecimento, sendo que ela é, ao mesmo tempo,

Princípio científico e educativo. Sem pesquisa, não há vida acadêmica, a menos que a reduzamos a uma tática incolor de repasse copiado (DEMO, 1998, p. 78).

Minayo (1993), dentro de um cunho mais filosófico, considera a pesquisa como atividade básica das ciências na sua indagação e descoberta da realidade. A autora escreve, também, que a pesquisa é uma atitude e uma prática teórica de constante busca, que define um processo intrinsecamente inacabado, permanente e que nunca se esgota. A pesquisa é, portanto, uma atividade que busca a aproximação com a realidade, além de combinar teoria e dados.

No contexto da educação básica, os professores também podem ser pesquisadores e ensinar seus alunos a fazerem pesquisa escolar (ou deveriam ensinar), segundo Demo (1998), como princípio educativo ou um modo de educar, de ensinar. O professor deve ser um profissional da educação pela pesquisa, desenvolvendo a capacidade do aluno pesquisar.

A pesquisa escolar tem a mesma importância da pesquisa científica, pois vai contribuir na promoção da autonomia do aluno, tornando-o capaz de: desenvolver sua criticidade e curiosidade; aprender a fazer perguntas e de refletir sobre elas; selecionar as informações relevantes à sua pesquisa; 
refletir sobre os resultados obtidos pela pesquisa; compreender os conceitos envolvidos na pesquisa; etc.

Cabe enfatizar que a pesquisa está proposta nos Parâmetros Curriculares Nacionais (PCN) de todas as disciplinas do currículo do ensino fundamental e do médio. Naquele documento lê-se:

Considerando a formação mais ampla dos alunos e a importância de desenvolverem atitudes de autonomia em relação aos seus estudos e pesquisas, é necessário que o professor, por meio de rotinas, atividades e práticas, os ensine como dominar procedimentos que envolvam questionamentos, reflexões, análises, pesquisas, interpretações, comparações, confrontamentos e organização de conteúdos. Nesse sentido, o professor deve considerar, cotidianamente, a participação dos alunos nas decisões dos encaminhamentos das diferentes atividades [...] (BRASIL, 2000, p. 76).

Portanto, verifica-se a importância da pesquisa escolar como um método de ensino mais amplo, com a participação dos alunos em diferentes atividades, o que pode ser alcançado com a prática da pesquisa. O professor mediará o percurso da pesquisa, propiciando momentos para os alunos questionarem, auxiliando-os na elaboração de argumento crítico a partir do aprendizado que eles próprios irão buscar.

Utilizar a pesquisa como metodologia de ensino, segundo Martins (2005, p. 37):

É criar condições para que o estudante mostre os saberes prévios que possui sobre o assunto a ser investigado, como também é lhe dar oportunidade de se mobilizar na busca e na construção de conhecimentos novos, exercitando, para isso, a desenvoltura, a criatividade e as próprias competências na utilização dos procedimentos do método científico pelo crescimento de sua autoestima e confiança.

Para Inácio Filho e Nunes (1999), a finalidade da pesquisa escolar é a de ampliar e enriquecer o conhecimento dos alunos. Contudo, para que isso aconteça, é preciso desmistificar a pesquisa escolar e pontuar algumas orientações necessárias a serem conduzidas em sala de aula ou fora dela, visto que, ao utilizá-la como metodologia de ensino, os professores precisam, antes de tudo, saber fazê-la e ter a clareza de que pesquisar não é uma atividade fácil para os alunos, os quais podem acabar fazendo somente cópia dos textos consultados em livros ou sites da internet. 
Sobre objetivos da pesquisa escolar, Antonio (2010) cita objetivos bastante amplos que podem ser alcançados através da sua prática:

- Desenvolver atitudes autônomas de busca de informações.

- Desenvolver a habilidade de usar diferentes meios de pesquisa (livros, revistas, entrevistas, observações, internet, etc.).

- Desenvolver a habilidade de leitura e interpretação de textos.

- Expandir o universo textual dos alunos, colocando-os diante de diferentes formas de linguagem (textos com diversas formas de linguagem, figuras, gráficos, ilustrações, imagens, filmes, etc.).

- Desenvolver a capacidade de análise e síntese das informações (respeitado o nível de desenvolvimento cognitivo e faixa etária dos alunos).

- Desenvolver habilidades artísticas relativas à apresentação gráfica dos trabalhos de pesquisa produzidos, fazendo uso de imagens e ilustrações diversas, bem como de programas e instrumentos de produção artística.

- Desenvolver a habilidade de escrita, reescrita e produção textual.

- Desenvolver habilidades de comunicação, ao apresentar a pesquisa.

- Desenvolver habilidades de trabalho colaborativo (pesquisando-se em grupos e contando com o apoio do professor).

Pode-se ensinar a fazer pesquisa escolar em todo o ensino fundamental e no médio, entretanto, é imprescindível que, mesmo que o professor saiba fazer pesquisa, por isso pode ensinar a fazê-la, não perca sua ânsia de sempre aprender, sobretudo de aprender interagindo com os alunos, pois, segundo Freire (1996, p. 23): "Não há docência sem discência, as duas... quem ensina aprende ao ensinar e quem aprende ensina ao aprender". Para esse autor, a capacidade de o professor aprender com o aluno faz parte de uma relação democrática e, por isso mesmo, pedagógica.

Para Pontuschka; Paganelli e Cacete (2007, p. 98), "Ensinar a pesquisar requer criar situações e condições didáticas que estimulem a curiosidade e a criatividade" dos alunos. Se a escola tiver uma boa biblioteca ou uma sala contendo computadores com acesso à internet, isso se torna mais fácil. Mas, se a escola não oferecer condições adequadas para os alunos pesquisarem, o professor precisa, ele mesmo, ser criativo e preparar o material de pesquisa a ser utilizado em sala de aula ou levado para casa.

A perspectiva de trabalhar com o ensino da pesquisa na disciplina de Geografia, ou com a pesquisa como metodologia no ensino fundamental e no médio, 
Pressupõe uma mudança de atitude perante o conhecimento. Significa ultrapassar a visão da prática pedagógica como simples transmissão de um conhecimento pronto e acabado [...] (PONTUSCHKA; PAGANELLI; CACETE, 2007, p. 96).

No entanto, para ensinar Geografia através da pesquisa, o professor precisa ter aprendido na universidade e deve ser capaz de dominar a habilidade de produzi-la.

Para Callai, Helena e Callai, Jaemes (1998, p. 62), "O aluno tem que ser considerado em sua plenitude e não apenas como uma criança que está à disposição do professor e da escola para ser ensinado". Por isso ele deve ser visto como um cidadão que vive em sociedade. Nesse sentido, a aprendizagem pela pesquisa pode ser uma metodologia de ensino que contribui para que os alunos sejam verdadeiros cidadãos, já que podem construir seu próprio conhecimento e intervir na realidade do mundo. Se o professor de Geografia assim o fizer, ou seja, se der a chance de seus alunos se descobrirem enquanto cidadãos por meio da pesquisa, além de superar as formas convencionais de ensino, ele estará, de fato, ensinando Geografia, aquela que, "[...] afinal de contas, está em toda parte" (COSGROVE, 2004, p. 96).

Se a Geografia está em toda parte, ou se aprender Geografia é conhecer o mundo, compreendendo porque ele é assim e não de outra forma, o ensino da Geografia, de acordo com os PCN, deve oferecer:

\begin{abstract}
Instrumentos essenciais para compreensão e intervenção na realidade social. Por meio dela [Geografia] podemos compreender como diferentes sociedades interagem com a natureza na construção do seu espaço, as singularidades do lugar em que vivemos, o que o diferencia e o aproxima de outros lugares e, assim, adquirirmos uma consciência maior dos vínculos afetivos e de identidade que estabelecemos com ele. Também podemos conhecer as múltiplas relações de um lugar com outros lugares, distantes no tempo e no espaço, e perceber as marcas do passado no presente (BRASIL, 2000, p. 99).
\end{abstract}

Assim, na disciplina de Geografia os alunos devem ter a capacidade de identificar e refletir sobre diferentes aspectos da realidade do mundo, compreendendo a relação sociedade-natureza. Os PCN, por sua vez, referem-se aos professores de Geografia, os quais devem envolver, em sua prática,

Procedimentos de problematização, observação, registro, descrição, documentação, representação e pesquisa dos 
fenômenos sociais, culturais ou naturais que compõem a paisagem e o espaço geográfico [...] (BRASIL, 2000, p. 115).

Esses procedimentos podem ser cumpridos ou alcançados via pesquisa, já que, no ensino da pesquisa escolar, o professor de Geografia pode trabalhar qualquer assunto geográfico através da sua problematização, observação, etc.

A pesquisa escolar, então, é um método de ensino que pode ser aplicado no ensino de Geografia. Mas, como se trata de ensinar a pesquisar, necessariamente, além de a aula ser planejada (plano de ensino), a pesquisa também deve ser, ou seja, deve-se planejar a pesquisa, ou ensinar a partir do ensino de um projeto de pesquisa, já que ele é uma etapa imprescindível, ou o primeiro passo para a realização de uma pesquisa.

Contudo, esse projeto não é o mesmo da pesquisa na universidade, já que precisa ser adaptado ao ano escolar e à faixa etária dos alunos. O professor deve iniciar a aula sobre pesquisa escolar em Geografia explicando sobre o planejamento de uma pesquisa. Com este planejamento os alunos devem aprender sobre a importância de se planejar uma pesquisa, antes de desenvolvê-la. O professor pode falar, por exemplo, do dia a dia dos alunos, quanto aos seus estudos diários, enfatizando a importância de "planejarem" o horário, onde e como farão a tarefa (ou para casa), a revisão das aulas, etc.

Mas, o que é planejar uma pesquisa? Planejar uma pesquisa significa antever suas etapas, refletindo sobre ela, mesmo antes de iniciá-la. Então, elaborar seu planejamento é escrever sobre cada etapa da pesquisa, sobre tudo o que é necessário pensar antes de começar, de fato, a fazê-la, ou seja, deve-se elaborar um projeto.

Todo projeto de pesquisa deve ter um tema/assunto a ser abordado. No caso da pesquisa escolar em Geografia, esse assunto deverá ser um conteúdo da disciplina que os alunos irão aprender através da pesquisa.

É importante que o professor de Geografia inicie esta aula com a participação dos alunos, desde a escolha do assunto/conteúdo geográfico e a discussão da importância de saber pesquisar, passando por todas as suas etapas. O professor, como mediador da aprendizagem, deve instigar os alunos com perguntas que os ajudem a pensar sobre aquele assunto geográfico escolhido, até que cheguem à formulação do problema ou à principal pergunta sobre a qual a pesquisa deverá se desenvolver. Esse é o primeiro item do projeto de pesquisa. 
Assim, o professor vai mediando a construção coletiva de um projeto de pesquisa em Geografia. Essa construção pode envolver a turma toda (mediada pelo professor), construindo-se um único projeto, ou pode ser feita em grupos de alunos, construindo-se dois ou mais projetos ou, ainda, individualmente, construindo-se muitos projetos. Essa decisão deve ser do próprio professor, devido ao ano escolar envolvido, ao perfil e às características de cada turma. Entretanto, na primeira vez que o professor adotar essa metodologia é aconselhável que seja elaborado somente um projeto e que o próprio professor escreva no quadro item por item, para os alunos os copiarem em seus cadernos.

Quero enfatizar aos professores que essas aulas de Geografia através da pesquisa devem ser planejadas como qualquer outra, utilizando a metodologia e os recursos de ensino que considerarem necessários. Quanto ao tempo ou as aulas necessárias para alcançar êxito com relação ao aprendizado dos alunos, isso dependerá do ano escolar envolvido, da característica de cada turma e, principalmente, da metodologia de pesquisa definida para o assunto/conteúdo a ser pesquisado.

De certa maneira, o projeto da pesquisa elaborado na escola trará alguns elementos comuns de um projeto desenvolvido na universidade, quais sejam: O que pesquisar? Qual é a principal pergunta/questão da pesquisa? Para que ou por que pesquisar? O que se quer fazer ou alcançar com a pesquisa? Como será feita a pesquisa? Onde pesquisar?

Em outras palavras:

- O que pesquisar: escolha do assunto/conteúdo a ser pesquisado pelos alunos, ou seja, o tema da pesquisa. De acordo com o ano escolar, o professor deve selecionar assuntos do conteúdo da Geografia que os alunos devem aprender, e junto com eles escolher aquele mais votado ou aquele que eles próprios demonstraram maior interesse em aprender.

- Questão ou pergunta principal da pesquisa: definição do problema da pesquisa (dentro do assunto/conteúdo geográfico escolhido). Esse é o primeiro item do projeto de pesquisa, já que toda pesquisa sempre se inicia com um questionamento. Essa pergunta vai nortear o desenvolvimento da pesquisa, pois os alunos terão que respondê-la ou, pelo menos, procurar/encontrar respostas para ela, pesquisando.

- Justificativa da pesquisa: esse item deve explicar por que tal assunto/ conteúdo geográfico foi escolhido ou qual é a sua importância dentro do contexto em que os alunos vêm estudando Geografia; além de explicar por que os alunos devem aprender sobre esse assunto. 
- Objetivos da pesquisa: são as ações da pesquisa, o que se quer fazer ou o que se quer alcançar com ela. Pode-se criar um (principal ou geral) ou mais objetivos (específicos), mas o objetivo principal deve sempre estar de acordo com o problema, pois, afinal, ele é a ação a ser cumprida para se responder a pergunta inicial.

- Metodologia da pesquisa: esse item deve explicar como a pesquisa deverá ser feita pelos alunos. Por exemplo: através de leituras de livros, revistas, documentos, através da busca em sites confiáveis da internet; através da aplicação de entrevista ou questionário a algumas pessoas, através da análise de fotografias, de desenhos, de imagens de paisagens; através da observação da realidade, etc. Como em uma pesquisa a metodologia é sempre uma etapa muito importante, o professor terá que explicá-la com muito esmero, definindo a mais adequada à maturidade de seus alunos, para que o aprendizado aconteça de forma mais leve e prazerosa, já que uma pesquisa sempre é uma atividade que requer mais trabalho, portanto, mais tempo e empenho dos alunos. Na metodologia também se deve explicitar o tempo que os alunos levarão para desenvolver a pesquisa, se ela ocorrerá em sala de aula, na biblioteca da escola (se tiver), na sala de informática (se a pesquisa necessitar de internet), ou se os alunos a farão em casa ou em outro lugar que não seja a escola. Dentro da metodologia definida se pode incluir a participação de pessoas (chamados de sujeitos da pesquisa). Nesse caso, o instrumento de coleta das informações (questionário, por exemplo) deverá ser elaborado em sala de aula, orientado pelo professor, para que possa auxiliar os alunos na elaboração das perguntas, pois só deve ser perguntado o que for necessário sobre o assunto que se está pesquisando, e utilizando-se de linguagem adequada aos sujeitos participantes da pesquisa.

- Onde pesquisar, ou onde buscar conhecimento sobre o assunto/conteúdo geográfico a ser pesquisado: é a descrição das fontes em que os alunos deverão pesquisar: livros, revistas, textos, documentos, imagens, sites da internet ou qualquer outro material de pesquisa. Na pesquisa escolar é necessário que o professor forneça essas fontes (bibliografia) ou dê suas referências (a depender da idade dos alunos) e discuta a necessidade de sempre registrar as fontes consultadas para desenvolver qualquer trabalho de pesquisa, em qualquer nível de ensino.

- Como última etapa do projeto de pesquisa, deve-se dar um título para ele. Geralmente, os alunos são sempre muito criativos quando o professor pede que criem um título para o assunto a ser pesquisado. 
Um projeto de pesquisa na escola não deve ultrapassar duas páginas. Cada item ocupará, portanto, poucas linhas, pois o importante não é o seu tamanho, mas sim que os alunos aprendam sobre a necessidade de planejar uma pesquisa, já que essa etapa é tão importante quanto a própria pesquisa que, se bem planejada, ficará fácil de ser desenvolvida, e ainda que eles, como alunos-pesquisadores, sejam autores principais nesse processo de aprender a fazer pesquisa escolar e construam seu próprio conhecimento geográfico, desenvolvendo autonomia e criatividade em seus estudos escolares.

Depois de cumprida essa importante etapa, a da elaboração do projeto de pesquisa, os alunos tomam consciência de que pesquisar pode ser prazeroso, mas para isso precisam se envolver, dedicar-se, ler muito e ser criativos; só assim o professor pode passar para a etapa da aplicação do projeto de pesquisa, ou seja, a do desenvolvimento da pesquisa que foi planejada. Nesta nova etapa os alunos entenderão a importância do projeto de pesquisa, pois agora terão que "seguir" esse projeto para desenvolverem a pesquisa. É importante que, sempre que os alunos tiverem qualquer dúvida, o professor os oriente a recorrer ao projeto de pesquisa.

A pesquisa escolar, então, deve ser desenvolvida por todos os alunos, individualmente ou em pequenos grupos, de dois ou três, com produção de material escrito, como texto, painel, cartaz, etc., explorando a elaboração de gráficos, desenhos e, também, a interpretação de paisagens e imagens diversas. Se possível, a pesquisa deve ser apresentada oralmente, em sala de aula, ou através de outra forma de socialização, como em qualquer outra atividade escolar.

Quanto à avaliação da aprendizagem, dentro da metodologia do ensino pela pesquisa, ela deve acontecer em torno da própria produção da pesquisa pelos alunos, e não consistir em uma prova escrita sobre o assunto/conteúdo geográfico desenvolvido na pesquisa. Como exemplo, se a pesquisa for socializada oralmente, essa apresentação pode ser uma forma de avaliação, deixando previamente bem claros os critérios que serão avaliados.

Para encerrar esse texto, como contribuição, seguem alguns exemplos de assuntos/conteúdos que poderão ser tema de pesquisa escolar em Geografia:

a) Conceitos básicos da Geografia - pesquisa sobre a paisagem do bairro da escola. Problema: Que aspectos da globalização estão fortemente marcados na paisagem do bairro da escola? 
b) Conceitos básicos da Geografia - pesquisa sobre "o meu lugar", ou seja, os alunos irão pesquisar sobre algum lugar da cidade ou do município que consideram como sendo "seu lugar". Problema: Que lugar da cidade é o meu lugar? Ou por que ele é o meu lugar?

c) Setor terciário da economia municipal: pesquisa sobre algum aspecto do comércio da cidade, tendo como metodologia a aplicação de um questionário aos comerciantes. Problema: De onde vêm os principais produtos comercializados em nossa cidade?

d) Geografia Física do município - pesquisa sobre as formas do relevo do município. Problema: Como podemos representar o relevo do nosso município?

e) População do Estado - pesquisa sobre a caracterização do contingente populacional do Estado em que vivem os alunos. Problema: Quem são as pessoas que vivem em nosso Estado? Pode-se pesquisar no site do Instituto Brasileiro de Geografia e Estatística (IBGE), explorando as tabelas sobre população. 


\title{
REFERÊNCIAS
}

\begin{abstract}
ANTONIO, J. C. Pesquisa escolar na internet: Ctrl+C \& $\mathrm{Ctrl}+\mathrm{V}$ versus cópia manuscrita, professor digital, 31 jan. 2010. Disponível em: <http://professordigital.wordpress. com/2010/o1/31/pesquisa-escolar-na-internet-ctrlc-ctrlv-versuscopia-manuscrita/\&gt>. Acesso em: 19 jul. 2014.
\end{abstract}

BAGNO, M. Pesquisa na escola: o que é e como se faz. 7. ed. São Paulo: Edições Loyola, 2001.

BRASIL. Parâmetros Curriculares Nacionais (PCN): História e Geografia. 2. ed. Brasília, DF: Ministério da Educação: Secretaria de Educação Fundamental, 2000.

CALLAI, H. C.; CALLAI, J. L. Grupo, espaço e tempo nas séries iniciais. In: CASTROGIOVANNI, A. C. et al. (org.). Geografia em sala de aula: práticas e reflexões. Porto Alegre: AGB - Seção Porto Alegre, 1998. p. 61-70.

COSGROVE, D. A Geografia está em toda parte: cultura e simbolismo nas paisagens humanas. In: CORREA, R. L., ROSENDAHL, Z. (org.). Paisagem, tempo e cultura. 2. ed. Rio de Janeiro: EdUERJ, 2004. p. 92-123.

DEMO, P. Pesquisa: princípio científico e educativo. São Paulo: Cortez, 1996.

Educar pela pesquisa. 3. ed. Campinas: Autores Associados, 1998.

INÁCIO FILHO, G.; NUNES, S. do C. A pesquisa no ensino fundamental. Ensino em Re-vista, v. 7, n. 1, p. 95-112, jul. 98-jun. 99. Disponível em: <http://www.seer.ufu.br/index.php/ emrevista/article/view/7851>. Acesso em: 16 jul. 2014.

FREIRE, P. Pedagogia da autonomia: saberes necessários à prática educativa. São Paulo: Paz e Terra, 1996. 
MARTINS, J. S. Projetos de pesquisa: estratégias de ensino e aprendizagem em sala de aula. Campinas, SP: Armazém do Ipêe, 2005 .

MINAYO, M. C. de S. O desafio do conhecimento: pesquisa qualitativa em saúde. 2. ed. São Paulo: Hucitec: Abrasco, 1993. PONTUSCHKA, N. N.; PAGANELLI, T. L.; CACETE, N. H. Para ensinar e aprender Geografia. São Paulo: Cortez, 2007. 


\section{A VIOLÊNCIA NO \\ ESPAÇO ESCOLAR: \\ da segurança \\ do cotidiano ao cotidiano da \\ insegurança}

\section{Maria Cristina Rangel}

\section{INTRODUÇÃO}

Este trabalho tem por objetivo divagar, especular e refletir sobre a violência na escola. Trata-se de assunções de uma professora e mãe com um filho de 14 anos na escola, mais do que uma revisão de literatura ou um trabalho de pesquisa. Recorro à experiência profissional e à sensibilidade de quem observa e participa da vida escolar para juntos pensarmos sobre a violência na escola e a escola que queremos. Encaminhemo-nos às reflexões.

Nossas ações, muitas vezes, são guiadas pela repetição e constância dos fenômenos, principalmente daqueles ligados à natureza. Contamos de forma convicta que se não chover, haverá sol, que teremos um dia seguido de uma noite, que tudo que sobe desce, ou que a água quente em contato com a fria, ambas ficam mornas, e assim por diante. Em função das fortes evidências da imutabilidade dos fenômenos da natureza, programamos o cérebro e organizamos a vida baseados em determinadas certezas. Pela observação da repetição constante esperamos que haja, em qualquer lugar da Terra, uma reprodução daquilo que tem sido assim desde que os humanos são capazes de registrar. Nada garante que será eternamente assim, muito menos quando se faz uma transposição desta forma de pensar e agir para o cotidiano da vida social.

No cotidiano, naquilo que se sucede todos os dias, há uma tentativa de organizarmos a vida a partir da repetição. Todos os dias fazemos quase sempre tudo igual, contando que tudo funcionará de acordo com o previsto. Mesmo sabendo que somos mortais, suscetíveis de morrer a qualquer momento, sempre esperamos que nossos familiares retornem sãos e salvos para casa, ou que os de casa estejam bem ao voltarmos. Assim criamos a ilusão da estabilidade e nos protegemos do que é incerto. Não somos preparados para o que é avassalador e imprevisível. 
Neste sentido, enviamos nossos filhos para a escola com a certeza de que lá eles estarão bem, serão bem tratados, não sofrerão agressões, nem físicas e nem psicológicas. Quando chega o horário do retorno da escola, esperamos encontrá-los intactos. Criamos mentalmente a escola como o espaço da segurança, até mesmo sagrado, onde professores, funcionários e alunos se unem para ensinar e aprender, não só os conteúdos específicos de cada disciplina, mas também sobre ética, moral, solidariedade, compaixão, enfim, como ser e agir no mundo de forma que o mesmo seja bom para todos e não somente para uma parcela ínfima de privilegiados.

Hoje o que temos assistido é a profanação deste espaço. O espaço escolar, na verdade, nunca foi de todo sagrado. Agressões entre os alunos, dos professores em relação aos alunos, entre pais e professores, dos alunos com os funcionários e vice-versa, não são incomuns na história da educação. Entretanto, as formas de violência na escola têm se transformado. Conforme consta nas referências desse trabalho, algumas manchetes de jornais sobre os últimos acontecimentos nos dão ideia do que está acontecendo: "Aluna é agredida por cinco colegas dentro da sala de aula" (TV UOL, 2014a); "Aluno grava professor agredindo colega na sala de aula" (TV UOL, 2014b); "Professora é agredida por aluno dentro da sala de aula, em SP" (TV UOL, 2013a); "Professor dá tapa no rosto de aluna dentro da sala de aula (TV UOL, 2013b)"; "Professor agride aluno dentro de sala de aula" (TV UOL, 2013c); "Mãe agride professora dentro da sala de aula, na Bahia" (TV UOL, 2010); "Caso de aluno morto na Unicamp tem cinco responsáveis, diz polícia" (UOL EDUCAÇÃO, 2013); "Mãe de aluna mata professora em frente à classe, na França" (BBC BRASIL, 2014); "Massacre em Realengo. Tragédia em escola no Rio de Janeiro" (VEJA, 2011); "8 massacres em escolas que chocaram o mundo" (COHEN, 2012).

Agressões físicas com uso de armas, homicídios, massacres, estupros, tapas, golpes de artes marciais são expressões da violência que está acontecendo no espaço escolar e não somente no Brasil. A música "Tudo que eu sempre sonhei", interpretada pelo grupo Pullovers, traz uma reflexão sobre a violência nas escolas norte-americanas:

Já que se eu fosse americano

Pegaria uma pistola

E a cabeça ia perder a razão:

Mataria quinze na escola

Estouraria a caixola

E apareceria na televisão (VENÂNCIO, 2014, s/p). 
As agressões com tal nível de violência podem ainda ser raras - mesmo que cada dia mais frequentes -, mas já tiram a sensação de que na escola há segurança, e mais, dão a certeza de que para os violentos não há limites, nem quanto às formas, nem aos espaços onde ocorrem. Não temos mais a certeza de que nossos filhos chegarão inteiros em casa, quiçá vivos. Ou de que não matarão seus colegas.

\section{ViolêNCIA NaS ESCOlas. Por QUê?}

A pergunta é: por que isto está acontecendo?

A violência quando alcança a escola já está disseminada em outros espaços.

Vejamos:

Em 2012, 112.709 pessoas morreram em situações de violência no país, segundo o Mapa da Violência 2014, divulgado hoje. O número equivale a 58,1 habitantes a cada grupo de 100 mil, e é o maior da série histórica do estudo, divulgado a cada dois anos. Desse total, 56.337 foram vítimas de homicídio, 46.051, de acidentes de transporte (que incluem aviões e barcos, além dos que ocorrem nas vias terrestres), e 10.321, de suicídios (MARTINS, 2014, p.1).

Este aumento e disseminação da violência são particulares do Brasil? Há fortes indícios de que não. Trata-se da transmutação da competição, aquela com regras claras, dentro de um código de ética, para a competitividade, em que se quer ganhar a qualquer custo, inclusive por meio da eliminação dos oponentes, daqueles que se colocam como obstáculos às intencionalidades de cada um.

Neste sentido, Santos (2000, p. 23) assim se posiciona:

Agora, a competitividade toma o lugar da competição. A concorrência atual não é mais a velha concorrência, sobretudo porque chega eliminando toda forma de compaixão. A competitividade tem a guerra como norma. Há, a todo custo, que vencer o outro, esmagando-o, para tomar seu lugar.

A competitividade, aliada ao fato de $50 \%$ da população mundial viver nas áreas urbanas; destes um terço estar em favelas (ONUBR, 2013); 
e de que as relações sociais são cada vez mais intermediadas por objetos técnicos, como o telefone celular, cria uma situação explosiva.

Viver em espaços urbanos, em aglomerados urbanos, implica em compartilhar deste espaço, em seguir regras de convivência e ter limitações. Descobrimos, à contra gosto, que o mundo não é só nosso. Quando se está em uma sociedade em que prevalece a competitividade em detrimento à solidariedade e à compaixão, o individualismo e não a abnegação, a área urbana se transforma em um campo de batalha de todos contra todos, de cada um lutando para ter um lugar onde morar, onde circular e estacionar o carro ou mesmo por um assento no ônibus, metrô... Cada um na sua, com sua mercadoria (é preciso que cada um tenha a sua para aumentar a quantidade de consumidores), e todos pelo dinheiro.

$\mathrm{Na}$ sociedade do consumo, em que as mercadorias valem mais do que as pessoas, há o dispêndio de energia para obtê-las mais e mais, num círculo vicioso e frustrante, porque permanentemente se fabricam novas mercadorias e necessidades, não exatamente nesta ordem. Não se fabricam objetos somente para atender às necessidades, criam-se necessidades do novo, tornando imediatamente obsoleto o que acabou de ser lançado como novidade. E assim, a busca é por mais dinheiro para comprar mais mercadorias:

O resultado objetivo é a necessidade, real ou imaginada, de buscar mais dinheiro, e, como este, em seu estado puro, é indispensável à existência das pessoas, das empresas e das nações, as formas pelas quais ele é obtido, sejam quais forem, já se encontram antecipadamente justificadas (SANTOS, 2000, p. 28).

E vamos acumulando tensões e frustrações, nosso nível de tolerância vai baixando, até que um dia a fúria supera a racionalidade e explodimos de raiva no trânsito, com a atendente de telemarketing, com porteiros, com professores, ou seja, principalmente com aqueles que na hierarquia social, supomos estar em posição de subalternidade.

Este estado de tensão social, de quase esgarçamento das relações sociais, é potencializado quando aumenta a densidade demográfica, e nas cidades, os bairros de maior quantidade de pessoas por metro quadrado são favelas, local de pessoas destituídas das condições mínimas de sobrevivência com seu próprio trabalho; do exercício pleno da cidadania; dos direitos humanos. Nesses locais os índices de violência são maiores. São os territórios dos excluídos da sociedade de consumo, dos que só podem consumir os piores lugares para se morar nas cidades: terrenos alagados, 
mangues, morros de alta declividade, periferias das grandes cidades, ou seja, onde o terreno é mais barato ou onde quase ninguém deseja morar. Nesses locais impera a ilegalidade jurídica do terreno ocupado, da casa mal construída, do terreno que traz riscos à saúde.

Por medo dos outros (e nós somos os outros para os outros) criamos barreiras de isolamentos. Subimos a altura do muro, colocamos cercas elétricas, câmeras de vídeo, plantas espinhentas, compramos cachorros bravos e os colocamos no quintal, instalamos alarmes... construímos condomínios fechados, os feudos pós-modernos. E intermediamos nossas relações societárias por objetos técnicos, comunicamo-nos com o mundo via telefone, internet, mas não conhecemos o vizinho ao lado. A falta de convívio comunitário nos imuniza com relação ao que acontece aos outros e nos anestesia emocionalmente; a falta de alguém que se oponha ao que pensamos nos dá a ilusão de estarmos sempre certos, não suportamos o embate de ideias e adotamos o porquê sim sem discussão.

Entra em campo outro complicante. Queremos tudo agora, neste instante, já. Estamos muito apressados nas relações sociais que estabelecemos. Prevalece a efemeridade, a sucessão de instantes que nos deixam sem oriente. Já não conseguimos construir um projeto de sociedade, como fizemos no passado, pois ficamos no consumo do agora, com dificuldades de pensar no futuro. Neste sentido, os políticos estão mais preocupados com a política eleitoreira do que com uma proposta política para a sociedade; quando muito se preocupam em se manter no poder, atendendo reivindicações de grupos particulares: agropecuaristas, empreiteiros, doleiros, industriários, banqueiros, mulheres, homossexuais, semterra, sem-teto e gente de todos os matizes. Mesmo que as discussões nas redes sociais sejam polarizadas ainda nas ideias de partidos de direita e de esquerda, na prática dos políticos o que assistimos são coligações inimagináveis até pouco tempo, uma verdadeira promiscuidade partidária. E a ideologia predominante é a de que não há ideologia.

\section{A BOMBA DO INDIVIDUALISMO, A COMPETITIVIDADE E O CONSUMO ALCANÇAM A ESCOLA}

Quais as relações de tudo isto com a violência na escola? Perguntando de outra maneira: como isto se apresenta no espaço escolar? Afinal, a escola não é um espaço à parte da sociedade que a originou e mantém.

Quando o acúmulo de bens ao longo da vida dá mais status do que o conhecimento que se adquire, a escola, como o locus da produção do 
conhecimento, perde valor. Seus muros, que um dia foram limites para a violência extramuros, hoje são adentrados sem cerimônias por traficantes de drogas que vão ali para vender, acertar contas ou eliminar os membros das facções que concorrem pelo domínio territorial do bairro onde está localizada a escola. Invadem ou miram suas armas para o interior das escolas, atingindo a todos indiscriminadamente. E têm aqueles que escolhem as escolas para poder matar o maior número possível de pessoas.

Além dessa invasão, outra acontece: a dos pais. A intolerância dos pais, já cansados da competitividade diária, da busca incessante por mais dinheiro, atinge a escola na forma de agressão. Pais batem em alunos que bateram em seus filhos, desacatam os professores porque seus filhos tiraram nota baixa, repetiram de ano, foram advertidos...

Há a violência praticada entre alunos e os representantes institucionais: professores e funcionários. Neste caso a violência é recíproca, mas expressa de formas diferentes, cada um usando as armas, as estratégias e os mecanismos de poder que possui. De um lado, os jovens afoitos, sem muitas artimanhas; do outro, dissimulação, cinismo, arbitrariedade, autoritarismo e preconceitos de toda ordem.

A escola, tanto no aspecto físico quanto no pedagógico, não está em sincronia com a dinâmica da sociedade. A sociedade mudou, mas os prédios e as práticas pedagógicas continuam as mesmas do passado, quando as escolas tinham como intenção disciplinar os corpos e as mentes para o trabalho nas fábricas, escritórios... preparar os alunos para o trabalho e para o exercício de determinada cidadania conveniente aos empoderados do momento. Essa escola não serve mais e os alunos são os primeiros a sofrerem e a reagirem vandalizando a escola - estourando os vasos sanitários, riscando carteiras e paredes, ateando fogo, acendendo incensos de cheiros insuportáveis - ou agredindo fisicamente os que estão neste ambiente, inclusive os próprios colegas.

Quais são os motivos para que os alunos se agridam? Os preconceitos construídos extramuros também extravasam na escola. Por que o outro é gordo ou magro, homossexual ou heterossexual, preto ou branco, mulher ou homem, rico ou pobre, feio ou bonito, cabelo liso ou crespo, mora aqui ou ali, ouve axé ou rock, fala baixo ou alto, veste esta ou aquela roupa, anda "assim ou assado"... os motivos são fabricados no momento, sejam eles traços fenótipos ou marcações sociais.

Professores mal formados, mal remunerados, sobrecarregados de trabalho, avaliados socialmente (negativamente) pelo que NÃO podem ter - carrões, roupas de marcas famosas, estética dos atores globais - são postos 
diante de alunos que se recusam a aprender, que querem subverter a ordem da escola, pois não suportam mais permanecer várias horas sentados tendo aulas, quando em casa têm toda parafernália tecnológica a sua espera. A ausência de perspectivas de uma sociedade melhor, de um projeto de sociedade, influencia na prática dos professores ao criarem aulas que não excitam, não motivam, presas à reprodução de conteúdos em detrimento à produção do conhecimento e reflexões sobre a sociedade em que vivemos.

\section{Conclusão}

Imaginar uma escola como local onde impera a paz, a confiança, o respeito mútuo, a amizade e o companheirismo, é ilusão. As pequenas transgressões são comuns ao ambiente escolar e geralmente são resolvidas intramuros, às vezes, com o envolvimento dos pais. A agressividade, quando identificada, conduzida pela escola, canalizada para os esportes, as artes, pode até ter resultados positivos. Não é dessa agressividade que estamos falando. Referimo-nos à violência que resulta em agressões físicas, mortes, destruição do patrimônio escolar com o intuito de violentar os representantes institucionais ou mesmo a sociedade que cria e mantém a escola. É uma nova forma de violência, aquela carregada de ódio, de vontade de ferir, destruir o outro com fúria, humilhar; uma agressão desproporcional a qualquer ato que se tenha praticado.

A escola não é o local da violência, mas já temos a sensação de que intramuros tudo é possível. É necessário a construção de uma outra escola, mais adequada à ciência, informação e tecnologias que dispomos hoje. Isto, entretanto, não será suficiente se, concomitantemente, não tivermos outras construções, como a de uma sociedade mais justa, ética, solidária, honesta, menos competitiva, mais política e menos eleitoreira, menos fútil no consumo, mais produtora de arte, cultura e, principalmente, de gente feliz simplesmente por se reunir, poder comungar dos anseios, lutas, fracassos e vitórias, próprios da existência humana.

Atribuir culpa pelos massacres em escolas somente aos indivíduos que os praticaram, como se fossem atos isolados de um louco, é tentar "tapar o sol com a peneira"; de forma mal intencionada, há a tentativa de descontextualizar histórica e geograficamente o sujeito, para não fazer crítica à sociedade produtora de mercadorias e consumidores frustrados. 


\section{REFERÊNCIAS}

$\mathrm{BBC}$ Brasil. Mãe de aluna mata professora em frente à classe na França. [São Paulo], 2014. Disponível em: <http://noticias.uol.com.br/ultimas-noticias/bbc/2014/o7/04/mae-de-aluna-mata-professora-em-frente-a-classe-na-franca.htm>. Acesso em: 14 jul. 2014.

COHEN, O. 8 massacres em escolas que chocaram o mundo. São Paulo, 2012. Disponível em: <http://super.abril.com. br/blogs/superlistas/8-massacres-em-escolas-que-chocaram-o -mundo/>. Acesso em: 11 jul. 2014.

MARTINS, H. Mapa mostra aumento e disseminação da violência no Brasil. EBC. Brasília, DF, 2014. Disponível em: $<$ http://agenciabrasil.ebc.com.br/geral/noticia/2014-07/p-2brasil-viveu-aumento-e-disseminacao-da-violencia-segundo-mapada-violencia>. Acesso em: 9 jul. 2014.

ORGANIZAÇÃO DAS NAÇÕES UNIDAS (Brasil) (UNUBR). ONU: mais de $70 \%$ da população mundial viverá em cidades até 2050. Brasília, DF, 2013. Disponível em: <http:// www.onu.org.br/onu-mais-de-7o-da-populacao-mundial-vivera -em-cidades-ate-2050/>. Acesso em: 10 jul. 2014.

SANTOS, M. Por uma outra globalização: do pensamento único à consciência universal. 3. ed. Rio de Janeiro: Record, 2000.

TV UOL. Aluna é agredida por cinco colegas dentro da sala de aula. São Paulo, 2014a. Disponível em: <http://tvuol.uol. com.br/video/aluna-e-agredida-por-cinco-colegas-dentro-dasala-de-aula-04024C9C366ACC815326/>. Acesso em: 14 jul. 2014 . 
TV UOL. Aluno grava professor agredindo colega na sala de aula. São Paulo, 2014b. Disponível em: <http://tvuol.uol.com. br/video/aluno-grava-professor-agredindo-colega-na-sala-de-aula-04020E993968DoA14326>. Acesso em: 14 jul. 2014.

. Mãe agride professora dentro da sala de aula na Bahia. São Paulo, 2010. Disponível em: <http://tvuol.uol. com.br/video/mae-agride-professora-dentro-da-sala-de-aula-na -bahia-04028C1A346CDo813326>. Acesso em: 14 jul 2014.

. Professora é agredida por aluno dentro da sala de aula em SP. São Paulo, 2013a. Disponível em: <http://tvuol.uol. com.br/video/professora-e-agredida-por-aluno-dentro-da-sala-de -aula-em-sp-04020E1C396AD8994326>. Acesso em: 14 jul. 2014.

. Professor dá tapa no rosto de aluna dentro da sala de aula. São Paulo, 2013b. Disponível em: $<$ http://tvuol.uol. com.br/video/professor-da-tapa-no-rosto-de-aluna-dentro-da-sala-de-aula-04024D99386ED8A14326>. Acesso em: 29 ago. 2014.

. Professor agride aluno dentro de sala de aula. São Paulo, 2013c. Disponível em: <http://tvuol.uol.com.br/video/ professor-agride-aluno-dentro-de-sala-de-aula-o402०E9B3568DoAr4326>. Acesso em: 14 jul. 2014.

UOL. Caso de aluno morto na Unicamp tem cinco responsáveis, diz polícia. São Paulo, 2013d. Disponível em: <http://educacao.uol. com.br/noticias/2013/10/o3/caso-de-aluno-morto-na-unicamp-temcinco-responsaveis-diz-policia.htm>. Acesso em: 4 jul. 2014.

VEJA. Massacre no Realengo: tragédia em escola no Rio de Janeiro. São Paulo, 2011. Disponível em: <http://veja.abril. com.br/multimidia/galeria-fotos/tragedia-em-escola-no-rio-dejaneiro>. Acesso em: 9 jul. 2014.

VENÂNCIO, Luiz. Tudo que eu sempre sonhei. Interprete: Pullovers. UOL Educação, São Paulo, [2014]. Disponível em: <http:// letras.mus.br/pullovers/1491437/>. Acesso em: 14 jul. 2014. 


\section{O ENSINO DE GEOGRAFIA NUM MUNDO DOMINADO \\ PELA MÍDIA, PERMEADO \\ PELA IMAGEM E \\ SUBMETIDO AO \\ ESPETÁCULO}

\section{Gilsélia Lemos Moreira}

"Com tais ideias pretende-se explicar a realidade, sem se perceber que são elas que precisam ser explicadas pela realidade".

Marilena Chauí

\section{INTRODUÇÃO}

Esse artigo discute a intensa imbricação entre ensino de Geografia, mídia, imagem e espetáculo. Tomando esta articulação como um aspecto central do contexto contemporâneo, elaboramos algumas reflexões acerca de padrões e modelos fornecidos pela cultura da mídia na atualidade, focando a importância da imagem cuidadosamente lapidada como estetização da realidade e o espetáculo como abstração do mundo.

Nosso objetivo é dialogar com o professor de Geografia, tendo como horizonte a possibilidade dessa ciência, enquanto disciplina produzir um conhecimento crítico do mundo que é permeado pela imagem, dominado pela mídia e submetido ao espetáculo.

Para tornar o texto mais claro e objetivo em relação ao tema proposto nesse artigo, tomaremos como ponto de partida a análise de padrões e modelos fornecidos pela cultura dominada por imagens, onde a mídia tem um papel fundamental na produção de narrativas que criam um universo de ilusão. 
Cada vez mais, a realidade se confunde com as representações, uma excessiva exposição imagética na qual reina um simulacro1. De acordo com Pereira (2013, p. 12), "a sociedade pós-moderna foi invadida pela ascensão da mídia, que privilegia a superfície". Baudrillard defende a teoria de que vivemos em uma era cujos símbolos têm mais peso e mais força do que a própria realidade. Ele diz:

Hoje a abstração já não é a do mapa, do duplo, do espelho ou do conceito. A simulação já não é a simulação de um território, de um ser referencial, de uma substância. É a geração pelos modelos de um real sem origem nem realidade: hiper-real. O território já não precede o mapa, nem lhe sobrevive. É agora o mapa que precede o território - precessão dos simulacros - é ele que engendra o território cujos fragmentos apodrecem lentamente sobre a extensão do mapa. É o real, e não o mapa. Cujos vestígios subsistem aqui e ali, nos desertos que já não são os do império, mas o nosso. $\mathrm{O}$ deserto do próprio real (BAUDRILLARD, 1981, p. 5).

A partir deste ponto de vista, o real não é o real, pelo menos da forma como concebemos o que é real, mas a sua simulação, ou seja, disfarçado de real e assim é comparado com o ideal, trata-se de uma realidade à parte, desvinculada do original, desfigurada, uma cópia, como diz Pereira (2013, p.12), ao citar Baudrillard (2008), "produzindo uma realidade à parte ou o "hiper-real", [...] coleção de cópias [...]".

A análise, para além da busca de modelos de interpretação, nos direciona ao entendimento da realidade. Mas, devemos estar atentos às palavras de FEUERBACH citado por DEBORD, (2003, p. 13), "Nosso tempo, sem dúvida [...] prefere a imagem à coisa, a cópia ao original, a representação à realidade, a aparência ao ser [...]”.

Considerando que a mídia fomenta realidades ilusórias, usamos a noção de simulacro não como sinônimo de falso, mas no sentido de uma coisa estar no lugar de outra, como uma encenação.

2 Sobre esse assunto, Maffesoli (1999) defende que o mundo e a sociedade pós-moderna estão centrados na aparência e na banalidade das coisas e tal efemeridade dá razão e sentido à vida cotidiana. $\mathrm{O}$ autor postula que o corpo, as roupas são meios de comunicação, e que a vida urbana é a vida das aparências. Ele considera que em nosso tempo está instaurado um hedonismo coletivo, o ideal do carpe diem em que tudo deve ser vivido e aproveitado imediatamente. Por ter um grande impacto imagético, a mídia trabalha com a aparência, considerada a primeira camada significativa. 
Partindo das considerações de Debord (2003), que ressaltam que as simulações são mais atraentes ao espectador do que o próprio objeto reproduzido pode-se inferir que esses simulacros são, antes de tudo, "construções do mundo" que se transforma em cenário para o "espetáculo". Neste contexto, como disseram Alves, Adilson, Alves e Adriana (2004, p. 143):

O espetáculo mundial materializa-se como extensão de uma razão instrumental. Num processo antropofágico a fluidez do mundo é tragada e, quando reelaborada, é devolvida aos fragmentos. Entretanto, estes pedaços de realidade encontram na sua forma 'espetacular' uma aura de totalidade, não apenas explicativa, mas portadora da capacidade de se tornar catalizadora de uma realidade já devidamente mitificada ou glamourizada, transformando-se em motor da própria realidade, 'fazendo o mundo girar' (grifos do autor).

Para tornar as ideias aqui apresentadas mais fluídas e articuladas, tomaremos como ponto de partida o conceito de mídia a partir de Setton, (2011, p. 14), que diz:

O conceito de mídia é abrangente e se refere aos meios de comunicação massivos dedicados, em geral, ao entretenimento, lazer e informação - rádio, televisão, jornal, revista, livro, fotografia e cinema. Além disso, engloba as mercadorias culturais com a divulgação de produtos e imagens e os meios de comunicação, ou seja, jogos eletrônicos, celulares, DVDs, CDs, TV a cabo ou via satélites e, por último, os sistemas que agrupam a informática, a TV e as telecomunicações - computadores e redes de comunicação.

Do acordo com Pereira (2013), na contemporaneidade, a mídia ocupa um dos lugares centrais na produção das discursividades, formando, parcialmente, a opinião pública, atuando não só como meio de produção e circulação de textos, mas, também, como fonte de discursos que fundamentam e orientam nossas atuais relações sociais. Segundo Thompson (2002), o poder simbólico utiliza os recursos dos meios de informação e comunicação para influenciar, induzir, sugerir ações que podem intervir no curso dos acontecimentos e produzir novos eventos.

Na produção de formas simbólicas, os indivíduos se servem destas e de outras fontes para realizar ações que possam intervir no curso dos acontecimentos com consequências as mais 
diversas. As ações simbólicas podem provocar reações, liderar respostas de determinado teor, sugerir caminhos e decisões, induzir a crer e a descrer, apoiar os negócios do Estado ou sublevar as massas em revolta coletiva. Usarei o termo "poder simbólico" para me referir a esta capacidade de intervir no curso dos acontecimentos, de influenciar as ações dos outros e produzir eventos por meio da produção e da transmissão de formas simbólicas (THOMPSON, 2002, p. 24, grifo nosso).

A mídia tem se constituído em importante agente de socialização, sensibilização e mobilização dos cidadãos, os quais têm um papel decisivo nas transformações territoriais, e que se manifesta seja em ações ou omissões. Ao influenciar a opinião dos cidadãos e, portanto, os gradientes de envolvimento sobre quaisquer temáticas ou problemas, a mídia acaba por se tornar importante referência a nortear as ações dos próprios governos, que se orientam por parâmetros de popularidade, imprescindíveis para sua legitimação e manutenção no poder.

Simultaneamente, a mídia influencia a percepção que os sujeitos políticos têm dos problemas e, não raro, interfere na definição de agendas políticas (CARVALHO, 2002). Seguindo esta mesma linha de raciocínio, Helena Cristina Máximo, em sua tese de doutorado, sob o mote "A presença da mídia na ação política: evidências de uma influência discursiva", elabora o seguinte pensamento:

A mídia não muda somente o comportamento estratégico dos agentes políticos em direção ao público, mas concretiza uma influência estruturante sobre os princípios das escolhas que caracterizam o processo de decisão, dispondo, para isso, de um capital simbólico privilegiado. Indo ao encontro do reconhecimento social extremamente arraigado sobre os produtos da mídia, as palavras dos parlamentares indicam suas formas de reconhecer a validade do produto característico do campo da mídia, a informação. O discurso abre espaço para compreender melhor o jogo que se dá, na esfera pública, entre os detentores do poder de comunicação, ou seja, os que dominam as esferas de visibilidade, e os detentores de poder político, ocupantes de cargos no parlamento e no governo (MAXIMO, 2008, p. 5).

A mídia institui um universo no qual muitas questões são socialmente elaboradas a partir de seus próprios interesses. O tempo todo, a mídia está expressando determinadas conveniências, proclamando apoio a determinados governos, criticando outros, enfim, manipulando as ideias das pessoas. Segue um exemplo para ilustrar esta reflexão. 
O caso Fernando Collor de Melo consiste em uma oportunidade para estudar as formas de (des)construção de imagem pública e o papel da mídia nesse processo. Como Fernando Collor de Melo venceu a corrida presidencial, quais foram as estratégias de marketing político utilizadas, de que forma o escândalo abalou a sua imagem, quais os interesses da mídia em Collor de Melo e qual foi a participação da mídia na ascensão e na queda da imagem do primeiro candidato eleito por voto direto após o regime militar à Presidência da República (SILVA, 2012, p. 89).

O caso Fernando Collor de Melo é um exemplo do poder da mídia no processo de construção ou desconstrução da imagem. Isso se dá, por meio de informações manipuladas e sentido crítico ambíguo. É a partir das mensagens veiculadas nos meios de comunicação e, principalmente, da televisão que esta estratégia se realiza.

Somos bombardeados diariamente por informações insignificantes que nada acrescentam, tampouco permitem a reflexão. Somos distraídos por programas de TV que nos apresentam um mundo belo e perfeito, distante do mundo real, repleto de problemas de toda ordem. Os esplêndidos comerciais que vendem marcas e produtos dos quais não precisamos e as mensagens de cunho emocional são algumas das táticas usadas pela mídia massificadora e alienante para manter a maior parte dos sujeitos na ignorância e na mediocridade.

Essa é também uma forma eficaz de evitar a construção de uma consciência crítica por parte dos sujeitos e, assim, promover mudanças sociais e culturais. Para Leão e Carvalho (2008, p. 27),

pela força com que se impõe o discurso contido na mídia, este acaba construindo uma única visão do mundo, o que contribui para o fortalecimento do pensamento único, mantenedor do status quo vigente.

Nessas reflexões, a destruição do "sentido crítico dos indivíduos" está prefigurada como possibilidade inscrita. Enquanto a mídia continuar conduzindo a sociedade por meio da imagem e do espetáculo, a atrofia da imaginação e a sangria da exploração dos indivíduos são possibilidades imanentes.

Isto nos coloca diante de uma série de desafios, decorrentes das transformações aceleradas, que nos fazem perder a noção de continuidade e a compreensão espaço-temporal. Prevalece o fugaz, o midiático, o imagético. Compreendemos, dessa forma, que: 
A incorporação das mídias no ensino é uma realidade no mundo contemporâneo a ser enfrentado e trabalhado constantemente para tentar ultrapassar os objetivos imediatistas do mercado. Para tanto, necessita discutir e debater as modificações em um mundo que está mudando rapidamente; compreender através deste instrumento a importância da Geografia como ciência comprometida em analisar e refletir sobre o espaço construído e reproduzido pelo homem e, desta forma, possibilitar um olhar mais aguçado dos alunos perante as informações que são disseminadas ao público em geral e, assim, não serem tão influenciados pelas grandes corporações midiáticas que disseminam diversos símbolos (CARVALHO, 2013, p. 11).

Podemos asseverar, portanto, que:

A Geografia, entendida como uma ciência social, que estuda o espaço construído pelo homem a partir das relações que estes mantêm entre si e com a natureza, quer dizer, as questões da sociedade, com uma "visão espacial", é por excelência uma disciplina formativa, capaz de instrumentalizar o aluno para que exerça de fato a sua cidadania (CALLAI, 2001, p. 134, grifo nosso).

De acordo com Oliva (1999, p. 35), ao citar John Berger, um importante escritor anglo-saxônico, não geógrafo, "a Geografia é a mais poderosa e reveladora perspectiva, crítica do mundo contemporâneo". Straforini (2004, p. 47) ao citar Oliveira (1998), afirma que: "a Geografia vem sendo chamada cada vez mais para explicar o mundo". Nessa nova perspectiva a Geografia coloca no centro das preocupações as relações entre a sociedade, o trabalho e a natureza na produção do espaço geográfico. A Geografia

tem procurado pensar seu papel nessa sociedade em mudança, indicando novos conteúdos, reafirmando outros, reatualizando alguns outros (CAVALCANTI, 2002, p. 11).

Isso significa uma tentativa de compreender a realidade de forma mais crítica e mais aprofundada. Aliás, reside aqui um desafio: pensar o mundo em sua totalidade a partir de uma ciência parcelar. Nessa linha de raciocínio, entende-se que é preciso, portanto, formar uma consciência espacial para a prática da cidadania. O objetivo precípuo do ensino de Geografia deve ser o de criar um pensar geográfico que leve em consideração a realidade em seu movimento contraditório. Destarte, o papel da Geografia é ir além das atividades tradicionais, dos muros da escola, 
é transpor as barreiras invisíveis do cabresto midiático e assim superar a ideia de mundo real - o mundo do simulacro.

Nesse processo, o envolvimento dos sujeitos, em sua totalidade, é fundamental. A Geografia, na condição de ciência crítica, é ativa, possibilita a superação da ideia de que "nada sabemos ou somos sem o auxílio da mídia”. Pode nos capacitar a agir, interagir, refletir e, consequentemente, evitar o acúmulo de informações midiáticas. $\mathrm{O}$ verdadeiro desafio consiste na mudança radical do lugar e do significado da Geografia enquanto ciência.

O movimento aqui pretendido é a construção de uma "Geografia crítica radical". Trata-se de uma Geografia, capaz de revelar as contradições constitutivas do processo desigual da produção contemporânea do espaço, e que pode potencializar o "negativo" desse processo. Ana Fani A. Carlos nos ajuda a pensar nessa direção ao propor o caminho da metageografia,

\begin{abstract}
como uma nova inteligibilidade, através da crítica ao pensamento estabelecido, realizaria a crítica da produção teórica sobre o mundo visando entender, em profundidade, sua dinâmica contraditória por trás de "novas aparências" que fundam um mundo de imagens e das ideologias. O pensamento que vai à raiz das ações dominantes em nossa sociedade e as ilumina, pode propor caminhos para a superação das alienações vividas por uma sociedade submetida ao poder do Estado e das ideologias. Portanto, um projeto deve sair do seio da sociedade e realizar-se para além do Estado e esse é o nosso desafio (CARLOS, 2001, p. 1).
\end{abstract}

Esta orientação torna possível a elaboração de um projeto de uma sociedade mais justa, capaz de compreender e superar o paradoxo da servidão voluntária, num mundo dominado pela mídia, permeado pela imagem e submetido ao espetáculo.

\title{
Conclusão
}

Vivemos um momento em que os símbolos têm mais força do que a própria realidade, pois, as simulações se apresentam mais atraentes aos sujeitos do que o próprio objeto reproduzido. Nesse processo, a mídia exerce um importante papel de influenciar a percepção dos indivíduos que, cada vez mais, confundem a realidade com as representações. Somos bombardeados diariamente por uma excessiva exposição imagética na qual reina um simulacro, ou seja, uma encenação. 
Somos distraídos por programas de TV que nos apresentam um mundo ideal, belo e perfeito, distante do mundo real, repleto de contradições. A mídia é a condutora de todo esse processo: por meio da imagem e do espetáculo, ela atrofia a imaginação, elimina a possibilidade de reflexão, massifica as opiniões, constrói e desconstrói imagens de políticos e personalidades de acordo com os seus interesses.

Somos alimentados por informações insignificantes que nada acrescentam, tampouco permitem o exercício do livre pensar. Estamos cercados de padrões e modelos fornecidos pela cultura da mídia, cujo foco é a imagem cuidadosamente lapidada como estetização da realidade. Sendo assim, o espetáculo aparece como abstração do mundo real. A Geografia, nesse contexto, tem como desafio formar uma consciência espacial capaz de superar o poder de influência da mídia, da imagem e do espetáculo. 


\section{REFERÊNCIAS}

ALVES, A. F.; ALVES, RAMAZOTTI, A. M. Mídia, corpo e cidadania: reflexões sobre a construção do sujeito na sociedade midiática. Revista Faz Ciência, Francisco Beltrão, v. 6, n. 1, p 137-152, 2004. Disponível em <https://www.google.com.br/\#$\mathrm{q}=\mathrm{m} \% \mathrm{c} 3 \% 8 \mathrm{ddia} \% 2 \mathrm{c}+\mathrm{corpo}+\mathrm{e}+\mathrm{cidadania}+$ +reflex\%c3\%95es+sobre+a>. Acesso em: 15 maio 2007.

CARLOS, Ana Fani Alessandri. A "Geografia crítica" e a critica da Geografia. Revista Electrónica de Geografía y Ciencias Sociales, v. 11, n. 245, p. 1, ago. 2007. Disponível em http://www.ub.edu/geocrit/sn/sn-24503.htm Data de acesso: $15 / 05 / 2001$

CALLAI, H. C. A Geografia e a escola: muda a Geografia? Muda o ensino? Revista Terra Livre, São Paulo, n. 16, p. 133152, 1 sem. 2001. Disponível em <http://www.agb.org.br/publicacoes/index.php/terralivre/article/viewFile/353/335>. Acesso em: 15 maio 2007 .

CAVALCANTI, L. de S. Geografia e prática de ensino. Goiânia: Alternativa, 2002.

BAUDRILLARD, J. Simulacros e simulação. Lisboa: Relógio D’Água, 1981.

DEBORD, G. A sociedade do espetáculo. São Paulo: Contraponto, 2003 .

LEÃO, V. de P.; LEÃO, I. de C. Ensino de Geografia e mídia - linguagens e práticas pedagógicas. 2. ed. Belo Horizonte: Fino Traço, 2012.

MAFFESOLI, M. No fundo das aparências. 2. ed. Petrópolis: Vozes, 1999. 
MÁXIMO, H. C. A presença da mídia na ação política:

evidências de uma influência discursiva. 2008. 121 f. Dissertação (Mestrado em Ciência Política)- Universidade de Brasília, Brasília, DF, 2008.

OLIVA, J. T. Ensino de Geografia: um retardo desnecessário. In: CARLOS, A. F. A. (org.) A Geografia em sala de aula. São Paulo: Contexto, 1999.

PEREIRA. T. M. ${ }^{a}$ A. O espetáculo de imagens na ordem do discurso midiático: o corpo em cena nas capas da Revista Veja. [2013]. 203 f. Tese (Doutorado em Linguística)- Programa de Pós- Graduação em Linguística, Universidade Federal da Paraíba, João Pessoa, 2013.

SETTON, M. ${ }^{a}$ da G. Mídia e educação. São Paulo: Contexto, 2011.

SILVA, J. G. da. A mídia na construção e destruição da imagem: o caso Collor de Melo. Revista Senso Comum, Goiás, Samambaia, n. 2, p. 88-106, 2012.

THOMPSON, J. B. A mídia e a modernidade. Petrópolis:

Vozes, 2002. 


\section{SEÇÃO II}

\section{ENSINO DE GEOGRAFA: DIMENSÕES TÉ́RICAS PARA REFLEXX̃̄OE AUXILIO à PRÁTICA EM SALA DE AULA}

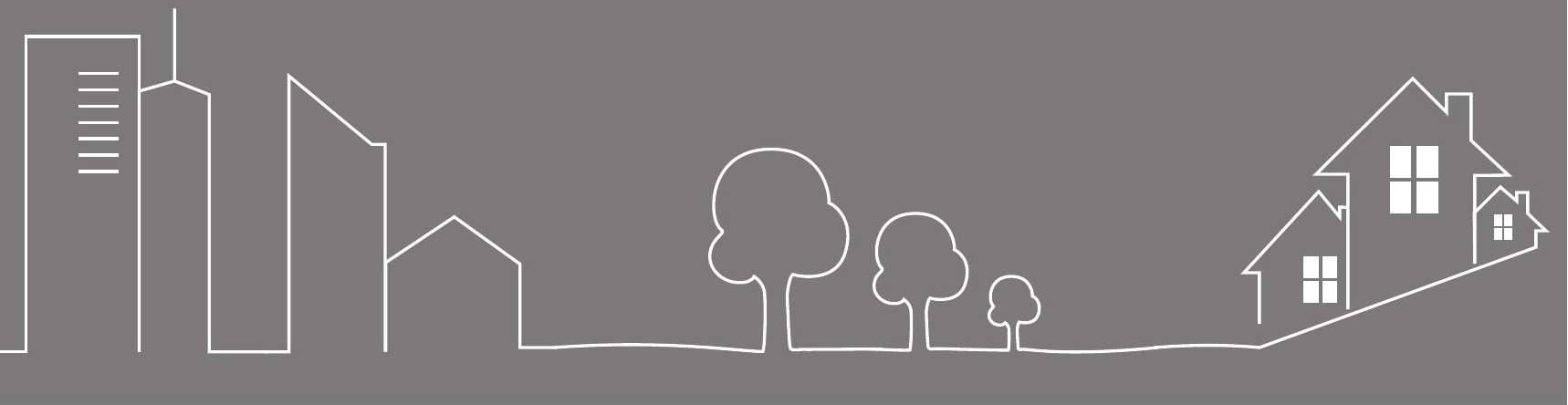




\section{RIO ALMADA: \\ agonia de uma alma hídrica}

\section{Lurdes Bertol Rocha}

O rio não precisa ser nosso; a água não precisa ser nossa. A água anônima conhece todos os meus segredos. E a mesma lembrança jorra de cada fonte.

Gaston Bachelard

Nunca dê nome a um rio: sempre é outro rio a passar.

Mário Quintana

\section{ANTES DA INTRODUÇÃO}

O texto que se segue é resultado de reflexões após reler a monografia produzida nos anos de 1995, cujo título é "Caracterização ambiental da bacia do rio Almada (sul da Bahia) - aspectos socioambientais" (ROCHA; AZEVEDO; CARMO, 1995). As informações sobre a bacia, seus aspectos naturais e socioculturais são resultado de pesquisa de campo (constantes na monografia acima citada), entrevistas com ribeirinhos, pesquisas feitas pela instituição federal Comissão Executiva para o Plano da Lavoura Cacaueira (CEPLAC) e pesquisas na internet (principalmente as fotos). O objetivo desse texto é oferecer aos professores do ensino básico uma reflexão sobre a importância de se conhecer o que está acontecendo com os rios de sua cidade, de seu município, discutir isso com os alunos, com a comunidade; levar os alunos a observarem o comportamento da comunidade no que tange ao uso das águas de seus rios, a forma como os tratam, etc. Sem entender, efetivamente, as causas e os efeitos dos problemas vividos pelos rios, não há como tomar consciência de sua importância e das ações a serem executadas para trazer de volta a vida dessa fonte tão importante para a manutenção do ecossistema de nosso planeta.

\section{INTRODUÇÃO}

A vida deve sua existência a uma harmoniosa combinação entre os elementos: terra, ar, água e fogo. São eles básicos para tudo o que existe 
no planeta Terra. Do reino vegetal ao humano, a terra é o suporte para seu desenvolvimento. Se a terra é o berço da vida, o ar é a sua fonte, pois é ele que carrega vida para nossos pulmões e é ele que transporta para fora o que já não serve mais. É através do primeiro sopro que vivemos, e do último, que partimos. O fogo, por suas propriedades, é capaz de transformar a matéria em novas substâncias, até mesmo reduzi-las a cinzas. De maneira geral, nenhuma impureza, quer seja mineral ou orgânica, pode resistir à sua ação. É por isso que os antigos alquimistas o utilizavam como agente de transmutação em suas tentativas de transformar metais. O fogo, ao se consumir, gera luz e é fonte de calor. A água, tema mestre deste trabalho, forma em torno de $70 \%$ de nosso corpo, entrando com $90 \%$ na composição de nosso sangue. De maneira geral, é indispensável a todos os seres vivos. A água é uma necessidade absoluta para nosso bem-estar físico, pois é o único agente natural que podemos utilizar para nossa limpeza pessoal e para nos refrescar. Não foi à toa que, desde os primórdios, os seres humanos procuraram instalar suas moradias junto a rios, nascentes de água ou lagos. As plantas não podem crescer sem, regularmente, receber água, seja através da chuva, do orvalho ou da umidade do ambiente.

Os rios, assim como as veias no corpo, carregam a água, líquido precioso para irrigar a terra, umedecer o ar, dar vida às plantas, abastecer as cidades, matar a sede dos seres que circulam pelo planeta, lavar a sujeira, banhar e limpar os corpos suados do labor diário, refrescar os dias quentes, apagar o fogo que devora florestas, lavouras e cidades. Assim como há veias salientes, visíveis no corpo humano, e veias internas, de grosso calibre e também minúsculas, há rios que correm no interior da Terra, os lençóis freáticos, reservas de água à espera de serem trazidas para fora, de forma natural, ou através de perfurações. Os rios são as veias do planeta Terra, são a sua alma. E, não por acaso, o rio deste capítulo chama-se Almada.

As águas do rio Almada, em grande parte de seu percurso, sofrem agressões provindas dos agrotóxicos utilizados nas lavouras e dos dejetos das cidades por onde passa. Sua proteção depende da conservação do sistema agroflorestal do cacau, já que o rio tem seu curso inteiro na Região Cacaueira e é uma referência cultural importante. Nasce e abraça o município de Almadina e segue beneficiando milhares de pessoas por Coaraci (neste trecho o rio registra a pior qualidade de suas águas), Ibicaraí, Itabuna (não passa por seu território, mas abastece a cidade), Itajuípe, Lomanto Júnior e Uruçuca, até se ligar à lagoa de Itaípe (conhecida popularmente por lagoa Encantada) e desaguar na enseada da Barra, em Ilhéus (http://rioalmada.no.comunidades.net/index.php). 
A economia dos municípios da Bacia Hidrográfica do Rio Almada (BHRA) se baseia na lavoura de cacau que, em sua maior parte, foi plantada no sistema cabruca (plantação do cacau no sub-bosque da mata primária, promovendo um convívio harmônico e duradouro com a natureza), de grande importância ecológica por conservar grande parte das árvores nativas como sombreamento para o cacau. Atualmente, em decorrência da crise regional, tal lavoura corre o risco de ser eliminada pela exploração da madeira dos remanescentes florestais e, posteriormente, substituída por outra cultura ou pela pecuária, em geral, menos conservacionistas que a cacauicultura.

\section{Características gerais}

\section{A Bacia Hidrográfica do Rio Almada (BHRA)}

A BHRA, junto com a bacia hidrográfica do rio Cachoeira que banha outros municípios, constituem a chamada Região Cacaueira, inserida na microrregião Ilhéus-Itabuna (FIGURA 1), é parte integrante da Bacia Hidrográfica do Atlântico Leste. Esta região é historicamente conhecida pela riqueza oriunda da exportação do seu principal produto agrícola: o cacau. Porém, desde 1989, o cultivo do cacau, nesta região, vem sofrendo uma profunda crise, que tem como aspectos característicos básicos a baixa dos preços no mercado internacional, a instabilidade climática que se verificou nos últimos anos e o intenso ataque de uma praga conhecida como "vassoura de bruxa", que devastou grande parte da lavoura cacaueira (FERANDES, 1998).

No topo de uma serra, a Almada-Salomé, no município de Almadina, sob uma lama escura que encobre uma camada de areia, rasgam a terra, de forma borbulhante, as águas que vão dar origem a dois rios: o Salomé, que toma a direção da cidade de Ibicaraí, e o Almada, que desce na direção de Almadina. Este berço, protegido por pouca vegetação que ainda garante sua existência, poderá desaparecer se não forem tomadas medidas urgentes para lhe garantir o direito de continuar sendo o responsável pelo nascimento/renascimento contínuo das águas que dão origem a esses rios (observação da autora in loco, em pesquisa de campo, 1995).

O relevo da bacia percorrido pelo rio Almada é montanhoso e escarpado a oeste, onde se localizam as principais serras da região: Pereiro, Cordilheira Pelada, Domingos do Corcovado, Santa Izabel, da Bandeira, dos Macacos, Fala Homem e a do Almada-Salomé, com altitude máxima de $670 \mathrm{~m}$. Na parte central, nordeste e sudoeste, o relevo se apresenta ondulado e suave ondulado. Junto à foz, em Ilhéus, o relevo se apresenta sob uma estreita faixa plana. 
FIGURA 1 - Bacia Hidrográfica do Rio Almada (BHRA), sul da Bahia

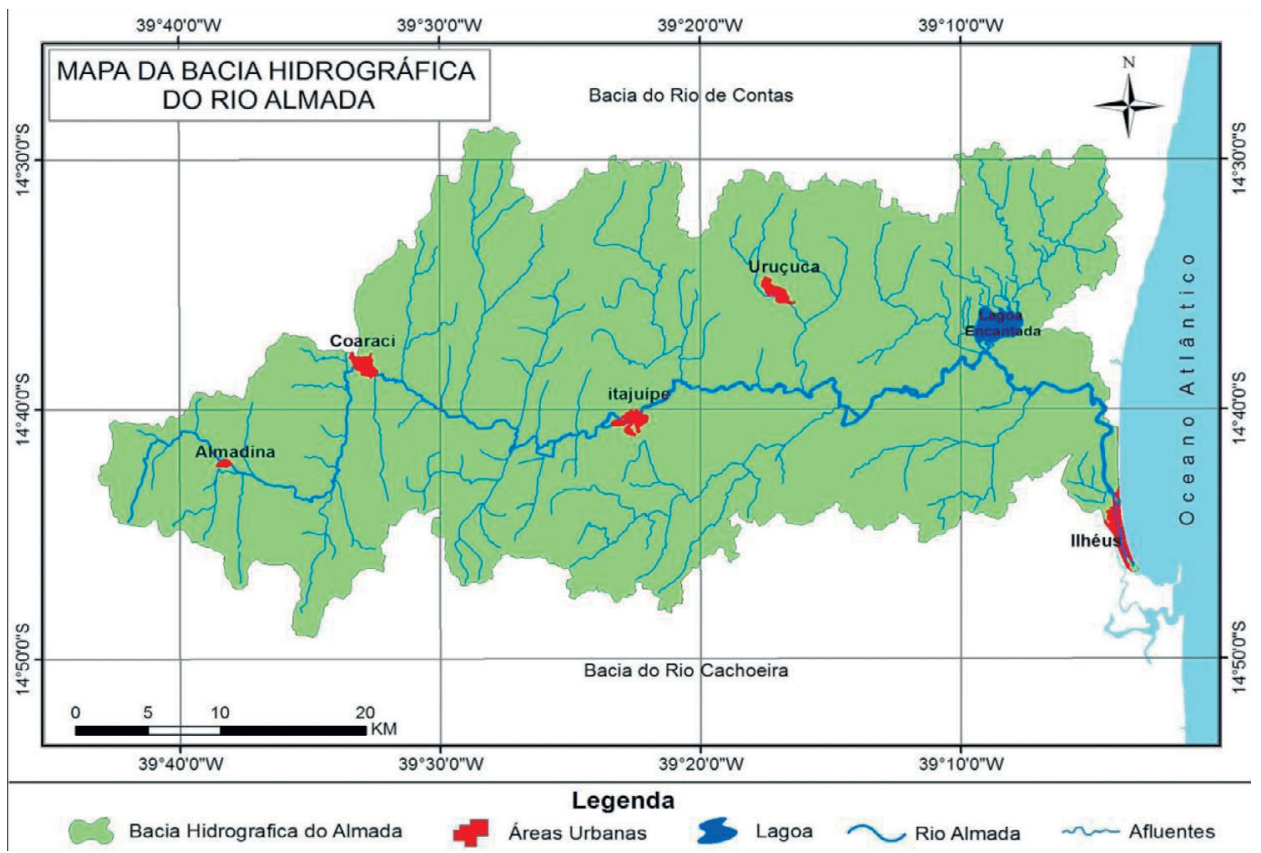

Fonte: Laboratório de Análise e Planejamento Ambiental (LAPA/UESC).

Nota: Elaboração de Cristiano Marcelo Souza, 2011.

O solo, se não é o elemento mais evidente da paisagem, é o mais típico porque reflete, geralmente, de maneira bastante fiel, a interação dos diversos componentes do meio físico (rocha, clima, relevo, organismos e tempo). Baseando-se no levantamento dos solos da Região Cacaueira baiana, ao nível dos grandes grupos, realizada pela CEPLAC (1976), podem-se destacar, em linhas gerais, os solos da BHRA, em: solos podzólicos (terço superior e terço médio); solos latossólicos, orgânicos e de areais quartzosas (terços médio e inferior).

O clima da região percorrida pelo rio Almada é do tipo tropical úmido, com médias térmicas em torno de $23^{\circ} \mathrm{C}$ a $25^{\circ} \mathrm{C}$, sendo os meses mais quentes os de outubro a abril, e os menos quentes, de julho a agosto. As características climáticas da região, em geral, alteram-se no sentido leste-oeste. A própria vegetação nativa indica que, na extremidade leste (zona costeira), é do tipo higrófila, enquanto na extremidade oeste (zona de planalto) já apresenta características de caatinga ou de mata cipó.

Como em grande parte das bacias hidrográficas brasileiras, a vegetação do BHRA se encontra bastante alterada. O cultivo do cacau e as pastagens 
substituíram as áreas inicialmente cobertas por floresta perenifólia higrófita e ribeirinha. Também formações secundárias de capoeira substituíram a vegetação original. De acordo com Santana; Melo e Leão (1986), a capoeira é formada por árvores de pequeno diâmetro, variando da forma arbórea à arbustiva, destacando-se a umbaúba, a coarana e a corindiba.

Ao longo do rio, nas áreas mais alagadas e úmidas, encontra-se o mangue doce, constituído, principalmente, de arruda e aninga. Nos locais onde a velocidade da água é pequena, encontram-se "ilhas" de macrófitas, destacando-se a baronesa (aguapé) e a alface d'água. Entre Sambaituba e a foz, observa-se a presença do "mangue doce", que vai sendo substituído pelo mangue salgado nas áreas onde a influência da salinidade é mais constante. Junto à foz, nos cordões arenosos, encontram-se grandes extensões de coco-da-bahia. Segundo o Plano Piloto do Município de Ilhéus (PLAMI, 1969), estas áreas de restinga existem ligeiramente acima das marés altas atuais $(1,5$ a $2,0 \mathrm{~m})$. As áreas de restinga se encontram muito alteradas, ocupadas por empreendimentos turísticos, condomínios e residências (ROCHA; AZEVEDO; CARMO, 1995).

\section{O rio Almada}

O rio Almada, com uma extensão de 94 quilômetros, espinha dorsal da bacia de mesmo nome, situada no sul da Bahia, limita-se ao norte e ao sul com as bacias hidrográficas do rio das Contas e do rio Cachoeira, respectivamente. A leste descortina-se o Atlântico. Esta bacia, localizada entre os paralelos $14^{\circ} 26^{\prime}$ e $14^{\circ} 5^{\circ}$ sul e os meridianos $39^{\circ} \mathrm{O} 3^{\prime}$ e $39^{\circ} 44^{\prime}$ oeste, é um dos importantes sistemas naturais da região sul da Bahia, já que as principais cidades da região estão situadas nela ou pelo fato de se utilizarem de suas águas nas atividades econômicas, domésticas e culturais (Itabuna não é banhada pelo rio, mas se abastece dele). O rio que atravessa a cidade é o Cachoeira, cujas águas não são utilizadas para consumo.

O rio Almada, em toda sua extensão, percorre a Região Cacaueira desaguando na Enseada da Barra, em Ilhéus. Em 2003, pelo Decreto Estadual n. ${ }^{\circ} 8.650$, de 22/09/2003, tornou-se uma Unidade de Conservação Estadual, com o decreto de ampliação da Área de Proteção Ambiental da Lagoa Encantada (Decreto Estadual n. ${ }^{\circ}$ 2.217, de 14/07/93), que tem como gestor o Estado, através da Secretaria de Meio Ambiente e Recursos Hídricos (SEMARH). Uma parceria com a Associação Brasileira de Apoio aos Recursos Ambientais (ABARÁ) viabilizou a criação de seu Conselho Gestor, com participação dos mais diversos setores da sociedade. 
Dentre os afluentes do Almada destacam-se, à margem direita, os ribeirões dos Macacos e do Boqueirão, o riacho Sete Voltas e o rio Tariri. À margem esquerda, os rios São José, Braço do Norte, De Jussara, Vai-QuemQuer, Comprido e o canal da Lagoa de Taípe ou Lagoa Encantada.

No curso inferior, o rio Almada, antes de desembocar no mar, em Ilhéus, percorre uma depressão cujos bordos possuem declividades variáveis. Ao norte dessa depressão encontra-se a lagoa Encantada. A sudoeste e a oeste da lagoa, as encostas sobem abruptamente, através de uma rede de elevações acentuadas. A noroeste, os contornos da zona baixa alagadiça estão em contato com uma faixa de relevo ondulado. A leste, a depressão se fecha e o rio Almada cruza um estreitamento dos bordos, formados por colinas mamelonizadas e, finalmente, entra na planície costeira (ROCHA; AZEVEDO; CARMO, 1995).

Para o interior, o rio Almada percorre um trecho de ondulações em forma de escudos, separados por vales largos e chatos. Nos limites ocidentais de Ilhéus, próximo à confluência com o rio do Braço, o modelado se movimenta e sobe para o sul, formando uma área de elevações fortes, quase montanhosas, com depressões, onde apontam matacões ou bolsas de rochas graníticas de vários metros de diâmetro. Na barra do rio Almada, um pontal arenoso encontra-se em construção acelerada, ameaçando fechar a sua foz.

O traçado do rio Almada é tortuoso, apresentando numerosos meandros. No trecho em que percorre áreas do município de Ilhéus meandra em planícies aluviais, estreitando-se somente no setor que antecede a sua saída na depressão circunvizinha à lagoa Encantada. A largura da depressão oferece as condições para o espraiamento das enchentes. Nela, os problemas ligados às inundações se restringem a um acréscimo de extensão de terrenos alagados, nas proximidades dos distritos de Castelo Novo e Sambaituba, com repercussão na área do litoral, a norte de Ilhéus (CEPLAC, 1976).

Em sua caminhada em direção ao mar, receptáculo de suas águas já cansadas e poluídas, o Almada passa por várias cidades que o tornam o transporte de seus dejetos.

Almadina, nascida de seu nome, dista aproximadamente 455 quilômetros da capital, Salvador. O rio Almada nasce em suas terras e, já, ao passar pela cidade, está bastante poluído. Resumindo os depoimentos verbais de moradores colhidos em 1995, em Almadina, para a elaboração da monografia Caracterização Ambiental da Bacia do Rio Almada (Sul da Bahia) - aspectos socioambientais (ROCHA; AZEVEDO; CARMO), temos a seguinte fala: "Crianças mergulhavam em lugares onde hoje não há mais que meio metro de água”. Para ligar uma margem à outra, dentro 
do perímetro urbano, na década de 1950 foi construída "Uma ponte sobre o rio Almada, que hoje é uma ponte sobre um mero riacho" (depoimento do "seu" Zé). Continuando a falar sobre as mudanças, o morador conclui:

Olhem os nossos morros, os morros que circundavam Almadina. Vejam como se encontram. Aqui, o desmatamento predatório, criminoso, deixou nossas montanhas desnudas. Antes, era lindo ver os ipês amarelarem o verde da montanha (FIGURA 2).

FIGURA 2 - Almadina: região de Sete Paus - berço do rio Almada

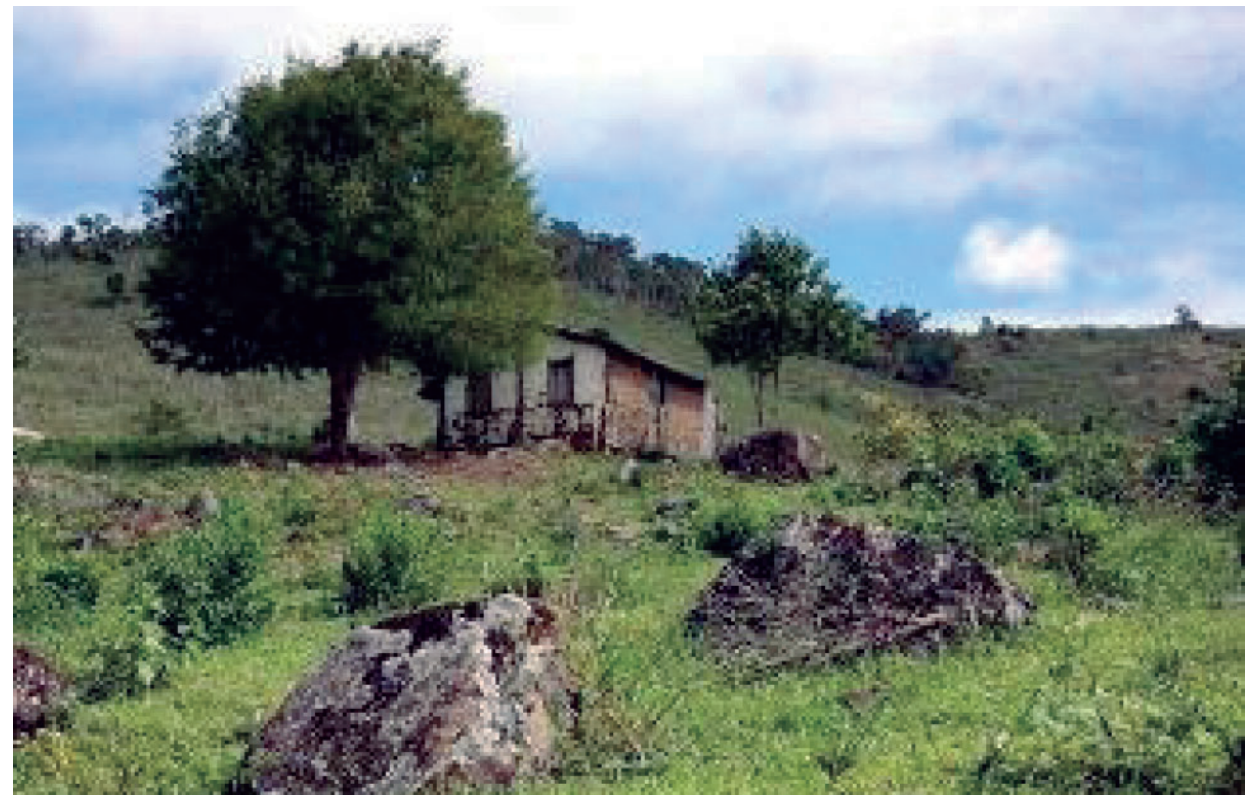

Fonte: <http://acordameupovo.blogspot.com>.

Nota: Fotografia Marcos Souza, 2008.

O município de Coaraci, até 1919, era encoberto por matas inexploradas, com plantações de cacaueiros e pequenas pastagens, e o rio Almada corria por lá fagueiro e garboso. Hoje, segundo um dos moradores entrevistados para o projeto citado à página 63:

É um esgoto a céu aberto. O rio foi responsável pelo surgimento das cidades do cacau. Agora está sendo destruído sem dó nem piedade." [Outro morador acrescenta:] "O rio Almada não é mais um produtor de riqueza, pois foi transformado num ribeirão, ribeirão do Almada [FIGURA 3]. É pena que meus filhos não possam herdar o rio Almada como eu herdei de meus pais. 
FIGURA 3 - Coaraci: sem a mata ciliar, o rio Almada agoniza

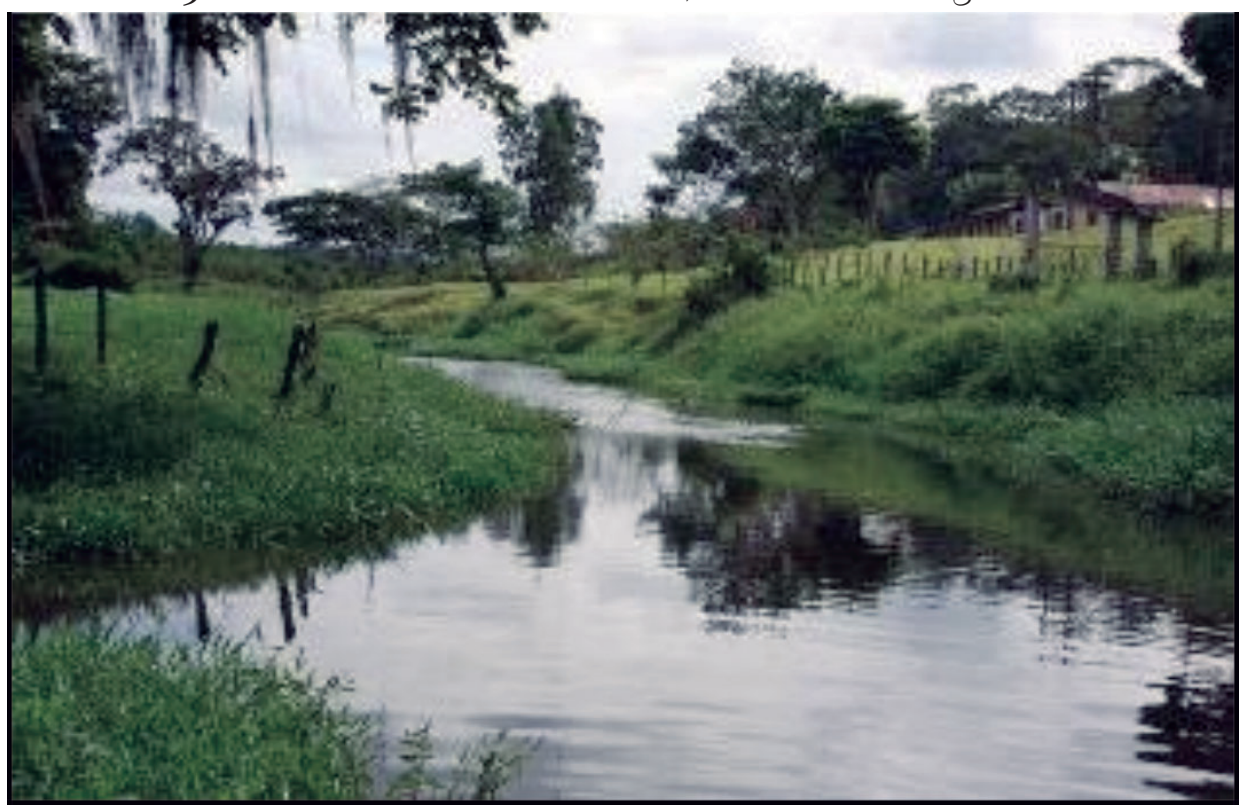

Fonte: $<$ http://acordameupovo.blogspot.com $>$.

Nota: Fotografia Marcos Souza, 2008.

Itajuípe é abastecida com a água do rio Almada, captada à altura de Três Paus, na sede do município. Ao atravessar a cidade, suas águas, em adiantado processo de eutrofização, estão poluídas, com lixo acumulado no leito e nas margens. Segundo informações de seus moradores, a poluição do rio Almada, ao atravessar as terras do município, dá-se, basicamente: a) pelo uso de agrotóxicos; b) pelo esgoto da cidade lançado em suas águas; c) pelo aterro sanitário nas margens e no leito do rio; d) pela inexistência da mata ciliar, assoreando o leito (FIGURA 4). 
FIGURA 4 - Itajuípe: apesar do esgoto, o rio Almada se renova

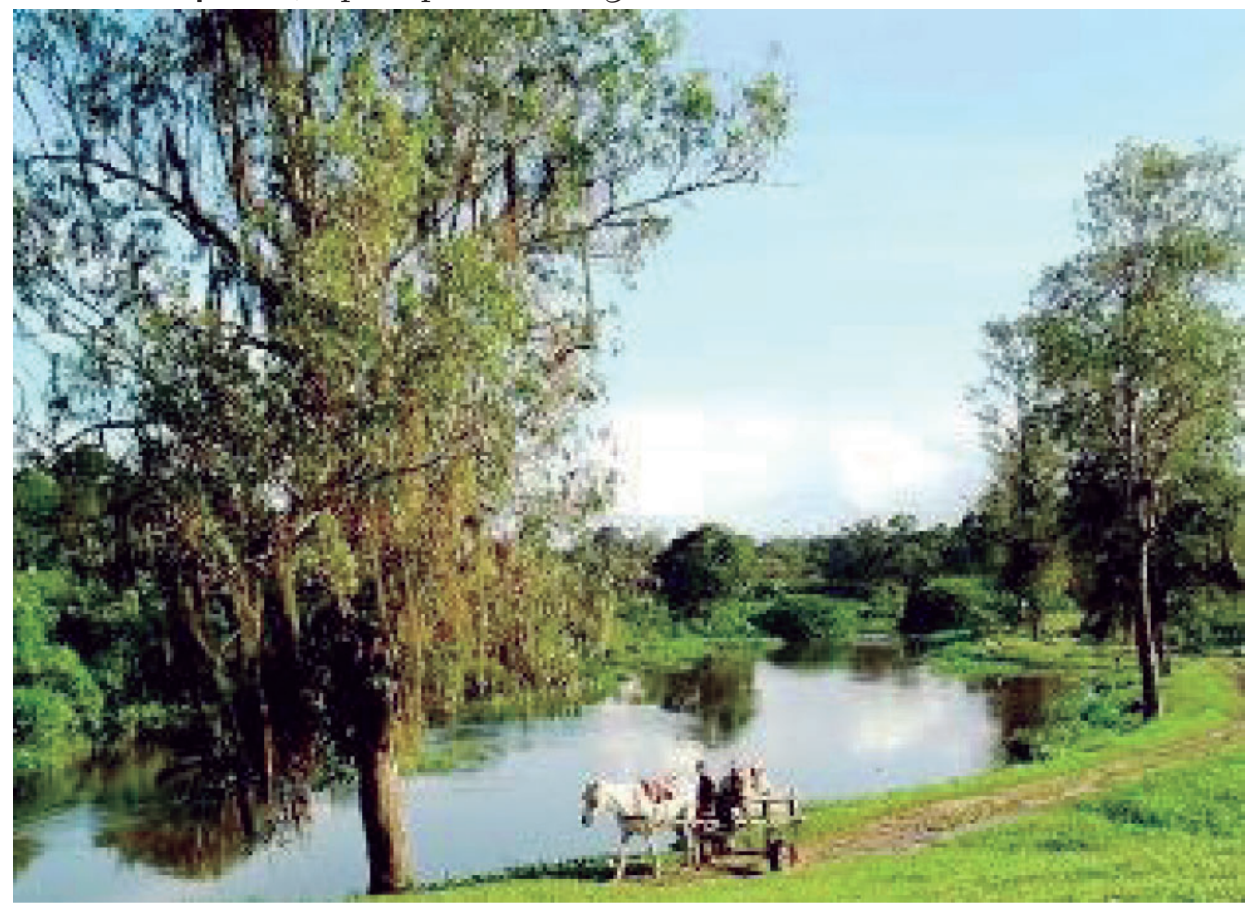

Fonte: http://acordameupovo.blogspot.com

Nota: Fotografia Marcos Souza, 2008.

Em Uruçuca, a água que abastece a cidade é captada de um dos afluentes do rio Almada, visto suas águas estarem em alto grau de eutrofização.

As águas do rio Almada, em Ilhéus, não são utilizadas para consumo, pois chegam com alta carga de poluição. O rio, ao atravessar as cidades já mencionadas, vai acumulando toda sorte de detritos jogados em seu dorso e em suas profundezas, que já não tão profundas assim, para que sejam despejados no mar. Suas águas, que deveriam chegar esfuziantes, pois estão chegando a seu destino final, para sua purificação e reinício de todo o ciclo, através da evaporação, chegam engrossadas pelo esgotamento sanitário, por detritos. Contudo, passa por momentos felizes, ao atravessar a mata que protege as lavouras de cacau.

Em Aritaguá, distrito situado na zona norte de Ilhéus, metade dos esgotos domésticos é lançada diretamente no rio Almada. Outros $25 \%$ vão para os quintais das casas e, fatalmente, também contaminam o rio. O restante segue para fossas sépticas. Apesar disso, ele continua bravamente sua caminhada, renovando-se um pouco ao atravessar as matas que protegem o cacau e, aliviado, joga-se ao mar, túmulo e berço de renovação de suas águas (FIGURA 5). 
FIGURA 5 - Ilhéus: o rio Almada fortalecido pela Mata Atlântica e as árvores das fazendas de cacau

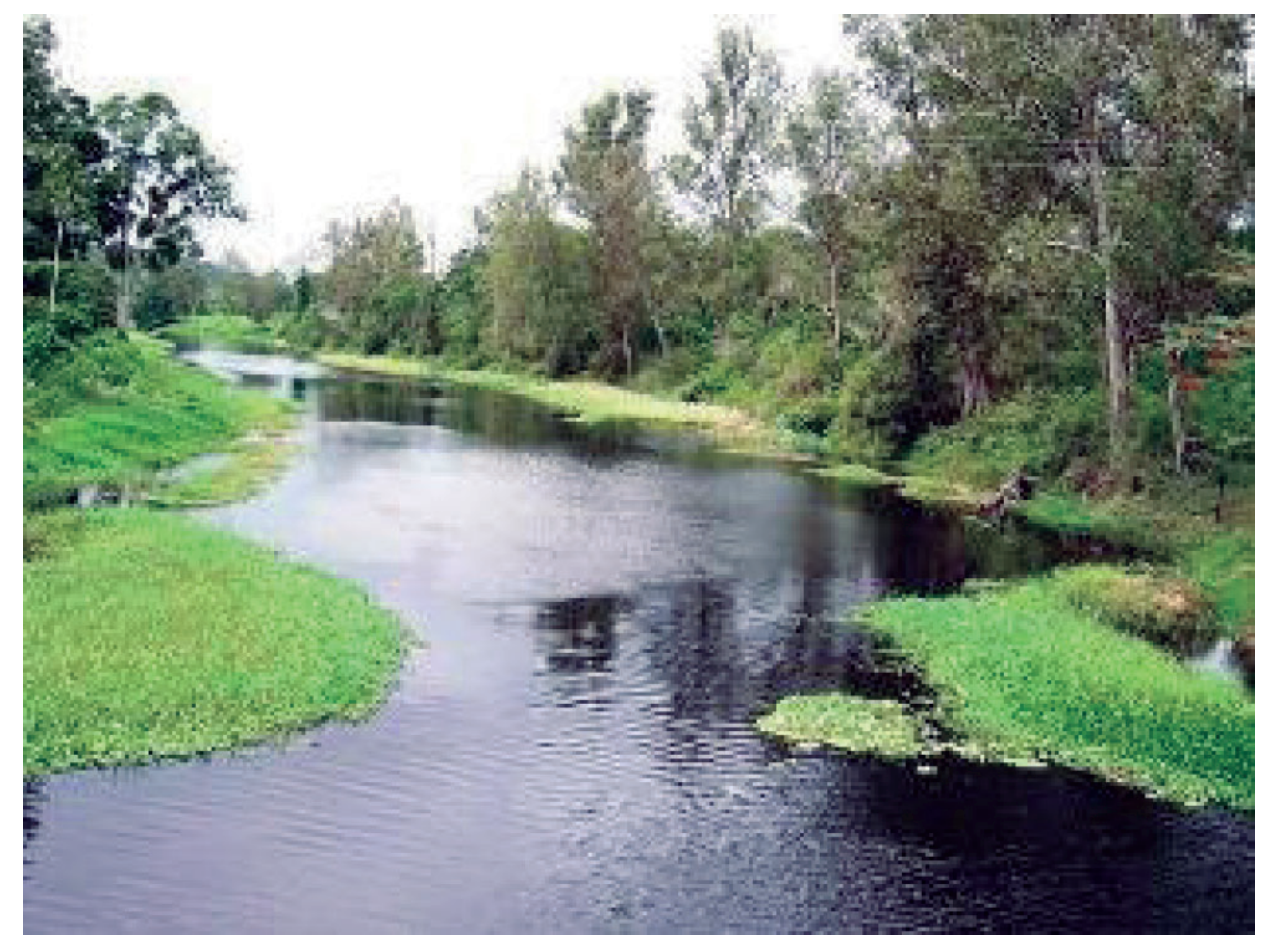

Fonte: $<$ http://acordameupovo.blogspot.com>.

Nota: Fotografia Marcos Souza, 2008.

Em Barro Preto, a captação de água para consumo é feita na Serra da Palha, em um local denominado de "Pedra Lascada". Nesse município, o rio Almada não sofre agressões tão drásticas. Isso se deve a que o rio corre fora da área urbana.

Um estudo feito pelo CEPEMAR (1990) chamava a atenção sobre os impactos socioeconômicos decorrentes de se implantar a captação de água do rio Almada, no distrito de Castelo Novo, para abastecer a cidade de Itabuna. Esses impactos incidiram sobre os municípios da sua bacia e, mais diretamente, sobre as populações dispersas ao longo do trecho que o rio percorre no município de Ilhéus, a jusante de Castelo Novo. A hipótese dos impactos:

Baseia-se no aspecto de que, quaisquer repercussões sobre o rio Almada afetarão as populações envolventes, quer seja mediante alterações introduzidas no ecossistema e, consequentemente, nos modos de vida, quer através das restrições 
que poderão ser impostas ao aproveitamento do rio, em suas várias modalidades: fonte de água (consumo humano e não humano), fonte de transporte, de subsistência econômica direta (captação de peixes e moluscos) e indireta (produção agrícola e pecuária) que igualmente poderão ser atingidas (CEPEMAR, 1990, p. 80).

É importante ressaltar que as populações se formaram ao longo da BHRA, tanto espacial, quanto economicamente. As atividades produtivas se adaptaram às características do ecossistema, incluindo o rio. Ecológica e culturalmente, as populações, ao longo da sua bacia, estão ligadas ao rio Almada e dele dependem, visto que se dedicam à pesca, ao uso da água para suas necessidades diárias, usam-no como para transporte, lavagem de roupa, banho, etc. Contudo, algumas comunidades não consomem a água do rio, por considerarem-na inadequada, como é o caso das populações dos distritos de Aritaguá, Sambaituba, Sequeiro Grande, entre outros. Servem-se de água de "bicas", nascentes e pequenos córregos que, frequentemente, localizam-se em fazendas de particulares. A justificativa para não consumirem a água do rio é a poluição devido ao constante despejo de dejetos domésticos, deixando-a com a cor escura. A diminuição, nos últimos anos, do volume de água do rio Almada é atribuída, principalmente, ao desmatamento das cabeceiras. Este desmatamento foi constatado in loco, apesar de, no alto da serra, onde as águas dão origem ao Almada, a mata ainda ser relativamente fechada. Mas, nas proximidades, ela deixou de existir há mais de 60 anos, conforme testemunho dos moradores que lá nasceram e já ultrapassaram os 70 anos de idade.

Os nativos olham para o futuro com temor, ciosos de sua dependência do rio, e da responsabilidade que lhes caba em conservá-lo, conforme afirmaram os entrevistados citados na página 63: "A beira do rio hoje é manga de gado. Esqueceram que os brejos, as beiras do rio é onde o peixe desova, não pode desmatar. Acaba o brejo, onde o peixe vai criar? Tem que prevenir o futuro". A professora e poetisa Claudia Pereira Santos Castro (CASTRO, 2011) resume a situação do rio com seus versos: 


\section{O Almada}

Ele nasce em Almadina,

Menina.

Dizem que vem das almas,

Que nada!

Surgiu quando o homem

Sentia da floresta o rebentar

Da alvorada.

Quando penso nesse rio,

Rio...

Sorrio e falo

Agora é desafio

Sua água tá que nem fio,

Tá da cor de nada.

Ai que vontade de salvar o

rio Almada!

[...]

Fonte: Blog Ligação direta, o7/o2/2011.

\section{Uso das terras na Bacia Hidrográfica do Rio Almada (BHRA)}

O espaço ocupado pelas atividades agrícolas da BHRA é significativo, desenvolvendo-se nele uma agricultura voltada para as demandas dos mercados externos e uma pequena policultura distribuída por toda área: tradicionais cultivos de subsistência, monocultura do cacau, especiarias, cultivos exóticos que atendem a uma demanda externa, pastagem extensiva, silvicultura, entre outros.

Estes cultivos, bem como as pastagens, do ponto de vista da área ocupada substituíram, de leste para oeste, a floresta, inclusive a faixa também conhecida como Mata Atlântica. Exceção é feita por manchas significativas, na maioria das vezes, protegidas por leis sob a forma de Unidades de Conservação (UC).

A cobertura vegetal se encontra reduzida a pequenas manchas na Mata Atlântica, na sua maior parte descaracterizada, mantida como suporte do cacau. De modo geral, predomina a vegetação secundária, que ocupa extensões significativas em diversos estágios de regeneração.

Na faixa litorânea, os ecossistemas costeiros vêm sofrendo a ação predatória, principalmente os manguezais, utilizados como depósito de lixo. 
Em alguns trechos, verificou-se a devastação da vegetação e do aterro, devido à expansão urbana.

Os mangues se constituem em um dos ecossistemas costeiros de maior produtividade, típico das zonas tropicais, resultantes dos processos de acumulação flúvio-marinha, localizados, geralmente, nos deltas dos rios. Esse ambiente é povoado por uma vegetação de florestas halófilas, bastante peculiar, com alta densidade e pouca variação de espécies, tolerância aos altos teores em sal e baixas concentrações de oxigênio. Além disso, o sistema é alimentado pelas marés altas que alagam os mangues, trazendo material orgânico e argila em suspensão, os quais entram na cadeia alimentar costeira, criando um ambiente favorável ao desenvolvimento de várias espécies. Assim, os manguezais são hospedeiros de uma fauna rica, povoada, principalmente, por moluscos e crustáceos, servindo, ainda, de refúgio para várias espécies marinhas, principalmente na fase de reprodução, constituindo-se em ambiente vital para a manutenção da atividade pesqueira.

Pode-se observar a degradação dos manguezais no litoral de Ilhéus, seja pela poluição causada pelo esgotamento sanitário, desmatamento indiscriminado, aterros para a expansão urbana, seja pelo uso predatório realizado pela população carente, ou mesmo pelos empreendimentos turísticos.

Faz-se necessária a tomada de consciência quanto à importância biológica do mangue para a economia pesqueira, sobretudo considerando-se que representa uma grande fonte de alimentos para a população litorânea.

Dentre as atividades agrícolas desenvolvidas nessa região, o cacau se destaca como uma das principais culturas comerciais, com importante desempenho na economia, porém, em decadência, com algumas plantações abandonadas, devido às pragas que vêm dizimando essa cultura, principalmente o fungo moniliophtora perniciosa, mais conhecido como "vassoura-de-bruxa". O desmatamento da Mata Atlântica está em processo acelerado, apesar de a legislação proibir o desmatamento e disciplinar o uso de seus recursos.

Em toda a área da BHRA se desenvolve o cultivo de cacau, com sombreamento de mata raleada e/ou plantações de banana. Em menor escala, pastagens, piaçava, seringueiras e culturas de subsistência. A noroeste de Coaraci se encontram pastagens extensivas, com testemunhos de floresta perenifólia, associada às culturas de cacau, cravo, seringueira e culturas de subsistência. A área da lagoa Encantada se constitui numa Área de Proteção Ambiental (APA), a qual abrange o litoral norte do município de Ilhéus, além dos municípios de Uruçuca, Itajuípe, Coaraci e Almadina, no litoral sul da Bahia, com uma área de 157.745 ha. A lagoa Encantada, que dá nome à APA, é formada dos rios Pipite e Caldeiras, e forma um 
conjunto harmônico com beleza e exuberância da Mata Atlântica. Além da floresta, cachoeiras, nascentes e cavernas, a APA abrange uma área litorânea onde são encontradas restingas e manguezais. Diversas reservas particulares estão implantadas ou em fase de implantação.

Paralelamente às atividades agropastoris mencionadas, outras se destacam com desempenho importante na economia local e regional, como o setor industrial, representado por distritos industriais de Itabuna e Ilhéus.

\section{Conclusão}

Toda a vida no planeta Terra se resume em seus quatro elementos: fogo, ar, água e terra. A ciência geográfica, em sua trajetória, andou por vários caminhos, por várias geografias, passando pelo fogo das experiências, planando em ares os mais diversos, respirando fundo, sem pouso certo, purificando-se e se renovando nas águas de novas descobertas e pousando na terra, onde vivem os homens, nos mais diversos meios, nos mais variados territórios, construindo, reconstruindo, imaginando novos lugares, novas paisagens, debatendo-se num emaranhado infinito de relações sociais, políticas, econômicas, culturais e religiosas. Nessa caminhada, é claro, também tenta relacionar-se de maneira harmônica com a Mãe Terra. Estes mesmos elementos podem ser vistos em devaneios, de forma intimista, conforme Clauhs (2008, p. 52), já que somos seres duais:

\section{Elementos}

Nascemos para vencer obstáculos Enfrentar as brasas ardentes sob os pés E chamuscar a vida com amor ante o revés.

Fogo.

Vivemos para distribuir alegrias, Insuflar aromas doces pelos pulmões, E oxigenar a luz que aviva os corações.

Ar.

Morremos para nos aproximarmos da fonte divina, Inundar com gotas de mel lábios ressecados, $\mathrm{E}$ adoçar o sangue que nos mantém alimentados.

Água.

Renascemos para provar a nós mesmos

Que viver é moldar a areia granulada

E retornar ao lar do Pai após curta temporada.

Terra. 
Assim, o rio Almada, cuja alma foi desnudada nesse estudo, precisa de proteção para que sua caminhada prossiga sem percalços, alimentando a terra com sua umidade, abrigando a vida que nele se desenvolve, respirando o ar puro à medida que serpenteia pela Mata Atlântica, devolvendo umidade à atmosfera a fim de se transformar, novamente, em gotas que formam as nuvens que, quando saturadas, caem em forma de chuva e voltam novamente ao leito, num abraço carinhoso das águas que ali ficaram à sua espera para prosseguir na caminhada que é eterna enquanto durar.

A proteção do rio Almada e de seu entorno depende da tomada de consciência da população que vive em seu entorno, pois é nítida a fragilidade ambiental. À medida que há mudança de uso e ocupação em sua bacia, altera-se o grau de fragilidade, em função da dinâmica de ocupação, requerendo, portanto, como já foi afirmado anteriormente, conscientização de todos, através da educação ambiental. 


\section{REFERÊNCIAS}

CASTRO, C. P. S. Poema sobre Rio Almada ganha prêmio em Salvador. In: http://noticiasligacaodireta.blogspot.com.br, 7/2/2011.

CEPEMAR - SERVIÇO DE CONSULTORIA EM MEIO AMBIEMTE LTDA. Estudos de avaliação ambiental da área sob influência da captação d'água do rio Almada. Ilhéus: Prefeitura Municipal de Ilhéus, 1990. (Relatório Técnico)

COMISSÃO EXECUTIVA DO PLANO DA LAVOURA CACAUEIRA (Ceplac). Diagnóstico socioeconômico da região cacaueira: recursos hídricos. Ilhéus: CEPLAC, 1976. v. 5.

CLAUHS, A. R. Elementos. Revista O Rosacruz, n. 263, p. 52. Curitiba: Grande Loja de Língua Portuguesa, $1^{\circ}$ trimestre, 2008 .

FERANDES, A. S. A. Manejo integrado da bacia hidrográfica do rio Almada. São Paulo, [200-?]. Disponível em: <http:// www.eaesp.fgvsp.br>. Acesso em: 4 jul. 2011.

PLANO PILOTO DO MUNICÍPIO DE ILHÉUS (PLAMI). Rio Almada. llhéus, 1969. Disponível em: <http://rioalmada. no.comunidades.net/index.php>. Acesso em: 17 nov. 2010.

ROCHA, L. B.; AZEVEDO, S. M. M. M.; CARMO, W. P. Caracterização ambiental do rio Almada (sul da Bahia): relações socioambientais. 1995. Trabalho de Conclusão de Conclusão de Curso (Especialização em Desenvolvimento e Gestão Ambiental)- Universidade Estadual de Santa Cruz, Ilhéus, 1995.

SANTANA, S. O.; MELO, A. A. O.; LEÃO, A. C. Levantamento semidetalhado dos solos do município de Itajuípe. Ilhéus: CEPLAC, 1986. (Boletim Técnico 142). 


\section{O PROCESSO DE}

METROPOLIZAÇÃO

DO TERRITÓRIO

BRASILEIRO:

\section{uma abordagem para ampliar \\ o debate no ensino de \\ Geografia}

\section{Gilmar Alves Trindade}

\section{INTRODUÇÃO}

A partir da década de 60 do século XX significativas transformações alteraram os conteúdos da urbanização brasileira, redimensionando fluxos migratórios associados, principalmente, ao processo de industrialização. A relação campo-cidade se tornou ainda mais interdependente e algumas cidades, principalmente capitais estaduais, conheceram um crescimento demográfico e uma expansão espacial bastante acelerada.

Neste contexto, por determinação do governo federal, ocorre a institucionalização de nove regiões metropolitanas no Brasil, a fim de se promover uma melhor gestão do território. Após a Constituição de 1988, novas regiões metropolitanas foram criadas, atendendo agora à determinação dos governos estaduais. Trata-se de um processo em pleno desenvolvimento, que tende a promover transformações em todas as escalas de gestão do território, alterando a forma e a dinâmica da rede urbana brasileira.

No âmbito dessa recente metropolização do território, entretanto, há alguns fatores que devem ser analisados e discutidos, pois se relacionam a uma nova dinâmica espacial cujas causas e efeitos ainda não estão completamente revelados. Esse texto discute alguns desses fatores, buscando introduzir alunos e professores da educação básica no âmbito dessa questão intrinsecamente associada à urbanização brasileira na contemporaneidade. 


\section{O PROCESSO DE METROPOLIZAÇÃO DO TERRITÓRIO BRASILEIRO}

A urbanização brasileira conheceu significativas transformações na segunda metade do século XX. Inicialmente, a partir da década de 1960, o país passou de uma sociedade rural-agrária para uma sociedade urbano-industrial. Movimentos migratórios intensos redesenharam a organização espacial brasileira, especialmente aqueles relacionados ao adensamento populacional nas grandes cidades da região Sudeste, em função dos fatores de atração relacionados à industrialização e à oferta de bens e serviços inexistentes ou escassos em outras regiões do país.

Muito rapidamente, algumas cidades brasileiras, como São Paulo, Rio de Janeiro e Belo Horizonte, registraram um intenso crescimento demográfico, que foi acompanhado pela expansão do espaço urbano e por uma série de problemas relacionados a este crescimento, como: ocupação desordenada do solo urbano, falta de moradias populares, desemprego e violência urbana; ou seja, as cidades tiveram um crescimento descontrolado sem a devida contrapartida em infraestrutura e serviços urbanos, fundamentais à garantia das condições mínimas necessárias à sobrevivência.

Se até a década de 1970 o processo brasileiro de urbanização se caracterizava, espacialmente, pela concentração demográfica mais acentuada nas áreas próximas ao litoral, seguindo a tendência histórica de ocupação e povoamento do território, em fins dos anos 1970 e início da década de 1980 novas tendências de crescimento demográfico definiram um novo padrão de organização do espaço, inclusive, com a multiplicação de cidades com mais de 100.000 habitantes.

No bojo daquelas tendências de rearranjo espacial no Brasil, a partir dos anos 1980, pelo menos dois fatores devem ser destacados, pois estão intrinsecamente associados a esta nova lógica de urbanização do território:

1. a expansão da fronteira agrícola em direção ao interior das regiões Centro-oeste, Nordeste e Norte do Brasil, provocada, principalmente, pelas atividades produtivas relacionadas ao agronegócio da soja; este movimento redundou em significativo crescimento demográfico no Mato Grosso e no oeste da Bahia, por exemplo;

2. a desconcentração industrial, fenômeno marcado pela distribuição de unidades fabris em diferentes regiões do território brasileiro, interior de São Paulo, Paraná, Minas Gerais e Santa Catarina; capitais estaduais e cidades médias no interior do Nordeste brasileiro; Cuiabá, Goiânia e interior de Goiás; entorno de Manaus 
e Belém, entre outros lugares. Vale lembrar que o processo de desconcentração industrial está intimamente associado às políticas de concessão de benefícios e de incentivos fiscais, responsáveis pela atração de indústrias para determinadas regiões do país em detrimento de outras tantas regiões, caracterizando o que se convencionou chamar de "guerra dos lugares" (CARLOS, 1996; SANTOS, 1999).

Nesse contexto, entre as décadas de 1960 e 1970, o processo brasileiro de urbanização foi caracterizado por uma nova dinâmica urbana relacionada à gestão do território através da criação de regiões metropolitanas, na medida em que a expansão horizontal das grandes cidades, especialmente das principais capitais estaduais, levaria suas manchas urbanas a se conurbarem com os espaços das cidades contíguas aos seus territórios. As transformações políticas, econômicas e sociais daquele período exigiram uma nova interpretação da realidade urbana brasileira, que incluía, necessariamente, a consideração das metrópoles, das regiões metropolitanas e de seus espaços conurbados, associados, evidentemente, aos fluxos e articulações responsáveis por essa nova organização socioespacial. Na realidade,

As regiões metropolitanas apresentam-se, fundamentalmente, como grandes conurbações urbanas, provocadas pela expansão territorial de municípios vizinhos e, principalmente, pela comunicação econômico-social entre as cidades, o que gera questões de ordem comum (GUIMARÃES, 2004, p. 1).

Muitas vezes, a paisagem urbana denuncia um espaço metropolitano conurbado; outras vezes, essa identificação não é, a priori, possível, pois, em alguns casos, há resquícios rurais entre as cidades que compõem a região metropolitana. Gradativamente,

A expansão das grandes cidades e de suas crescentes áreas de influência iniciaram uma mudança que passou de lugares e padrões de vida dominantemente rurais para predominantemente urbanos (CLARK, 1985, p. 61).

As regiões metropolitanas são áreas heterogêneas no território brasileiro, com características e ritmos diferenciados, com alocação de capital mais volumosa em umas que em outras e com fluxos de densidade as 
mais variadas, já que resultam de processos sociais, econômicos e políticos particulares, apesar de pertencerem a uma mesma unidade nacional de dimensões continentais, como é o caso do território brasileiro. Regiões metropolitanas como as de São Paulo (FIGURA 1) ou do Rio de Janeiro têm conteúdos históricos e geográficos bem diferentes daqueles existentes nas de Recife ou Salvador, por exemplo.

FIGURA 1 - O centro da metrópole paulistana

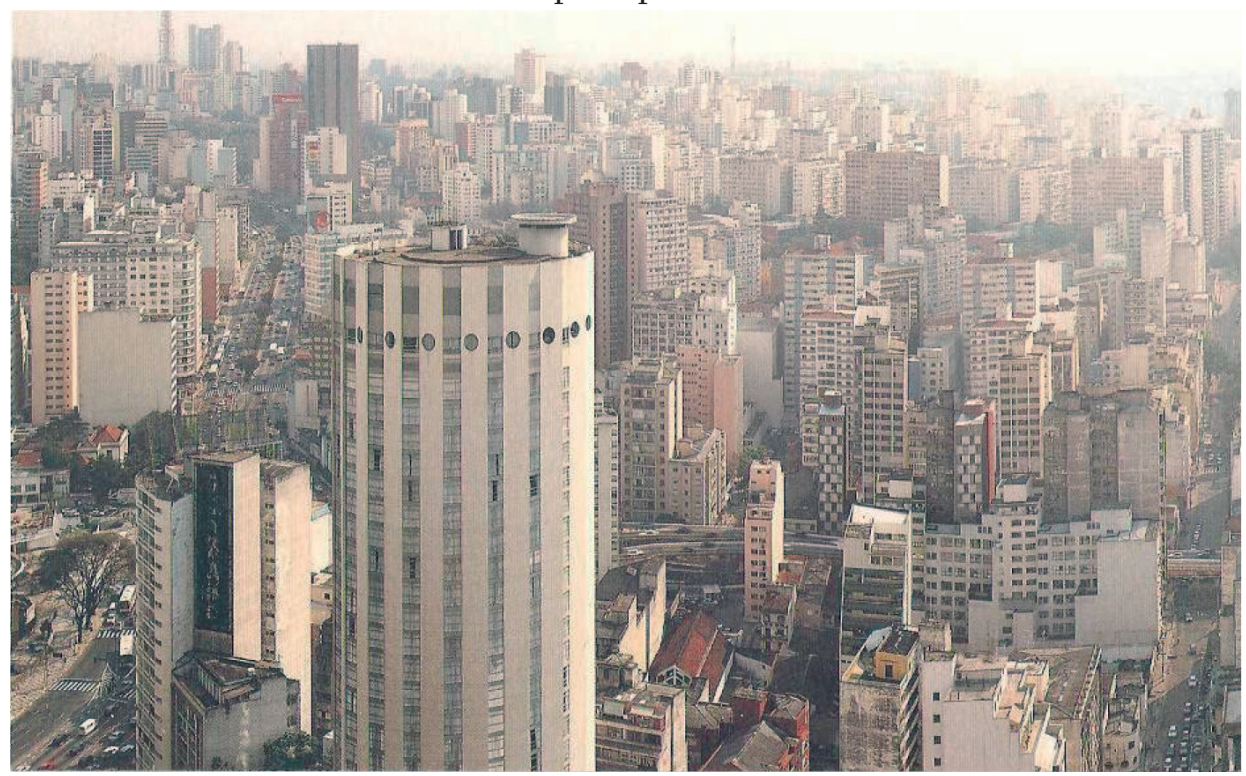

Fonte: Pinacoteca de São Paulo (2004).

Para Guimarães (2004) as regiões metropolitanas apresentam um município central, ao redor do qual gravitam os demais municípios circundantes, motivados pela intensidade econômica e social desenvolvida naquele polo de atração; sendo assim, o município central, como regra, torna-se a sede da região metropolitana. Concordamos com a autora em relação à polarização que o centro metropolitano exerce sobre sua hinterlândia, no entanto, consideramos que o conceito de cidade é mais apropriado que o de município para tratar da centralidade e das articulações que envolvem a análise dos espaços metropolitanos, na medida em que é o espaço da cidade que comanda os fluxos que circulam na região metropolitana, e não o do município.

Pode-se considerar que o fenômeno metropolitano passa a se expressar espacialmente no Brasil a partir da década de 1960, em virtude da complexidade urbano-industrial que caracteriza o país com mais intensidade a 
partir daquele período. No entanto, juridicamente, a possibilidade de estabelecimento de regiões metropolitanas no território brasileiro passa a existir, oficialmente, após introdução de emenda ao artigo 157 da Constituição Federal Brasileira de 1967 (BRASIL, 1967), que estabelecia: "que a União, mediante lei complementar, poderia instituir regiões metropolitanas no país"; e que estas seriam constituídas por municípios que, independentemente de sua vinculação administrativa fizessem parte de uma mesma comunidade socioeconômica.

A partir da Constituição de 1967 e das ações engendradas pelo Ministério do Planejamento, alguns estudos foram realizados a fim de definir e delimitar as regiões metropolitanas brasileiras e suas respectivas bases jurídico-administrativas. Conforme Guimarães (2004), entre esses estudos devem ser destacados os realizados pelo Instituto Brasileiro de Geografia e Estatística (IBGE), que buscaram estabelecer alguns critérios fundamentais para a definição das regiões metropolitanas. São eles:

- a magnitude da população aglomerada;

- a extensão da área urbanizada sobre o território de mais de um município;

- a integração econômica e social do conjunto;

- e a complexidade das funções desempenhadas.

Apesar da Emenda Constitucional de 1967, somente a partir de 1973 é que houve, de fato, a edição da legislação que viria instituir as regiões metropolitanas brasileiras, com a Lei Complementar $n^{\circ}$. 14, de 1973. É importante salientar que tais iniciativas emergem no contexto do regime militar brasileiro, sobrepondo-se a iniciativas locais/regionais que existiram anteriormente, construídas nas escalas municipal e estadual; tais expedientes buscaram, portanto, antes das regulações constitucionais, encontrar soluções para os problemas urbanos crescentes nas grandes cidades brasileiras - especialmente São Paulo e Rio de Janeiro - sobretudo a partir de 1960. Neste sentido,

A institucionalização da metrópole no Brasil se constitui em um dos marcos de um projeto geopolítico de integração do território nacional e do desenvolvimento industrial com base em uma sociedade dominantemente urbana. Partia-se do pressuposto de que uma rede urbana funcionalmente interdependente e hierarquizada devia assegurar a consecução de metas comuns e o equilíbrio do sistema (DAVIDOVICH, 2003, p. 57). 
Sendo assim, a partir de 1973 foram instituídas oito regiões metropolitanas no Brasil: São Paulo, Belo Horizonte, Porto Alegre, Curitiba, Salvador, Recife, Fortaleza e Belém; posteriormente, com a Lei 20/75 de 1974, foi instituída a região metropolitana do Rio de Janeiro (FIGURA 2).

A escolha dessas nove regiões metropolitanas obedeceu mais aos objetivos de se desenvolver um sistema urbano no país de acordo com as necessidades da estratégia de desenvolvimento econômico assumido pelo regime militar, do que priorizar, de fato, as cidades com reais atributos de áreas metropolitanas. Corrobora esta observação o fato de que cidades como Santos, Goiânia e Campinas ficaram de fora daquela organização espacial metropolitana, mas poderiam perfeitamente enquadrar-se em alguns dos critérios definidos pelo IBGE para instituição de uma área metropolitana (GUIMARÃES, 2004).

FIGURA 2 - Brasil: regiões metropolitanas (1973/74)

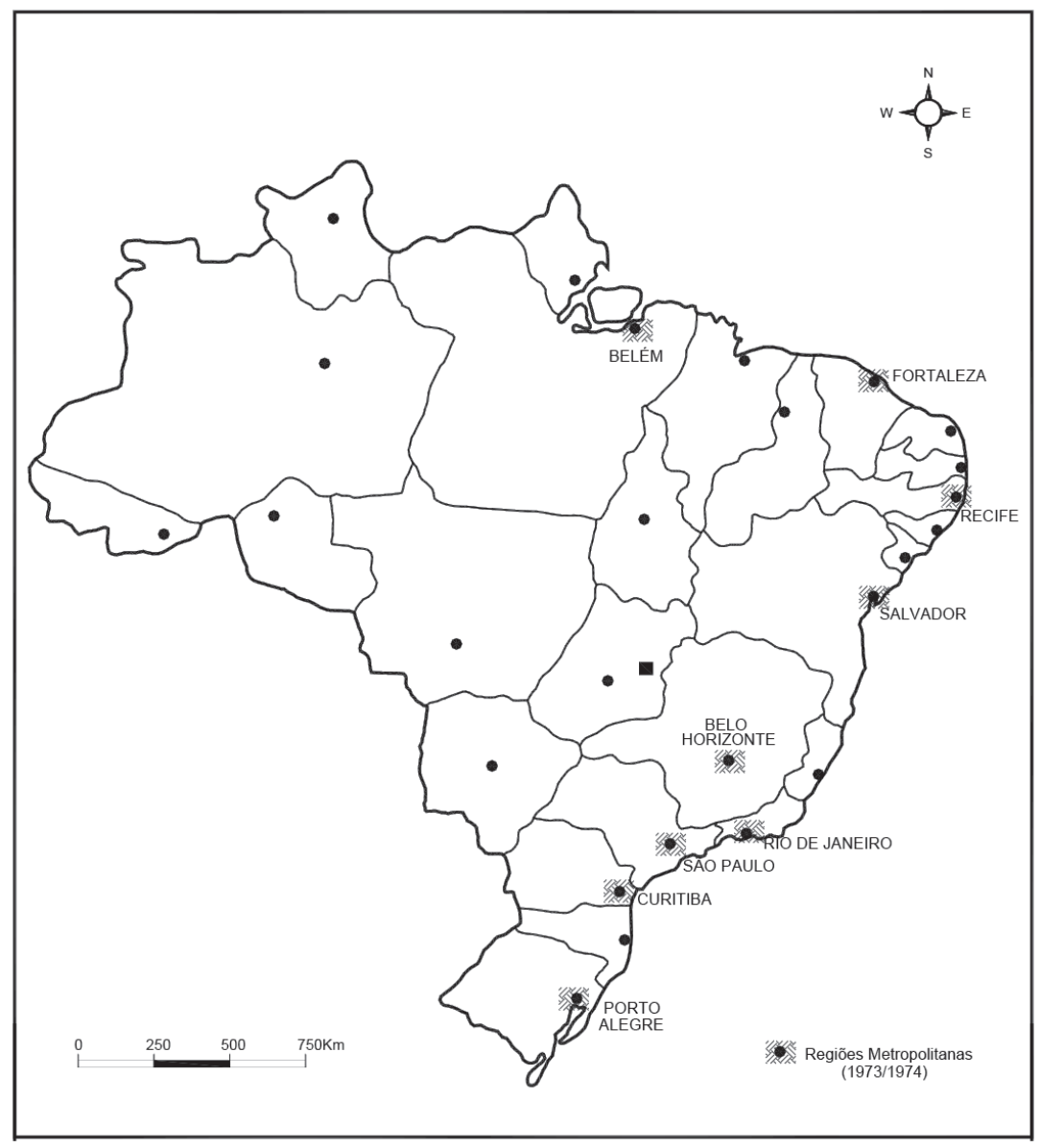

Fonte: IBGE, 1990.

Notas: Elaboração de Gilmar Alves Trindade, 2011. Digitalização de CADS Cópias Ltda. 


\section{As tranSFORMaÇÕes PROMOVIDAS PELA CONSTITUIÇÃo Federal BRASILEIRA DE 1988: AS NOVAS REGIÕES METROPOLITANAS BRASILEIRAS}

A partir da promulgação da Constituição Federal Brasileira de 1988, a normatização acerca da instituição de regiões metropolitanas no território brasileiro sofreu sensíveis modificações, privilegiando-se, então, a escala estadual de gestão, conforme rege o inciso $3^{\circ}$. do seu artigo 25:

$\int 3^{\circ}$ Os estados poderão, mediante lei complementar, instituir regiões metropolitanas, aglomerações urbanas e microrregiões, constituídas por agrupamentos de municípios limítrofes, para integrar a organização, o planejamento e a execução de funções públicas de interesse comum (OLIVEIRA, 2002, p. 41).

Após 1990 são instituídas novas regiões metropolitanas no âmbito da organização espacial brasileira, agora, já através de leis estaduais. Alguns autores consideram muitas dessas novas regiões metropolitanas como inseridas no contexto de uma metropolização emergente, enquanto as demais metrópoles, instituídas anteriormente, integrariam o contexto de uma metropolização completa ou plena. De qualquer forma,

\footnotetext{
Mudanças importantes se operam na espacialidade da concentração urbana, com a formação de mega-aglomerados: trata-se de extensas manchas urbanas que não correspondem mais à forma - cidade tradicional, nem à forma - metrópole conhecida. Revestem-se de uma conotação regional, que leva a identificá-las como cidades-região (DAVIDOVICH, 2003, p. 58).
}

Cidades que não podem ser entendidas sem a consideração da interdependência que cada vez mais intensamente, passa a existir entre elas e seus espaços imediatamente derivados, isto é, a cidade-sede da região metropolitana e todas aquelas que orbitam em torno de sua influência direta, formando uma só unidade de análise. O centro metropolitano é mais que uma simples cidade, pois a gama de funções urbanas que ele detém o coloca em outro patamar de análise. Neste sentido,

Os termos cidade e metrópole, para os diferentes autores, são admitidos como momentos diferenciados de um processo que comporta a passagem de um para o outro [...] a cidade se metropoliza na medida em que amplia sua extensão física (ALFREDO, 2003, p. 45). 


\section{A partir dessa perspectiva se pode imaginar que}

Nesse processo de metropolização do espaço é que reside a nova rede de relações que permite reconstituir, do ponto de vista teórico, a unidade entre cidade e região (LENCIONI, 2003, p. 35).

De acordo com Silva et al. (1987, p. 33),

O espaço organizado por um determinado sistema de cidades, sobretudo a partir do seu centro mais importante, é a região, ou seja, um espaço funcionalmente integrado e delimitado pelo conjunto de suas relações.

Estas podem ter maior ou menor intensidade, dependendo da qualidade e da quantidade dos bens e serviços disponíveis na metrópole e da existência de infraestrutura que facilite a articulação e a fluidez entre as cidades da região. Na realidade,

A metrópole regional oferece a gama completa de bens e serviços que naquele tipo particular de sociedade é consumida pela população em razão de seu nível de renda e padrão cultural. A metrópole oferece um conjunto de bens e serviços que somente ela está apta a oferecer (CORRÊA, 1989, p. 23).

Evidentemente que ocorre uma relação assimétrica entre a metrópole e as demais cidades que integram a região metropolitana, uma vez que

A metrópole regional aparece como sendo relativamente rica, pois acaba sendo o único centro que apresenta uma complexa gama de bens e serviços, distanciando-se muito, neste aspecto, das demais (CORRÊA, 1989, p. 35).

No interior da região metropolitana,

Os espaços centrais da metrópole atuam como focos de subordinação territorial, como os espaços a partir dos quais se inicia o processo de acumulação metropolitana, porque sua alta acessibilidade, sua concentração de atividades altamente produtivas, de gestão ou de decisão lhe dão um alto valor de troca que anula absolutamente seu valor de uso (ROBIRA, 2005, p. 16). 
Com isso se cria uma dinâmica espacial cuja tendência é sempre se ampliar, no sentido de consolidar espaços a serem usados seletivamente por determinadas atividades e demandas metropolitanas relacionadas ao movimento de acumulação capitalista, em detrimento de usos e demandas sociais. Ou seja,

A construção da metrópole torna visíveis os usos e as formas de apropriação do espaço, que se associa diretamente às formas de propriedade privada do solo urbano, apontando para uma hierarquização socioespacial (CARLOS, 2001, p. 33).

Além disso, conforme observou Santos (1994), a socialização capitalista favorecida pelo poder público nessas áreas metropolitanas é acompanhada por uma expansão periférica, que inclui a criação de distritos industriais, e pela concentração geográfica dos serviços de interesse coletivo em determinados lugares do espaço metropolitano.

As regiões metropolitanas aglomeram população, capacidade produtiva, serviços modernos e infraestrutura econômica, ocupando antigas áreas rurais e transformando-as em espaços eminentemente urbanos. Nos dias de hoje,

O processo de metropolização do espaço não reconhece as fronteiras administrativas, ele transcende a elas e produz um aglomerado metropolitano com alta densidade de área construída apresentando áreas bastante conurbadas e interrompidas, aqui e acolá (LENCIONI, 2003, p. 36).

Contudo, hoje, embora o espaço tenda à homogeneização, apresenta disparidades e diferenças. Essas diferenças são como fragmentos que testemunham resistência ao processo de homogeneização ou revelam que tal processo os ignorou. E isso independe da escala de análise, a intraurbana ou regional, pois o processo de homogeneização e fragmentação pode ser apreendido em diferentes escalas, conforme aponta Lencioni (2003). O que dizer das carroças puxadas a cavalo, coexistindo com a velocidade dos automóveis e com a aceleração contemporânea em pleno centro metropolitano de Aracaju, no ano de 2009 (FIGURA 3)? Ora,

Essas diferenças se constituem como fragmentos espaciais que testemunham ritmos diferentes de desenvolvimento do capital, de organização da vida social e da dinâmica da natureza. Por isso mesmo é que esses fragmentos são tão reveladores, pois aí vamos encontrar a possibilidade de capturar as diferentes temporalidades presentes nos lugares (LENCIONI, 2003, p. 41-42). 
FIGURA 3 - Vestígios de tempos lentos em plena fluidez do Centro de Aracaju, Sergipe

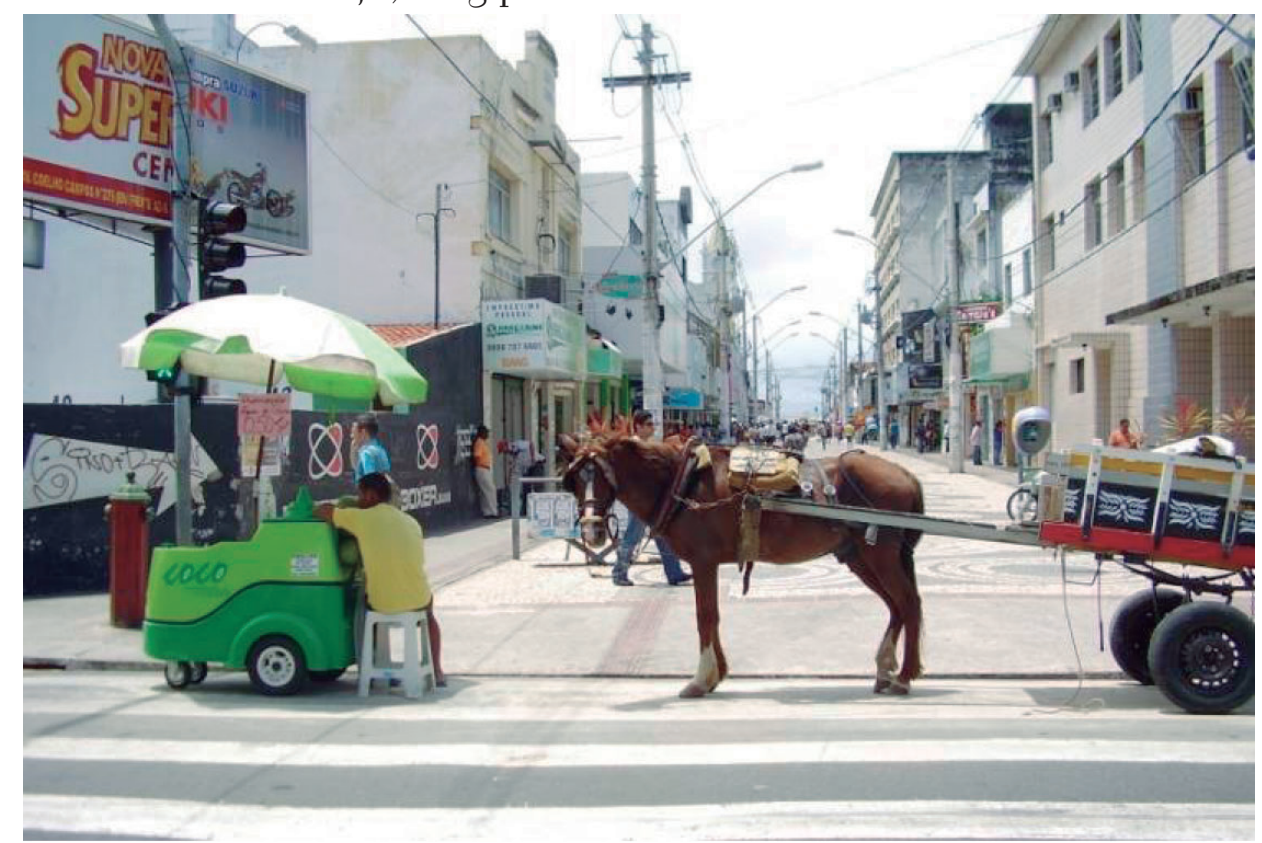

Fonte: Gilmar Alves Trindade e Diana Carvalho, 2009.

Tanto em espaços metropolitanos da região concentrada (SANTOS; SILVEIRA, 2001), quanto em espaços metropolitanos do Nordeste brasileiro, vamos encontrar esses fragmentos "do passado", esses vestígios de "tempos lentos" em meio à aceleração contemporânea, aspectos da vida rural em pleno movimento da vida metropolitana.

De acordo com Santos (1994), as atuais regiões metropolitanas têm, em comum, dois elementos essenciais: são formadas por mais de um município, com o município núcleo - que lhes dá o nome - representando uma área construída bem maior que os demais; e são alvos de programas especiais fomentados por organismos regionais especialmente criados com a utilização de normas comuns e de recursos geralmente destinados pelo governo federal.

Segundo Davidovich (2003), há diferentes formas de regiões metropolitanas: as de iniciativa federal, instituídas no regime militar, apresentam mais de um milhão de habitantes, sobressaindo as de São Paulo e Rio de Janeiro, com cerca de 18 e 11 milhões de pessoas, respectivamente; as de iniciativa estadual criadas, sobretudo, a partir de 1994, conforme os termos da política urbana que a Constituição de 1988 delegou a governos de unidades da Federação, sendo que nem todas as metrópoles recentes 
alcançam um milhão ou mais de habitantes. Verifica-se, também, uma diversificação acentuada dos centros, que abrange não só capitais estaduais, como também espaços sub-regionais e cidades não capitais (FIGURA 4).

FIGURA 4 - Brasil: regiões metropolitanas (2011)

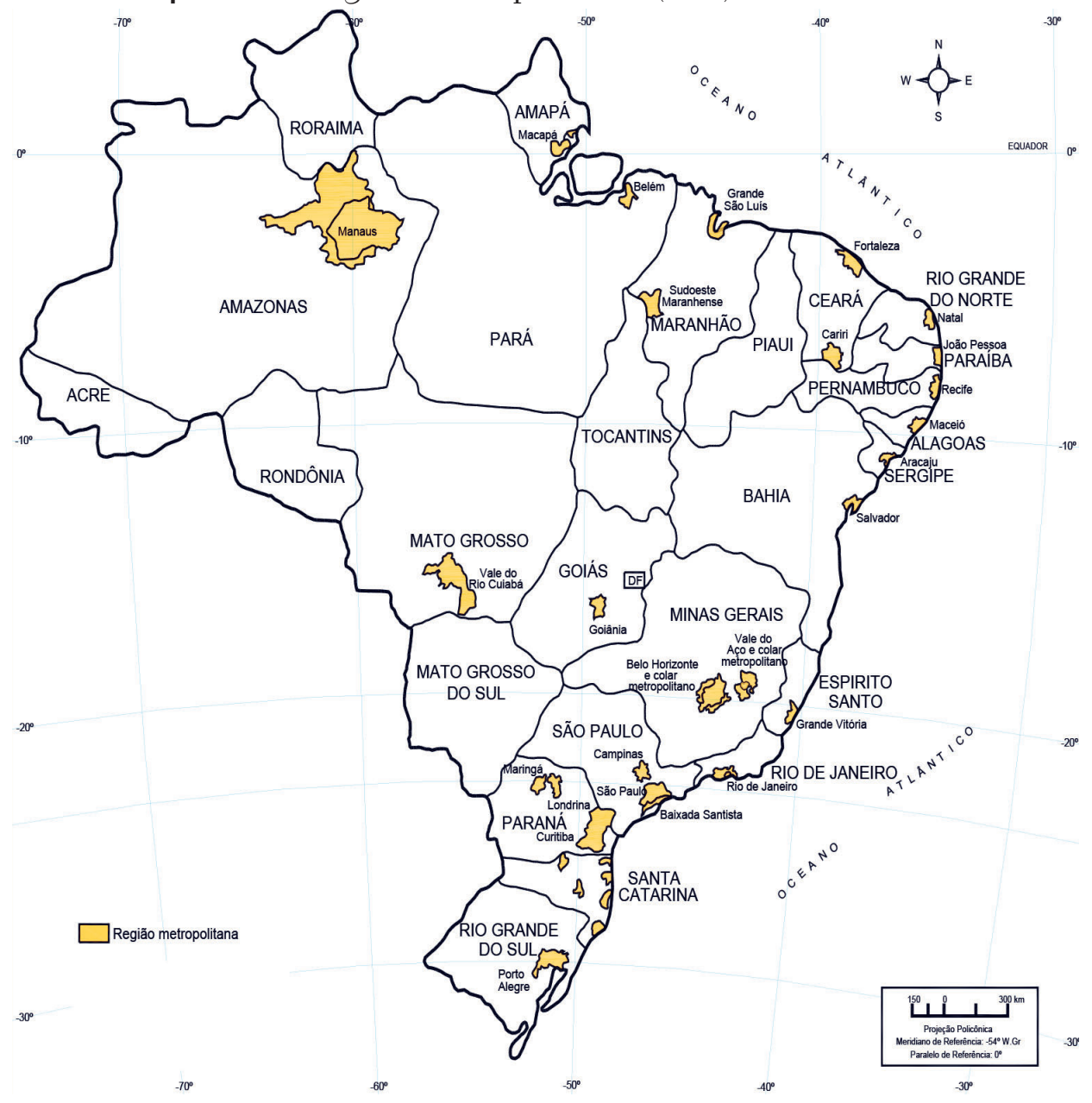

Fonte: IBGE, 2010.

Notas: Elaboração de Gilmar Alves Trindade, 2011. Digitalização de CADS Cópias Ltda.

Incluem-se no elenco dessas novas regiões metropolitanas, entre outras: Natal (RN), Maceió (AL), Vale do Itajaí (SC), Vitória (ES), Goiânia (GO), Florianópolis (SC), Vale do Aço (MG), Baixada Santista (SP), São Luís (MA), Campinas (SP), Londrina e Maringá (PR). No âmbito dessa recente metropolização do território brasileiro há alguns elementos que devem ser analisados e discutidos 
Entre as questões que podem ser levantadas, vale considerar até que ponto regiões metropolitanas recentes, as de iniciativa estadual, podem efetivamente ser identificadas nessa categoria, já que algumas delas não estariam se coadunando com critérios correntemente utilizados para essa caracterização, tais como a massa crítica de população da própria cidade central, a densidade demográfica e econômica dos municípios componentes, a representatividade das migrações pendulares e a acessibilidade, entre outros (DAVIDOVICH, 2003, p. 61).

Além disso, parte significativa dessas novas regiões metropolitanas não atinge um milhão de habitantes. São, na realidade, cidades de porte médio, que não têm comparação com o volume populacional das cidades centrais das regiões metropolitanas mais antigas. Ainda é preciso levar em conta

\begin{abstract}
Até que ponto as novas regiões metropolitanas também são indício de uma nova divisão do trabalho no território nacional, que envolve especialização e diversificação, competitividade e interdependência [...] uma divisão do trabalho que estaria correspondendo à reestruturação da acumulação em escala mundial (DAVIDOVICH, 2003, p. 62).
\end{abstract}

Oficialmente o IBGE considerou, recentemente, as atuais regiões metropolitanas brasileiras (QUADRO 1), no âmbito das quais é possível encontrar tanto as regiões metropolitanas mais antigas, instituídas na década de 1970, quanto novas regiões metropolitanas e mesmo o que é classificado como "colar metropolitano". Neste caso, trata-se de municípios localizados no entorno da região metropolitana (e não da metrópole), cujos fluxos mantidos com a metrópole são também bastante significativos, por meio de redes de articulação que os vinculam a ela em intensidade muitas vezes equivalente à dos municípios da região metropolitana.

Além das regiões metropolitanas oficiais temos também a definição de colares metropolitanos e de áreas de expansão metropolitana: dos entornos da R. M. de Belo Horizonte, do Vale do Aço, de Florianópolis, do Vale do Itajaí, do Norte-Nordeste Catarinense, da Foz do rio Itajaí, da R. M. Carbonífera, da R. M. de Tubarão, da R. M. de Chapecó e da R. M. do vale do rio Cuiabá. 
QUADRO 1 - As regiões metropolitanas brasileiras

\begin{tabular}{|c|c|c|}
\hline $\begin{array}{l}\text { Unidade da } \\
\text { federação }\end{array}$ & Região metropolitana/Núcleo & $\begin{array}{l}\text { Número de } \\
\text { municípios }\end{array}$ \\
\hline Amapá & o1. R. M. de Macapá (Macapá) & $\mathrm{O} 2$ \\
\hline Amazonas & o2. R. M. de Manaus (Manaus) & ○8 \\
\hline \multirow{2}{*}{ Alagoas } & 03. R. M. de Maceió (Maceió) & 11 \\
\hline & O4. R. M. do Agreste (Arapiraca) & 20 \\
\hline \multirow{2}{*}{ Bahia } & 05. R. M.de Salvador (Salvador) & 13 \\
\hline & o6. R. M. de Feira de Santana (F. de Santana) & o6 \\
\hline \multirow{2}{*}{ Ceará } & o7. R. M. de Fortaleza (Fortaleza) & 15 \\
\hline & o8. R. M. do Cariri (Juazeiro do Norte - Crato - Barbalha) & og \\
\hline Espírito Santo & og. R. M. de Vitória (Vitória) & 07 \\
\hline Goiás & 10. R. M. de Goiânia (Goiânia) & 20 \\
\hline \multirow{2}{*}{ Maranhão } & 11. R. M. de São Luís (São Luís) & 05 \\
\hline & 12. R. M. do Sudoeste Maranhense (Imperatriz) & 08 \\
\hline Mato Grosso & 13. R. M. do Vale do Rio Cuiabá (Cuiabá) & $04^{* *}$ \\
\hline \multirow{2}{*}{ Minas Gerais } & 14. R. M. de Belo Horizonte (Belo Horizonte) & $34^{*}$ \\
\hline & 15. R. M. do Vale do Aço (Ipatinga) & $04^{*}$ \\
\hline Pará & 16. R. M. de Belém (Belém) & 06 \\
\hline \multirow{2}{*}{ Paraíba } & 17. R. M. de João Pessoa (João Pessoa) & 12 \\
\hline & 18. R. M. de Campina Grande (Campina Grande) & 23 \\
\hline \multirow{3}{*}{ Paraná } & 19. R. M. de Curitiba (Curitiba) & 26 \\
\hline & 2o. R. M. de Londrina (Londrina) & 11 \\
\hline & 21. R. M. de Maringá (Maringá) & 25 \\
\hline Pernambuco & 22. R. M. de Recife (Recife) & 14 \\
\hline Rio de Janeiro & 23. R. M. do Rio de Janeiro (Rio de Janeiro) & 19 \\
\hline $\begin{array}{l}\text { Rio Grande } \\
\text { do Norte }\end{array}$ & 24. R. M. de Natal (Natal) & 10 \\
\hline Rio G. do Sul & 25. R. M. de Porto Alegre (Porto Alegre) & 32 \\
\hline \multirow{7}{*}{$\begin{array}{l}\text { Santa } \\
\text { Catarina }\end{array}$} & 26. R. M. de Florianópolis (Florianópolis) & $09^{*}$ \\
\hline & 27. R. M. do Vale do Itajaí (Blumenau) & $05^{*}$ \\
\hline & 28. R. M. do Norte/Nordeste Catarinense (Joinvile) & $\mathrm{O} 2^{*}$ \\
\hline & 29. R. M. da Foz do Rio Itajaí (Itajaí) & $05^{*}$ \\
\hline & 30. R. M. Carbonífera (Criciúma) & $07^{*}$ \\
\hline & 31. R. M. de Tubarão (Tubarão) & $03^{*}$ \\
\hline & 32. R. M. de Chapecó (Chapecó) & $16^{*}$ \\
\hline \multirow{3}{*}{ São Paulo } & 33. R. M. de São Paulo (São Paulo) & 39 \\
\hline & 34. R. M. da Baixada Santista (Santos) & o9 \\
\hline & 35. R. M. de Campinas (Campinas) & 19 \\
\hline Sergipe & 36. R. M. de Aracaju (Aracaju) & $\mathrm{O}_{4}$ \\
\hline
\end{tabular}

Fonte: IBGE (2002, 2007, 2010).

Notas: * Não incluindo os municípios dos colares metropolitanos e das áreas de expansão metropolitana.

Elaboração de Gilmar Alves Trindade, 2011. 
Há, ainda, a instituição da Região Integrada de Desenvolvimento (RIDE), que são as regiões metropolitanas que se localizam em duas ou mais unidades da federação; criadas por legislação federal - ao contrário das regiões metropolitanas, hoje definidas por leis estaduais - que definem os municípios integrantes da RIDE (QUADRO 2).

QUADRO 2 - Regiões Integradas de Desenvolvimento (RIDE)

\begin{tabular}{|l|l|l|}
\hline $\begin{array}{l}\text { Unidades da } \\
\text { Federação }\end{array}$ & RIDE & Especificidades \\
\hline DF-GO-MG & $\begin{array}{l}\text { Distrito Federal } \\
\text { e Entorno }\end{array}$ & $\begin{array}{l}\text { Constituída por Brasília (DF) mais 22 municípios } \\
\text { de Goiás e Minas Gerais, entre eles: Cristalina, } \\
\text { Pirenópolis e Luziânia. Foi criada em } 1998 .\end{array}$ \\
\hline PE-BA & $\begin{array}{l}\text { Polo Petrolina- } \\
\text { Juazeiro }\end{array}$ & $\begin{array}{l}\text { Instituída em 20o1, é formada por 9 municípios } \\
\text { do vale do São Francisco, tendo como núcleos a } \\
\text { conurbação Petrolina-Juazeiro. }\end{array}$ \\
\hline PI-MA & Grande Teresina & $\begin{array}{l}\text { Instituída em 20o2, é composta por Teresina mais } \\
\text { 12 municípios do Piaú, e também por um mu- } \\
\text { nicípio do Maranhão, Timon, cuja sede é arti- } \\
\text { culada com Teresina por uma ponte sobre o rio } \\
\text { Parnaíba. }\end{array}$ \\
\hline
\end{tabular}

Fonte: BRASIL (2010).

Nota: Elaboração de Gilmar Alves Trindade, 2011.

Convém, ainda, lembrarmos da existência no território de aglomerações urbanas, que são espaços constituídos por duas ou mais cidades conurbadas ou em processo acelerado de conurbação; são espaços dinâmicos que exercem forte influência em seus entornos regionais, constituindo, efetivamente, uma unidade urbana com algumas características metropolitanas, porém, com um nível de complexidade menor que o das regiões metropolitanas. Podemos dar como exemplo o caso da aglomeração Itabuna-Ilhéus (TRINDADE, 2011).

\section{O CENTRO METROPOLITANO E A FUNÇÃo DE CENTRALIDADE}

A partir do estudo das regiões metropolitanas é possível realizar, geograficamente, uma análise mais apurada acerca do atual momento da organização socioespacial. Através das redes geográficas as cidades são articuladas ao espaço metropolitano mais imediato, integrando a região ao território nacional e a outros lugares e regiões do mundo. Sendo assim, "a 
ideia de espaço metropolizado e não-metropolizado, no nosso entender, possibilita amalgamar questões urbanas e regionais, que há muito vêm trilhando caminhos paralelos" (LENCIONI, 2003, p. 43) e inseri-las no âmbito dos fluxos mundiais que caracterizam o atual momento de desenvolvimento da sociedade.

No interior do espaço metropolitano, especificamente,

Os fluxos de circulação mais concentrados correspondem às artérias mais comerciais, o que se relaciona com o fenômeno que faz do centro das cidades um lugar de reunião para quase todas as categorias da sociedade urbana (SANTOS, 1981, p. 209).

No bojo dessas relações se faz necessário considerar a articulação entre produção, circulação, distribuição e consumo, fatores fundamentais para manter o dinamismo e a densidade econômica das regiões metropolitanas, que precisam ser fluidas. É interessante observar que

A partir da disseminação do uso do automóvel, o centro da cidade foi colocado em questão pelos habitantes da metrópole $[. .$.$] , o centro se pulverizou, provocando uma reorga-$ nização da cidade, com o surgimento de centros especializados - de compras, de decisão, financeiro [...], além disso, a rede de transportes de massa permitiu que o periférico se aproximasse do que é central em questão de minutos (PINTAUDI, 1999, p. 156).

Todavia, não é demais lembrar que, nos espaços metropolitanos, a pulverização das áreas centrais tradicionais se caracteriza pela emergência de subcentros e de novas centralidades, como aquelas relacionadas aos lugares das metrópoles onde há a instalação de shopping centers. Quanto à questão das centralidades urbanas pode-se considerar que

A centralidade de um núcleo refere-se ao seu grau de importância a partir de suas funções centrais: maior o número delas, maior a sua região de influência, maior a população externa atendida pela localidade central, e maior a sua centralidade (CORRÊA, 1989, p. 21).

Os conceitos de centralidade e de cotidianidade são importantes instrumentos para o desenvolvimento de um pensamento geográfico crítico 
sobre o comércio urbano (PINTAUDI, 1999), as relações socioespaciais e a dinâmica das próprias regiões metropolitanas. Para isso faz-se necessário conhecer o processo de constituição do espaço metropolitano em estudo, sua evolução têmporo-espacial e os fatores sociais, políticos e econômicos responsáveis pela emergência das novas centralidades metropolitanas. Mas é preciso ter cuidado, pois

O conceito de centralidade é também algo relativo, somente existe centralidade urbana ou metropolitana se existe um território ao qual se subordinar social, política e economicamente. A centralidade somente é possível se existe um espaço subordinado, uma periferia, de características totalmente opostas (ROBIRA, 2005, p. 16).

São exatamente essas assimetrias que contribuirão para consolidar as funções metropolitanas da cidade-núcleo da região. Apesar de considerar as relações informacionais que caracterizam este momento, muitas vezes marcadas pelo predomínio de fluxos imateriais, é preciso lembrar que tais fluxos circulam através de redes-suporte (BENAKOUCHE, 1995; TOLEDO JÚNIOR, 2003), e que essas redes são muito mais densas nos espaços metropolitanos que nos demais lugares do território. Além disso, para uma grande parte da população que reside ou circula nos espaços metropolitanos, a velocidade dos fluxos de transportes e de comunicação ainda é bastante lenta, contrastando, assim, com a fluidez que a paisagem metropolitana faz supor que existe efetivamente para todos. 


\section{REFERÊNCIAS}

ALFREDO, A. Cidade e metrópole: uma identidade contraditória no processo da urbanização contemporânea. In: CARLOS, A. F. A. et al. (org.). Dilemas urbanos: novas abordagens sobre a cidade. São Paulo: Contexto, 2003.

BENAKOUCHE, T. Redes de comunicação eletrônica e desigualdades regionais. In: GONÇALVES, M. F. (org.). O novo Brasil urbano: impasses, dilemas e perspectivas. Porto Alegre: Mercado Aberto, 1995.

BRASIL. Constituição da República Federativa do Brasil. Brasília, DF: [s.l.], 1967.

. Governo Federal. Regiões Integradas de Desenvolvimento Econômico (RIDE) (2010). Brasília, DF, 2010. Disponível em: $<\underline{\text { http://www.integracao.gov.br/programasregionais/ }}$ rides/index.asp>. Acesso em: 29 dez. 2011.

CARLOS, A. F. A. O lugar no/do mundo. São Paulo: Hucitec, 1996.

Espaço-tempo na metrópole. São Paulo: Contexto, 2001.

CLARK, D. Introdução à Geografia Urbana. São Paulo: Difel, 1985.

CORRÊA, R. L. A rede urbana. São Paulo: Ática, 1989.

DAVIDOVICH, F. Metrópole e contemporaneidade: algumas pontuações. In: CARLOS, A. F. A. et al. (org.). Dilemas urbanos: novas abordagens sobre a cidade. São Paulo: Contexto, 2003.

GUIMARÃES, N. A. Regiões metropolitanas: aspectos jurídicos. Rio de Janeiro: EdUERJ, 2004. Disponível em: $<$ http// www.fcaa.com.br/site/artigo/regiaometropolitana.pdf>. Acesso em: 18 jul. 2011. 
INSTITUTO BRASILEIRO DE GEOGRAFIA E ESTATÍSTICA (IBGE). Atlas Geográfico Escolar. Rio de Janeiro: IBGE, 2002.

. Regiões metropolitanas brasileiras. 2007. Brasília, DF, 2008. Disponível em: $<h t t p / w w w . i b g e . g o v . b r>$. Acesso em: 23 out. 2011.

LENCIONI, S. Uma nova determinação do urbano: o desenvolvimento do processo de metropolização do espaço. In: CARLOS, A. F. A. et al. (org.). Dilemas urbanos: novas abordagens sobre a cidade. São Paulo: Contexto, 2003.

OLIVEIRA, C. B. de (org.). Constituição da República Federativa do Brasil. Rio de Janeiro: Roma Victor, 2002.

PINACOTECA de São Paulo. Panorama de São Paulo: final do século XX. São Paulo: Imprensa Oficial, 2004.

PINTAUDI, S. M. A cidade e as formas do comércio. In:

CARLOS, A. F. A. (org.). Novos caminhos da Geografia. São Paulo: Contexto, 1999.

ROBIRA, R. T. Áreas metropolitanas: espaços colonizados. In: CARLOS, A. F. A. et al. (org.). Urbanização e mundialização: estudos sobre a metrópole. São Paulo: Contexto, 2005.

SANTOS, M. Manual de Geografia Urbana. São Paulo: Hucitec, 1981.

A urbanização brasileira. São Paulo: Hucitec, 1994.

A natureza do espaço: técnica e tempo, razão e emoção. 3. ed. São Paulo: Hucitec, 1999.

SANTOS, M.; SILVEIRA, M. L. O Brasil: território e sociedade no início do século XXI. Rio de Janeiro: Record, 2001. 471p. 
SILVA, S. B. M.; SILVA, B. C. N.; LEÃO, S. O. O subsistema urbano-regional de Ilhéus e Itabuna. Recife: SUDENE, 1987.

TOLEDO JÚNIOR, R. Telecomunicações e uso do território brasileiro. In: SOUZA, M. A. de. Território brasileiro: usos e abusos. Campinas, SP: Edições Territorial, 2003.

TRINDADE, G. A. Aglomeração Itabuna-Ilhéus: cidade, região e rede urbana. 2011. 361 f. Tese (Doutorado em Geografia) - Núcleo de Pós-graduação em Geografia, Universidade Federal de Sergipe, São Cristóvão, 2011. Disponível em: <http://www.biblioteca.uesc.br/ biblioteca/bdtd/732820572T.pdf >. Acesso em: 12 dez. 2011. 


\section{RELATO DE UMA \\ PESQUISA DE CAMPO \\ QUALITATIVA SEGUNDO \\ OS PROPÓSITOS DA \\ GEOGRAFIA HUMANISTA}

\section{Rita Jaqueline Nogueira Chiapetti}

\section{INTRODUÇÃO}

Este texto tem como objetivo principal relatar uma experiência em uma pesquisa de campo do tipo qualitativa, com abordagem em Geografia Humanista. Portanto, esclarecemos que se refere ao relato de uma experiência em uma pesquisa de campo e não à apresentação/discussão de dados/informações colhidos em campo.

A pesquisa de campo foi feita no município de Itacaré, sul do estado da Bahia, com o objetivo de colher informações diretamente de pessoas que têm alguma relação com o principal elemento hídrico da região, o rio das Contas, já que sua presença sempre foi de fundamental importância para a existência da vida humana no lugar.

A linha de pensamento da Geografia Humanista é muito apropriada para este tipo de pesquisa, pois se caracteriza, principalmente, pela valorização das relações de afetividade desenvolvidas pelos indivíduos atinentes ao seu ambiente, ou seja, na subjetividade humana é que se encontram as interpretações para suas atitudes perante o mundo (MELLO, 1990; HOLZER, 1993; 1997).

Para se fazer Geografia Humanista, no entanto, é preciso uma escolha consciente, com paixão, com encantamento, pois, conforme Gratão (2002, p. 24),

a Geografia Humanística não é só um '(per)curso alternativo' [...] ela tem outras buscas... outros sentidos... É como seguir um novo caminho... outros olhares... outros significados... outras paragens... outras travessias... É uma outra viagem (grifo do autor). 
Dentro dessa perspectiva, nessa pesquisa/viagem geográfica para compreendermos o que é o rio das Contas para as pessoas de Itacaré, buscamos os olhares de sujeitos de diversas idades e profissões que experienciam, vivenciam o rio das Contas, percebendo o significado do rio para elas, registrando suas emoções, seus sentimentos...

Vivenciar é mais do que viver, é viver com sentimento, ter relação com... se envolver, adquirir experiência, experienciar. Foi com esse desejo que fizemos nossa pesquisa de campo nas margens do rio das Contas no município de Itacaré, pois esse caminho fluvial não é somente um mero acidente geográfico, que podemos representar no mapa, ou estudar a geomorfologia fluvial ou, ainda, que temos a possibilidade de explorar como um recurso econômico. Envolvemo-nos com esse rio porque ele é muito mais do que isso, já que em todo o seu percurso carrega, simbolicamente, a existência humana com a sua infinidade de desejos, intenções, ações... (CHIAPETTI, 2010)

Os locais escolhidos para fazer a pesquisa foram a cidade de Itacaré, o distrito de Taboquinhas (localizado na margem direita do rio, a 25 quilômetros da cidade de Itacaré) e, ainda, um restaurante, duas fazendas cacaueiras e quatro Comunidades Quilombolas Rurais, todos localizados nas margens ao longo do rio, entre a cidade e o distrito (FIGURA 1).

A partir da influência humanista, o pensar geográfico sobre um determinado lugar passa a considerar os aspectos da percepção de quem ali habita. Para tanto é necessário conhecer as relações que essas pessoas têm com o seu lugar, considerando seus significados e representações, colocando questões em torno do mundo percebido, vivido e experienciado.

O lugar, mais que o espaço, relaciona-se à existência real e à experiência vivida e, por ser repleto de significados, é visto como algo que transcende sua materialidade, mas é único, concreto e revela uma paisagem. Para Tuan (1983), lugar é um produto da experiência humana e das aspirações pessoais, sendo uma realidade que deve ser compreendida na perspectiva dos que lhe dão significado, mobilizando seu intelecto e suas emoções.

O Contas é um rio de características peculiares, pois nasce num "oásis" dentro da região semiárida baiana (serra da Tromba, oeste da Chapada Diamantina), dentro do município de Piatã e, depois de fluir perenemente por cerca de $400 \mathrm{~km}$ pelo sertão baiano na direção leste, penetra na área coberta pela Mata Atlântica (por mais 100 km, aproximadamente), quando suas águas se agitam em corredeiras e cachoeiras, seu leito fica muito estreito dentro de um cânion (cerca de $4 \mathrm{~m}$ de largura), para depois voltar a descer calmamente até o encontro com o mar na cidade de Itacaré, proporcionando imagens maravilhosas à população local e aos turistas. 


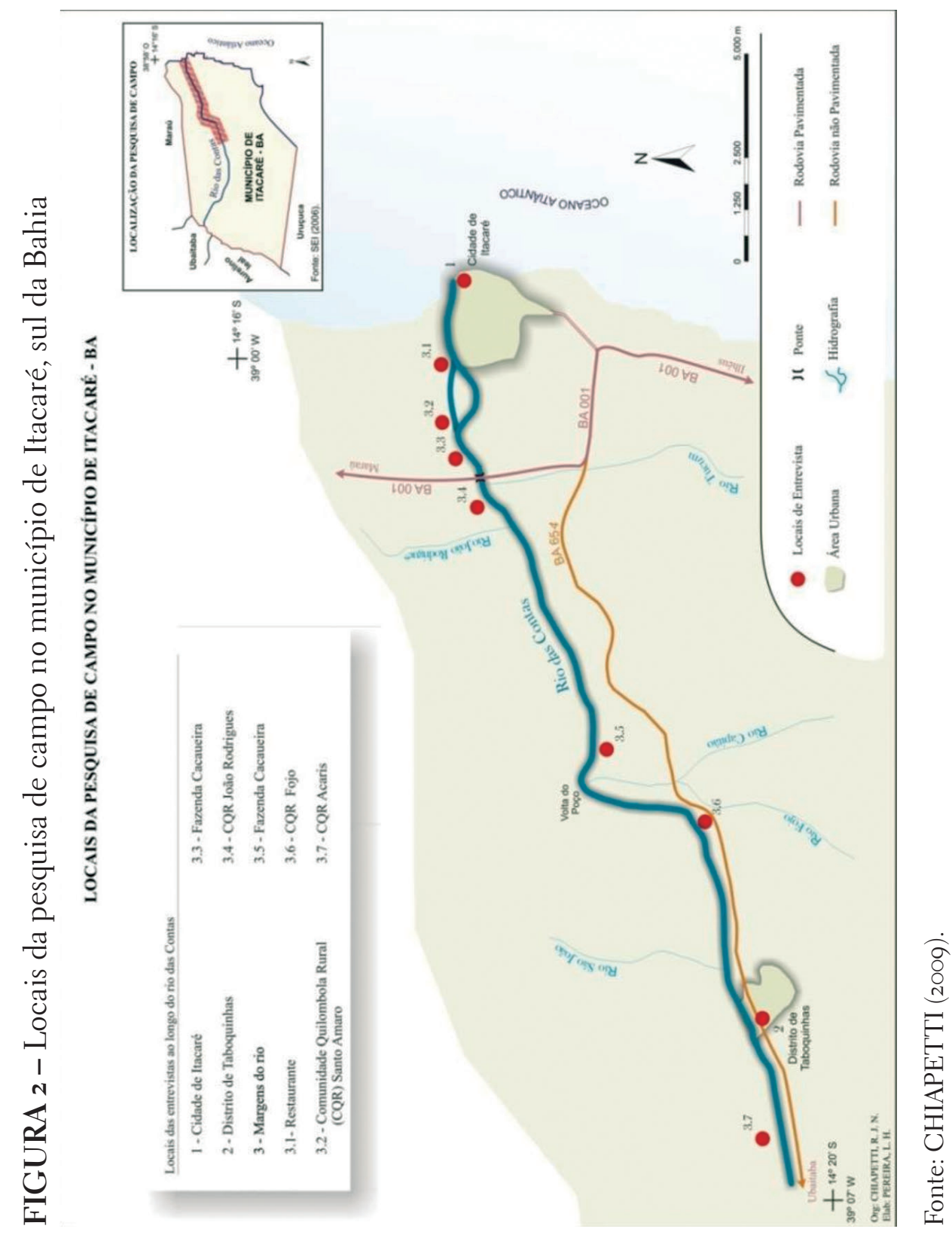

Segundo Chiapetti, Rita e Chiapetti, Jorge (2011, p. 88), "Como todo rio, o rio das Contas tem diversas imagens, mas a certeza da sua última imagem é chegar ao seu destino... o mar do Oceano Atlântico!" (FIGURA 2).

O encantamento com a presença do trecho do rio das Contas dentro do município de Itacaré em área de Mata Atlântica foi, então, um dos 
motivos para sua escolha como lugar de pesquisa. Mas, certamente, a contribuição do rio para a ocupação humana da sua bacia hidrográfica e para o turismo regional, além da beleza das suas paisagens foram também motivos importantes quanto à opção por tal lugar.

Partindo do problema de pesquisa, ou seja, como as pessoas de Itacaré percebem o rio das Contas, definimos o objeto e o objetivo geral. Assim, definimos como objeto da nossa pesquisa a percepção do rio das Contas pelas pessoas que moram próximas a ele. E, como principal objetivo, compreender como as pessoas de Itacaré percebem o rio das Contas, pois sendo um elemento obrigatório da paisagem itacareense, sua presença está profundamente enraizada na percepção dos moradores. De acordo com essa perspectiva, podemos afirmar que a nossa pesquisa pode ser considerada peculiar quanto ao modo diferente de olhar e perceber a realidade do rio das Contas, a partir da experiência e apropriação do conhecimento dos moradores de Itacaré.

FIGURA 2 - O rio das Contas no encontro com o mar em Itacaré, sul da Bahia

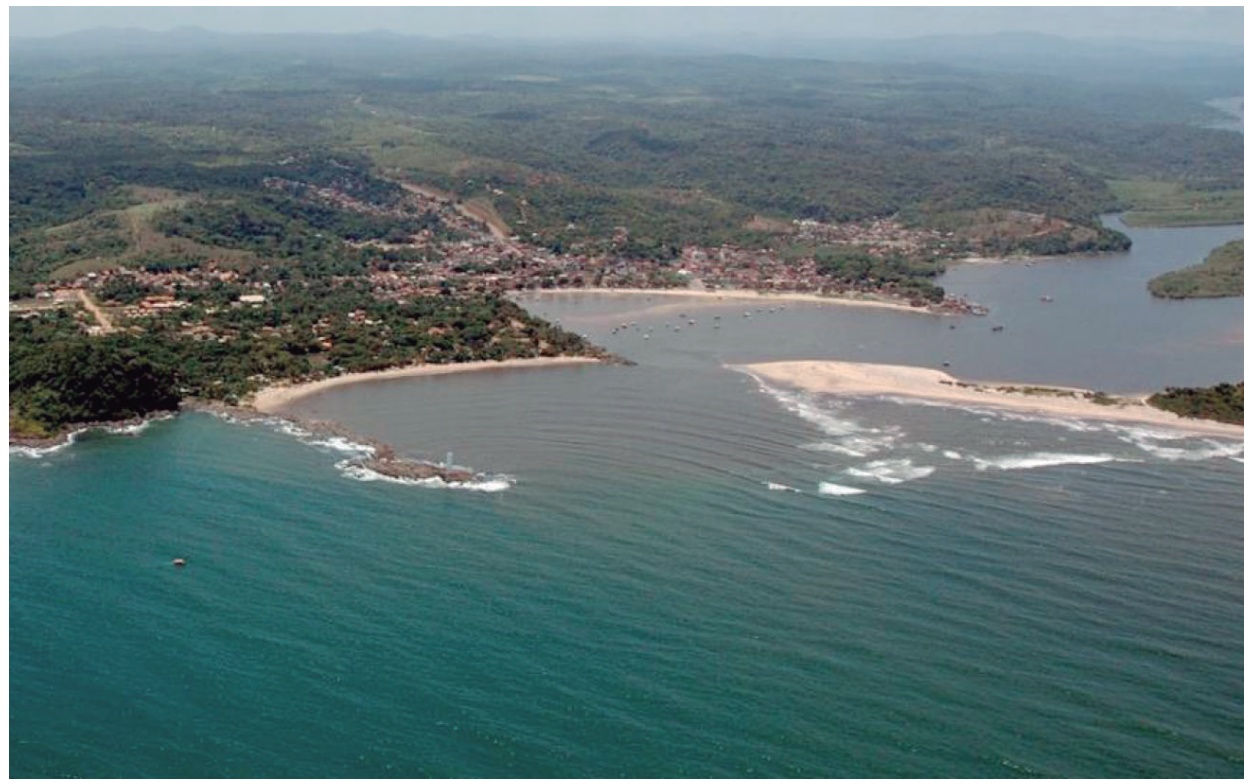

Fonte: José Nazal Pacheco Soub. 


\section{TRILHANDO O CAMINHO DA PESQUISA DE CAMPO NAS ÁGUAS DO RIO Das Contas}

Para trilhar o caminho da pesquisa de campo, voltamo-nos ao objeto e aos objetivos da nossa pesquisa definidos anteriormente, pois é através deles que sabemos onde queremos chegar. Portanto, nossa pesquisa se pautou em uma abordagem qualitativa, visto que queríamos obter "algo" a partir de informações de pessoas de Itacaré.

De acordo com Minayo (1994), a pesquisa de campo é o recorte que o pesquisador faz em termos de espaço, representando uma realidade empírica a ser estudada a partir das concepções teóricas que fundamentam o objeto da investigação.

Segundo Suertegaray (2002), o trabalho de campo é um instrumento de análise geográfica que permite o reconhecimento do objeto e que, fazendo parte de um método de investigação, permite a inserção do pesquisador no movimento da sociedade como um todo.

Para Duarte (2002), uma pesquisa de campo é um relato de longa viagem empreendida por um pesquisador, cujo olhar se dirige a lugares já conhecidos por muitos, mas sempre com um modo diferente de olhar e pensar determinada realidade, a partir de uma experiência e de uma apropriação do conhecimento que são bastante pessoais.

Para Chiapetti (2010, p. 145), "Pesquisar é buscar e, portanto, pesquisar em campo é buscar respostas (em algum local) para responder às questões da pesquisa".

Sobre pesquisas qualitativas, Bogdan e BiKlen (1994) escrevem que, ao valorizarem os aspectos descritivos e as percepções pessoais, procuram compreender os sujeitos envolvidos e, por seu intermédio, compreender, também, o contexto em que vivem. Elas lidam com valores, crenças, hábitos, atitudes, representações, significados e opiniões expressos pela linguagem comum e na vida cotidiana das pessoas. Procuram, dessa maneira, trabalhar com dados qualitativos que envolvem a descrição pormenorizada das pessoas, de locais e dos fatos envolvidos. Ao mesmo tempo, a abordagem qualitativa de pesquisa é empregada para aprofundar e compreender a complexidade dos fenômenos.

De acordo com Teixeira (2006, p. 137):

$\mathrm{Na}$ pesquisa qualitativa o pesquisador procura reduzir a distância entre a teoria e os dados, entre o contexto e a ação, usando a lógica da análise fenomenológica, isto é, da 
compreensão dos fenômenos pela sua descrição e interpretação. As experiências pessoais do pesquisador são elementos importantes na análise e compreensão dos fenômenos estudados.

Como nossa pesquisa de campo é qualitativa, optamos por ouvir as pessoas através do método da história oral, com a técnica do depoimento e, também, observar as paisagens e situações, registrando-as em fotografias. A seguir discorreremos sobre a abordagem teórica que escolhemos, como principal estratégia para a pesquisa de campo.

\section{A ORALIDADE COMO ESTRATÉGIA PARA OBTER AS INFORMAÇÕES NA PESQUISA DE CAMPO}

São muitos os métodos e as técnicas de coleta de dados em uma abordagem qualitativa de pesquisa de campo na Geografia Humanista e, entre eles, a história oral ocupa lugar de destaque. A importância da história oral está na subjetividade do sujeito que fornece, às fontes orais, elementos que nenhuma outra fonte seria capaz de dar, pode mostrar significados, simbolismos e os fatos cedem passagem à imaginação. A história oral tornase valiosa, ainda, por se colocar justamente no ponto em que se cruzam a vida individual desses sujeitos e o seu contexto social. A riqueza da pesquisa com esta metodologia está na ênfase dada e na importância atribuída aos sujeitos, construtores de seu destino, entre possibilidades e limites.

Para Whyte (1977, p. 71), a

Oral history is a method whereby oral evidence is taken from people who have usually directly experienced the events they talk about or who are relating accounts that have been personally handed down to them.

A mesma autora ainda escreve que a evidência oral é muito importante para o estudo da percepção ambiental porque revela não somente os fatos da experiência e comportamento ambiental, mas, também, os sentimentos e significados para as pessoas que estão associadas a eles.

\footnotetext{
História oral é um método pelo qual a evidência é falada pelas pessoas que tiveram experiência direta com os eventos/acontecimentos, ou que estejam relacionados com relatos que foram pessoalmente transmitidos a elas (tradução livre da autora).
} 
Nos relatos dos próprios sujeitos sobre os eventos, acontecimentos, pessoas e lugares, eles revelam suas percepções, atitudes e valores, bem como expressam o espírito e o sentimento de realmente terem estado presentes.

Desse modo, pensar a história oral como a possibilidade de entender "o vivido" de cada sujeito, as sensações, os sentimentos, as percepções, os valores, as crenças, os referenciais simbólicos e as visões de mundo fazem dela um método válido em pesquisas de percepção do meio ambiente. $\mathrm{O}$ importante, neste caso, é que seja enfocado diretamente o tema de interesse do pesquisador.

Segundo Meihy (2000, p. 29):

A história oral é um conjunto de procedimentos que se inicia com a elaboração de um projeto e que continua com a definição de um grupo de pessoas (ou colônia) a ser entrevistado, com o planejamento da condução das gravações, com a transcrição para o uso, arquivamento e, sempre que possível, com a publicação dos resultados que devem, em primeiro lugar, voltar ao grupo que gerou as entrevistas.

Para Alberti (2004), a história oral pode ser definida como método de investigação científica, como fonte de pesquisa de campo, ou, ainda, como técnica de produção e tratamento de depoimentos gravados. As falas tomadas no âmbito da história oral permitem ao pesquisador o acesso a informações/pistas sobre aspectos de difícil apreensão por outros caminhos investigativos, as experiências pessoais e impressões particulares sobre aquilo que se quer investigar.

A história oral ganha estatuto de método válido para a obtenção de informação no campo, na medida em que os conteúdos das falas obtidas pelos sujeitos da pesquisa extrapolam os sentidos e significados que pretendem expressar conscientemente. Por sua vez, o "sentido do que foi dito" deve ser "extraído" do material empírico, de forma consciente pelo pesquisador, e analisado de maneira que não distorça o que os sujeitos disseram ou queriam dizer.

De acordo com Thompson (1992, p. 137),

A evidência oral, transformando os 'objetos' de pesquisa em ‘sujeitos', contribui para uma informação que não só é mais rica, mais viva e mais comovente, mas, também, mais verdadeira (grifos do autor), 
pois são os sujeitos que dão forma e conteúdo às narrativas, à medida que interpretam suas próprias experiências e o mundo no qual elas são vividas.

A história oral como fonte de pesquisa de campo em Geografia Humanista tem um quadro amplo de técnicas aplicáveis à coleta de informações, como: depoimentos, relatos, entrevistas, biografias, história de vida etc. Seja qual for a técnica escolhida devemos considerar que as fontes orais são dotadas de cinco características principais: oralidade, forma narrativa, subjetividade, credibilidade diferente da memória e relação entre pesquisador e pesquisado.

Ainda no que se refere à escolha da técnica para coleta de informação em história oral, optamos pelo depoimento de pessoas que vivenciam diariamente o rio das Contas, em Itacaré, com o objetivo de saber: o que é o rio para elas, se se identificam com o rio, se têm afetividade por ele e o que o rio significa para elas.

Entretanto, não formulamos questões para a coleta dessas informações em campo, pois a técnica do depoimento não requer que o faça, mas, durante sua aplicação pedíamos que às pessoas falassem sobre o rio das Contas, seu sentimento por ele etc., na busca das informações e sua compreensão, em toda a sua complexidade e em seu acontecer. Isto é, não criamos artificialmente uma situação para ser pesquisada em campo, mas fomos ao encontro da realidade no seu acontecer, no cotidiano das pessoas de Itacaré.

Quanto à técnica da observação, também é considerada uma coleta de dados para conseguir informações sobre determinados aspectos da realidade, pois proporciona ao pesquisador um contato mais direto com a realidade social e, também, ajuda-o a identificar os sujeitos da sua pesquisa. Segundo Chiapetti (2010, p. 149):

Esta técnica é denominada observação assistemática, o que quer dizer que o pesquisador procura recolher e registrar os fatos da realidade sem a utilização de meios técnicos especiais, ou seja, sem planejamento ou controle. Geralmente este tipo de observação é empregado em estudos exploratórios, com abordagens descritivas que procuram captar informações subjetivas.

Laville e Dionne (1999, p. 176) explicam que a observação como técnica de pesquisa de campo não é a contemplação passiva e um simples olhar atento a que ou a quem queremos observar, mas um olhar ativo sustentado pelo problema e pelos objetivos da pesquisa: "A preocupação de pesquisa guiará o olho e o ouvido do pesquisador e o levará a ater-se a tal $[. .$.$] aspecto ou elemento".$ 
Feita esta abordagem teórica sobre a escolha do método da história oral, da técnica do depoimento e observação como coleta de dados na pesquisa de campo, passaremos a explicar os procedimentos metodológicos: como fizemos a seleção dos sujeitos da pesquisa, como colhemos os depoimentos desses sujeitos e, ainda, como realizamos o percurso nas águas do rio das Contas, para observar e registrar em fotografias as paisagens vividas pelas pessoas de Itacaré.

\section{A SELEÇÃo dOS SUJEITOS DA PESQUiSA E A COLETA DAS INFORMA- ÇÕES}

Como esta pesquisa se pauta numa abordagem qualitativa foi necessária uma aproximação, ou melhor, uma imersão no campo para nos familiarizarmos com a situação e com os sujeitos. Para tanto, fomos a Itacaré, preocupando-nos primeiramente em observar geograficamente o lugar, para conhecer lugares que ainda não conhecíamos, para conversar com as pessoas, para caminhar pela cidade e pelo distrito de Taboquinhas, para "sentir o lugar", para registrar paisagens em fotografias, para buscar informações e, muito importante, para navegarmos pelo rio das Contas.

Partindo do método da história oral, com a opção pela técnica do depoimento, reportamo-nos ao objeto da pesquisa, ou seja, a percepção do rio das Contas pelas pessoas que moram próximas a ele e, então, começamos "a pensar" sobre a seleção dos sujeitos que iríamos ouvir em campo, ou seja, aqueles que vivenciavam diretamente o rio das Contas em Itacaré. Sabíamos que a opção por determinadas pessoas deveria estar vinculada à necessidade de que elas deveriam falar sobre suas experiências de vida, seus sentimentos, suas visões de mundo e, principalmente, sobre o rio das Contas.

Decidimos colher os depoimentos de pessoas residentes na cidade de Itacaré, no distrito de Taboquinhas e, também, de pessoas que trabalhavam em restaurantes e que moravam em fazendas e comunidades ao longo do rio das Contas, principalmente porque é marcante a presença de fazendas de cacau (FIGURA 3) e de Comunidades Quilombolas Rurais, nas duas margens do rio.

Como não somos de Itacaré e, por isso, não conhecíamos as pessoas do lugar, antes de iniciarmos a coleta dos depoimentos consideramos oportuno pedir auxílio a um itacareense, assim poderíamos ter um fácil acesso aos locais e aos sujeitos da pesquisa. Este itacareense se tornou nosso guia e, sendo morador do distrito de Taboquinhas, conduziu-nos pelo local e apresentou-nos pessoas para participar da pesquisa de campo. 
FIGURA 3 - Fazenda cacaueira na beira do rio das Contas, em Itacaré, sul da Bahia

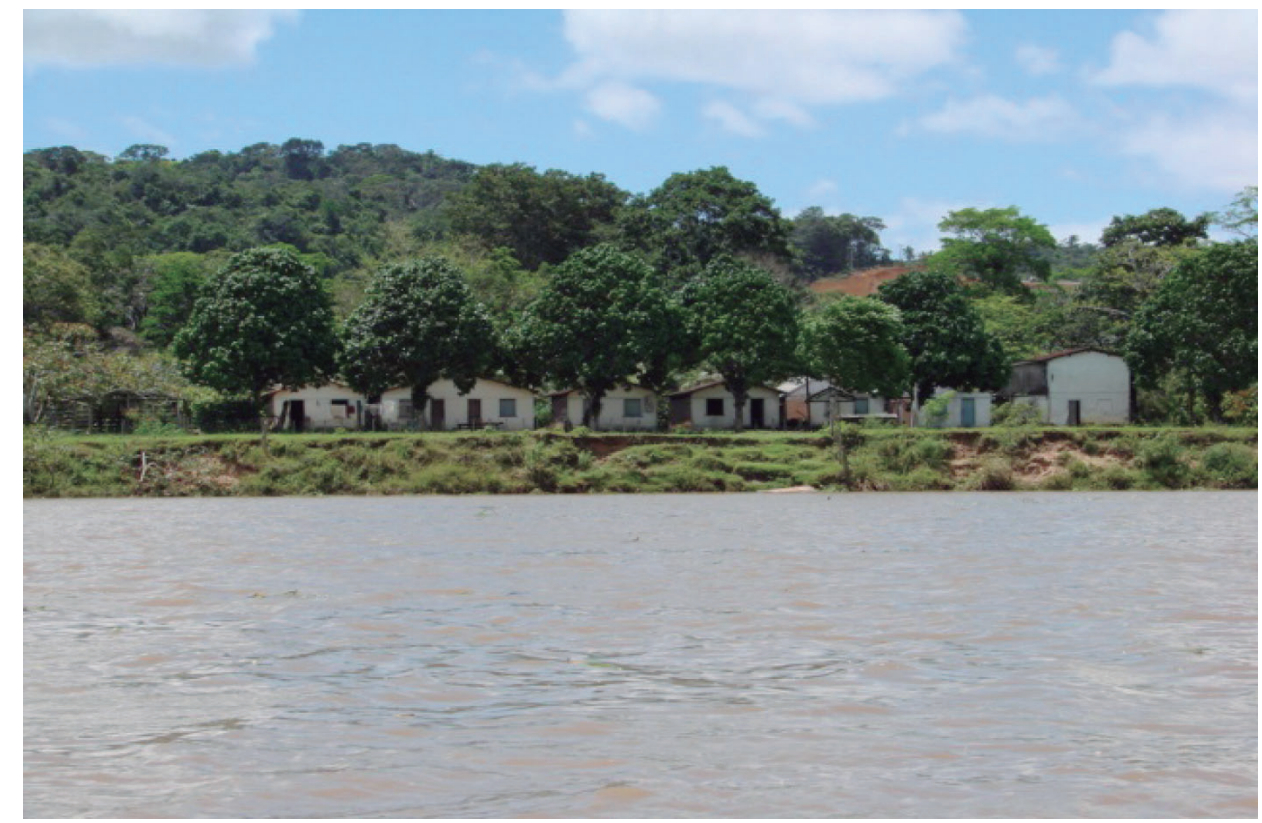

Fonte: Rita Jaqueline Nogueira Chiapetti.

Iniciamos, então, por Taboquinhas (FIGURA 4), já que “o tempo estava bom" e por isso poderíamos seguir pela estrada de terra, rodovia BA 654, que liga o distrito à cidade. Taboquinhas é um distrito de Itacaré que já teve muita importância econômica para o município no período áureo do cacau (décadas entre 1950 e 1980), quando o trecho da rodovia estadual BA ooı (chamada também de Rodovia Gabriela), que conecta Itacaré a Ilhéus, ainda não era pavimentado. Tal distrito chegou a ter maior importância econômica do que a própria cidade de Itacaré.

Depois que a pavimentação da BA oo foi concluída, em 1998, Itacaré passou a "se relacionar" diretamente com Ilhéus, município localizado ao sul de Itacaré. Com relação ao distrito de Taboquinhas, como está localizado no oeste do município de Itacaré, ficou abandonado e, espacialmente, marginalizado. Entretanto, desde o ano de 2000 , aproximadamente, o município de Itacaré tem recuperado "seu valor" em função da presença da Mata Atlântica, das belas praias e do turismo de aventura praticado por turistas no rio das Contas.

Começamos, de fato, a nossa pesquisa de campo, andando pelas margens do rio das Contas no trecho de Taboquinhas, pela "prainha" de areia branca que se forma em sua margem (FIGURA 5). 
FIGURA 4 - Margem direita do rio das Contas, no distrito de Taboquinhas, município de Itacaré, sul da Bahia

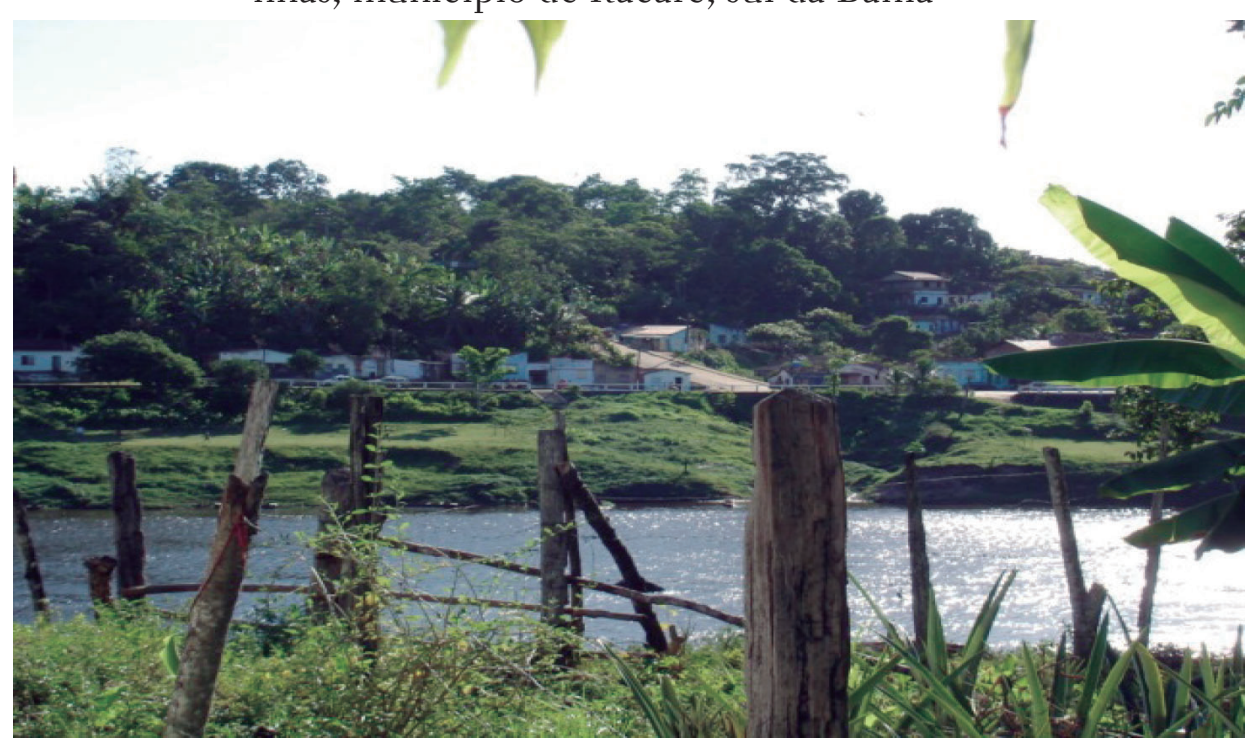

Fonte: Rita Jaqueline Nogueira Chiapetti.

FIGURA 5 - "Prainha" do rio das Contas, no distrito de Taboquinhas, município de Itacaré, sul da Bahia

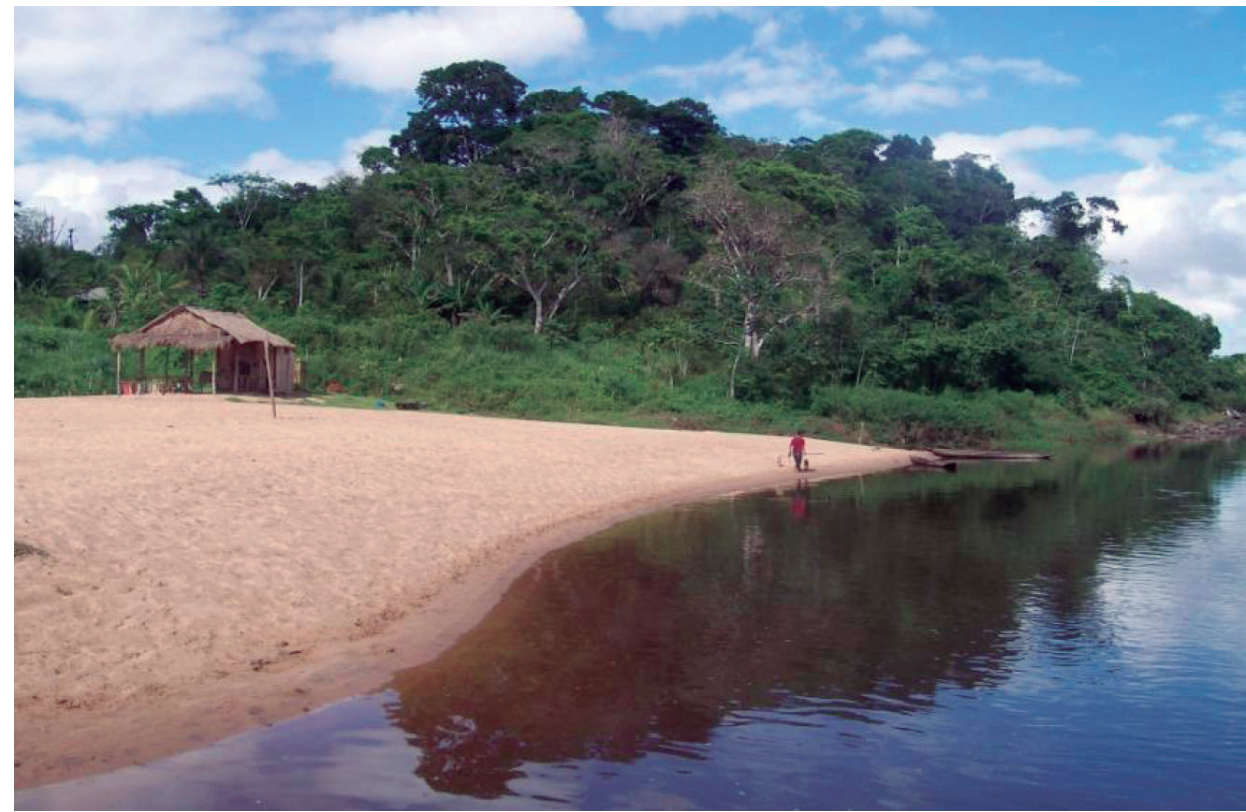

Fonte: Rita Jaqueline Nogueira Chiapetti. 
Também fomos conhecer e fotografar cachoeiras, corredeiras e o cânion, sem pensar em "entrar" na aventura do rafting no rio das Contas, pois convites não faltaram. Andamos pelas ruas do distrito, observando pessoas, casas, igrejas, aspectos da vegetação e do relevo, muito íngreme, mas, principalmente, buscando uma aproximação com as pessoas do lugar. Chegamos até a iniciar um passeio de canoa pelas águas do rio das Contas, no trecho em que cruza o distrito, mas o medo de navegar numa embarcação tão pequena nos fez abortar a aventura.

O passo seguinte foi a escolha dos sujeitos da pesquisa entre a população de Taboquinhas, que nos recebeu muito bem, principalmente por estarmos acompanhadas por uma pessoa do lugar, pois, antes de qualquer coisa, nosso guia sempre conversava com as pessoas sobre assuntos cotidianos. Assim, ele nos foi apresentando a mulheres e homens taboquinhenses: lavadeiras de roupas, pescadores, donas de casa, funcionários públicos, guias de rafting, professores, etc. Ao mesmo tempo em que íamos sendo apresentadas a esses sujeitos, íamos convidando-os para participar da nossa pesquisa. Importante registrar que nosso critério para seleção dos sujeitos era que todos deveriam ter uma participação espontânea (alguém que faz por si mesmo, sem ser incitado ou constrangido por outro; pessoa voluntária; pessoa de livre vontade).

Mas, antes de iniciarmos a coleta dos depoimentos nos voltamos para Bourdieu (1999), que escreve: para se obter uma narrativa natural, muitas vezes, não é interessante fazer uma pergunta direta, mas, sim, fazer com que o pesquisado relembre parte de sua vida. Para tanto, o pesquisador pode muito bem ir suscitando a memória do pesquisado. Então, decidimos proceder de acordo com o pensamento desse autor, pois o processo de relembrar das pessoas é um meio de explorar os significados subjetivos da sua experiência vivida no lugar. Isso nos levou a considerar as razões que os levaram a construir suas memórias de determinada maneira ou, ainda, a dizer em seus depoimentos o que sentem com relação ao rio das Contas.

Ficamos cinco dias em Taboquinhas e colhemos depoimentos de quatorze (14) pessoas. Resolvemos parar quando percebemos que as suas falas estavam ficando muito parecidas e, por isso, não havia necessidade de continuar, pois não estava mais havendo acréscimo de informações relevantes à pesquisa, ou melhor, todos estavam começando a dizer as mesmas coisas. Neste caso é porque houve uma saturação, ou seja, a partir de certo número de depoimentos coletados, os posteriores não iriam acrescentar mais nada ao que os outros expressaram. Também, numa metodologia de base qualitativa, o número de sujeitos que deve participar da 
pesquisa de campo dificilmente pode ser determinado, pois tudo depende da qualidade das informações obtidas em cada depoimento, assim como da heterogeneidade destas informações.

Enfim, enquanto estavam "aparecendo" dados ou informações originais ou pistas que poderiam indicar novas perspectivas à nossa investigação, os depoimentos foram sendo colhidos. Mas, paramos quando percebemos que não estava havendo mais nada de novo nas suas falas. Esse foi nosso critério para a quantidade de sujeitos da pesquisa no lugar.

Importante registrar mais alguns procedimentos que tivemos em Taboquinhas: em todas as conversas com os sujeitos, sempre tomamos muito cuidado para que suas falas fossem livres, buscando não interferir na qualidade dos depoimentos. Recorremos novamente a Bourdieu (1996), que chama a atenção para o cuidado na relação pesquisador/pesquisado, evitando e/ou ficando atento para a possibilidade de uma criação artificial de sentido do relato oral. Assim, tomamos cuidado para não conduzir os depoimentos, de modo que os sujeitos falassem o que queríamos ou precisávamos ouvir para desenvolver nossa pesquisa.

Também informamos a esses sujeitos sobre a finalidade da pesquisa, bem como sua contribuição, ou seja, que seus depoimentos seriam muito importantes para que a pesquisa pudesse ser desenvolvida e, ainda, que sem eles nossa pesquisa não seria realizada. Perguntamos, também, se seus depoimentos poderiam ser gravados, apenas para que não se perdesse nada dos seus conteúdos, mas que seriam transcritos da forma como foram falados e só depois seriam utilizados como informações colhidas em campo, para alcançar os objetivos da pesquisa. Todas as pessoas que se dispuseram a participar não colocaram nenhum empecilho, ao contrário, foram muito solícitas, inclusive até não se opondo a que fossem citados seus nomes, se assim quiséssemos.

Algumas vezes percebemos que alguns sujeitos da pesquisa não entendiam (ou por timidez) quando pedíamos para falarem sobre o rio das Contas, sobre seus sentimentos com relação a ele. Nesses casos, fazíamos perguntas diretas, formuladas no momento, como exemplo: O que é o rio das Contas para você? O que o rio significa para você? O que mais gosta no rio? O que menos gosta no rio? Se fechar os olhos e pensar no rio, o que "vem" na sua cabeça? Apesar de concordarmos com Bourdieu (1999, já citado), essa foi a melhor maneira para colher informações dessas pessoas de Taboquinhas, pois a maioria delas era muito simples e desconfiada.

A nossa presença no distrito de Taboquinhas, nesses dias, foi importante para a pesquisa porque pudemos conhecer melhor o lugar e isso 
contribuiu para a qualidade das informações coletadas. Segundo Chizotti (1991), a imersão do pesquisador nas circunstâncias e contexto da pesquisa é fundamental, a saber, o mergulho nos sentidos e emoções; o reconhecimento das pessoas como sujeitos que produzem conhecimentos e práticas; as informações colhidas como fruto de um trabalho coletivo resultante da dinâmica entre pesquisador e pesquisado; a aceitação de que tudo que foi vivido pelo pesquisador, em campo, foi precioso e importante: a constância e a ocasionalidade, a fala e o silêncio, a continuidade e a ruptura, as revelações e até mesmo o que permaneceu oculto.

Enfim, os dias vividos em Taboquinhas foram uma grande experiência por fazermos, na prática, de fato, uma Geografia Humanista, pois convivemos com as pessoas do lugar, vivenciando o cotidiano do lugar: muito cedo já observávamos alguns taboquinhenses indo e vindo pelas ruas, varrendo suas calçadas, conversando com seus vizinhos, esperando o ônibus para Itacaré... Percebemos que a população de Taboquinhas vive a vida com características muito peculiares de um lugar pacato, com um tempo próprio, que se move no mesmo movimento do rio das Contas... (FIGURA 6).

FIGURA 6 - Paisagem do distrito de Taboquinhas, município de Itacaré, sul da Bahia

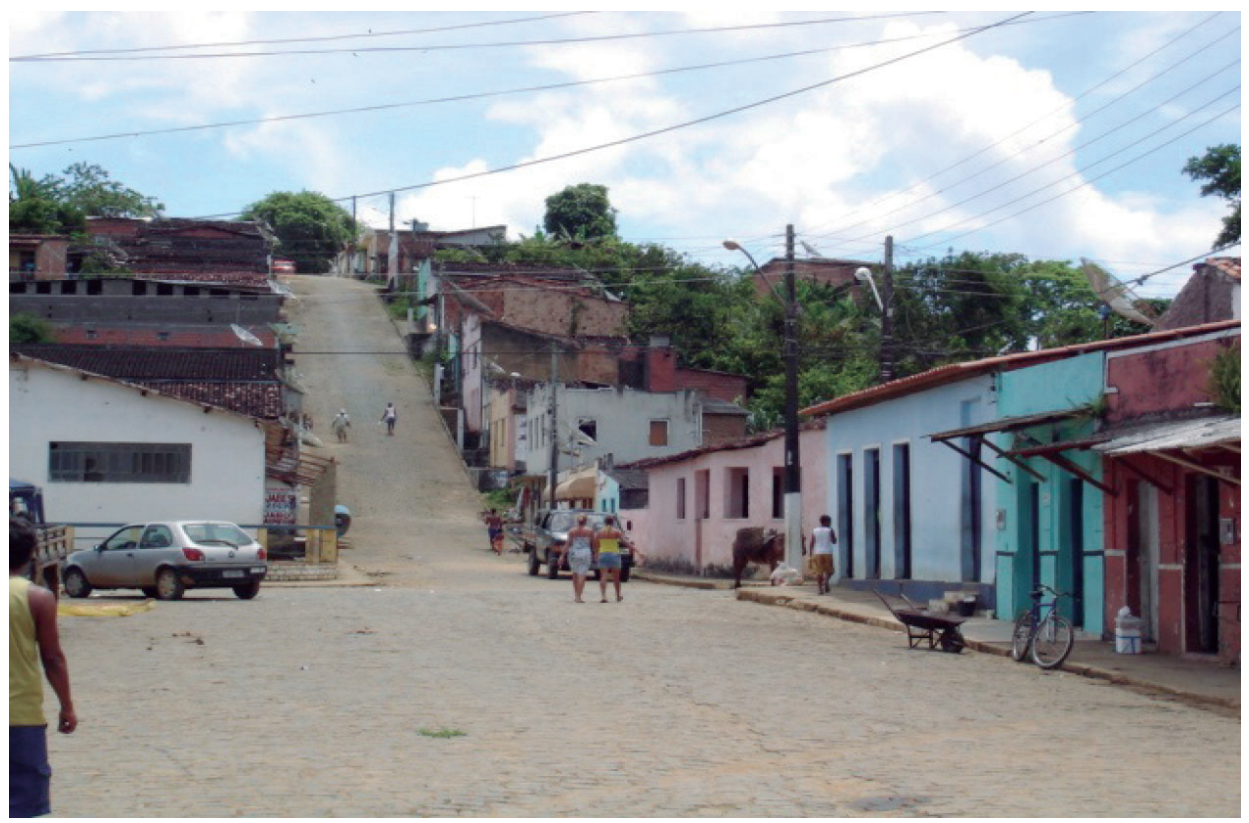

Fonte: Rita Jaqueline Nogueira Chiapetti. 
Dando continuidade à pesquisa de campo, retornamos para a cidade de Itacaré. Neste local, ficamos mais três dias e colhemos os depoimentos de donos e funcionários de pousadas, pois sabíamos da importância do rio das Contas para a atividade turística local e regional. Também colhemos o depoimento do presidente e instrutor da Associação de Canoagem de Itacaré, visto que os associados praticam tal esporte no rio das Contas (FIGURA 7). E, ainda, colhemos os depoimentos da diretora do Instituto de Turismo de Itacaré (ITI), de um instrutor de rafting, de um guia turístico, de um pescador e de uma líder comunitária, somando oito (o8) depoimentos. Da mesma forma que ocorreu em Taboquinhas, usando os mesmos procedimentos, realizamos mais esta etapa da pesquisa de campo.

FIGURA 7 - Canoagem no rio das Contas, em Itacaré, sul da Bahia

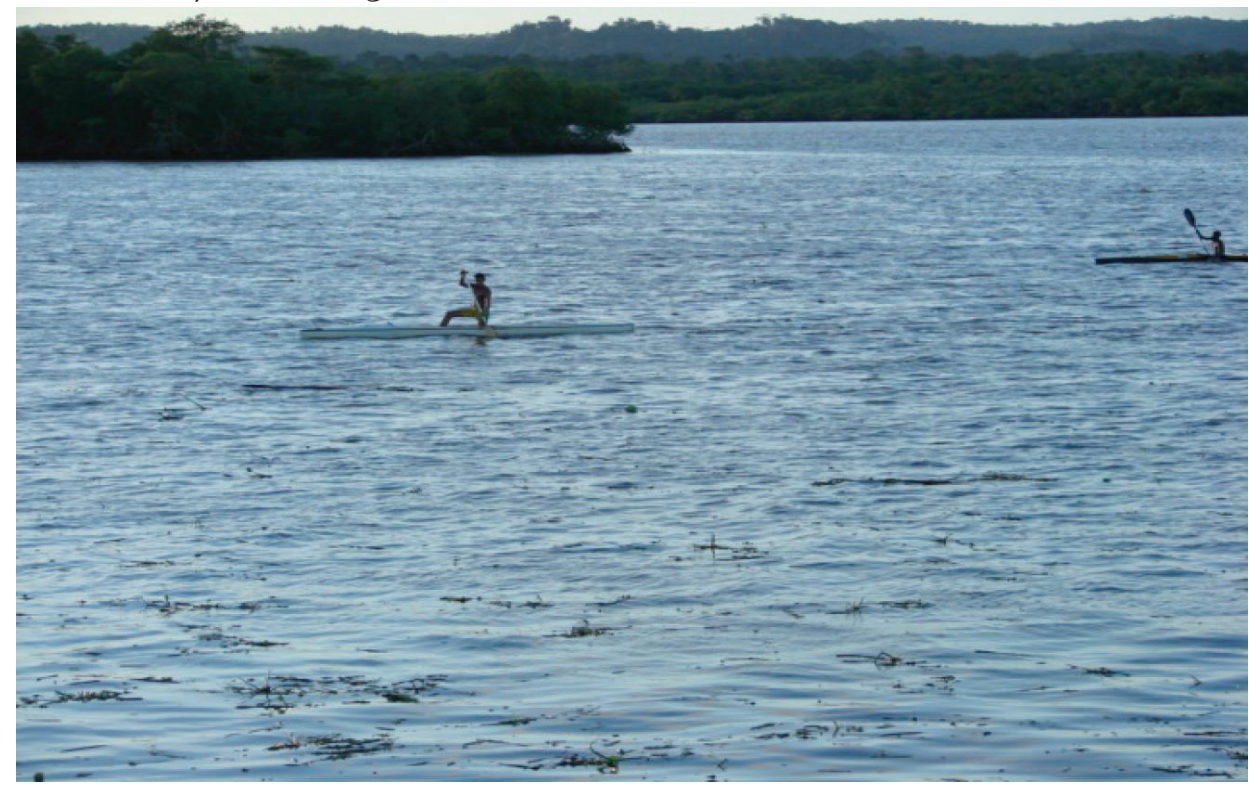

Fonte: Rita Jaqueline Nogueira Chiapetti.

Ainda faltava colher os depoimentos de pessoas ao longo do rio: trabalhadores de restaurantes e de fazendas cacaueiras e moradores de Comunidades Quilombolas Rurais, localizadas nas margens do rio das Contas. Sabíamos que essa etapa seria a mais difícil de ser cumprida, devido ao custo, à necessidade de auxílio de outras pessoas para navegarmos pelo rio, além do tempo necessário para cumpri-la.

Então, recorremos a uma instituição que atua em Itacaré (optamos por não identificá-la) para solicitar apoio, o que foi uma decisão muito acertada, 
pois, na semana seguinte, um grupo de pesquisadores iria até uma das comunidades situadas ao longo do rio fazer uma reunião com as lideranças de todas as Comunidades Quilombolas Rurais, para discutir a possibilidade da instalação de energia elétrica pelo Governo Federal (Programa Luz para Todos). Fomos, então, convidadas a acompanhar esse grupo, quando teríamos a oportunidade de navegar pela primeira vez nas águas do rio das Contas.

Chovia muito em toda a região, mas o dia marcado para irmos até a Comunidade Quilombola Rural João Rodrigues (margem esquerda do rio das Contas) havia chegado e, mesmo com chuva, partimos para o nosso destino. Fomos num barco de um pescador que ia, a todo o momento, "pegando" pessoas de outras comunidades para participarem da tal reunião.

Esta oportunidade de navegarmos junto com alguns moradores das margens do rio das Contas teve um valor sem igual para nossa pesquisa, pois ao mesmo tempo em que curtimos aquela situação única, observamos as margens do rio e aproveitamos para conversar com as pessoas que estavam no barco a respeito das suas experiências no rio, de suas vidas e, também, para contarmos sobre nós, pois tinham muita curiosidade para saber quem éramos, o que fazíamos e o que pretendíamos ao estar ali. Essa situação perdurou até chegarmos ao nosso destino e, mais uma vez, para a nossa pesquisa de campo, foi uma grande contribuição estarmos presentes nesta reunião, pois pudemos conhecer pessoas e seus modos de vida nesta comunidade beira-rio, além de colher mais quatro (4) depoimentos.

Antes de retornarmos à cidade de Itacaré saboreamos uma deliciosa feijoada quilombola feita pelas mulheres da comunidade. Esse momento foi muito importante para nossa pesquisa de campo conduzida pelos propósitos da Geografia Humanista, porque pudemos vivenciar a grande expectativa que essas pessoas tinham quanto à chegada da energia elétrica em suas comunidades, tanto que, para alguns, esse fato marcaria o início de uma nova vida.

Porém, ao regressarmos ao rio das Contas para o barco que nos trouxera, aconteceu um fato que não poderíamos deixar de relatar, já que, ao fazermos uma pesquisa de campo, podemos passar por diversos tipos de situações ou acontecimentos, tal como este. Como chovia demasiadamente e, por consequência, havia muita lama nas margens do rio, fomos levadas a um afluente com a certeza de que esse caminho estaria menos perigoso. Subimos, então, em uma canoa para irmos até o barco que estava a nossa espera. Navegamos por poucos metros até chegarmos ao rio das Contas, quando nos assustamos com a sua forte correnteza, desequilibrando a canoa, que virou. Depois do grande susto com o mergulho no rio, todos riram muito da situação e disseram que fomos "batizadas" nas águas do rio das 
Contas. Portanto, se é preciso "mergulhar" na pesquisa e desenvolvê-la com paixão, o primeiro "mergulho" foi dado neste momento!

Mas, como tínhamos ido somente a uma comunidade da beira do rio, ainda faltavam os depoimentos dos sujeitos das demais Comunidades Quilombolas Rurais, das fazendas de cacau e dos restaurantes, o que vai ser relatado no próximo item, pois tais depoimentos foram colhidos no mesmo dia em que navegamos novamente no rio, para observarmos geograficamente as suas margens (FIGURA 8), a população ribeirinha e registrar algumas paisagens.

FIGURA 8 - Mata Atlântica na margem do rio das Contas, em Itacaré, sul da Bahia

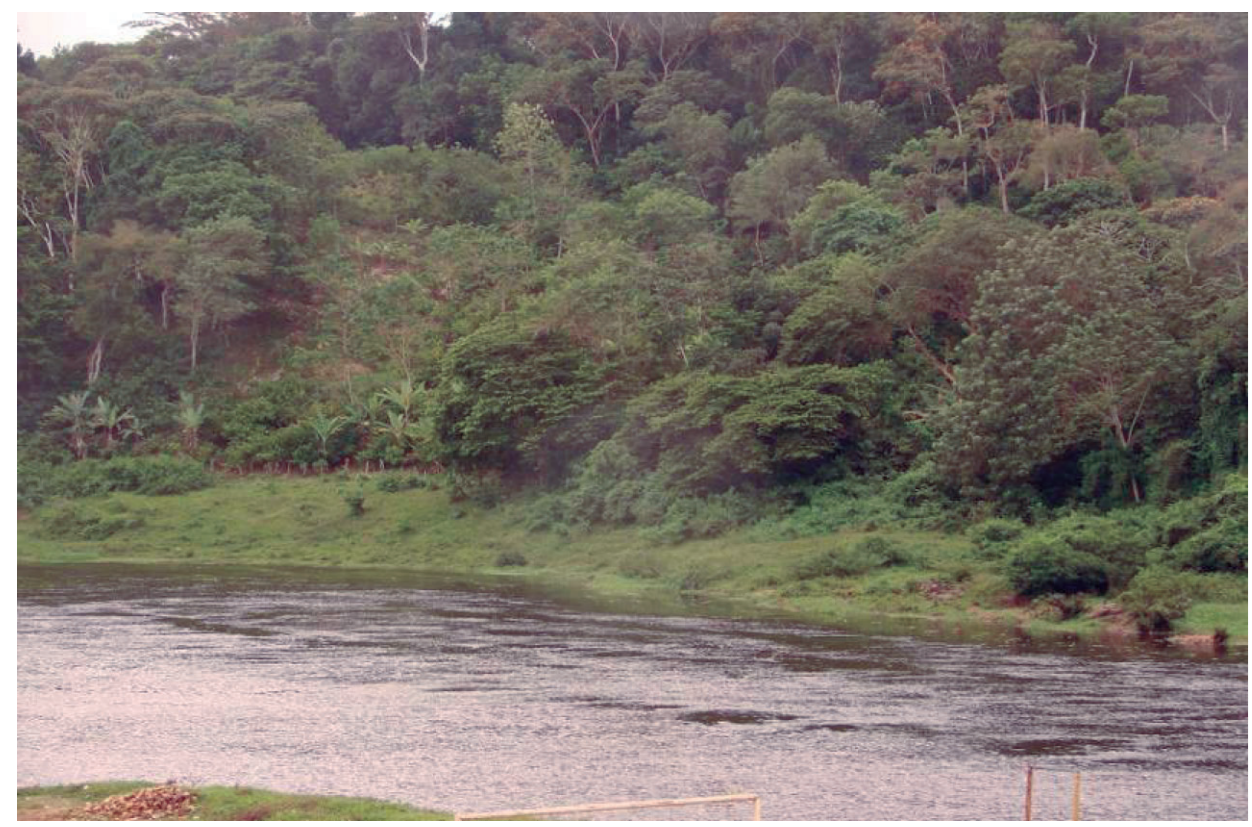

Fonte: Rita Jaqueline Nogueira Chiapetti.

\section{CONTINUANDO... A COLHER INFORMAÇÕES EM CAMPO}

Como em nosso planejamento inicial da pesquisa de campo ainda faltava navegarmos pelo rio das Contas até o distrito de Taboquinhas, fazendo observação de suas margens e, ainda, registrando paisagens do rio em fotografias, resolvemos pedir auxílio a uma moradora e líder comunitária de Itacaré, que conhecia muito bem o rio e as pessoas do lugar, além de ser querida por todos, na região. Ela imediatamente se colocou à nossa 
disposição, apresentando-nos alguns condutores de barco de Itacaré, para contratarmos um que nos conduzisse pelas águas do rio das Contas, desde a cidade até o distrito de Taboquinhas.

Depois de conhecer alguns desses barqueiros, optamos por aquele que nos pareceu ter "maior experiência no rio" e que nos deu maior segurança, pois deixou bem claro que, se não parasse de chover e o volume de água do rio não diminuísse um pouco, não seria possível fazer tal percurso. Isso confirmou sua experiência no rio e nos deixou mais seguras.

Mesmo assim, aproveitamos esse momento para conversar com alguns barqueiros, que eram pescadores do mar e, também, do rio. Todos tiveram muita disposição em contar suas histórias de vida, seus medos e alegrias sentidos no rio, e suas preocupações com o seu futuro e o futuro do rio. Consideramos estes "bate-papos" somente como conversas informais, pois não estávamos preparadas para registrá-las no momento.

Enquanto aguardávamos o tempo melhorar, nossa guia nos conduziu pelas ruas da cidade de Itacaré, mostrando "o seu lugar" (como ela mesma disse). Um grande privilégio! É assim que podemos nos referir à sua companhia. Foi como penetrar no mundo das pessoas do lugar, conhecendo seus diversos olhares sobre a vida... sobre o rio... captando imagens do lugar (FIGURA 9), vivenciando o espírito do lugar.

FIGURA 9 - "Baba" ${ }^{2}$ na beira do rio das Contas, na cidade de Itacaré, sul da Bahia

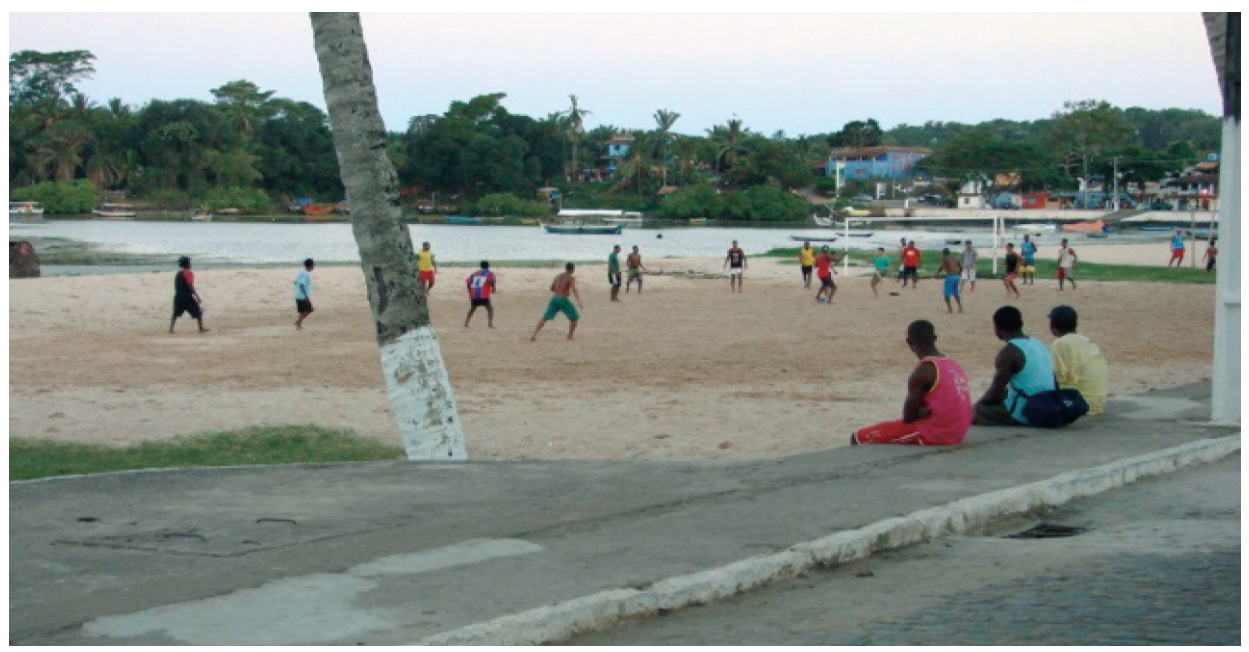

Fonte: Rita Jaqueline Nogueira Chiapetti.

Futebol entre amigos. 
Como a chuva não cessava e, consequentemente, o nível do rio das Contas subia muito (como os itacareenses dizem: "o rio tá com água"), aproveitamos o momento para realizar levantamentos de dados e informações junto às instituições e entidades que desenvolviam trabalhos em Itacaré e até mesmo no próprio rio. Fomos novamente ao ITI, uma das principais instituições defensoras da conservação do rio das Contas; fomos à Prefeitura de Itacaré, à sede da Associação de Canoagem do rio das Contas e às empresas de turismo que oferecem atividades esportivas no rio. Todos esses contatos resultaram em muitas informações sobre o rio, para nosso trabalho escrito, que seria redigido posteriormente.

A preocupação com a chuva nos acompanhou até o final da semana, quando finalmente o sol voltou a brilhar. Assim, logo na segunda-feira fomos ao encontro do condutor de barco, conforme havíamos combinado. Ele já nos esperava para navegarmos pelas águas do rio das Contas, sendo que nosso principal propósito seria ampliarmos nosso olhar geográfico sobre o lugar da pesquisa.

Era um barco pequeno, mas acomodou a todos: ele, eu e a moradora local (nossa guia pelas águas do rio das Contas), que nos auxiliava neste difícil e prazeroso trilhar da pesquisa de campo. O rio ainda "estava com água”, mas seu nível já havia baixado um pouco, de modo que iríamos tentar navegar. Caso se tornasse perigoso em algum trecho, retornaríamos sem demora! Já havíamos nos informado e por isso sabíamos que o condutor que nos levaria era um "mestre em rio das Contas", pois conhecia a sua vida, seus sofrimentos, suas alegrias... enfim, vivia a vida no/do rio.

Iniciamos o percurso no rio em frente à cidade de Itacaré e, sempre navegando a montante e munidas de câmera fotográfica, fomos desvendando-o com o olhar nas suas margens, na forte correnteza da sua água marrom devido aos sedimentos, nas "baronesas"3 que insistiam em enroscar no motor do barco, deixando-nos apreensivos em alguns momentos. Mas, com coragem, seguimos, ouvindo algumas histórias do rio e das pessoas do rio, contadas por nossa guia. De olhos bem abertos, fomos observando e coletando informações sobre as paisagens do rio, ora nas sedes das fazendas cacaueiras, ora nas plantações de cacau, embaixo da Mata Atlântica. Também observamos os restaurantes e as Comunidades Quilombolas Rurais das margens do rio.

Tivemos a oportunidade de observar o novo trecho da rodovia estadual BA oor entre Itacaré e Maraú, passando por baixo da ponte sobre o rio das Contas, inaugurada em 2009. E, assim, navegamos... algumas

3 Nome popular regional da planta aquática Aguapé. 
vezes em silêncio, mas sempre com o olhar dirigido a tudo e a todos, procurando ouvir a "voz do rio"... captar as suas imagens...

Na semana anterior havíamos marcado com uma proprietária de uma fazenda da margem direita do rio, próximo à Volta do Poço (local onde o rio faz uma curva acentuada e a profundidade do seu leito aumenta), para fazermos essa "visita da pesquisa". Quando estávamos bem perto dessa fazenda, que fica aproximadamente na metade do percurso entre a cidade de Itacaré e o distrito de Taboquinhas, nosso condutor alertounos que estava ficando muito perigoso prosseguirmos, pois a correnteza aumentava e o volume de "baronesas" também. Então, sem discutir, decidimos ir somente até esta fazenda e, depois, retornar à cidade de Itacaré.

Chegando lá, a simpática e acolhedora anfitriã nos aguardava com um saboroso café servido na varanda de sua casa, construída próxima à margem direita do rio. Neste trecho, o rio se encontra bem encaixado em seu vale, devido ao relevo de montanha do Planalto Costeiro. Realmente, a paisagem era linda, tanto que construíram uma espécie de choupana bem próxima à margem, somente para curtir/apreciar a paisagem da Volta do Poço. Depois de conversarmos e conhecermos o lugar, perguntamos à proprietária se poderíamos colher alguns depoimentos em sua fazenda, já que os trabalhadores locais experienciavam o rio todos os dias, há muito tempo. Com a sua autorização iniciamos a coleta dos depoimentos, primeiramente ouvindo ela própria e, depois, alguns funcionários da fazenda, somando quatro (4) depoimentos.

O tempo passava e, ainda, precisávamos colher outros depoimentos e continuar a observar geograficamente o rio das Contas. Por este motivo agradecemos o acolhimento na fazenda e começamos o percurso de retorno. Mas, antes disso, nosso barqueiro, corajosamente, levou-nos à Volta do Poço, pois percebeu que para nós cada detalhe do/no rio era importante. Foi uma experiência maravilhosa navegarmos por esse trecho em que o rio fica muito largo, formando uma prainha de areia branca em sua margem direita. Já no lado esquerdo, a Mata Atlântica impera exuberante. Chegamos a nos sentir pequenos diante da grandeza da beleza da paisagem do rio! (FIGURA 10)

O percurso de volta para Itacaré teve o mesmo sentido das águas do rio... uma sensação de tristeza por estar chegando ao final daquele momento mágico, em que sentíamos pertencer ao rio, da mesma forma que as pessoas do lugar. Ao mesmo tempo tivemos uma sensação de alívio por tudo estar dando certo, mesmo que não tivéssemos conseguido fazer todo o percurso navegável do rio até Taboquinhas, para colher depoimentos e conhecer/observar o lugar, como estava previsto no planejamento. 
FIGURA 10 - Curva Volta do Poço, no rio das Contas em Itacaré, sul da Bahia

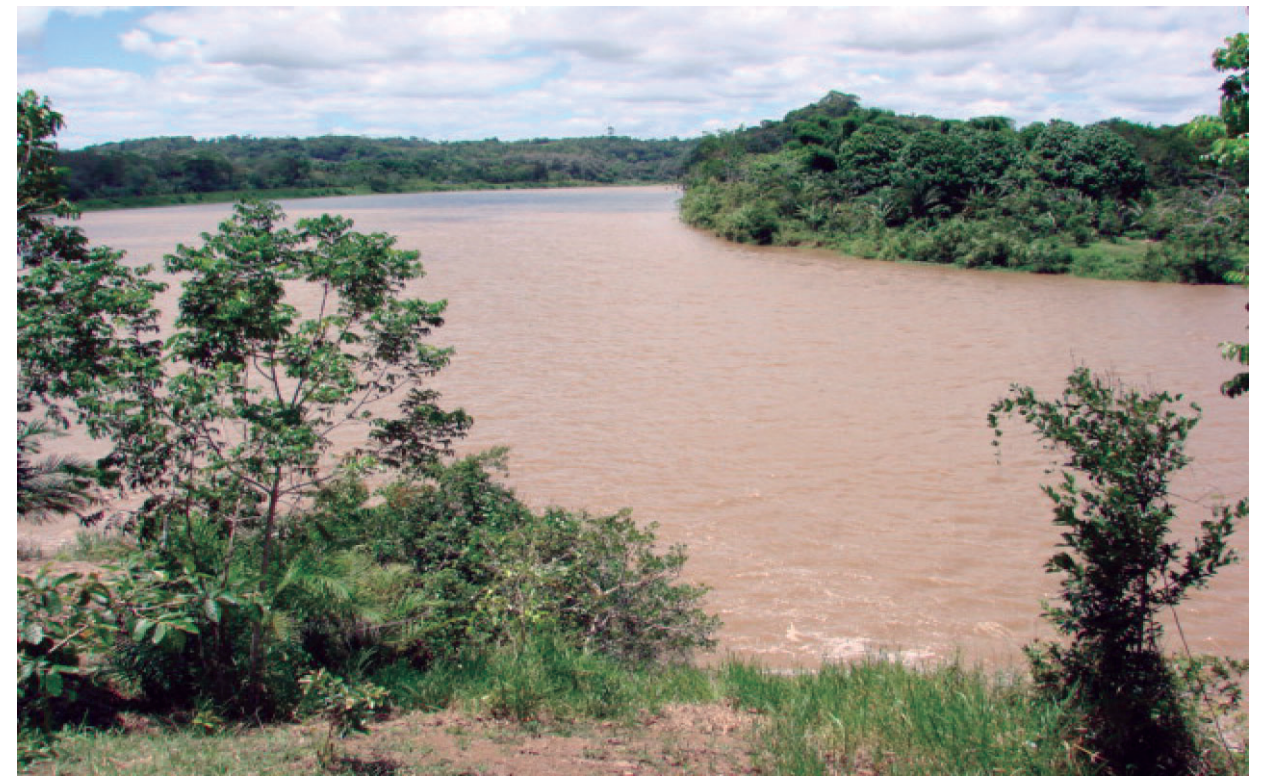

Fonte: Rita Jaqueline Nogueira Chiapetti.

Nesse momento, nossa guia nos falou sobre um senhor que era famoso por atravessar a cavalo o rio das Contas. Aproveitamos, então, esta característica peculiar para conhecer mais uma pessoa que havia nascido na beira do rio... seu modo de vida, seu lugar, um homem corajoso que, com sabedoria e montado em um cavalo, domava as águas do poderoso rio. Dele também, caso concordasse em participar da nossa pesquisa, colheríamos o depoimento.

Paramos, então, o barco na margem direita do rio e o simpático homem logo apareceu para nos receber, mesmo sem termos marcado a visita. Como nossa guia e o barqueiro o conheciam bem, não tivemos dificuldade alguma para conversar com ele. Ao contrário, mostrou-se muito receptivo ao nosso pedido para dar um depoimento, inclusive nos oferecendo uma fresquinha e deliciosa água de coco, além da polpa da fruta do cacau, enquanto ele falava do rio.

Já passava muito do meio-dia, mas continuamos nossa pesquisa de campo pelo rio das Contas, procurando ainda por detalhes que tinham nos escapado à vista, registrando tudo em fotografias. O nosso condutor do barco e a nossa guia insistiam em dizer que o rio não era sempre assim: com "água suja", com "baronesas", com muita água e forte correnteza. Ao mesmo tempo falavam que suas margens estavam se alargando, parecendo que o rio estava "comendo a terra" a cada enchente. Nós percebemos esse fenômeno ao ver 
algumas árvores (da mata ciliar) "deitadas" sobre o leito do rio, parecendo "beber da sua água”. Também observamos a presença de pássaros (FIGURA 11) nas margens do rio, compondo este cenário hídrico margeado pela mata.

FIGURA 11 - Pássaro no rio das Contas, em Itacaré, sul da Bahia

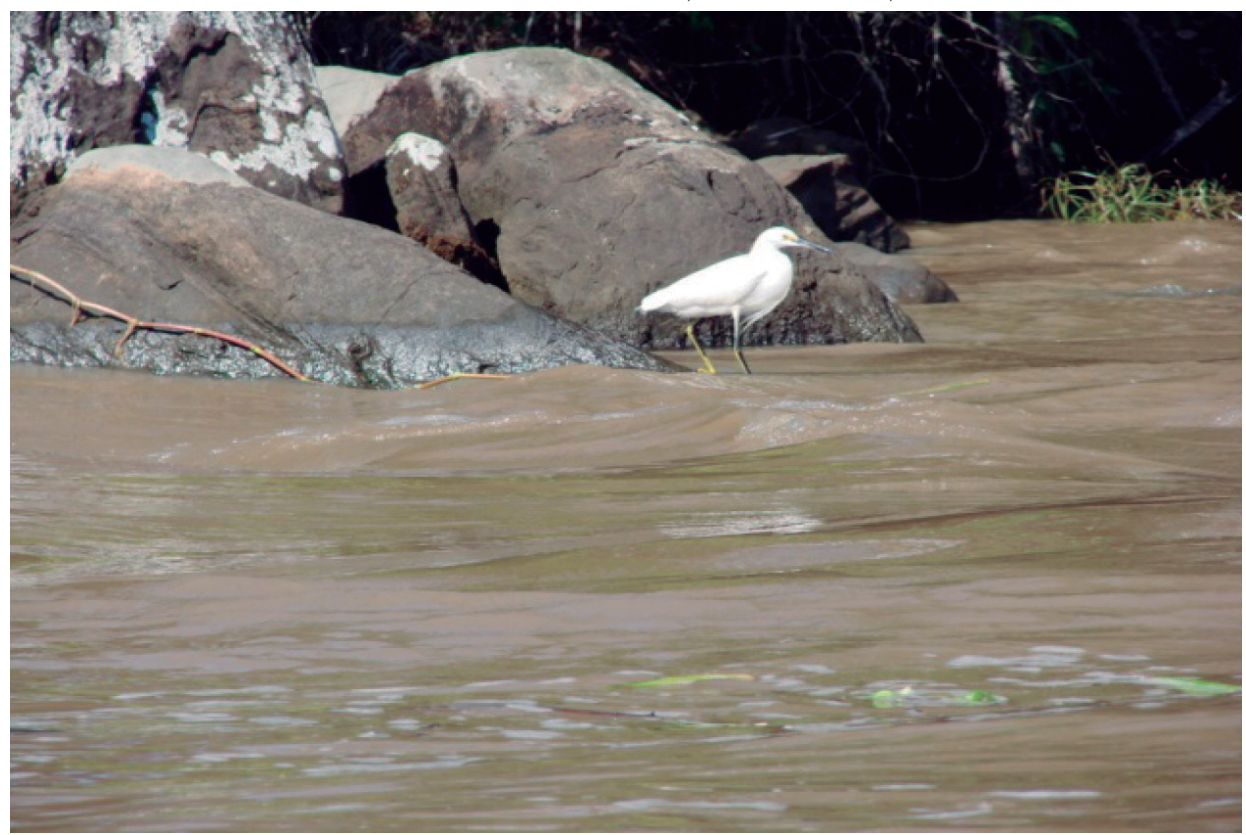

Fonte: Rita Jaqueline Nogueira Chiapetti.

Ao nos aproximarmos da Comunidade Quilombola Rural Santo Amaro, nossa guia perguntou se queríamos conhecê-la e conversar com as pessoas de lá. Assim, colhemos mais três (3) depoimentos desses quilombolas, os quais foram dados com muita timidez, pois em pouco tempo é difícil alguém "abrir seu coração" para quem não conhece.

Depois disso, seguimos até um restaurante localizado na margem direita do rio, já bem próximo à cidade de Itacaré. Da mesma forma, nossa guia e nosso condutor conheciam os proprietários, por isso, além de almoçarmos, aproveitamos para colher os depoimentos dessas duas (2) pessoas, sempre utilizando os mesmos procedimentos de pesquisa.

Nosso condutor do barco, atento, escutava cada conversa que tínhamos, e, parecia querer contar sobre sua experiência, pois já havia nos falado que conhecia muito bem o rio, que desde menino brincava e pescava nele e, depois que cresceu, o rio continuava fazendo parte do seu cotidiano, sendo o lugar do seu trabalho: pescar, levar e trazer turistas... Então, colhemos também seu depoimento (1). 
Deixamos o restaurante para trás e continuamos a observar e a registrar imagens do rio, navegando em direção ao "porto" final do nosso percurso, mas não sem antes contemplar a paisagem da cidade de Itacaré, vista do rio (FIGURA 12) e, ainda, chegar bem perto da sua foz, local em que a água do rio se mistura com a do mar, onde "o rio vira mar".

FIGURA 12 - Paisagem da cidade de Itacaré, vista do rio das Contas, sul da Bahia

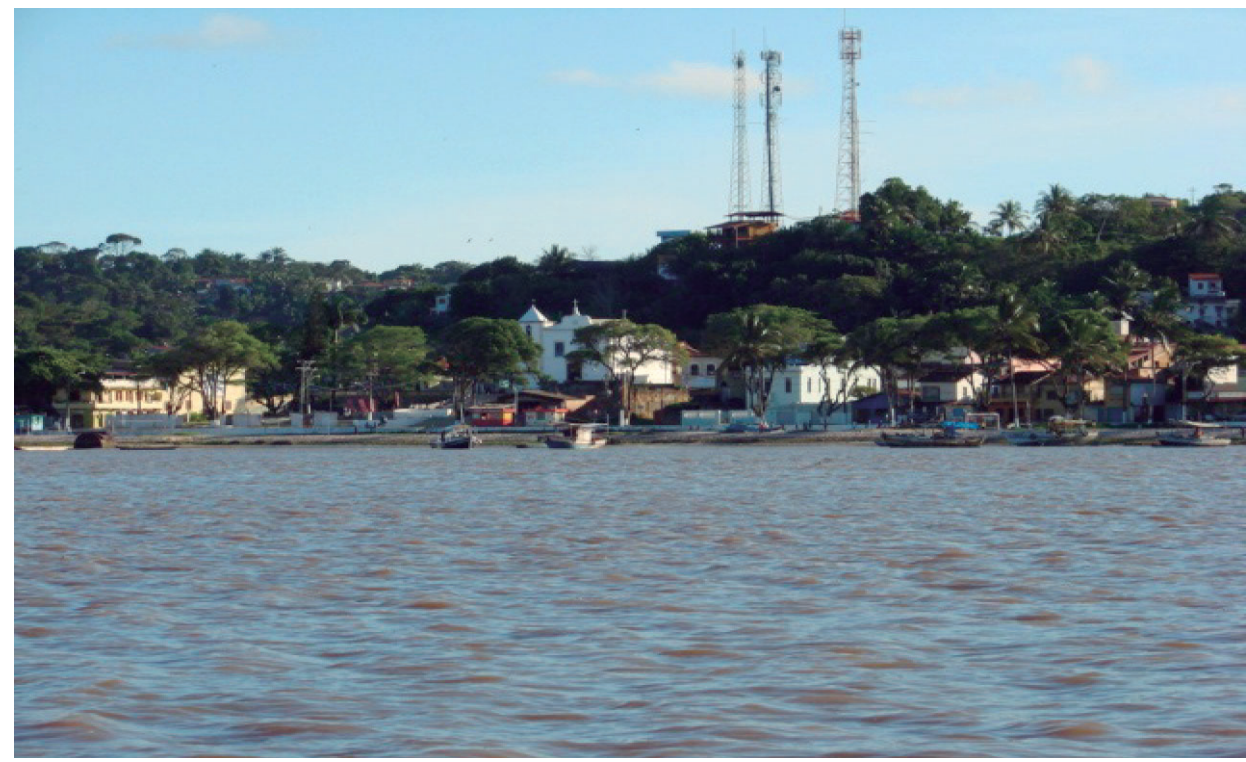

Fonte: Rita Jaqueline Nogueira Chiapetti.

E, assim, chegamos ao fim de mais esta etapa/experiência no rio das Contas, certas de que esse trilhar da pesquisa de campo foi cumprido com êxito, ainda mais por termos colhido onze (11) depoimentos dos sujeitos das margens do rio.

Por fim, é preciso considerar que, conforme Bourdieu (1998) assinala, os procedimentos da pesquisa devem anteceder à prática, apenas pelo fato de que é necessário planejar a pesquisa antes de fazê-la, mas de fato eles acabam sendo definidos com a prática.

Como não tínhamos conseguido ir às demais Comunidades Quilombolas Rurais das margens do rio nesta etapa da pesquisa, devido ao grande volume de água no período, fomos outro dia de carro pela estrada BA 654, que margeia o lado direito do rio das Contas, ligando Itacaré à Ubaitaba e Aurelino Leal, municípios do sul baiano divididos pelo rio das Contas e margeados pela BR 101 . 
Chegamos, então, à Comunidade Quilombola Rural de Acaris, localizada na sua margem esquerda, atravessando o rio no barco de um morador local. Utilizamos os mesmos procedimentos para colher os depoimentos de duas (o2) pessoas que se dispuseram a participar. Aproveitamos esse mesmo dia para visitar e conhecer a Comunidade Quilombola Rural do Fojo (margem direita), lugar em que colhemos mais dois (2) depoimentos.

É oportuno esclarecer que a etapa mais difícil da nossa pesquisa de campo e, ao mesmo tempo, mais prazerosa foi a coleta dos depoimentos ao longo do rio das Contas, pois, como foi relatado, passamos por diversas dificuldades. Mas, por outro lado, conhecemos o rio e "as pessoas do rio", com suas "histórias de vidas", navegamos por suas águas, vivenciamos situações no/do rio, além de contemplarmos paisagens registradas em suas margens.

O número de depoimentos colhidos ficou assim distribuído: quatorze (14) no distrito de Taboquinhas; oito (8) na cidade de Itacaré e dezenove (19) ao longo do rio, somando quarenta e um (41) depoimentos colhidos na pesquisa de campo qualitativa, pelas águas e margens do rio das Contas, no sul da Bahia.

\section{Preparação do material coletado na PesQuisa de Campo}

Mesmo que esse texto seja um relato de uma pesquisa de campo, achamos por bem escrever sobre a etapa posterior à coleta dos dados, pois essa é uma fase muito importante para a qualidade da pesquisa como um todo.

Depois da etapa de coleta dos depoimentos feitos na pesquisa de campo em Itacaré, sempre em locais próximos ao rio das Contas, passamos para a etapa de transcrição, o que não foi uma tarefa fácil, pois demandou muito tempo, atenção e cuidado para não deixar nenhum detalhe de fora.

A principal preocupação que tivemos foi com o registro/transferência dos depoimentos (falas) para um arquivo de computador, sem nos preocuparmos com a pontuação e ortografia corretas. Também não demos atenção às palavras repetidas, aos vícios de linguagem, entre outros aspectos.

Depois disso fizemos a chamada "limpeza do texto", que se destina a dar forma adequada ao texto, ou seja, pontuação e ortografia corretas. Observamos ainda, que a transcrição foi fiel à gravação, e que essa "limpeza" não alterou os depoimentos das pessoas.

Quanto às observações feitas em Taboquinhas, na cidade de Itacaré e ao longo do rio das Contas, digitamos o que havíamos escrito em um papel, 
no momento e após a observação, para ficar disponível para a escrita da pesquisa. Com relação às fotografias tiradas na pesquisa de campo, foram transferidas da câmara fotográfica para um arquivo do computador, para posteriormente serem usadas como dados da pesquisa.

\section{Conclusão}

O método da história oral e as técnicas adotadas para a pesquisa de campo foram válidos na medida em que corresponderam ao alcance dos objetivos da pesquisa, dentro de uma abordagem da Geografia Humanista, do tipo qualitativa.

Ao mesmo tempo foi muito importante aplicarmos, pessoalmente, os instrumentos de coleta das informações, ou seja, colher os depoimentos, tirar fotografias e, ainda, observar geograficamente o lugar, para conhecermos, convivermos e interagirmos com os sujeitos da pesquisa, enfim, vivenciarmos diretamente os locais da pesquisa.

Essa convivência trouxe uma importante contribuição para a qualidade das informações coletadas, além de uma grande experiência vivida em uma pesquisa de campo, na perspectiva da Geografia Humanista.

Enfim, concluímos que esse tipo de pesquisa de campo pode ser realizado com alunos do ensino fundamental e médio, pois vivenciar e experienciar os lugares, as paisagens da sua realidade e o cotidiano com certeza lhes proporcionará um grande aprendizado geográfico. 


\section{REFERÊNCIAS}

ALBERTI, V. Manual de história oral. 2. ed. Rio de Janeiro: Editora FGV, 2004.

BOGDAN, R.; BIKLEN, S. Investigação qualitativa em educação. Porto, Portugal: Porto Editora, 1994.

BOURDIEU, P. A ilusão biográfica. In: AMADO, J.; FERREIRA, M. de M. Usos e abusos da história oral. Rio de Janeiro: Editora FGV, 1996.

O poder simbólico. Tradução de Fernando Tomaz.

2. ed. Rio de Janeiro: Bertrand, 1998.

A miséria do mundo. Tradução de Mateus S. Soares. 3. ed. Petrópolis, RJ: Vozes, 1999.

CHIAPETTI, R. J. N. Na beleza do lugar, o rio das Contas indo... ao mar. 2009. 216 f. Tese (Doutorado em Geografia)Instituto de Geociências e Ciências Exatas, Universidade Estadual Paulista Júlio de Mesquita Filho, Rio Claro, 2009.

Pesquisa de campo qualitativa: uma vivência em Geografia Humanista. Geotextos, Salvador, v. 6, n. 2, p. 139-162, dez. 2010.

; CHIAPETTI, J. A água e os rios: imagens e imaginário da natureza. Geograficidade, Niterói, v. 1, n. 1, p. 71-9o, inverno 2011.

CHIZOTTI, A. Pesquisa em Ciências Humanas e Sociais. São Paulo: Cortez, 1991.

DUARTE, R. Pesquisa qualitativa: reflexões sobre trabalho de campo. Cadernos de Pesquisa, São Paulo, n. 115, p. 139-154, mar. 2002. 
GRATÃO, L. H. B. A poética d' "Rio" - Araguaia! De cheias... e... vazantes... (à) luz da imaginação! 2001. $354 \mathrm{f}$. Tese. (Doutorado em Ciências: Geografia Física)- Faculdade de Filosofia, Letras e Ciências Humanas, Universidade de São Paulo, São Paulo, 2002.

HOLZER, W. A Geografia Humanista anglo-saxônica - de suas origens aos anos 9o. Revista Brasileira de Geografia, Rio de Janeiro, v. 5, n. 1-4, p. 109-146, jan./dez 1993.

. Uma discussão fenomenológica sobre os conceitos de paisagem e lugar, território e meio ambiente. Revista Território, Rio de Janeiro, n. 3, p. 77-85, jul.-dez. 1997.

LAVILLE, C.; DIONNE, J. A construção do saber: manual de metodologia da pesquisa em Ciências Humanas. Porto Alegre: Artes Médicas Sul; Belo Horizonte: Editora da UFMG, 1999 .

MEIHY, J. C. S. Manual de história oral. São Paulo: Loyola, 2000.

MELLO, J. B. F. Geografia Humanística: a perspectiva da experiência vivida e uma crítica radical ao positivismo. Revista Brasileira de Geografia, Rio de Janeiro, v. 52, n. 4, p. 91-115, 1990.

MINAYO, M. C. de S. (org.). Pesquisa social: teoria, método e criatividade. 17. ed. Petrópolis, RJ: Vozes, 1994.

SUERTEGARAY, D. M. A. Geografia e trabalho de campo. In: __ Geografia Física, Geomorfologia: uma (re)leitura. Ijuí: Editora da UNIJUI, 2002.

TEIXEIRA, E. As três metodologias: acadêmica, da ciência e da pesquisa. 2. ed. Petrópolis: Vozes, 2006.

THOMPSON, P. A voz do passado: historia oral. Rio de Janeiro: Paz e Terra, 1992. 
TUAN, Y. Espaço e lugar: a perspectiva da experiência. São Paulo: Difel, 1983.

WHYTE, A. V. T. Guidelines for fields studies in environmental perception. Paris: UNESCO, 1977. (MAB Technical Notes 5). 


\section{PARA ALÉM DO \\ "DESCOBRIMENTO" \\ DO BRASIL: notas sobre a \\ formação territorial do sul \\ da Bahia para o ensino da \\ Geografia $^{1}$}

\section{Jorge Chiapetti}

\section{Introdução}

Este artigo discute a formação territorial do sul da Bahia e seu vínculo inexorável com a produção e comercialização de cacau. Como parte da discussão desenvolvida em tese de doutorado em Geografia, buscou-se, nesse momento, direcioná-la a um público mais amplo, por considerarmos que é função da universidade socializar os resultados da pesquisa desenvolvida no seu interior. Dessa forma, acreditando que essa discussão é importante para a compreensão do processo de constituição da Região Cacaueira, resolvemos integrá-la no bojo desse trabalho voltado para o ensino de Geografia - e áreas afins - na universidade, como, também, no ensino médio, pois consideramos que os professores da educação básica devem estar constantemente ampliando suas leituras e reflexões sobre conteúdos com os quais trabalharão com seus alunos em sala de aula.

Inicialmente, recorremos ao processo histórico de formação do território brasileiro no âmbito do capitalismo comercial, a fim de compreender a sua gênese enquanto um espaço derivado da economia mundial, que se amplia a partir do século XVI, com a hegemonia europeia sobre os territórios conquistados e explorados a partir de então.

Em seguida, localizamos o tempo/espaço de formação da região cacaueira, suas atividades produtivas, os agentes sociais endógenos e exógenos e as especificidades da interrelação sociedade/natureza que produziram a referida região. A discussão é toda embasada em autores clássicos e

O autor agradece às contribuições do Prof. Dr. Gilmar Alves Trindade. 
contemporâneos que estudaram essa região ou que produziram análises em torno das contradições relacionadas à inserção dos processos produtivos locais/regionais no âmbito do capitalismo mundial.

\section{ANTECEDENTES HISTÓRICOS DA FORMAÇÃO DO TERRITÓRIO BRASI- LEIRO COMO COLÔNIA DE PRODUÇÃO}

A formação do território brasileiro é um processo derivado da expansão do sistema socioeconômico da Europa, a partir do século XV, momento do processo em que os sistemas de ações, marcadamente ritmadas pelo modo capitalista mercantil, buscavam ampliar os horizontes de exploração de mercadorias, as quais seriam comercializadas vantajosamente no mercado europeu.

No movimento de conquistas e partilha das novas terras entre as economias hegemônicas da Europa, o domínio português sobre o Brasil impôs o uso do território como um recurso na acumulação primitiva em escala mundial. A acumulação primitiva é um conceito elaborado por Karl Marx para explicar o enriquecimento das nações e de indivíduos na origem do sistema capitalista. Para Marx (1894, p. 370):

A descoberta das terras do ouro e da prata, na América, o extermínio, a escravização e o enfurnamento da população nativa nas minas, o começo da conquista e pilhagem das Índias Orientais, a transformação da África em cercado para a caça comercial às peles negras marcam a aurora da era de produção capitalista. Esses processos idílicos são momentos fundamentais da acumulação primitiva. De imediato seguem as guerras comerciais das nações europeias, tendo o mundo por palco. [...]. Os diferentes momentos da acumulação primitiva repartem-se então, mais ou menos em ordem cronológica, a saber, pela Espanha, Portugal, Holanda, França e Inglaterra. [...]. Todos, porém, utilizaram o poder do Estado, a violência concentrada e organizada da sociedade, para ativar artificialmente o processo de transformação do modo feudal de produção em capitalista e para abreviar a transição. A violência é a parteira de toda a velha sociedade que está prenhe de uma nova. Ela mesma é uma potência econômica.

2 Usaremos, neste texto, o termo colônia de produção, similar à expressão colônia de exploração, que geralmente aparece nos livros didáticos do ensino fundamental e do médio. 
Porém, antes da exploração propriamente dita, houve uma disputa política na partilha das novas terras da América, acirrando ainda mais a rivalidade entre Portugal e Espanha iniciada com o Tratado de Toledo (1480), através do qual Portugal dava à Espanha as Ilhas Canárias, localizadas na Costa Africana, em troca do monopólio do comércio e navegação do litoral africano, ao sul da linha do Equador.

Com a necessidade de buscar novas fontes de recursos naturais para o fortalecimento da economia, o Tratado de Tordesilhas, em 1494, veio estabelecer as regras de exploração das terras do Brasil dando início a um novo ciclo econômico para Portugal.

A exploração comercial de um território virgem se deu em proveito de objetivos completamente estranhos à sua população, e em que essa população não figura senão como elemento propulsor destinado a mantê-la em funcionamento (PRADO JÚNIOR, 1974, p. 102),

para a produção de excedentes, os quais se transformaram em lucros no comércio internacional, sendo apropriado, exclusivamente, pela burguesia metropolitana.

Não bastasse o uso privilegiado - a exploração do território brasileiro como recurso em benefício da expansão do mercado europeu - a ordem social se formava sob o comando de uma monarquia absolutista que, "de mera reunião de cortesãos e protegidos, faz-se órgão de domínio" (FAORO, 2000, p. 12) e do exercício do poder, e tinha como benefício a exploração de todas as "possibilidades econômicas" do território. Para Ribeiro (1998), a apropriação das possibilidades econômicas pelos grupos dominantes é um processo histórico e se inicia no processo civilizatório que teve origem em dois processos distintos: as cidades-estado e os estados rurais artesanais, onde existia um governo central permanente que exercia o domínio da sociedade. Esse poder sempre foi exercido por uma minoria de homens de prestígio que monopoliza o uso legítimo da força para perpetuar e alargar seus privilégios; e assim:

Manter os interesses investidos destinados a assegurar às camadas privilegiadas o gozo tranquilo e a frutificação de suas regalias. [...]. Uma vez instituídos, os Estados tendem a uma regulamentação cada vez mais restritiva das atividades sociais, em termos de preservação dos interesses dos grupos dominantes. Assim, a defesa dos interesses dos grupos dominantes acaba 
atuando como incentivadora do desenvolvimento econômico dos lugares como uma marcha do progresso, mas sempre o problema é o mesmo, isto é, o benefício desse progresso não se estende à sociedade toda, ficando concentrado nas mãos das classes dominantes (RIBEIRO, 1998, p. 101-115).

O direito exclusivo de exploração e comercialização das mercadorias se apresentava vantajoso para o capital comercial europeu, e a exploração da colônia brasileira foi posta em marcha,

enquanto outras colônias se estruturavam como colônias de povoamento, portanto, na retaguarda da expansão mercantil [...], o Brasil exemplarmente, nascia para o sistema na vanguarda, isto é, como lugar de produção (OLIVEIRA, 1998, p. 206).

A diferença entre colônias de povoamento e de produção, ou exploração, pode ser caracterizada por comparação entre os processos de colonização, como se deram no Brasil e nos EUA. Em uma comparação histórica, os EUA e o Brasil partiram de um mesmo ponto, sendo que ambos eram dependentes de suas metrópoles e foram criados no ciclo expansivo do capitalismo mercantil, mas com dinâmicas diferentes. Os EUA foram colônia de povoamento que teve dificuldades no seu início; já o Brasil foi uma colônia de exploração, tendo grande êxito inicial. Desta dinâmica inicial provêm as diferenças: o fracasso inicial dos EUA o ligará como uma extensão da economia da Europa; já com relação ao Brasil, o êxito é sinal de que a colônia é uma projeção da economia europeia, mas com uma ligação apenas como fonte de recursos, o que lhe atribui - no caso de esgotar tais recursos - constantes períodos de êxitos e fracassos (OLIVEIRA, 2003b).

Como o único objetivo era a exploração, os primeiros povoados começaram sem nenhum planejamento, formando-se aleatoriamente com ruas tortuosas, becos e vielas, numa clara demonstração de que, no período colonial, o interesse em relação ao território brasileiro era condicionado por fatores puramente econômicos, como a busca de fortuna rápida, "que devia ser gozada mais tarde em Portugal, em quintas e castelos" (BARROS, 2004, p. 95).

A exploração do território brasileiro se efetivou, e a demanda crescente de produtos como madeira, metais, açúcar e café avivaram a cobiça dos europeus. Então: 
Novas terras, novos bens abrem-se à cobiça dos invasores. Revive-se o ímpeto predatório e mercantil que leva à aceleração econômica da matriz em termos de uma acumulação de riqueza em geral rápida e grávida de consequências para o sistema de trocas internacional. Se o aumento na circulação de mercadorias se traduz em progresso, não resta dúvida de que a colonização do Novo Mundo atuou como um agente modernizador da rede comercial europeia durante os séculos XVI, XVII e XVIII (BOSI, 1992, p. 20, grifo do autor).

Como consequência, o processo de expansão do sistema mercantil mundial deu origem às primeiras estruturas de atividades econômicas no território, como um sistema de exploração econômica e social baseado na relação do trabalho escravo e numa estrutura concentradora de terras. Desse modo, a formação territorial do Brasil se processou sob o signo da fratura social - de um lado, os europeus, que formavam a classe de latifundiários, e do outro, os escravos, como força de trabalho.

O termo fratura social significa o distanciamento do poder aquisitivo entre os estratos superiores e inferiores na sociedade. Sampaio (2003, p. 7) utiliza o conceito de "Abismo social" para essa diferenciação entre classe alta, com grande propensão ao consumo, devido à concentração da renda, e classe baixa, com precárias condições de vida e com pouca propensão ao consumo.

De acordo com Bosi (1992), os sistemas de ação colonizadora no Brasil tomaram uma forma peculiar dominante e exploratória que condicionou e marcou profundamente a formação territorial brasileira, com destaque para: 1) o predomínio de latifundiários vinculados a grupos mercantis europeus, principalmente de traficantes de escravos, os quais se constituíram em força de trabalho e, posteriormente, numa população que se formou marginalmente ao sistema econômico e social; 2) uma estrutura política local amarrada aos interesses dos proprietários de terra, os quais eram subalternos às instâncias superiores (juntas da Fazenda e da Justiça compostas por funcionários reais, como provedores, ouvidores, procuradores, intendentes etc.), comandados pelas Leis do Reino de Portugal, constituindo-se num poder absolutista; 3 ) a dependência e obediência total ao sistema religioso de Portugal; 4) e o controle sobre o acesso à alfabetização, o que resultou num divisor ou num "abismo social" entre os alfabetizados (cultura oficial) e os analfabetos (cultura popular), caracterizando-a, assim, como uma cultura arcaica, atrasada, que vivia na fronteira da cultura europeia. 
Estabeleceu-se, então, um circuito fechado de controle do processo produtivo e social, cujas normas rígidas comandadas pela metrópole garantiam a exploração do território brasileiro e mantinham o fluxo de mercadorias para o mercado europeu. Para Furtado (1989, p. 15), o território brasileiro: "Não é fruto nem de conquistas e nem de um projeto de colonização", mas de uma ocupação que não coube o direito de escolha no processo de formação territorial. Portanto:

Desde seus primórdios, tudo se apresenta como definitivo, com os traços básicos que persistiriam por séculos. Os que chegam trazem consigo meios necessários para por em marcha uma empresa que já nasce próspera. [...]. Um povo de comerciantes criava a primeira organização produtiva agrícola do hemisfério ocidental vinculada ao mercado europeu. [...]. Estava lançada uma operação transcontinental de grande envergadura com o objetivo de criar um fluxo de exportação para um mercado situado a milhares de quilômetros. Dessa forma os critérios econômicos se sobrepõem a tudo. Poucas vezes na história humana uma formação social terá sido condicionada em sua gênese de forma tão cabal por fatores econômicos (FURTADO, 1989, p. 15).

Os mecanismos de exploração e controle e sua inserção no sistema econômico mundial que se seguiu contribuíram para um processo de formação de uma sociedade e um território pouco integrados. A história da formação do território brasileiro é, assim, uma história de fragmentações, o que não é característica de apenas uma fase de nossa formação, a qual tenderia a se corrigir com o tempo, como ocorreu em países de colonização de povoamento - que, mesmo antes da Revolução Industrial inglesa, mostravam-se mais integrados e com maior capacidade de promover o desenvolvimento econômico interno - pois, como um processo da expansão do sistema político-econômico e religioso-cultural da Europa,

A natureza colonial da economia brasileira se orientou essencialmente para o exterior; e é de lá, portanto, que provêm seus principais e fundamentais estímulos (PRADO JUNIOR, 1974, p. 334).

A exploração mercantilista atribuiu importância para várias regiões do território brasileiro em diversos períodos históricos, como a cana de açúcar para Salvador e Recife, o café para São Paulo, o ouro para Minas Gerais, a borracha para Belém e Manaus. Como "Uma sociedade existe 
sempre sob um invólucro histórico determinado" (SANTOS, 1979, p. 12), na região Sul da Bahia se seguiu o mesmo processo de ocupação do Brasil, como um lugar de exploração mercantilista, um lugar, um território que se formou para servir de condição para o êxito da expansão econômica europeia. Um modelo que persiste, que teima em permanecer nas relações, nos pensamentos e nas atitudes das elites políticas e econômicas.

\section{A FormaÇão da REgiño Sul da Bahia COMO ESPAÇO DERIVAdo DA ECONOMIA MUNDIAL}

$\mathrm{Na}$ capitania de Ilhéus, como em todo o litoral brasileiro, a natureza ia cedendo lugar à produção de cana de açúcar e, em 1564, Ilhéus contava com oito engenhos de açúcar em plena produção (SCHWARTZ, 1988). Ao longo dos séculos XVI e XVII, atraídos pela grande lucratividade, os beneficiários da coroa portuguesa realizaram aqui investimentos na produção de açúcar, tornaram Ilhéus o centro dinâmico da exploração na capitania.

Depois da metade do século XVII, a atividade açucareira da colônia brasileira, como um todo, entrou em crise devido à mudança da estrutura de poder nos países europeus, resultado da maior concorrência no mercado açucareiro mundial (OLIVEIRA, 2003a). Para Furtado (1977), a crise da produção de açúcar na colônia brasileira foi também agravada pelo aumento do preço dos escravos e pelo deslocamento de mão de obra especializada para a exploração do ouro.

Por causa da sucessão dessas crises na produção de cana de açúcar, a capitania de Ilhéus chega, em 1724, somente com um engenho em funcionamento (SCHWARTZ, 1988), e se a atividade açucareira não se apresentava mais vantajosa para a metrópole, a continuidade da sua exploração dependia de outra atividade rentável para manter o fluxo de mercadorias e os lucros para a burguesia metropolitana.

Assim, a opção da metrópole para a continuidade da exploração da Capitania de Ilhéus foi o cultivo do cacau (Theobroma cacao) que, sendo originário da América Central e da América do Sul, encontrou, na Mata Atlântica do sul da Bahia, as condições favoráveis e semelhantes ao seu local de origem, com solos apropriados, um clima quente e úmido e de chuvas abundantes (FIGURA 1). 
FIGURA 1 - Cacaueiro (Theobroma cacao) em produção, Ilhéus, Bahia

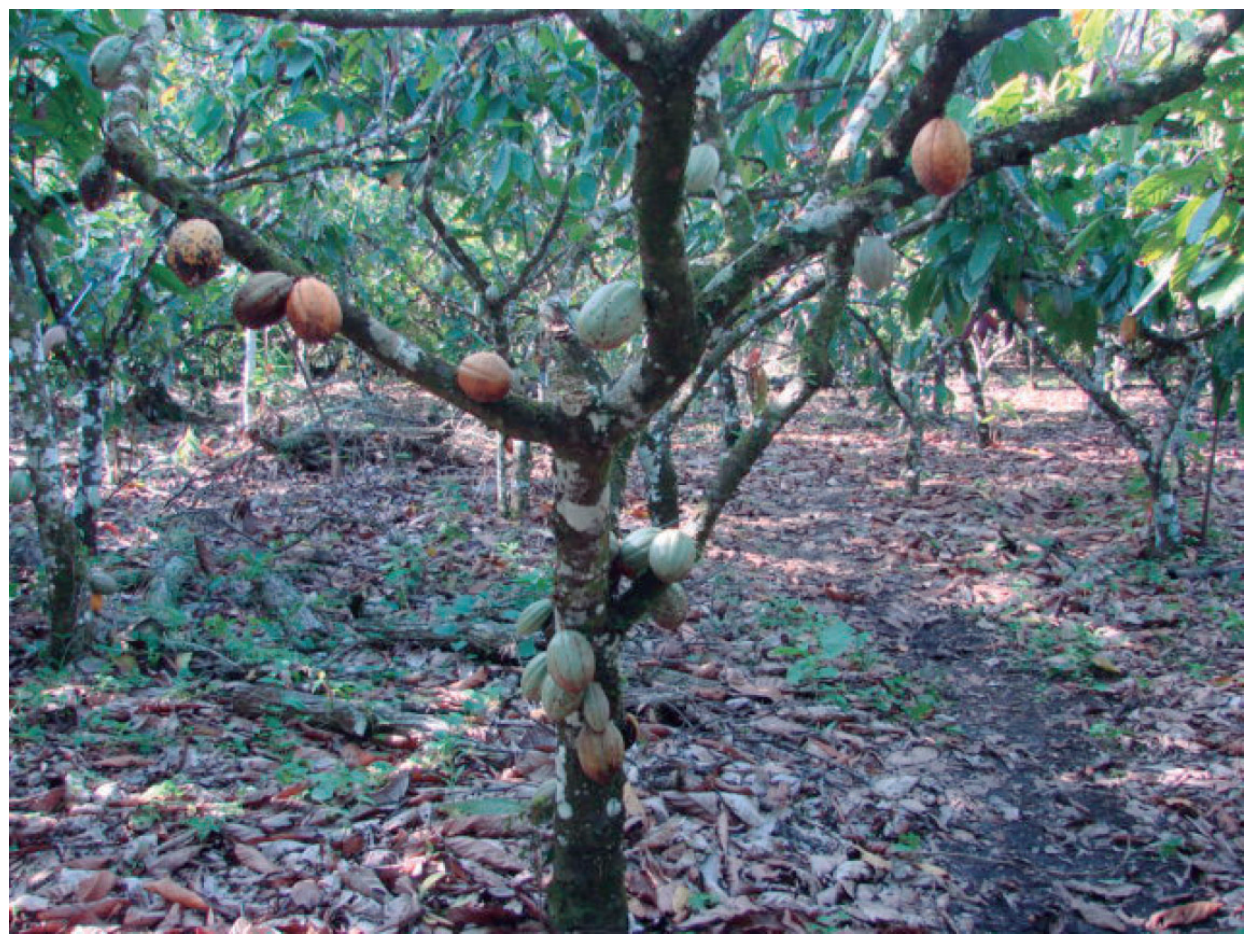

Fonte: Jorge Chiapetti, 2010.

As primeiras amêndoas de cacau foram trazidas do Pará por Luiz Frederico Warneaux e entregues a Antônio Dias Ribeiro, que as plantou, no ano de 1746, na fazenda Cubículo, localizada às margens do rio Pardo, no município de Canavieiras, e somente seis anos depois chegou a Ilhéus. Existem outras datas para o início dos plantios de cacau em Ilhéus, que são citadas por vários autores, como 1755 a 1760 e 1780. Embora existam registros de cultivo milenar pelos povos astecas e incas e os índios da Amazônia utilizassem as amêndoas, para fazer vinho através de sua fermentação, bem antes da chegada de Cabral ao Brasil, a data oficial para o cultivo do cacau em solo brasileiro é 1679, quando a Carta Régia dessa época autorizava que os colonos do Pará plantassem as amêndoas em suas terras (VINHÁES, 2001). No início, o cultivo do cacau não teve grande êxito, mas a partir do ano de 1783 , já era considerada uma cultura importante no sul da Bahia.

Inicialmente, a atividade de plantio do cacau se deu paralelamente à atividade de cultivo de cana de açúcar, e outras culturas, como o arroz. Mas, ao final do século XVIII, com o aumento da demanda no mercado internacional, a produção de amêndoas de cacau passou a ser considerada uma atividade agrícola importante para a colônia portuguesa. 
Analisando os eventos históricos que contribuíram para o processo de formação de uma atividade econômica, o cacau teve expressão no mercado a partir do seu conhecimento pelos europeus, primeiramente pelos espanhóis que, por muitos anos, detinham os segredos de seu processamento. O seu uso foi difundido na Espanha, depois na França e se espalhou por toda a Europa. Em 1657 surgiu a primeira casa de chocolate em Londres. $\mathrm{Na}$ Holanda, o chocolate se tornou bebida popular em 166o. Em 1728 foram instaladas fábricas de chocolate em Bristol, na Inglaterra; em 1756 em Steinhunde, na Alemanha, e nos EUA. Na França, foi instalada a primeira fábrica de chocolate, em 1776 (BONDAR, 1938). Em 1828, o holandês Coenraad Johannes Van Houten inventou o método para extrair manteiga de cacau, originando o cacau em pó. Em 1875, formulado pelo industrial suíço Henri Nestlé e o inventor suíço (fabricante de chocolate) Daniel Peter, surgiu, na Suíça, o chocolate ao leite, que popularizou o seu consumo (COSTA, 2008). Todos esses eventos contribuíram para o aumento da demanda de amêndoas de cacau nos EUA e na Europa e, consequentemente, estimularam a produção de amêndoas de cacau no sul da Bahia.

Em 1783,

os administradores provisórios da Bahia não escondem seu entusiasmo pelo desenvolvimento da cultura do cacau - do qual já havia mais de 400 mil pés - e traziam progresso para a região (SANTOS, 1957, p. 44).

Para Barbosa (1994), foi somente em 1822 que a atividade cacaueira teve um novo impulso com a chegada de imigrantes alemães que se estabeleceram numa sesmaria localizada à margem esquerda do rio Cachoeira, em Ilhéus; adquirida da coroa portuguesa por Pedro Weill, em 1818, ali se instalaram 161 colonos alemães em 1822. Em 1875, o número de colonos alemães, em Ilhéus, passou para 400 (ADONIAS FILHO, 1978).

Quanto à imigração europeia, é importante ressaltar que esses estrangeiros não chegaram ao sul da Bahia como consequência da substituição do braço escravo, como aconteceu nas fazendas paulistas e fluminenses de café, mas sim vieram em busca de fazer fortuna. O interesse desses imigrantes, na atividade cacaueira, pode ser atribuído à herança da racionalidade econômica adquirida na expansão do sistema político e econômico na Europa. Mas, vale ressaltar que o fracasso comercial inicial das colônias de povoamento da Inglaterra e França e a desarticulação da agricultura europeia, como resultado das guerras napoleônicas, haviam proporcionado oportunidades e experiência de imigração do povo europeu. 
Não se pode negar a contribuição dos imigrantes, no entanto, a expansão do cacaueiro ocorreu devido a dois eventos predominantes: a decadência da atividade canavieira e o aumento da demanda e do preço das amêndoas de cacau, no mercado internacional em consequência da difusão das técnicas de processamento do cacau em chocolate e da criação das casas de chocolate, o que avivou a cobiça dos imigrantes. No início do século XIX, foi grande a participação estrangeira na exploração e no desbravamento no sul da Bahia, com alemães, suíços, belgas, franceses, poloneses e austríacos.

A verdade é que, dentre as experiências de colonização europeia no sul da Bahia, mesmo não relacionadas com o cacau, foi a de Ilhéus a única que realmente progrediu (ADONIAS FILHO, 1978, p. 70).

A atividade cacaueira se expandiu, então, por toda a região e, já em 1825, Ilhéus exportava $26.805 \mathrm{~kg}$ (447 sacos) para a Inglaterra, obtendo ótima rentabilidade" (BONDAR, 1938, p. 27).

Em 1867, os cacauicultores participaram da Exposição Universal de Viena e o cacau brasileiro recebeu menção honrosa, consolidando-se no mercado mundial (ADONIAS FILHO, 1978).

A cada necessidade imposta pelo sistema econômico europeu em vigor, a resposta foi encontrada, nos países subdesenvolvidos, pela criação de uma nova região ou pela transformação das regiões preexistentes (SANTOS; SILVEIRA, 2005). A FIGURA 2 demonstra, resumidamente, numa linha do tempo, os principais eventos que ocorreram na Europa e que contribuíram para a formação da atividade cacaueira no sul da Bahia.

Com o aumento das exportações, a atividade cacaueira se afirmou como base da economia regional e, assim, a dinâmica do mercado internacional, com suas variações de preços e demanda, passou a determinar também a dinâmica e o movimento populacional na região, dando origem aos primeiros núcleos urbanos da região cacaueira e à instalação de um sistema de engenharia como um porto, estradas de ferro e rodovias. Contudo, havia uma desconexão com outras regiões, todos os sistemas de engenharia estavam orientados para favorecer o fluxo de mercadorias a fim de satisfazer as necessidades além dos mares. 
FIGURA 2 - Linha do tempo dos principais eventos da atividade cacaueira na Europa e no Brasil (1650 a 1920)

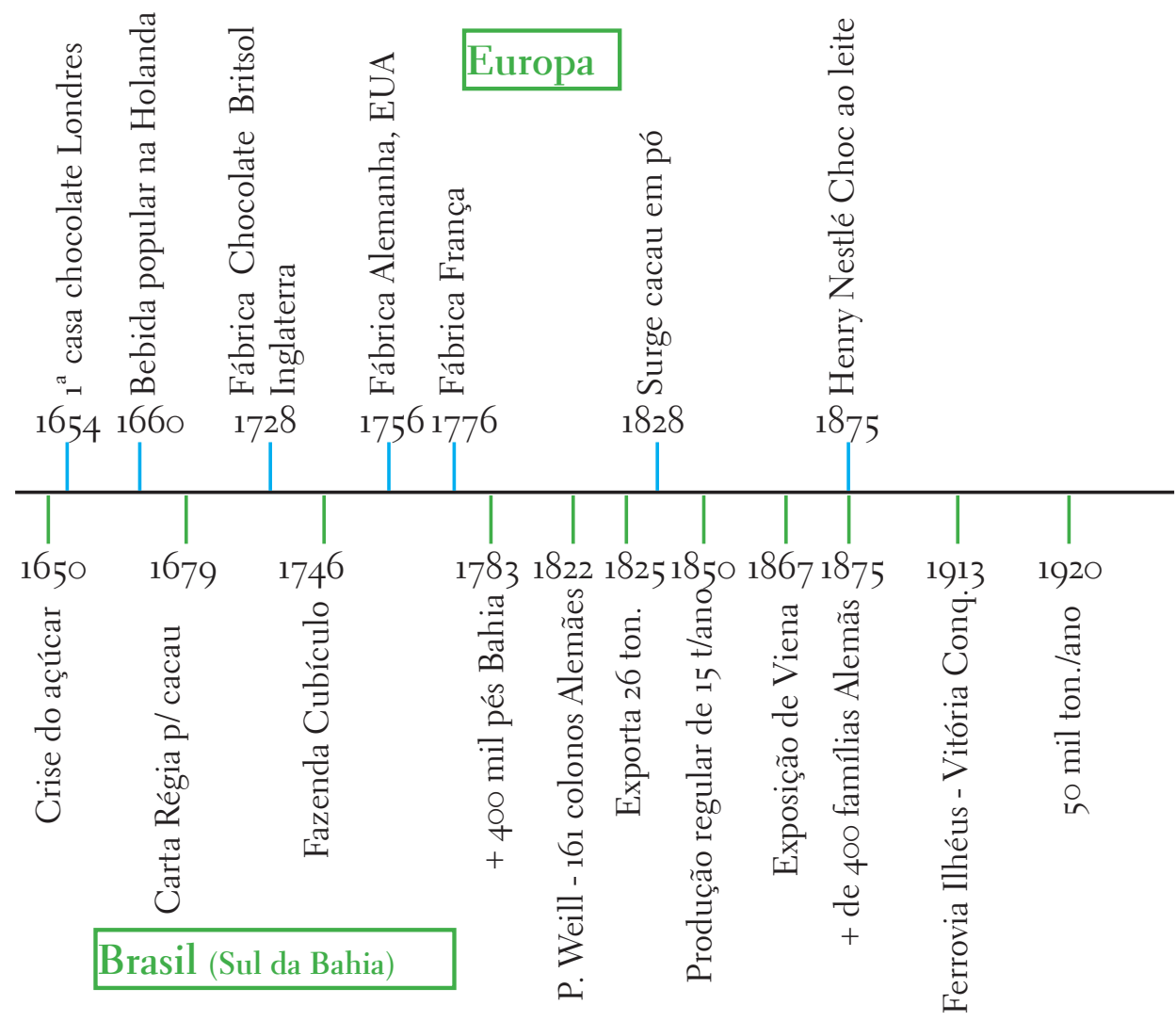

Fonte:Chiapetti, 2009.

Nota: Elaboração de Jorge Chiapetti.

Assim é que o processo de formação da região Sul da Bahia se caracterizou pela inserção na economia mundial como um "espaço derivado", ou seja, a formação territorial teve como vetor principal uma ordem forânea, que se sobrepunha à ordem local, o que lhe tem outorgado constantes e contraditórios períodos de crescimento econômico e crises. "Espaço derivado" é um conceito criado pelo geógrafo Milton Santos a partir das leituras de Maximilien Sorre, no livro L'Homme sur la terre (1961). Santos (1978, p. 104) escreveu:

\footnotetext{
3 Tomamos para o termo crise o conceito de Santos (2005), isto é, momentos em que a ordem estabelecida entre as variáveis, mediante uma organização, é comprometida e introduz um princípio de desordem.
} 
É a Maximilien Sorre que se deve a denominação paisagens derivadas. Desde que ele a adotou para as regiões dos países subdesenvolvidos, tentou mostrar as relações entre a história dos países industriais e a dos países subdesenvolvidos.

Na releitura desse conceito, Santos (1978) fez uma diferenciação na mudança da palavra paisagem para espaço, já que ele estava se referindo não apenas às formas derivadas, mas ao espaço como instância, isto é, as funções, os processos e as estruturas, pois,

a cada necessidade imposta pelo sistema em vigor, a resposta foi encontrada, nos países subdesenvolvidos, pela criação de uma nova região ou a transformação das regiões preexistentes. É o que chamamos de espaço derivado, cujos princípios de organização devem muito mais a uma vontade longínqua do que aos impulsos ou organizações simplesmente locais. Pelo fato de serem derivados, estes espaços se organizam e se reorganizam em relação a interesses distantes: sua organização é função de necessidades exógenas e depende de parâmetros importados, tomados de empréstimos aos sistemas representativos desses interesses distantes (SANTOS, 1978, p. 104-105, grifo do autor).

Todos os períodos de transformação da região cacaueira aparecem tanto na vocação racional das ações historicizadas e geograficizadas, como na vocação originalmente técnica dos objetos que aí vão se instalando funcionalmente. "A ação é tanto mais eficaz quando os objetos são mais adequados" (SANTOS, 2006, p. 94). Desde a ocupação portuguesa da região, todo um sistema (objetos e ações indissociáveis) estrutura um meio geográfico favorável ao fluxo de exportação de matéria-prima, para abastecer mercados distantes, os quais determinaram a formação da região como um espaço derivado.

\section{O SISTEMA DE PRODUÇÃo DO CACAU NO SUl DA BAHIA: GÊNESE DA FORMAÇÃO REGIONAL}

As condições fisiográficas favoráveis e um mercado externo em expansão despertaram o interesse dos agricultores para a exploração da atividade cacaueira no sul da Bahia; e a Mata Atlântica começou a receber os primeiros cultivos do cacaueiro sob a forma de cabruca (FIGURA 3 ). O cacau de cabruca tem origem nos primeiros plantios que, grosso modo, cabrucavam (retiravam as árvores mais finas da mata e deixavam as mais altas para sombrear) para plantar as amêndoas de cacau. 
FIGURA 3 - Aspecto do cultivo de cacau em associação com a Mata Atlântica no sistema cabruca, Ilhéus, Bahia

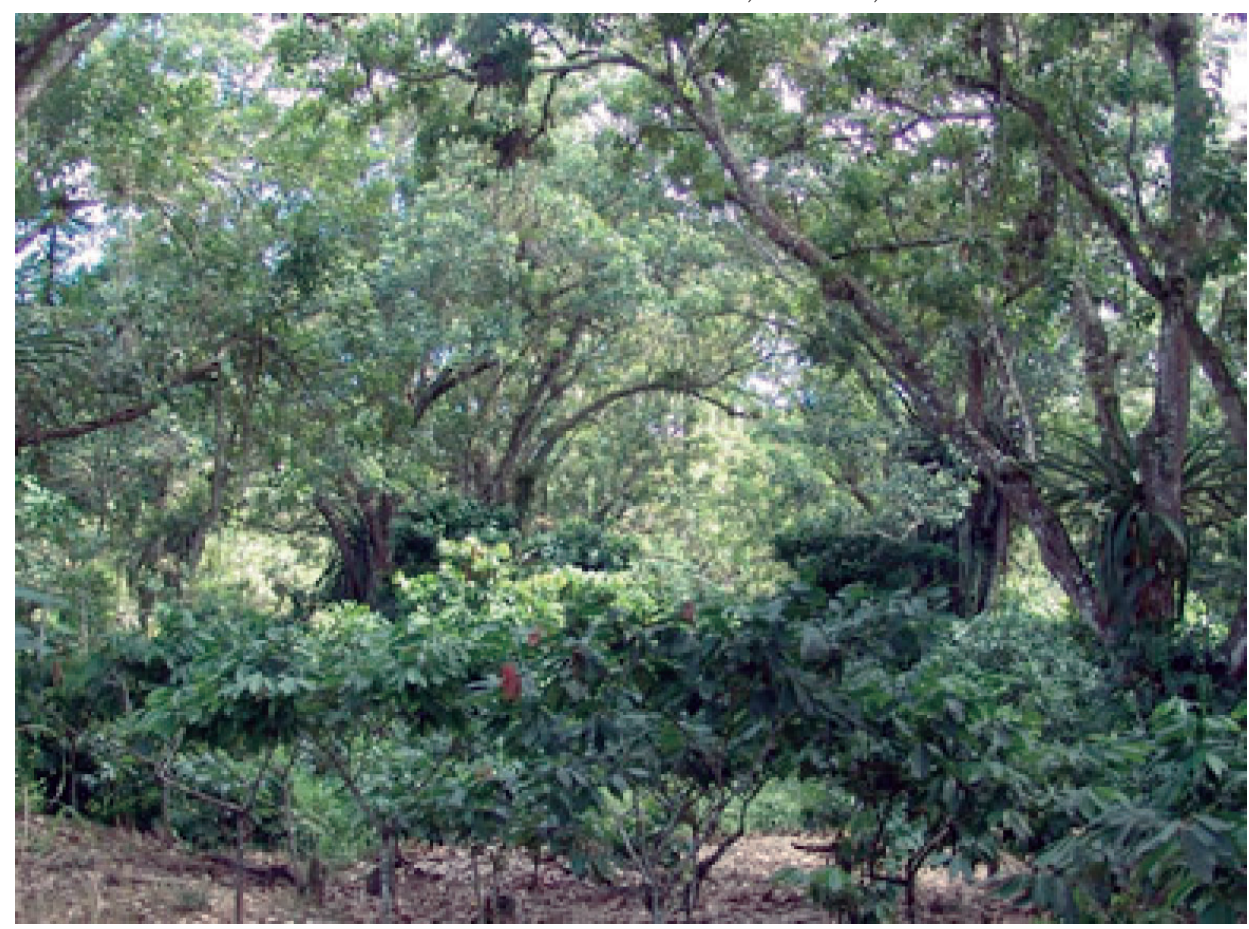

Fonte: Jorge Chiapetti, 2014.

No momento em que a atividade cacaueira ainda se dava em ritmo lento e descontínuo, imposto pelas variáveis naturais, as dificuldades eram superadas pelos estímulos e expectativas de acumulação de capital. Nesse momento, em que a natureza e as expectativas de acumulação eram as variáveis-chave da dinâmica local, a formação territorial era a

base de uma produção fundada na criação de um meio técnico muito mais dependente do trabalho direto e concreto do homem do que da incorporação de capital à natureza (SANTOS; SILVEIRA, 2005, p. 35).

A partir de meados do século XIX, a atividade cacaueira passou a produzir, em média, 15 toneladas por ano, quantidade essa que possibilitou estabelecer um fluxo de exportação contínuo e ao ritmo crescente das cotações e da demanda internacional, alcançando uma produção média de 50 mil toneladas/ano, em 1920. 
Com o crescimento da produção de amêndoas (FIGURA 4), a atividade cacaueira se tornou o suporte econômico regional, impondo um ritmo próprio à formação territorial, o que a caracterizou como região cacaueira da Bahia.

FIGURA 4 - Produção de amêndoas de cacau na Bahia (1918-1930)

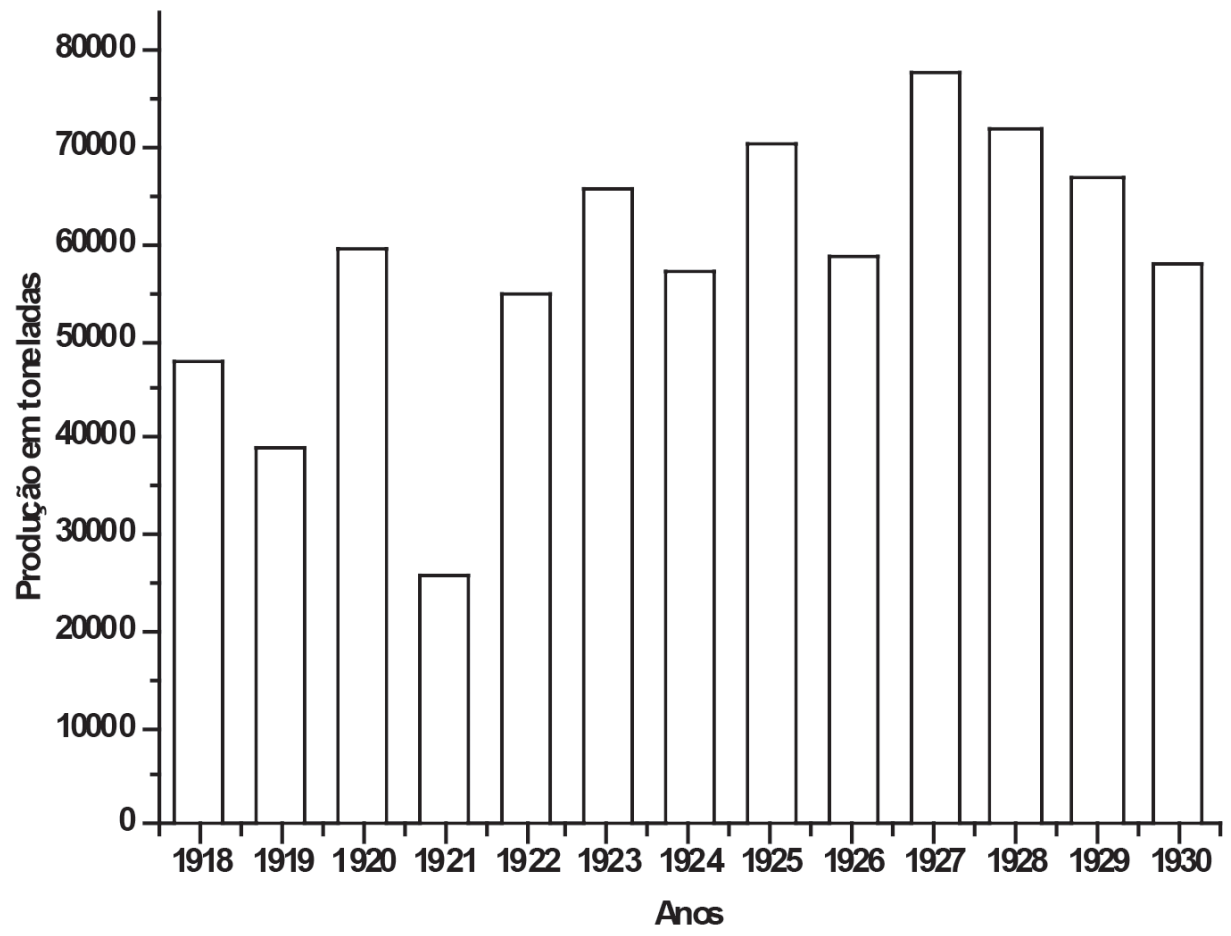

Fonte: Santos (1957, p. 112).

Nota: Elaboração de Jorge Chiapetti, 2010.

O romancista Jorge Amado, que nasceu em Itabuna e viveu por muitos anos em Ilhéus, produziu importantes obras que narram a ordenação desse território e as históricas lutas pela posse da terra e pelo poder. Os livros Cacau (1933) e Terras do Sem Fim (1943) se referem ao processo de formação das cidades cacaueiras; São Jorge dos Ilhéus (1944) trata do poderio urbano dos coronéis do cacau, e Tocaia Grande (1984) aborda o processo de conquista e desbravamento das terras da região.

A região cacaueira da Bahia, de acordo com a divisão do Instituto Brasileiro de Geografia e Estatística (IBGE) em mesorregiões, está localizada na Mesorregião Sul Baiano ou Região Sul da Bahia, subdividida em 
três microrregiões: Baixo Sul, Ilhéus-Itabuna e Porto Seguro, num total de 70 municípios. A denominação região cacaueira, hoje em dia, remete mais ao passado recente e ao conteúdo simbólico que historicamente definiu esta região do que à relevância da atividade cacaueira.

Em função da atual crise da produção de cacau, da busca de novas alternativas econômicas para a região, a partir de 1990, uma nova divisão regional da Bahia, elaborada pelo IBGE passou a designar a antiga região cacaueira da Bahia de Microrregião Geográfica Ilhéus-Itabuna, com 41 municípios (FIGURA 5). Tal regionalização se baseou não mais apenas na produção do cacau, propriamente, mas levou em consideração também a distribuição e o consumo da produção, o momento do processo produtivo, hoje, mais determinante do ritmo, da dinâmica e da vida de relações na região.

FIGURA 5 - Localização da Mesorregião Sul Baiano e Microrregião Ilhéus-Itabuna, no estado da Bahia

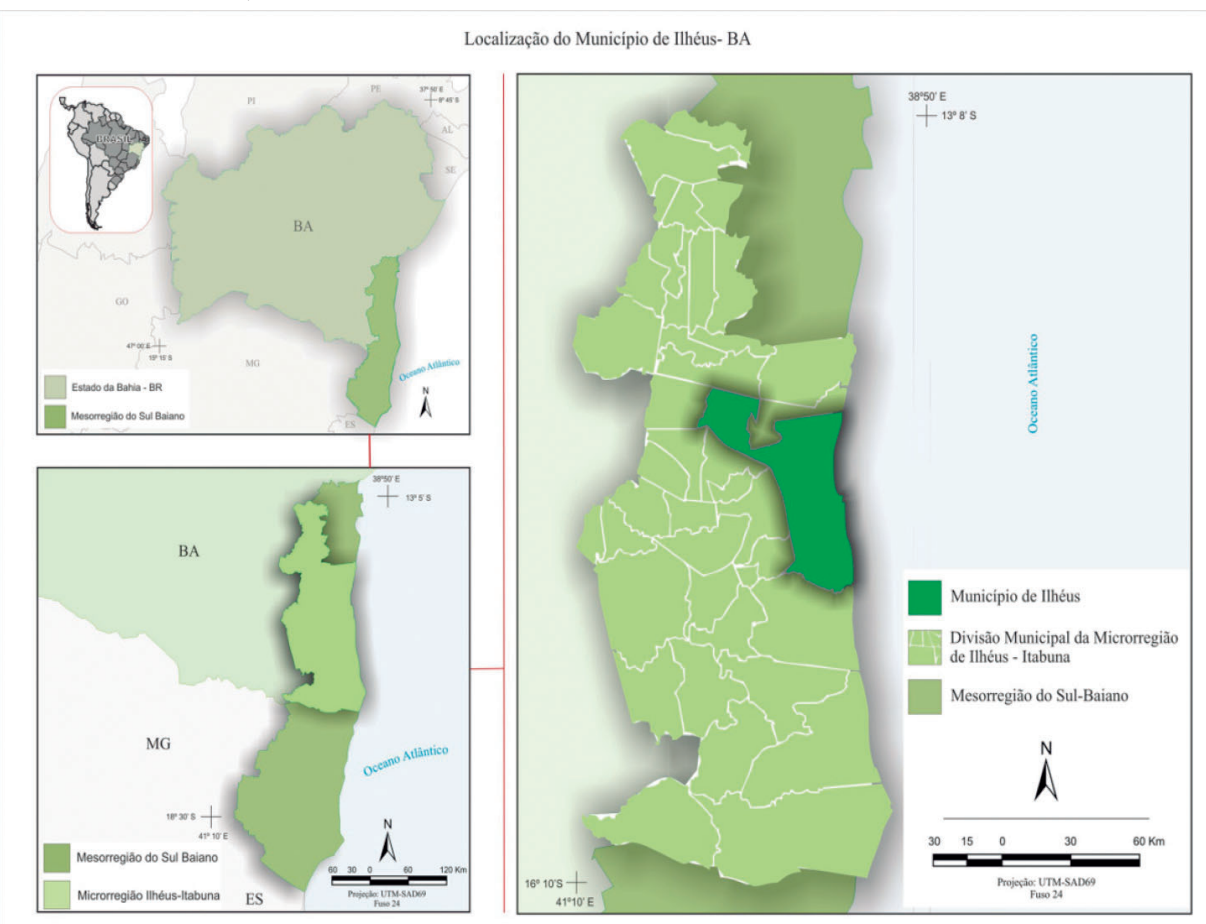

Fonte: Base cartográfica do IBGE.

Nota: Elaboração de Luís Henrique Pereira.

No ano de 1904, o cacau chegou à liderança na pauta estadual de exportação, posição que conseguiu manter até o final da República Velha, colocando 
o Brasil na posição de principal produtor mundial. Com a produção voltada para o mercado externo, exigiu-se a instalação de equipamentos técnicos que tornassem a atividade cacaueira mais eficaz. Nessa época, as ferrovias eram os equipamentos mais importantes de integração nacional. Assim, em 1904, o coronel Bento Berilo de Oliveira conseguiu uma concessão do Governo do Estado para construir e operar, por 50 anos, uma ferrovia que ligaria a cidade de Vitória da Conquista, localizada no Sudoeste da Bahia, ao Porto de Ilhéus.

Com a garantia da exploração, o coronel fez uma associação com a empresa inglesa The State of Bahia South Western Railway Company Limited e, em 1913, foi inaugurado um trecho de 59 quilômetros entre Ilhéus e Itabuna, que transportou 16.030 toneladas de amêndoas de cacau, pela primeira vez. Em 1915, foram construídos mais 35 quilômetros de ramais ferroviários, mas não em direção à Vitória da Conquista e, sim, passando pelas áreas mais expressivas de produção cacaueira, localizadas nas bacias dos rios Almada, em Água Preta (Uruçuca) e Mucambo (Ubaitaba) (VINHÁES, 2001).

A ferrovia nunca chegou a Vitória da Conquista, mas o seu pequeno trecho operou no transporte de cargas e pessoas de Itabuna a Ilhéus até 1964, ano em que foi desativada por determinação do Governo Federal. Segundo Vinháes (2001), a construção da estrada de ferro teve como objetivo transportar amêndoas de cacau, tanto que um único vagão era destinado ao fluxo das pessoas. Inicialmente não continha bancos para se sentar e o bilhete de passagem continha um aviso para trazer cadeiras para as senhoras.

O movimento de capitais e de homens na atividade cacaueira desencadeou uma série de outros movimentos que resultaram numa redistribuição da população e dos capitais para lugares mais distantes da faixa litorânea, e foi esse movimento que mobilizou a sociedade para a geração de renda, emprego e divisas para o País, que acabou por criar inúmeras vilas e cidades na região. O período do desbravamento e da conquista da região cacaueira atraiu um grande número de pessoas deslocadas pelas secas e por uma estrutura agrária extremamente singular, que chegou a estagnar o crescimento da população na cidade de Salvador, no período entre 1920 a 1940 (SANTOS, 1993).

Se em São Paulo foram as frentes pioneiras do café, nas décadas de 1940/50, e, depois, a industrialização, na década de 1960, que aumentava o número de municípios, na Região Sul da Bahia, foi a produção de amêndoas de cacau que proporcionou uma nova divisão territorial, com o surgimento de novas unidades administrativas (QUADRO 1). 
QUADRO 1 - Evolução da divisão territorial e administrativa da Microrregião Ilhéus-Itabuna (anos 1534 a 2000)

\begin{tabular}{|c|c|}
\hline Período & Denominação e ano de criação \\
\hline $\begin{array}{l}1534 \\
a \\
1900\end{array}$ & $\begin{array}{l}\text { - Vila de São Jorge dos Ilhéus (1534) } \\
\text { - Vila de N. Senhora da Assunção de Camamu (1693) } \\
\text { - Vila da Barra do Rio de Contas (1732) } \\
\text { - Vila de Santarém (1758) } \\
\text { - Vila de São Sebastião de Maraú (1761) } \\
\text { - Imperial Vila de Canavieiras (1833) } \\
\text { - Santo Antônio da Barra de Una (189o) }\end{array}$ \\
\hline $\begin{array}{l}1901 \\
\text { a } \\
1040\end{array}$ & $\begin{array}{l}\text { Itabuna (1906); Uruçuca (1929); Itacaré (1931); Ubaitaba (1933); Ipiaú (1938); } \\
\text { Una (1938) }\end{array}$ \\
\hline $\begin{array}{l}1941 \\
a \\
1984^{* *}\end{array}$ & $\begin{array}{l}\text { Década de } 1940 \\
\text { Ibirataia (1943) } \\
\text { Década de 1950 } \\
\text { Coaraci (1952); Ibicaraí (1952); Ubatã (1952); Gandu (1958); Itagibá (1958); } \\
\text { Buerarema (1959) } \\
\text { Década de 1960 } \\
\text { Itapitanga (1960); Aurelino Leal (1961); Barra do Rocha (1961); Camacan } \\
\text { (1961); Ibirapitanga (1961); Itapé (1961); Almadina (1962); Barro Preto (1962); } \\
\text { Gongogi (1962); Floresta Azul (1962); Itajú do Colônia (1962); Itajuípe(1962); } \\
\text { Itamari (1962); Mascote (1962); Pau Brasil (1962); Santa Cruz da Vitória (1962); } \\
\text { Teolândia (1962); Wenceslau Guimarães (1962) }\end{array}$ \\
\hline $\begin{array}{l}1985 \\
a \\
2000\end{array}$ & $\begin{array}{l}\text { Arataca (1985); Jussari (1985); Santa Luzia (1985); Nova Ibiá (1989); São José } \\
\text { da Vitória (1989) }\end{array}$ \\
\hline
\end{tabular}

Fonte: SEI (2001).

Notas: *Durante o período de governo do regime militar (1964/85), dado o controle rígido do sistema de governo, foi proibida a criação de novos municípios. A partir de 1985, com o fim do regime militar e com a convocação da Assembleia Nacional Constituinte (Emenda Constitucional $n^{\circ} 26$ de $27 / 11 / 1985$ ), teve início a formação de novos municípios. Para maiores detalhes do processo de criação e instalação de novos municípios ver Cataia (2001, cap. 5, 6, 7 e 8). Elaboração de Jorge Chiapetti.

Contudo, a especialização e o crescimento da economia regional da monocultura cacaueira não permitiram uma integração da região com o restante do País, pois as vias de transporte eram quase inexistentes e o isolamento era quebrado apenas pelas relações que a região estabelecia com o exterior, via transporte marítimo. 
Para Silva e Cocco (1999), o papel histórico dos portos representa a ligação de quase todas as grandes cidades com o exterior, como porta de entrada dos colonizadores e dos escravos, de um lado, e porta de saída das riquezas produzidas nos diferentes ciclos econômicos brasileiros.

O movimento portuário de Ilhéus teve início com o Porto do Arraial do Banco da Vitória, um pequeno ancoradouro às margens do rio Cachoeira, no atual bairro de Ilhéus, localizado no $\mathrm{km} 7$ da BR 415 ou Rodovia Ilhéus/Itabuna (a partir de 2013 chamada de Rodovia Jorge Amado). Desse ancoradouro eram enviados, em pequenos barcos e canoas, o cacau e outros produtos que chegavam de vários lugares, transportados nos lombos de animais, para o porto da foz do Rio Cachoeira, conhecido como Porto de Ilhéus, Porto do Cais ou Porto Fluvial (NUNES, 2001).

O Porto de Ilhéus, localizado inicialmente na baía do Pontal, recebia navios desde os tempos da navegação a vela, constituindo-se na única vinculação da região com o território brasileiro e, ao mesmo tempo, com o mundo, atribuindo a Ilhéus um papel econômico central regional.

A especialização e o aumento da produção da atividade cacaueira requeriam constantes investimentos na infraestrutura portuária, para melhorar o fluxo de embarque das amêndoas de cacau. Então, em 1911, o porto foi equipado com cais para melhorar a atracação das embarcações, com armazéns e vários serviços de dragagem no canal da baía do Pontal (FIGURA 6).

FIGURA 6 - Antigo Porto de Ilhéus, na baía do Pontal, Ilhéus, Bahia

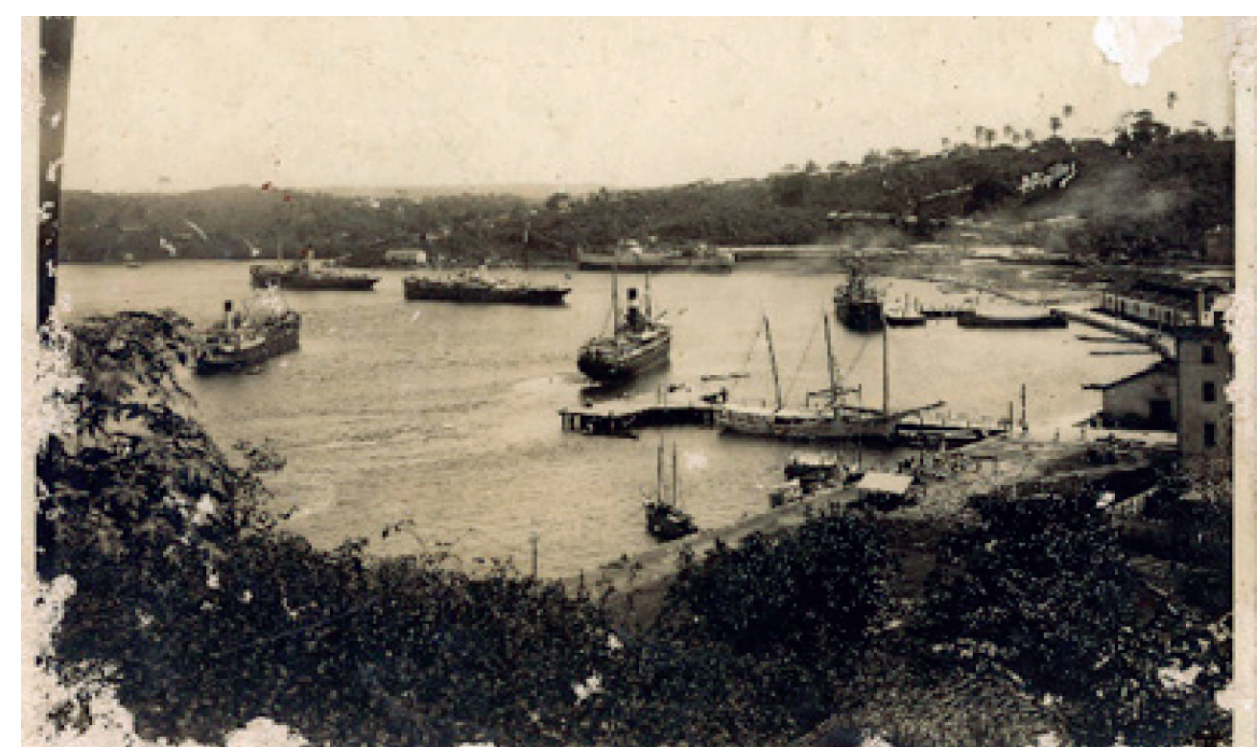

Fonte: $<$ http://www.r2cpress.com.br/?q=node/3621>. 
O historiador Carlos Alberto de Oliveira, estudando a vida portuária e o desenvolvimento urbano de Ilhéus, na década de 1920, escreveu que a primeira exportação direta para o exterior, efetuada por navios estrangeiros de grande porte, aconteceu em janeiro de 1926, quando o cargueiro Falco, da Suécia, embarcou 3.000 toneladas de cacau (OLIVEIRA, 2006). O historiador cita que, na edição de 9 de fevereiro de 1926, o jornal "Correio de Ilhéos" publicou a seguinte notícia:

\section{O Falco Seguio}

Após sete dias de permanencia em nosso porto, recebendo grande carregamento do nosso principal producto, o cacào, zarpou a 6 do corrente, com destino a New York o cargueiro Sueco "Falco", que iniciou a linha direta deste a portos consumidores, no estrangeiro.

O serviço de carregamento foi regularissimo e irrepreensivel, em nada deixando a desejar dos outros portos, mostrando-se a nossa estiva sempre habil e competente.

O "Falco" passou garbosamente pela barra, calando 17 pés, sem nenhum entrave, o que bem patenteou a efficiencia das ultimas obras effectuadas, a cargo da Companhia Industrial, levando no seu bojo 47.150 saccos de Cacào, sendo 18.000 de Wildberger \& Cia., 12.500 de Hugo Kaufmann \& Cia., 7.150 de Correa Ribeiro \& Cia., 7.000 de Agenor Gordilho e 2.500 de F. Stevenson $\&$ Cia., com destino a New-York e Boston.

Fonte: Oliveira (2006), não paginado.

Com o porto em funcionamento, tanto as exportações como as importações aumentaram. O cacau era o seu principal produto de exportação, mas, também, exportava-se piaçava, óleo de copaíba, madeiras, aguardente, couros, cocos, farinha de mandioca e peixes. As importações incluíam várias mercadorias, como louças, ferragens, vinhos, carne do Rio Grande do Sul, queijos, biscoitos, chocolates, drogas e medicamentos, cervejas, instrumentos musicais, etc. (BARROS, 2004).

Com o aumento do fluxo, principalmente das exportações, em 1970, foi construído um novo porto em mar aberto e dotado de equipamentos modernos, que possibilitavam a atracação de grandes embarcações para o carregamento de amêndoas e derivados do cacau (FIGURA 7). Foi, portanto, no litoral, pelas intensas atividades do Porto, que a cidade de Ilhéus ganhou um novo aspecto, recebeu mais investimentos e equipamentos e a vida urbana se tornou mais dinâmica. 
FIGURA 7 - Porto do Malhado, atual porto de Ilhéus, Bahia

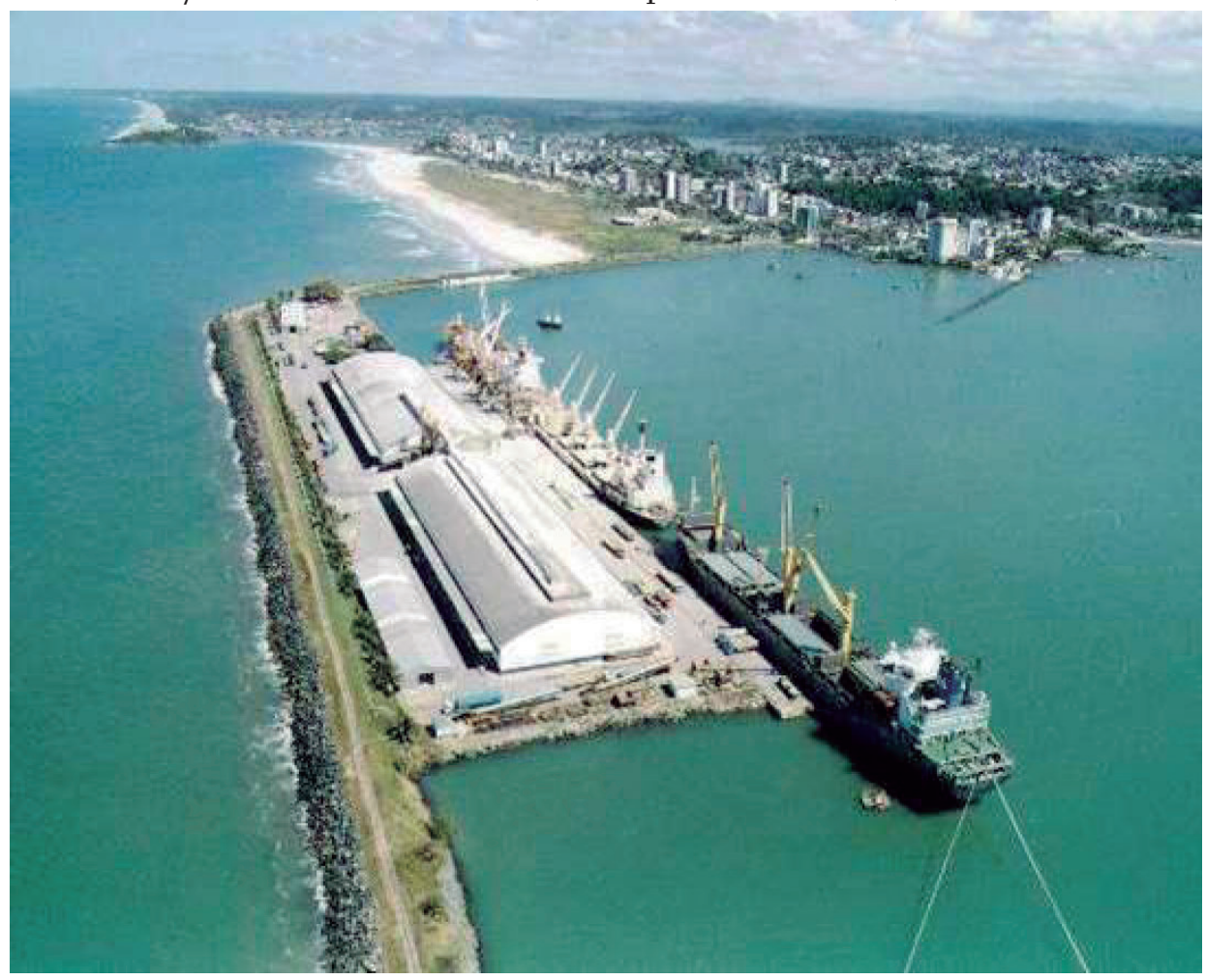

Fonte: <www.transportes.gov.br/bit/portos/ilheus/.htm>.

De toda forma, esse dinamismo é característico de "um urbanismo de fachada que reflete a condição de dependência de sua economia ao mercado externo" (SANTOS; SILVEIRA, 2005, p. 34). As aglomerações urbanas que surgiam em torno de Ilhéus, em direção ao interior, não recebiam os mesmos investimentos em equipamentos urbanos, nem gozavam socialmente das riquezas da produção cacaueira. Tais investimentos eram exclusivamente para o exercício da atividade agrícola, indispensável à expansão do modelo agro-exportador, o qual direcionava as ações e os investimentos territoriais, tudo conforme os interesses de uma classe social privilegiada e conforme os interesses e demandas do mercado internacional.

A iluminação elétrica, condição essencial para a fase industrial do modo de produção capitalista, chegou a Ilhéus em $1911^{4}$, com a construção

4 Segundo Santos e Silveira (2005, p. 37), “A primeira instalação de iluminação elétrica no país foi feita na cidade do Rio de Janeiro em 1879”. 
de uma barragem no rio Almada, cujas possibilidades técnicas de transmissão apenas serviam às residências e à iluminação pública e, ainda, com constantes períodos de interrupção no fornecimento de energia. Como a estrada de ferro, a barragem foi construída através de uma concessão para o engenheiro Evandro Pinho explorar por 30 anos. Posteriormente, essa concessão foi transferida para a Companhia Luz e Força (VINHÁES, 2001). Mesmo com a riqueza produzida pela atividade cacaueira nas três primeiras décadas do século XX, a ampliação e a regularização do fornecimento de energia elétrica em Ilhéus e região somente aconteceram em 1962, com a construção da hidroelétrica do Funil, no Rio das Contas. Assim:

As três primeiras décadas do século XX foram consideradas a fase da formação da região porque naquele período se organizou a base econômica, a monocultura cacaueira, possibilitadora da formação de uma sociedade que definiu sua estrutura e seus interesses, numa estrutura política para a manutenção daquela organização econômica e uma estrutura ideológica para a reprodução da sociedade regional (DINIZ, 1983, p. 37).

Como no restante do País, as relações sociais de produção cacaueira na região Sul da Bahia foram

tão rigorosamente caracterizadas que se pode falar, a exemplo da civilização paulista e fluminense do café, ou da nordestina da cana-de-açúcar e do couro, em uma civilização baiana do cacau (ADONIAS FILHO, 1976, p. 14).

Sem tanto exagero, é possível afirmar que a expansão da produção agrícola e da exploração mineral foi a base de um povoamento e de uma criação de riquezas, redundando na ampliação da vida de relações, em que a classe dos proprietários de terra e de capital, que sempre teve representação no exercício do poder político, destacou-se como classe hegemônica. A classe hegemônica da produção cacaueira recebeu a denominação de "coronéis do cacau". O coronel tem sua origem nos primeiros desbravadores ou pequenos comerciantes, homens que se destacaram pelo trabalho direto com a mata na formação dos cultivos de cacau e pela sua astúcia na comercialização e expropriação de terras.

O poder dos coronéis vai se ampliando com as concessões das obras públicas, da posse das terras devolutas e com a expropriação de terras dos 
pequenos agricultores e extrativistas, através da exploração do trabalho pago em produto, renda-produto; esta é uma forma de exploração da força de trabalho em que o proprietário da terra, não precisando adiantar salário, sem dispor de capital variável, paga os trabalhadores, no caso da formação dos cacauais, em produto da primeira safra da produção. É bom lembrar que a planta do cacau só produz depois de dois anos de plantio, e não é a safra mais produtivas.

$\mathrm{Na}$ introdução do livro de Ribeiro (1966, p. 9), o autor relata as diversas formas de exploração das lavouras formadas pelos pequenos agricultores pioneiros, os burareiros (denominação regional de pequenos produtores):

\footnotetext{
O pequeno lavrador fazia a sua compra, acertava pagar com o cacau, quando o colhesse. Fazia, assim, a sua conta. Cacau, é bom saber, só dá boa colheita depois de cinco anos. Então, aos primeiros frutos, aquela conta já havia crescido bastante, com juros e tudo. De modo que o burareiro, ao estrear como produtor, é já um endividado.
}

Na medida em que a classe hegemônica da atividade cacaueira, formada pelos agentes da produção e da comercialização de amêndoas de cacau, associou-se ao poder público, ampliou o seu poder e passou a obter, no plano jurídico ou material, compensações e vantagens no uso do território e, assim, comandou o processo de desenvolvimento econômico regional.

O desenvolvimento econômico defende exclusivamente interesses das classes hegemônicas e entende-se que nem sempre as preocupações econômicas demonstram sua verdadeira intencionalidade. Somente um exame detalhado do processo histórico pode mostrar, com maior precisão, se as intenções, os planos e os projetos, que se materializam em um sistema de objetos (órgãos, institutos, associações) e em um sistema de normas (leis, códigos), resultam de um debate democrático com a sociedade ou de atos deliberados por uma classe em benefício próprio.

\section{Conclusão}

Ao concluir esse texto esperamos reunir condições suficientes para demonstrar como, histórica e geograficamente (tempo e espaço), a formação territorial "para além do descobrimento", sob a ideologia do de-

5 Para essa discussão, ver Kaustsky (1968). 
senvolvimento econômico, foi se materializando conforme os desígnios condizentes com cada período.

A ideia central deste texto foi demonstrar, para professores do ensino de Geografia e de áreas afins, na universidade, como, também, no ensino médio, que a cada novo processo de transformação surgem momentos de esperança incomuns de acesso da população a uma melhor qualidade de vida. Esses momentos podem ocorrer a partir de qualquer mudança do cenário político ou econômico e transformados em ideologia de desenvolvimento.

A criação de ambientes favoráveis ao mercado, o que se caracteriza por uma "economia avançada", não possui alcance para suprir necessidades da maioria da população, nem para proporcionar o tão propagado desenvolvimento. Priorizar investimentos em função dos atores hegemônicos, de necessidades alheias e de funções distantes gera problemas para todos, cria desordem, fragmentação e alienação e não contribui para o acesso ao bem viver de toda a sociedade, mas, sim, ao uso corporativo do território.

A despeito de toda a riqueza produzida nos áureos períodos da produção do cacau na região sul da Bahia, nem o lugar, nem as elites, nem os trabalhadores se beneficiaram, ou seja, no lugar também se aprofundam as fragmentações sociais e territoriais e, por conseguinte, esgarçou-se qualquer possibilidade de solidariedade orgânica na região e, afinal, da região com o território nacional. É todo um processo de fragmentação do território, resultado de forças organizacionais, as quais subordinam tanto a instalação de sistemas de objetos, como de sistemas de ações, organizando-os segundo os desígnios do capital, tornando, assim, nossa região em espaço derivado do projeto de acumulação e de benefícios de outros lugares.

Para que o dito popular "a sociedade que não conhece seu passado está sujeita a repetir os mesmos erros" não se concretize, é urgente repensarmos, também nas salas de aula, as bases econômicas e políticas que conduzem nosso desenvolvimento, bases essas sobre as quais nós pouco nos atrevemos a pensar, mas é necessário pensá-las para que façamos o território, que estamos construindo, dialogar com o futuro e não mais com o passado. 


\section{REFERÊNCIAS}

ADONIAS FILHO. Sul da Bahia: chão de cacau. Rio de Janeiro: Civilização Brasileira, 1978.

BARBOSA, C. R. A. Notícia histórica de Ilhéus. 3. ed. Itabuna: [s.n.], 1994

BARROS, F. B. de. Memória sobre o município de Ilhéus. 3. ed. Ilhéus: Editus. 2004.

BONDAR, G. A cultura de cacao na Bahia. Salvador: Instituto do Cacau da Bahia. 1938.

BOSI, A. Dialética da colonização. São Paulo: Companhia das Letras. 1992.

COSTA, A. T da. O cacau é show: deliciosas histórias do mundo do chocolate. São Paulo: IPSIS, 2008.

CATAIA, M. A. Território nacional e fronteiras internas: a fragmentação do território brasileiro. 2001. 163 f. Tese (Doutorado em Geografia) - Departamento de Geografia da Faculdade de Filosofia, Letras e Ciências Humanas da Universidade de São Paulo, São Paulo, 2001.

CHIAPETTI, J. O uso corporativo do território brasileiro e o processo de formação de um espaço derivado: transformações e permanências na região cacaueira da Bahia. 2009. 205 f. Tese (Doutorado em Geografia) - Universidade Estadual de São Paulo Júlio de Mesquita Filho-UNESP, Rio Claro, SP, 2009 .

DINIZ, J. A. F. A região cacaueira da Bahia. Recife: Sudene, 1983.

FAORO, R. Os donos do poder: formação do patronato político brasileiro. 10. ed. São Paulo: Globo; Publifolha, 200o. v. 1. 
FURTADO, C. Formação econômica do Brasil. 15. ed. São Paulo: Nacional, 1977.

1989.

A fantasia desfeita. 3. ed. Rio de Janeiro: Paz e Terra.

MARX, K. [1894]. O capital: crítica da economia política. São Paulo: Nova Cultural,1996. (Coleção Os Economistas, 2.).

NUNES, M. C. História portuária de Ilhéus, 1915-1942. 2001. Monografia (Graduação em História) - Departamento de Filosofia e Ciências Humanas, Universidade Estadual de Santa Cruz (UESC), Ilhéus, 2001.

OLIVEIRA, C. A. de. Ilhéus/BA, a Princesa do Sul: vida portuária e desenvolvimento urbano na década de 1920. In: CIDADE REVELADA - I FÓRUM NACIONAL DE CONSELHOS DE PATRIMÔNIO CULTURAL, 9., 2006, Itajaí, SC. Anais... Itajaí, 2006. Disponível em: <http://cidadereveladaadm.itajai.sc.gov.br/ arquivos/COM-41.pdf. $>$. Acesso em: 18 jul. 2010.

OLIVEIRA, F. de. Os direitos do antivalor. Petrópolis: Vozes, 1998.

O elo perdido: classe e identidade de classe na Bahia. São Paulo: Perseu Abramo, $200 z$ a.

PRADO JUNIOR, C. História econômica do Brasil. 17. ed. São Paulo: Brasiliense, 1974.

RIBEIRO, D. O processo civilizatório: etapas da evolução sociocultural. São Paulo: Companhia das Letras. 1998.

A navegação venturosa: ensaios sobre Celso Furtado.

São Paulo: Boitempo, 2003b.

RIBEIRO, S. Contos do cacau: tipos e cenários do rio de Contas. Rio de Janeiro: Pongetti, 1966. 
SAMPAIO, P. de A. Os períodos da história do Brasil. In: STEDILE, J. P; SAMPAIO, P. de A. História, crise e dependência do Brasil. 5. ed. São Paulo: Secretaria Operativa da Consulta Popular, 2003.

SANTOS, M. Zona do cacau: introdução ao estudo geográfico. 2 ed. São Paulo: Editora Nacional, 1957.

_. O trabalho do geógrafo no terceiro mundo. São Paulo: Hucitec, 1978.

Espaço e sociedade: ensaios. Petrópolis: Vozes, 1979.

A urbanização brasileira. São Paulo: Hucitec, 1993.

. Por uma outra globalização: do pensamento único à consciência universal. 12. ed. São Paulo: Record, 2005a.

SANTOS, M.; SILVEIRA, M. L. O Brasil: território e sociedade no início do século XXI. 7 ed. Rio de Janeiro: Record, $2005 \mathrm{~b}$.

A natureza do espaço: técnica e tempo, razão e emoção. 4. ed. São Paulo: EDUSP, 2006.

SCHWARTZ, S. B. Segredos internos: engenhos e escravos na sociedade colonial. São Paulo: Companhia das Letras, 1988.

SUPERINTENDÊNCIA DE ESTUDOS ECONÔMICOS E SOCIAIS. Evolução territorial e administrativa do estado da Bahia: um breve histórico. Salvador: SEI, 2001. (Série Estudos e Pesquisa).

SILVA, G.; COCCO, G. (org.). Cidades e portos: os espaços da globalização. Rio de Janeiro: DP\&A, 1999.

VINHÁES, J. C. São Jorge dos Ilhéus: da capitania ao fim do século XX. Ilhéus: Editus, 2001. 


\section{ANÁLISE DO \\ TERRITÓRIO EM \\ MICHEL FOUCAULT: \\ o território como locus do \\ poder $^{1}$}

Maria Cristina Rangel

Celene Tonella

\section{INTRODUÇÃO}

O objetivo desse artigo é demonstrar as proposições de Michel Foucault na análise do território na obra "Segurança, território, população: curso dado no Collège de France, em 1977 - 1978”.2. Ressalta-se, portanto, que este artigo não tem como intuito travar um diálogo entre diversos autores sobre o conceito de território, mas perscrutar o conceito de território em Foucault (2008), procurando as intermediações da sociedade com o espaço geográfico.

Por meio da referida obra descobriu-se que Foucault aponta alguns elementos para análise da dinâmica do território, entre elas a de que este se constitui a partir da instalação dos mecanismos de poder, e cabe ao investigador, no entendimento do território, tornar visíveis estes mecanismos e os focos de resistência. Além disso, propõe que esta análise seja relacional, já que o poder não é uma "coisa", mas relações entre os sujeitos que visam alcançar ou manter o poder, mesmo que não o consigam. Portanto, é necessário problematizar o território, interrogar sempre quais são os obstáculos que o mesmo traz ao exercício do poder e as artimanhas construídas para eliminá-los.

\footnotetext{
Trabalho originalmente apresentado no X Encontro Nacional da Associação Nacional de Pós-Graduação e Pesquisa em Geografia (ENANPEGE). Unicamp, Campinas, 7 a 10 de outubro de 2013 .

2 Todas as citações são da obra: FOUCAULT, Michel. Segurança, território, população: curso dado no Collège de France (1977-1978). São Paulo: Martins Fontes, 2008.
} 
Dependendo dos problemas colocados pelo território em relação ao exercício do poder, os mecanismos utilizados acontecem de formas específicas, múltiplas e em diferentes escalas. Desta forma, a configuração que o território assumirá não é procedente de uma forma única, por exemplo, hierarquizada, horizontal, vertical, ou mantendo células individuais, articuladas entre si. Por fim, indica que os procedimentos de poder voltam-se para certa multiplicidade de sujeitos na tentativa de neutralizar os que são adversários e cooptar os demais. Entre esses procedimentos estão os discursos imperativos que indicam o que fazer, como fazer, em que tempo e lugar, com qual objetivo, induzindo a subjetivações e mudanças comportamentais. Assim, por exemplo, definem-se os traçados das estradas e, por sua vez, excluem-se as áreas que não serão atendidas por essa infraestrutura de transporte.

É a partir dessa proposição metodológica que Foucault analisa o projeto da cidade-capital na La Métropolitée (e a irradiação da capitalização do território); o da cidade arquitetada ou "artificial" de Richelieu (a forma sendo o suporte do exercício exato da função); e a cidade "real" de Nantes (França) (o exercício do poder em um espaço construído, o meio), enfocando a questão da disciplina e da segurança. Por meio desses três exemplos de cidade se identificou a preocupação de Foucault com a análise da relação forma-função-conteúdo-símbolo, com as relações homem-meio e a multiplicidade de conceitos que intercambiam a análise territorial, preocupações próprias da Geografia.

\section{O território em Foucault}

Para Foucault, o território se concretiza em extensão, limites e fronteiras, e é locus do exercício do poder supremo, o qual ele especifica como sendo de um soberano individual ou coletivo. Inicialmente, de forma esquemática, Foucault conduz a um entendimento de que espacialmente

a soberania se exerce nos limites de um território, a disciplina se exerce sobre o corpo dos indivíduos e, por fim, a segurança se exerce sobre o conjunto de uma população (2008, p. 15-16).

Faz isto para, posteriormente, desconstruir esse raciocínio linear e partir para a análise relacional entre esses elementos. Demonstra, por exemplo, que o território não precisa ser necessariamente povoado para 
ser dominado, e que o exercício da soberania trabalha com certa multiplicidade de sujeitos ou de um povo, que é preciso organizar, disciplinar e evitar revoltas.

Antes, porém, de iniciar o curso propriamente dito, Foucault apresenta cinco "proposições, no sentido de indicações de opções [...]" (2008, p. 3), para análise dos mecanismos de poder. Essas proposições sobre o poder conduzem a uma metodologia de análise do território como locus dos "mecanismos de poder". Como primeira opção, alerta que

não é de forma alguma uma teoria geral do que é o poder [...], mas da análise [de um] conjunto de procedimentos, [de] mecanismos de poder (2008, p. 3-4).

Na segunda indicação de opção de análise está a questão da necessidade do consentimento, consciente ou não, dos comandados, para que o poder possa ser exercido. São criados, para tanto, mecanismos que induzem a comportamentos, como a sedução, recompensa, proibição, censura, interdição, repressão, coação, recurso à tradição e práticas exemplares, autoridade, lealdade, ritual das circunstâncias. Em outros termos, "o poder não se funda em si mesmo e não se dá a partir de si mesmo” (2008, p. 4), pois ele é relacional, necessita do "outro" ou dos "outros" para se exercitar.

Em terceiro lugar, essa análise dos mecanismos de poder, "tem a ver com a filosofia, isto é, com a política da verdade, porque não vejo muitas outras definições para a palavra 'filosofia' além dessa” (2008, p. 5). Dito de outra maneira, o saber constituído institui verdades e inibe vozes dissonantes ao poder da hierarquia social. Cabe a nós, portanto, descortinar as lutas pela verdade, as políticas da verdade, o que faz com que se instituam certas verdades em detrimento de outras, no comando do território.

Como quarta indicação de opção, Foucault fala da necessidade de se identificar a procedência de quem fala, como fala, de onde fala, em nome de quem fala, fala sobre o quê, em quais circunstâncias, para quem fala, utiliza-se de quais meios, com quais estratégias, quais são e a quem se destinam as ordens imperativas naquilo que fala, e os efeitos materiais e/ ou simbólicos esperados. Detectar os objetivos dos discursos imperativos mais velados e polifônicos. É uma opção que podemos utilizar para interrogar materiais discursivos na Para Foucault, o território se concretiza em extensão, limites e fronteiras, e é locus do exercício do poder supremo, o qual ele especifica como sendo de um soberano individual ou coletivo. Inicialmente, de forma esquemática, Foucault conduz a um entendimento de que espacialmente 
a soberania se exerce nos limites de um território, a disciplina se exerce sobre o corpo dos indivíduos e, por fim, a segurança se exerce sobre o conjunto de uma população" (2008, p. 15-16).

Faz isto para, posteriormente, desconstruir esse raciocínio linear e partir para a análise relacional entre esses elementos. Demonstra, por exemplo, que o território não precisa ser necessariamente povoado para ser dominado, e que o exercício da soberania trabalha com certa multiplicidade de sujeitos ou de um povo, que é preciso organizar, disciplinar e evitar revoltas.

Antes, porém, de iniciar o curso propriamente dito, Foucault apresenta cinco "proposições, no sentido de indicações de opções [...]" (2008, p. 3), para análise dos mecanismos de poder. Essas proposições sobre o poder conduzem a uma metodologia de análise do território como locus dos "mecanismos análise do território, como: reportagens, entrevistas, artigos, contos, depoimentos, palestras, seminários, filmes, documentários e teses.

Por último, a quinta indicação de opção: a relação entre a luta e a verdade,

essa relação séria e fundamental entre a luta e a verdade, creio que não faz nada mais que se teatralizar, se descarnar, perder o sentido e a eficácia nas polêmicas internas ao discurso teórico (2008, p. 6).

Há, assim, uma distinção entre a verdade e as lutas travadas para se definir qual prevalecerá e se tornará ação. No que se refere ao território, a luta é pela apropriação real e simbólica dos bens sociais (bens naturais tornados recursos e os bens culturais) ali existentes. Cada soberano que o disputa, mune-se de indicativos de verdade, como a autoridade, tradição, lealdade, o saber e o conhecimento, para fazer distinções, separações, hierarquizações, interdições e, assim, conseguir com que suas ordens surtam efeitos de verdade, resultem em práticas intencionadas. As palavras das pessoas quando colocadas no "degrau de baixo" não são acolhidas, aceitas. Não tendo a energia social da verdade, soam sem importância, sem efeitos; não acolhem respeito ou temor, não suscitam adesões de outros humanos. Além disso, os inferiorizados, supostamente desprovidos de saber, não devem falar o território (ou suas palavras não devem ser levadas a sério). Como não falam, não são ouvidos e nem suas falas são reproduzidas, repetidas à exaustão até se tornarem verdades. Nas relações de poder, esses são os que devem, docilmente, ouvir e obedecer. Devem ser dóceis e úteis aos que mandam. 
Ao término da apresentação dessas considerações, Foucault parte para análise dos mecanismos de disciplina e dispositivos de segurança. Tem início seu curso no Collège de France. Para exemplificar "a repartição espacial" (2008, p. 17) no intuito de resolver os problemas da circulação colocados pelas cidades dos séculos XVIII e início do século XIX, cidades muradas, jurídico-administrativamente independentes, com nítida separação cidadecampo, Foucault toma três exemplos, sendo o primeiro o projeto de $\mathrm{La}$ Métropolitée; o segundo o da cidade "artificial" de Richelieu; e, por último, a cidade "real" de Nantes (França). É na análise dessas cidades que procuramos identificar as problemáticas do território.

\section{O PROJETO DA LA MÉTROPOLITÉE E A CAPITALIZAÇÃO DO TERRITÓ- RIO: "[...] UMA FORMA SIMBÓLICA CAPAZ DE GARANTIR A FUNÇÃO”}

Aqui Foucault recorre a um texto escrito em meados do século XVII “[...] produzido por uma pessoa chamada Alexandre Le Maitre (1682), com o título de La Métropolitée" (2008, p. 18), sobre o projeto de uma cidade-capital e sua relação com o território. "E o problema de La Métropolitée é o seguinte: deve haver uma capital num país e em que essa capital deve consistir?" (2008, p. 18). Segundo Foucault, Le Maître analisa o Estado a partir da metáfora do edifício com seus andares composto por camponeses, artesãos, soberano e oficiais:

As fundações do edifício, as que estão na terra, debaixo da terra, que não vemos, mas que asseguram a solidez do conjunto são, é claro, os camponeses. As partes comuns, as partes de serviço do edifício são, claro, os artesãos. Quanto às partes nobres, as partes de habitação e de recepção, são os oficiais do soberano e o próprio soberano. A partir dessa metáfora arquitetônica, o território também deve compreender suas fundações, suas partes comuns e suas partes nobres (2008, p. 18).

Assim, distribuem-se, pelo território do Estado, tal qual a organização social, os camponeses pelos campos, os artesãos nas pequenas cidades e o soberano, seus oficiais, artesãos e comerciantes, na capital. As fundações ficam no campo, as partes comuns são as pequenas cidades, e a parte nobre, o centro de um círculo, a capital. Neste exemplo, a relação entre a capital e o território vai assumindo diversas formas. Dito de outra maneira, vão-se criando diversos mecanismos para a manutenção do poder do soberano. A primeira relação com o território assume uma forma geométrica, a de círculo, pois: 
Uma capital que estivesse na extremidade de um território comprido e de forma irregular não poderia exercer todas as funções que deve exercer. De fato, e é aí que a segunda relação aparece, essa relação entre a capital e o território tem de ser uma relação estética e simbólica (2008, p. 19).

Uma terceira relação capital-território é política, ou seja, o território precisa ser abrangido pela "rede geral das leis e dos decretos do soberano" (2008, p. 19). Chama-nos a atenção a concepção de rede em Foucault, como trama dos elementos políticos de poder, que irão caracterizar o território.

A quarta relação capital-território diz respeito ao papel moral que a capital deverá desempenhar, ser fonte de difusão de "tudo o que é necessário impor às pessoas quanto a sua conduta e seus modos de agir" (2008, p. 19). Deve ser, também, difusora do conhecimento:

A capital deve ser o lugar em que os oradores sacros sejam os melhores e melhor se façam ouvir, deve ser também a sede das academias, pois as ciências e a verdade devem nascer aí para então se difundir no resto do país.

$[\ldots]$

E, enfim, um papel econômico: a capital deve ser o lugar do luxo para que constitua um lugar de atração para as mercadorias que vêm do estrangeiro, e ao mesmo tempo deve ser o ponto de redistribuição pelo comércio de certo número de produtos fabricados, manufaturados, etc. (2008, p. 19).

Em resumo, a capital desempenhará uma relação simbólica, estética, política, moral, religiosa, sede da produção do conhecimento, enfim, realizará o efeito demonstração de poder por meio do território.

O que se pode inferir, a partir desse projeto, sobre a relação cidadeterritório? Qual é a definição de cidade contida nesse projeto? Qual é a reflexão que se faz sobre a cidade e a questão da soberania? A cidade é o ponto de irradiação do poder. A cidade fica no centro do círculo, para, supostamente, irradiar o poder de igual forma em todo o território. Neste projeto cidade-capital, a

relação da soberania com o território é que é essencialmente primeira e que serve de esquema, de chave para compreender o que deve ser uma cidade-capital e como ela pode e deve funcionar (2008, p. 19). 
É o problema da relação cidade-capital e soberania que vai influenciar nas diversas funções criadas para esta cidade-capital:

Um bom soberano, seja ele um soberano coletivo ou individual, é alguém que está bem situado no interior de um território, e um território que é civilizado no que concerne à sua obediência ao soberano é um território que tem uma boa disposição espacial (2008, p. 20).

Há, assim, um esforço de se fundir, num único Estado, a soberania, o domínio territorial e a economia. Então, território, nesse projeto, é o receptáculo das relações de poder do soberano, organizado de tal forma em torno de uma capital - espaço capitalizado - que represente a

sede da soberania e ponto de circulação política e comercial [...]. [Enfim, neste projeto] a cidade-capital é pensada [...] em função das relações de soberania que se exercem sobre um território (2008, p. 20).

Então, primeiramente, tem-se o espaço como receptáculo de relações de poder, para, num segundo momento, exercer-se a soberania através de mecanismos de poder no interior do espaço tornado território. Enfim, a soberania, para ser exercida, precisa se expressar através do território, definindo suas funções. Quanto ao sentido escalar,

de fato, no caso precedente, La Métropolitée de Le Maitre, a organização da cidade era pensada essencialmente dentro da categoria mais geral, mais global do território" (2008, p. 21).

Os elementos analíticos desse espaço são problematizados se considerando os objetivos do soberano - o poder -; a relação forma-conteúdo; o símbolo, que comunica uma determinada relação; a trama de relações concretizadas em um território e a rede de normatizações políticas e jurídicas.

\section{RICHELIEU - A CIDADE ARTIFICIAL: “FORMA SENDO O SUPORTE DO EXERCÍCIO EXATO DA FUNÇÃO”}

Outro exemplo apresentado por Foucault é o da cidade disciplinar, de uma "cidade artificial", arquitetada, 
uma cidadezinha chamada Richelieu, que foi construída nos confins da Tauraine e do Poitou, que foi construída a partir de nada, precisamente. Onde não havia nada, construiu-se uma cidade (2008, p. 21).

Cidade construída tendo como referência o acampamento romano "que, na época, acabava de ser reutilizado na instituição militar como instrumento fundamental de disciplina" (2008, p. 21), aqui refletida no espaço. Não pensada a partir de um território maior do que ela, como no projeto cidade-capital, mas

a partir de uma figura geométrica que é uma espécie de módulo arquitetônico, a saber, o quadrado ou o retângulo, por sua vez subdividido por cruzes, em outros quadrados ou outros retângulos (2008, p. 21-22),

com suas "simetrias" e "dessimetrias" bem calculadas.

Por essa forma geométrica, forma material, concreta, disciplina-se certa ordem social, a própria distribuição das diversas funções da cidade: residencial, comercial, a praça, a igreja... Cada uma dessas funções é pensada de acordo com objetivos claros: garantir a circulação das pessoas, mercadorias e estabelecer a "diferença de status social, diferença de fortuna, etc." (2008, p. 23), de acordo com o padrão de construção das moradias e dos bairros. Neste exemplo, tem-se a "Forma sendo o suporte do exercício exato da função" (2008, p. 24). Como diz o referido autor:

Creio que, nesse esquema simples, encontramos exatamente o tratamento disciplinar das multiplicidades no espaço, isto é, [a] constituição de um espaço vazio e fechado, no interior do qual vão ser construídas multiplicidades artificiais organizadas de acordo com o tríplice princípio da hierarquização, da comunicação exata das relações de poder e dos efeitos funcionais específicos dessa distribuição, por exemplo, assegurar o comércio, assegurar a moradia, etc. (2008, p. 23).

Nos exemplos anteriores temos duas formas de tentativa de alisamento territorial. Ditos de outra maneira têm-se duas formas diferentes de lidar com a multiplicidade de interesses em um território. No primeiro caso, há o soberano que capitaliza o território para acabar com as indisciplinas à ordem posta, com o objetivo de exercer o poder. No segundo caso, o soberano é o arquiteto do espaço disciplinado da cidade. Há uma tentativa de 
tratar a cidade em sua horizontalidade como o edifício utópico do projeto da La Métropolitée. As relações de poder irão se estabelecer em um recorte territorial menor - a cidade, em que cada parte da cidade tem funções e objetivos distintos quanto à localização e formas. Neste exemplo se nota a preocupação de Foucault com a relação forma-função-comunicação de relações de poder. Estabelece-se, de antemão, um lugar para cada forma de relação. As multiplicidades são artificialmente organizadas

de acordo com o tríplice princípio da hierarquização, da comunicação exata das relações de poder e dos efeitos funcionais específicos dessa distribuição (2008, p. 23).

Então, antes do território, havia o espaço esvaziado das redes, das formas-funções-conteúdos das tramas do poder. O território se constitui posteriormente ao espaço. É possível deduzir que espaço é tudo o que existe antes da efetivação das relações de poder; esse espaço vazio é o espaço esvaziado de relações de poder. Na medida em que estas relações se estabelecem, constitui-se o território.

\section{NANTES E A COMPLEXIDADE DO TERRITÓRIO CONSTRUÍDO: O MEIO}

Num terceiro exemplo, diferentemente dos dois exemplos anteriores, Foucault incorpora o "meio" às relações de poder (relação homem/ homem/meio). Na medida em que a ação sobre o espaço pelo poder do soberano incorpora o que Foucault chama de meio, a forma de intervenção se torna mais complexa. De arquiteto, o soberano passa a ser, também, "e quase ao mesmo tempo, regulador de um meio" (2008, p. 39). Como outra forma de disciplinamento territorial, Foucault toma como referência um projeto pensado a partir dos problemas suscitados pela cidade "real" de Nantes (França), "apresentado por uma pessoa chamada Vigné de Vígny, sobre os problemas concretos desta cidade" (2008, p. 24), como: garantir a higiene, o comércio, a vigilância, enfim, a circulação de pessoas e mercadorias dentro de determinados limites de segurança tanto do aspecto físico da população - por exemplo, evitando miasmas, estupros, assassinatos - e quanto ao patrimônio - roubos, saques, invasões e subvenções. Tudo isto tendo como objetivo para os que detêm o poder, evitar o flagelo, as revoltas, o esgarçamento das relações de poder, que se devem manter dentro de limites políticos, econômicos e socialmente aceitos, tolerados. 
Neste exemplo, o disciplinamento espacial não irá partir do nada, do vazio, ou do esvaziamento para a construção de uma cidade-capital,

[...] uma forma simbólica capaz de garantir a função. Tão pouco será uma $[\ldots]$ boa forma sendo o suporte do exercício exato da função [, como no caso de Richelieu:] E o problema de Nantes é, evidentemente, desfazer as aglomerações desordenadas, abrir espaço para as novas funções econômicas e administrativas, regulamentar as relações com o entorno rural e, enfim, prever o crescimento (2008, p. 23, 24).

Segundo Foucault, este é um caso significativo porque,

$1^{0}-[\ldots]$ não se trata mais de construir, dentro de um espaço vazio ou esvaziado $[\ldots] ; 2^{\circ}-[\ldots]$ não se trata de reconstruí-la de tal modo que se atingisse um ponto de perfeição, como numa cidade disciplinar; $3^{\circ}$ - vai se planejar considerandose a polifuncionalidade dos elementos da cidade; $4^{\circ}$ - vai se trabalhar com o futuro, isto é, $[\ldots]$ vai se abrir para um futuro não exatamente controlado nem controlável, não exatamente medido nem mensurável, e o bom planejamento da cidade vai ser precisamente: levar em conta o que pode acontecer (2008, p. 26).

Dessa maneira, vai-se partir de uma cidade existente, em que a reflexão sobre segurança (que recai sobre a população) e não somente a disciplina (que recai mais sobre os indivíduos, com objetivos nítidos de normatizar relações sociais através do controle do espaço), contará com a multifuncionalidade de cada espaço da cidade. Portanto, não se buscará a perfeição da relação forma-função-símbolo, como nas cidades disciplinares, mas sabendo da impossibilidade dessa perfeição, vai-se trabalhar com probabilidades, com planejamento, com a previsibilidade do que poderá acontecer:

Trata-se simplesmente de maximizar os elementos positivos, de poder circular da melhor maneira possível, e de minimizar, ao contrário, o que é risco e inconveniente, como o roubo, as doenças, sabendo perfeitamente que nunca serão suprimidos. Isso nunca pode ser anulado, logo se vai trabalhar com probabilidades (2008, p. 26).

Os mecanismos de segurança pautar-se-ão pela possibilidade de controle através de 
estimativas de probabilidade [do uso da cidade, do controle dos fluxos, dos] elementos que se produzem, [das] unidades que se acumulam espacialmente.

Digamos para resumir isto tudo que, enquanto a soberania capitaliza um território, colocando o problema maior da sede do governo, enquanto a disciplina arquiteta um espaço e coloca como problema essencial uma distribuição hierárquica e funcional dos elementos, a segurança vai procurar criar um ambiente em função de acontecimentos ou de séries de acontecimentos ou de elementos possíveis, séries que vai ser preciso regularizar num contexto multivalente e transformável (2008, p. 27).

As variáveis espaciais serão consideradas para se fazer previsões, identificar probabilidades e acontecimentos aleatórios. Estas variáveis espaciais são colocadas pelo que Foucault vai chamar de meio: "O espaço em que se desenrolam as séries de elementos aleatórios é, creio, mais ou menos o que chamamos de meio" (2008, p. 27). Mas, afinal, o que vem a ser o meio e como este faz parte dos mecanismos de segurança de um dado território?

O que é o meio? É o que é necessário para explicar a ação à distância de um corpo sobre outro. É, portanto, o suporte e o elemento de circulação de uma ação. [Enfim:] O meio é um conjunto de dados naturais, rios, pântanos, morros, é um conjunto de dados artificiais, aglomerações de indivíduos. Aglomerações de casas, etc. O meio é certo número de efeitos, que são efeitos de massa que agem sobre todos os que aí residem. É um elemento dentro do qual se faz um encadeamento circular dos efeitos e das causas, já que o que é efeito, de um lado, vai se tornar causa, do outro (p. 28). [Ou seja,] o meio aparece como um campo de intervenção [em que:] vaise procurar atingir, precisamente, uma população. Ou seja, uma multiplicidade de indivíduos que são e que só existem profunda, essencial, biologicamente ligados à materialidade dentro da qual existem. O que vai se procurar atingir por esse meio é precisamente o ponto em que uma série de acontecimentos, que esses indivíduos, populações e grupos produzem, interferem com acontecimentos de tipo quase natural que se produzem ao redor deles (2008, p. 27-28).

A intervenção no meio tem um propósito, que é criar mecanismos de segurança para que, num conjunto de relações, a população passe a se comportar de acordo com o que é pré-determinado. Essa irrupção da naturalidade 
agora $[\ldots]$ aparece como interseção entre uma multiplicidade de indivíduos que vivem, trabalham e coexistem uns com os outros num conjunto de elementos materiais que agem sobre eles e sobre os quais eles agem de volta (2008, p. 29).

Multiplicidade, coexistência, conjunto de materiais e artifícios imbricados na produção e organização do espaço.

Parte-se, portanto, do espaço construído, edificado, modificado pela ação humana para se pensar as relações de poder. Contemplando, inclusive, os aspectos primeiros onde se constroem essas relações (aspectos físicos) como elementos que são também parte dessas relações.

\section{Conclusão}

Procurou-se, no curso de Foucault dado no College de France (19771978), destacar sua concepção de território, através, principalmente, dos três exemplos de cidade utilizados por ele. Nesta perscrutação se percebeu que Foucault aponta alguns elementos para análise da dinâmica do território.

Primeiramente, não existem procedimentos únicos de análise do território, pois cada um apresentará obstáculos particulares às relações de poder. Portanto, é necessário problematizar o território. Nesse sentido, o território se constitui a partir da instalação dos mecanismos de poder, e cabe ao investigador, no entendimento do território, tornar visíveis estes mecanismos e os focos de resistência. Desvendar os "efeitos de saber" (2008, p. 5) produzidos socialmente e as táticas de poder dessa luta, assim como as manipulações das formas e funções territoriais.

Em segundo lugar, o território é o locus do poder supremo, que na época estudada por Foucault, era o poder do soberano e a soberania se exercia no limite de um território.

Em terceiro lugar, a análise do território deve ser relacional, pois:

trata-se simplesmente de saber por onde isso [poder] passa, como se passa, entre quem e quem, entre que ponto e que ponto, segundo quais procedimentos e com quais efeitos (2008, p. 3).

Já que o poder não é uma "coisa", mas relações entre os sujeitos que visam à manutenção do poder, mesmo que não consigam. Portanto, as relações de poder não são "fundadas em si mesmas" (2008, p. 4). 
Em quarto lugar, o exercício da soberania

indica sempre, é claro, uma certa multiplicidade, mas que vai ser tratada justamente seja como a multiplicidade de sujeitos, seja como a multiplicidade de um povo (2008, p. 16).

É sobre esta multiplicidade de sujeitos que irá atuar um conjunto de procedimentos, entre eles, os imperativos do poder. Então, deve-se deixar clara a procedência de quem fala, fala por quem, como fala, quando fala e objetivos dos discursos imperativos mais velados e polifônicos - já que "nunca um sujeito falante pode criar sozinho e a partir da sua palavra [...]" (2008, p. 6). Enfim, lastima-se, para a Geografia, que Foucault tenha neste curso de 1977-1978, afastado-se da análise espacial para se concentrar no que ele denominou de governamentalidade, passando para inventariar as questões da arte de governar. Contudo, mesmo não dando continuidade ao enfoque do território, contribuiu na construção de alguns indícios metodológicos para sua análise, como vimos anteriormente. 


\section{REFERÊNCIAS}

FOUCAULT, M. Segurança, território, população: curso dado no Collège de France (1977-1978). São Paulo: Martins Fontes, 2008. 


\section{A PAISAGEM NO ESPAÇO \\ DA VIDA: \\ do vivido ao refletido}

Lurdes Bertol Rocha

Maria Cristina Rangel

Camila Santana Carriço

Karen de Jesus

\section{INTRODUÇÃO}

Este artigo apresenta os resultados de um dos grupos de trabalho no interior do Programa de Consolidação das Licenciaturas (PRODOCÊNCIAMEC/SESu/DEPEM). Na Universidade Estadual de Santa Cruz (UESC), os Coordenadores de Curso das licenciaturas se reuniram e construíram o Projeto "IDENTIDADE, ALTERIDADE E PAISAGEM: a educação pelo olhar", para atender ao edital Prodocência/2007. Este projeto teve por objetivo contribuir para a superação da dicotomia entre os ramos do conhecimento, demonstrando a articulação destes na vida, qualificando a formação geral, através da leitura da paisagem, numa perspectiva inclusiva e preservacionista, em diferentes contextos, por professores e estudantes dos cursos de licenciatura da UESC e da educação básica. A estrutura organizacional da proposta constituir-se-ia de um coordenador geral, dez coordenadores de área, dez professores orientadores e professores consultores da UESC, um servidor técnico-administrativo e cem estudantes distribuídos em dez equipes de trabalho. O intuito inicial era a formação de dez equipes de trabalho formadas por dez alunos, sendo um aluno de cada curso de licenciatura da Universidade. No entanto, por diversos problemas, só se formaram oito equipes, sendo que nem todas concluíram seus trabalhos, e as vagas para sua formação não foram preenchidas de acordo com a concepção original. Estas equipes tiveram três momentos de trabalho em ambientes diferentes: na UESC, em um bairro escolhido pelas equipes e em uma escola da rede pública. Nestes ambientes foram realizadas atividades relativas à identificação, apresentação e discussão de problemas ambientais e de acessibilidade detectados, e a apresentação de propostas de intervenção discutidas nos seminários integradores, que se realizaram ao final de cada etapa. 


\section{A PAISAGEM NO ESPaÇO DA VIDA}

A discussão sobre a paisagem não é exclusividade de nenhuma ciência; diversas delas trabalham este conceito, como a Biologia, a Ecologia, a Antropologia e a Arquitetura, mesmo que com enfoques teórico-metodológicos diferentes. Neste caso específico, a abordagem será geográfica, em que a paisagem é um momento da sociedade e as relações destas com o seu meio, seja ele natural ou cultural. A paisagem tem a sua expressão real, mas os sujeitos, de acordo com a idade, grau de escolaridade, gênero, profissão e com a história de sua existência, enxergam-na de forma múltipla, mesmo que em algum momento haja certa similitude no que vêem. Afinal, vivemos em sociedade e precisamos nos comunicar.

Segundo Castro (2002), a paisagem é tudo que se vê; mas a forma como os sujeitos a representam ou o imaginário social é carregado de valores simbólicos. Assim, a forma como enxergamos a paisagem é dual, sendo, concomitantemente, real e representação do real. A relação dialética entre a paisagem real e simbólica contribui para que os sujeitos tenham ações diferenciadas diante da mesma paisagem. Uns podem enxergar, por exemplo, a ocupação irregular das áreas de encostas, o aterramento de nascentes, o desmatamento, como problemas ambientais que requerem ação para resolvê-los; outros podem ver nestas transformações da natureza um significado positivo, um domínio do homem sobre a natureza. Então, mesmo que a paisagem seja "tudo aquilo que nós vemos, o que nossa visão alcança, a percepção é sempre um processo seletivo de apreensão" (SANTOS, 1997, p. 61).

Daí a ideia inicial de se formar, no PRODOCÊNCIA, equipes com alunos de diferentes cursos, ou seja, alunos que enxergam na paisagem, de forma particular, os problemas ambientais e de acessibilidade em diferentes lugares. Contudo, percepção não é conhecimento, é sempre um processo seletivo de concepção que requer ultrapassar a paisagem para entender as diversas imbricações que esta compõe e, a partir daí, passar para uma ação mais reflexiva. "Nossa tarefa é a de ultrapassar a paisagem como aspecto, para chegar ao seu significado" (SANTOS, 1988, p. 62). Por isso, andar pela UESC e fotografá-la, no que diz respeito aos problemas ambientais e de alteridade, foi o primeiro passo. Após isto é que os alunos puderam escolher um dos problemas e se aprofundar em seu estudo. Por que é assim? O que faz com que seja assim? Desde quando é assim? Por quê? De quem é a responsabilidade? A quem interessa que seja assim? Estas são algumas perguntas referentes aos problemas identificados e escolhidos 
para investigação, para as quais nossos alunos tiveram que buscar a resposta ao longo do trabalho. Porque, segundo Santos (2002, p. 109):

\footnotetext{
Não existe dialética possível das formas enquanto formas. Nem a rigor entre paisagem e sociedade. A sociedade se geografiza através das formas, atribuindo-lhe uma função que vai mudando ao longo da história. O espaço é a síntese sempre provisória entre o conteúdo social e as formas espaciais. A contradição é entre sociedade e espaço.
}

Para que se compreenda a configuração do mundo, é necessário observá-lo a fim de que se estabeleça uma relação entre o observador e o observado. O meio ambiente, através de suas propriedades físicas, fornece as informações, e o observador, por meio de um sistema receptor visual, coleta essas informações, cujo registro lhe permite o conhecimento do mundo físico.

Os objetos percebidos têm significados, pois o mundo possui muitas classes de significados, as quais se vão multiplicando na medida em que avançamos em nossa jornada neste Planeta. Os significados interferem na percepção do espaço, selecionando ou modificando propriedades, tais como cor, tamanho e contorno dos objetos.

Levando-se em conta a percepção do ambiente na UESC e no bairro, a partir da observação dos componentes da equipe e do ambiente de uma escola pública por seus alunos, sob a supervisão da equipe em questão, foi possível elaborar o texto que se segue.

\section{A teoria E a PRÁtica No PRODOCÊNCIA}

UESC: meio ambiente (resíduos químicos) e acessibilidade

A equipe um (1), formada inicialmente por oito alunas, concluiu os trabalhos somente com duas, sendo ambas do curso de Licenciatura em Química, o que acabou influenciando na escolha sobre os problemas ambientais a serem enfocados. Assim, sobressaiu a questão dos resíduos de laboratórios, tais como os biológicos, químicos e radiativos que, quando descartados de forma inadequada, têm impacto negativo sobre o solo e os mananciais aquíferos, ocasionando problemas difíceis de serem resolvidos. Segundo a pesquisa feita pelas alunas, os resíduos perigosos, gerados numa 
Universidade, devem ser tratados com mecanismos seguros para a sua passivação ou deposição final, pois requerem um procedimento de descarte muito distinto daquele dado ao lixo doméstico. Daí a necessidade da tomada de consciência, tanto da comunidade interna quanto da externa à UESC, no que se refere ao tratamento dos resíduos do Laboratório de Química, objeto de observação da equipe.

O texto que segue abaixo é resultado das pesquisas e reflexões desenvolvidas pelas alunas durante o projeto, em 2007-2008.

Segundo Campos (2008), um resíduo químico é considerado de risco quando listado especificamente em publicações dos órgãos oficiais de controle, nacionais e internacionais, ou se ele se enquadra em uma das quatro características a seguir:

1. Resíduo que possa servir como fonte de ignição - um líquido que tenha o ponto de fulgor de menos que $140^{\circ} \mathrm{C}$. Um sólido capaz de causar fogo por fricção ou absorção de umidade ou que sofre mudanças químicas espontâneas que resultem em queima vigorosa e persistente.

2. Resíduos corrosivos - soluções aquosas de $\mathrm{pH}$ menor ou igual a 2 ou maior ou igual a 12,5 .

3. Resíduos reativos - soluções aquosas de materiais instáveis que sofram mudanças químicas violentas sem detonação, possam reagir violentamente com água formando misturas potencialmente explosivas ou que possam gerar gases perigosos ou possivelmente letais. Materiais detonantes ou explosivos também se incluem nesta classe.

4. Resíduos tóxicos - resíduos que contêm um dos seus componentes em concentrações iguais ou maiores que os valores das tabelas de concentração máxima de resíduos tóxicos.

Os resíduos químicos também podem ser classificados como resíduos de processo ou descarte de materiais químicos comerciais. Esta distinção é importante na rotulagem. Um resíduo de processo é aquele que, em virtude de algum uso, processo ou procedimento, não atende às especificações originais do fabricante. Exemplos: efluentes de colunas cromatográficas, produtos diluídos, misturas reacionais, papéis contaminados etc. Mesmo que um resíduo de laboratório não se enquadre em nenhuma destas classes ou esteja listado nas tabelas, deve haver regras específicas de descarte definidas no âmbito da própria instituição.

No caso dos resíduos químicos da UESC, no que se refere aos considerados hospitalares, saem do Campus através do serviço público da coleta de lixo hospitalar. Os resultantes de componentes químicos são administrados pela Gerência de Laboratórios (GERLAB), que os armazena 
em tonéis ou sacos plásticos para, em seguida, poderem tomar um destino adequado, mas ainda não há um local adequado para armazená-los. Por isso, até o ano de 2008 , ficavam num espaço externo ao prédio do laboratório, conforme se apreende nas FIGURAS 1 E 2.

FIGURA 1- Resíduos químicos armazenados no interior do Laboratório de Química da UESC

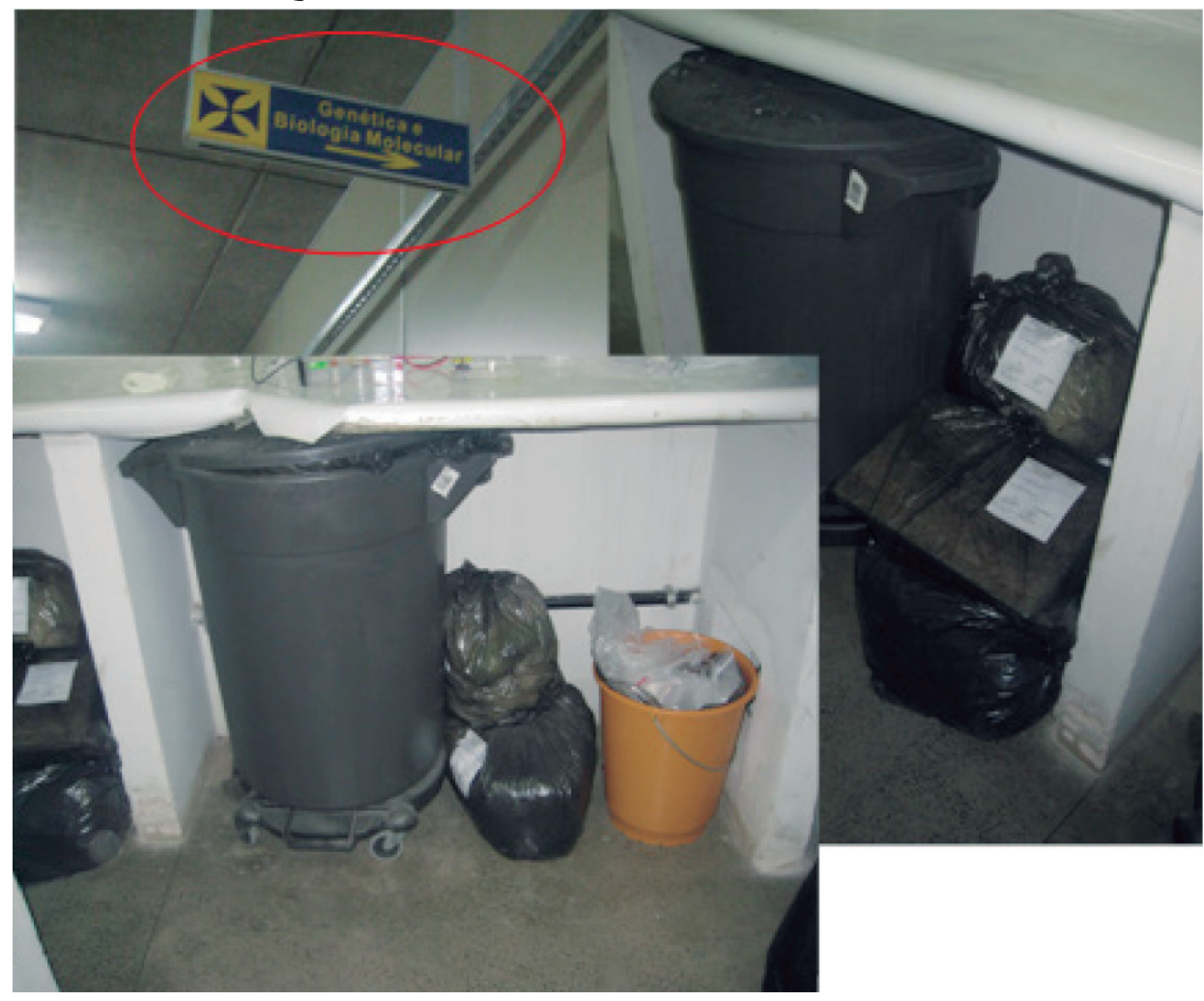

Fonte: Camila Carriço, 2006. 
FIGURA 2- Resíduos químicos armazenados no exterior do Laboratório de Química da UESC

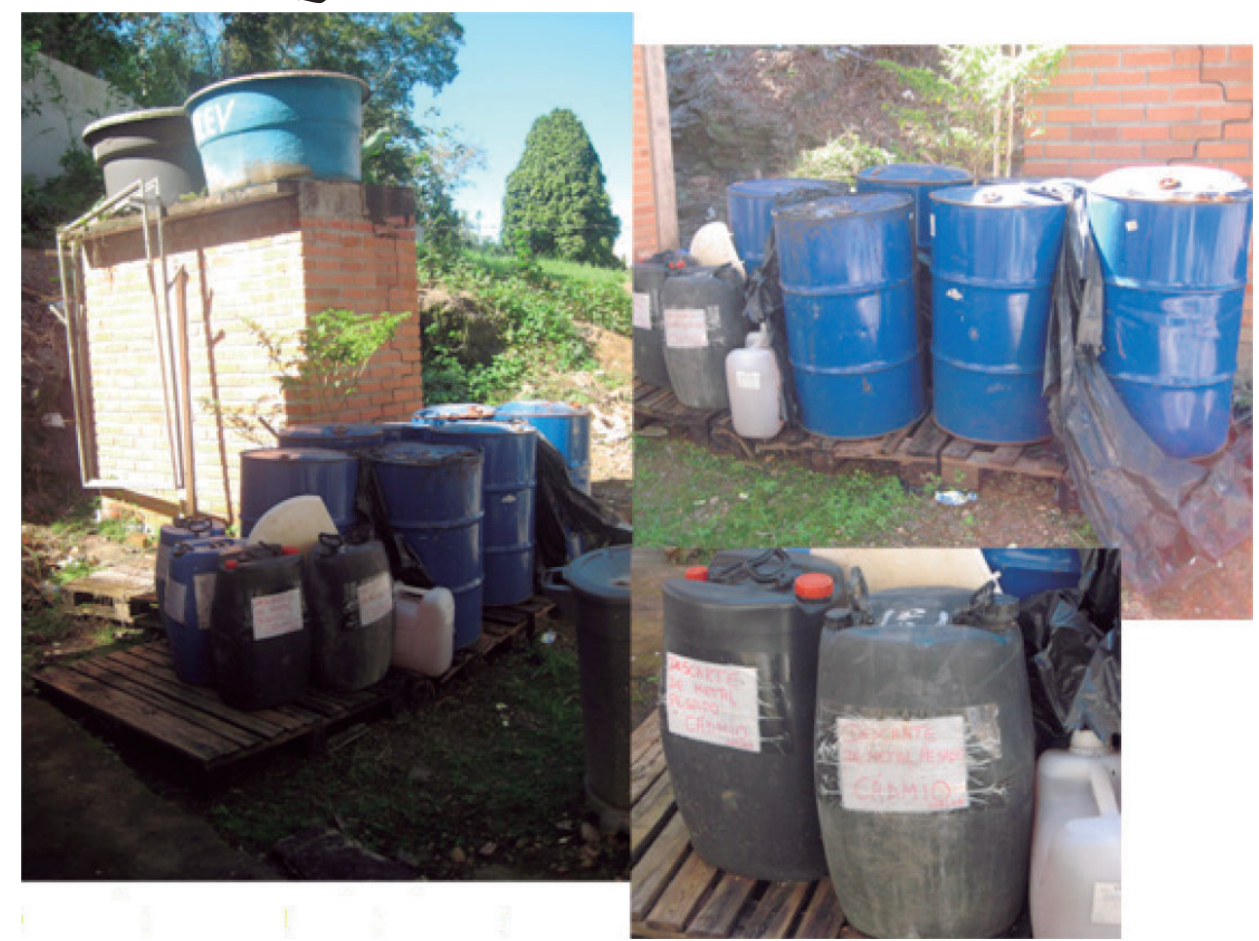

Fonte: Camila Carriço, 2006.

No momento em que esse trabalho foi desenvolvido, o armazenamento dos resíduos tóxicos, de maneira geral, ainda era um grande desafio devido à falta de estrutura para acolhê-los sem que agridam o meio ambiente, trazendo, como consequência, problemas de saúde aos humanos e aos animais, devido ao contato com as águas e os solos contaminados de alguma maneira. Portanto, as dificuldades com os resíduos químicos no Campus da UESC, devido à falta de estrutura física para armazenagem e equipamentos adequados para tratamento, não fogem à regra.

A equipe que observou como são tratados e armazenados os resíduos do Laboratório de Química da Universidade tinha que apresentar soluções para o problema identificado e, nesse sentido, sugere que: a) alunos e professores obrigatoriamente façam o curso de biossegurança para saber como lidar com os resíduos tóxicos; b) seja desencadeada uma campanha educativa ostensiva nos laboratórios quanto ao descarte dos resíduos; c) conste, no Regimento Interno da Universidade, medidas punitivas para alunos e professores que desczartarem indevidamente os resíduos tóxicos. 
A questão da acessibilidade ocupa cada vez mais espaço nas reflexões e nos debates, principalmente entre os educadores que denunciam as desigualdades sociais e as práticas excludentes. Quanto à acessibilidade na UESC, a Equipe um (1) observou, na época, as limitações do acesso entre os pavimentos dos pavilhões que compõem o conjunto de prédios da Universidade. Há algum tempo, foram instalados elevadores, mas, quase sempre estão com problema, por isso o acesso geralmente só se dá através de escadas que se tornam empecilho aos que têm alguma limitação permanente ou transitória para se locomover. A FIGURA 3 dá uma ideia do problema. Pela largura da escada, haveria possibilidade de dividi-la ao meio, transformando uma das metades em rampa, já que nem sempre o elevador está disponível ou funcionando.

FIGURA 3 - Escada entre os pavimentos de um dos pavilhões da UESC

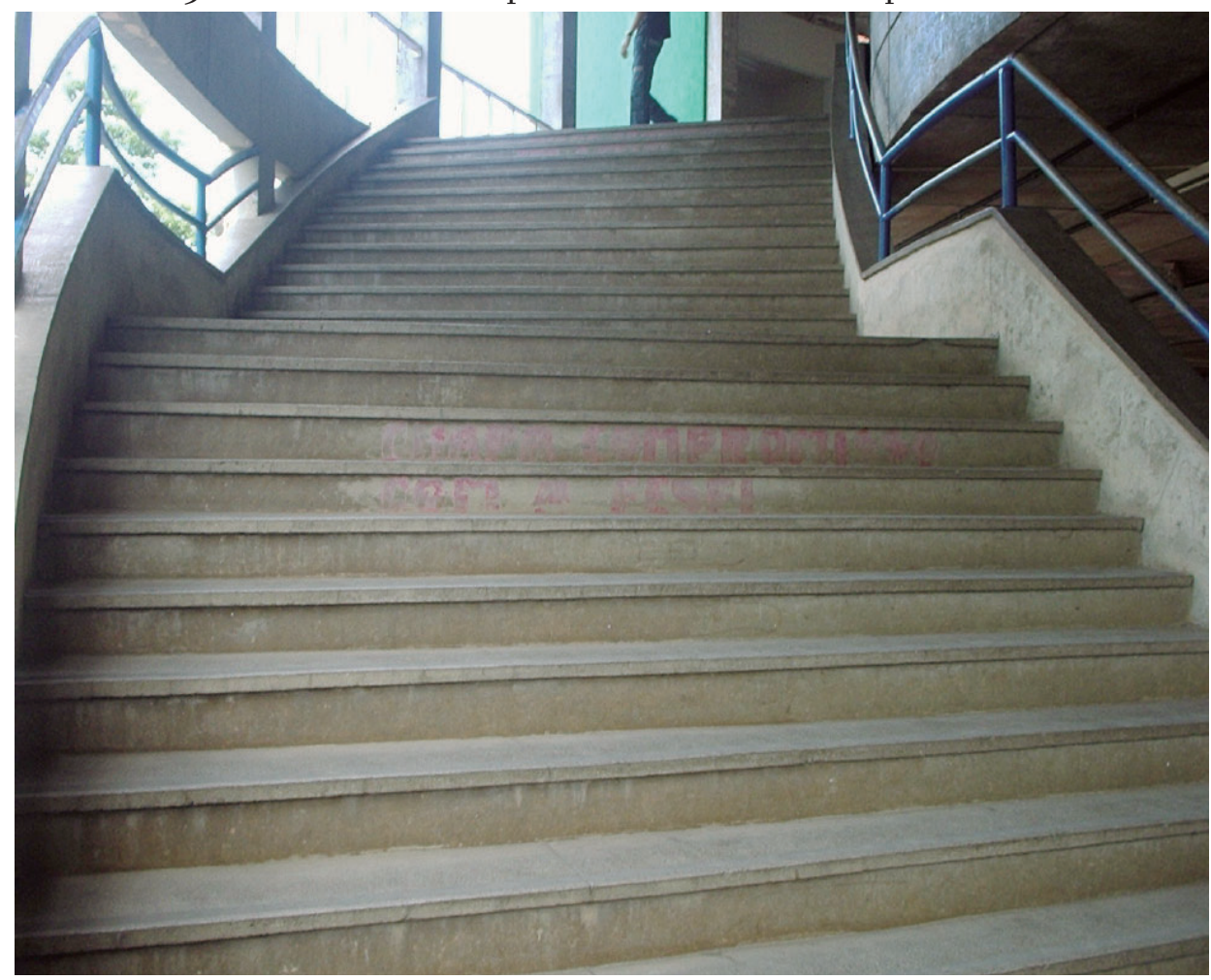

Fonte: Alane Braz, 2008.

\footnotetext{
Este problema já foi sanado. Nas escadas que ligam os pavimentos dos pavilhões foram colocados corrimões, melhorando a acessibilidade. A escada em referência é muito íngreme, não sendo possível ser essa a solução para o problema de acesso entre os pavimentos, entretanto, mantivemos a proposta aqui, pois foi o que as alunas do curso de licenciatura em Química, puderam apontar como solução.
} 


\section{BAIRRO: MEIO AMBIENTE E ACESSIBILIDADE}

O bairro escolhido pela equipe foi o Salobrinho (Ilhéus), cortado pela BR 415, onde está inserida a UESC, distante 16 quilômetros da cidade de Ilhéus e 12 de Itabuna (FIGURA 4). É perceptível que o mapa escolhido pela Equipe um (1) não fornece os elementos cartográficos de identificação do bairro Salobrinho, demonstrando a necessidade de um aluno da licenciatura em Geografia na equipe, que seria interdisciplinar.

FIGURA 4 - Localização do bairro Salobrinho, no município de Ilhéus, junto à BR 415

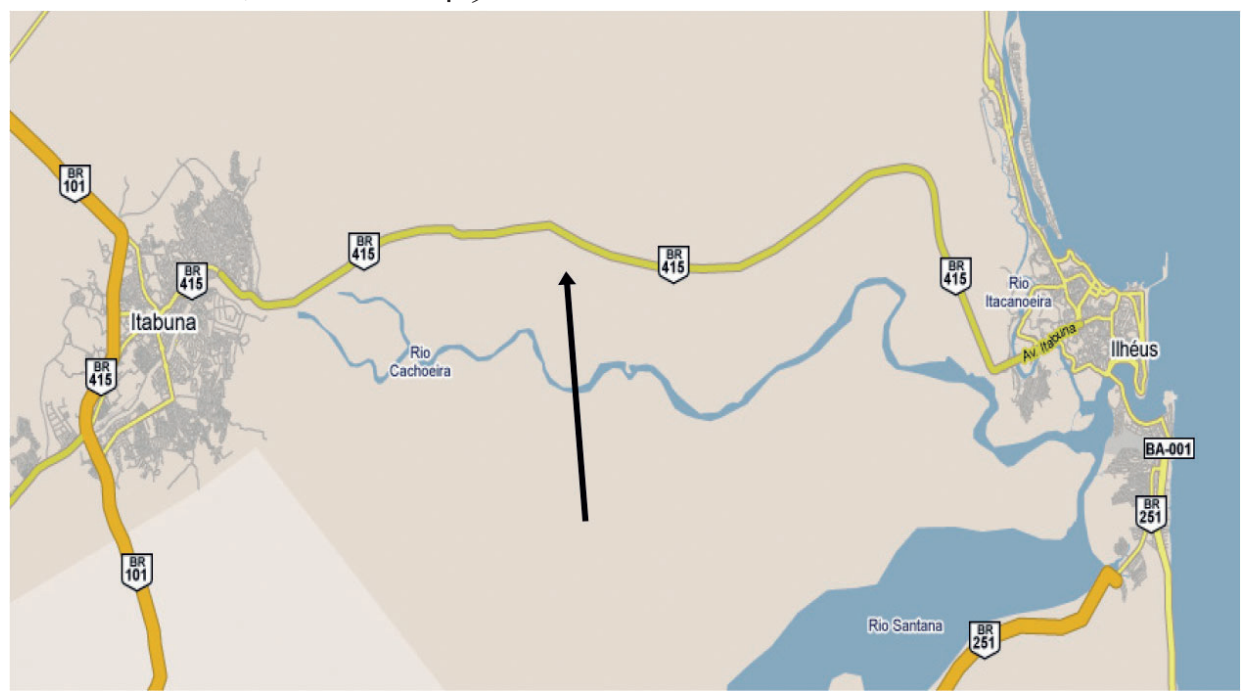

Fonte: Google Maps, 2006.

Dentre os vários problemas relacionados ao meio ambiente no bairro Salobrinho foram destacados os que mais chamaram a atenção da equipe, registrados nas FIGURAS 5, 6, 7 e 8. Esses problemas se relacionam, principalmente, ao lixo espalhado pelas ruas e calçadas, dando à paisagem um aspecto desagradável, mas, principalmente, poluindo e, consequentemente, sendo vetor de várias doenças.

Quanto à acessibilidade, logo na entrada do bairro Salobrinho, à margem da BR 415, no ponto onde os ônibus urbanos param, o acesso é feito por escada (FIGURA 7), dificultando a movimentação de pessoas idosas ou portadoras de qualquer limitação quanto à locomoção. Há outros acessos próximos, porém, são ruas sem calçada e com circulação de carros que vêm da rodovia. 
FIGURA 5 - Lixo por toda parte no bairro Salobrinho, Ilhéus

\section{MEIO AMBIENTE}

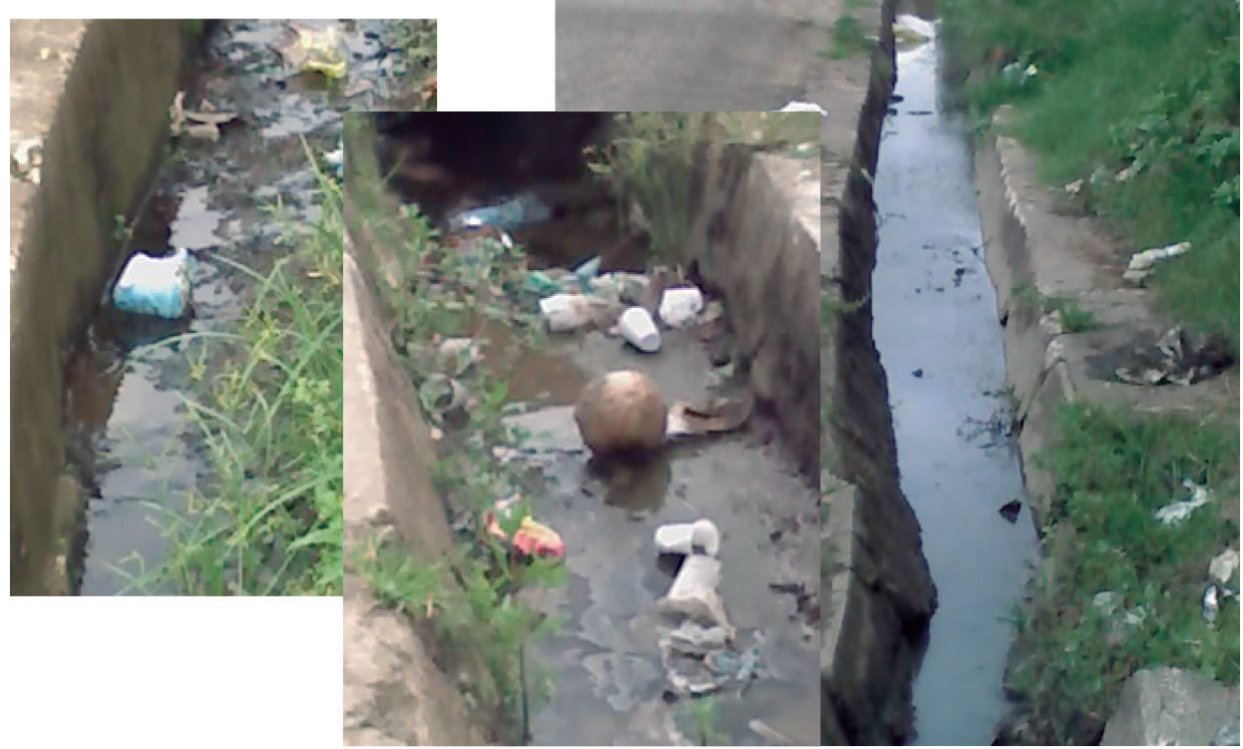

Fonte: Camila Carriço e Karen de Jesus, 2008.

FIGURA 6 - Mais lixo no Salobrinho...

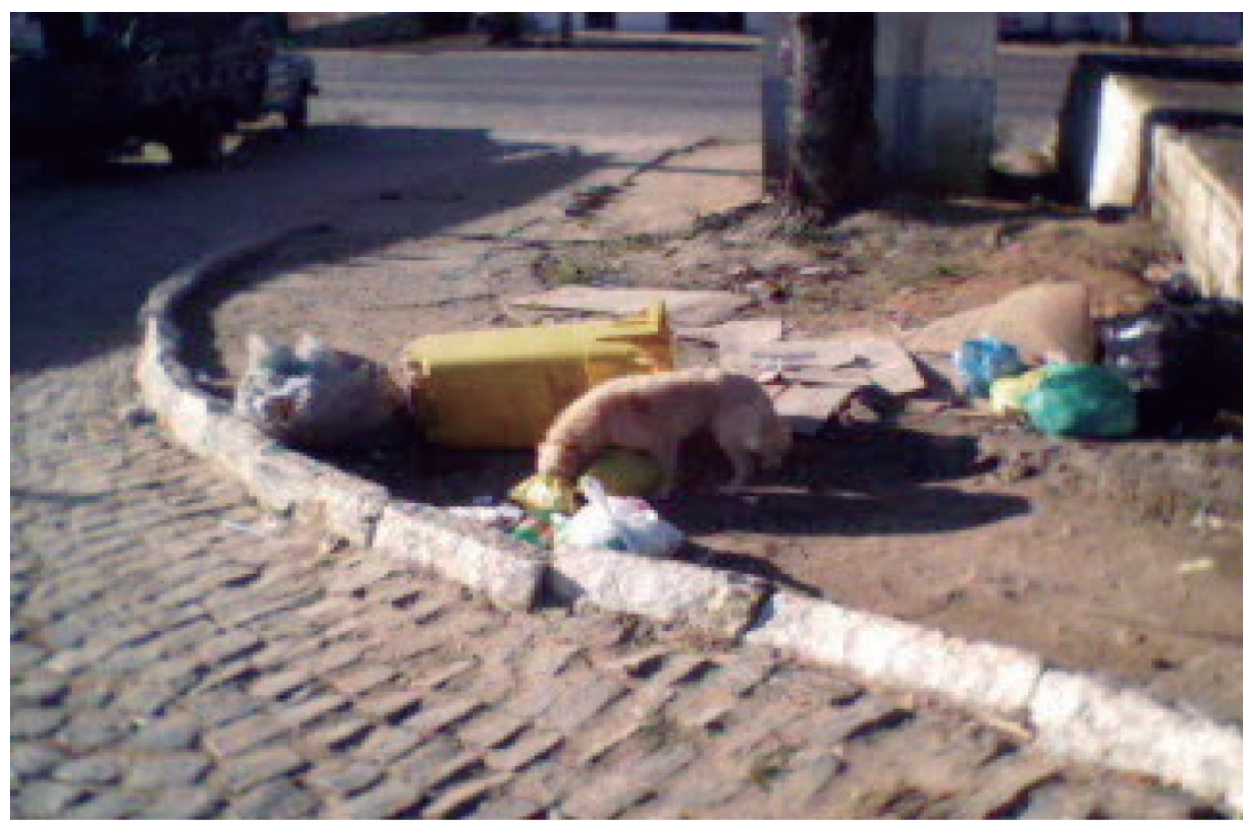

Fonte: Camila Carriço e Karen de Jesus, 2008. 
FIGURA 7 - Escadas de acesso da BR 415 ao bairro Salobrinho

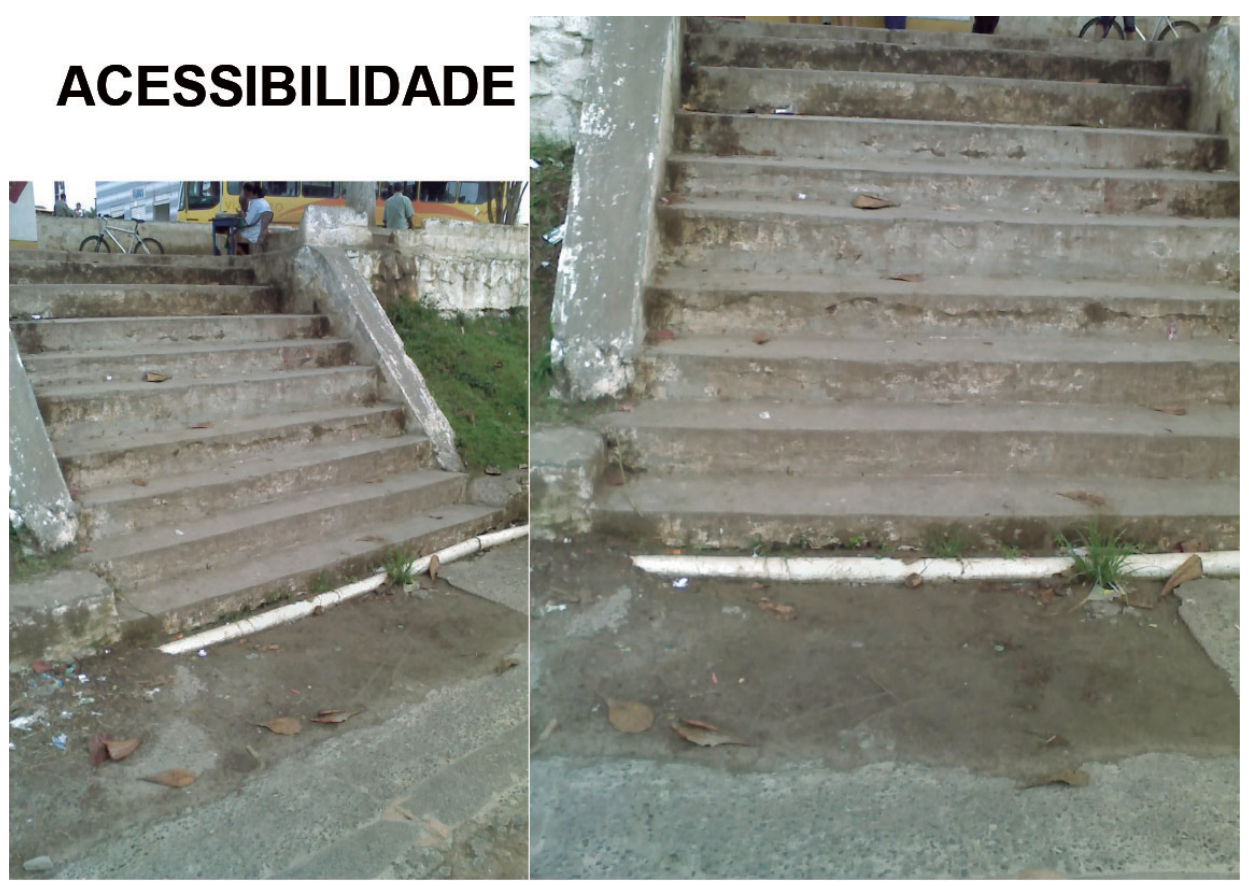

Fonte: Camila Carriço e Karen de Jesus, 2008.

FIGURA 8 - Mais dificuldades no acesso ao bairro Salobrinho

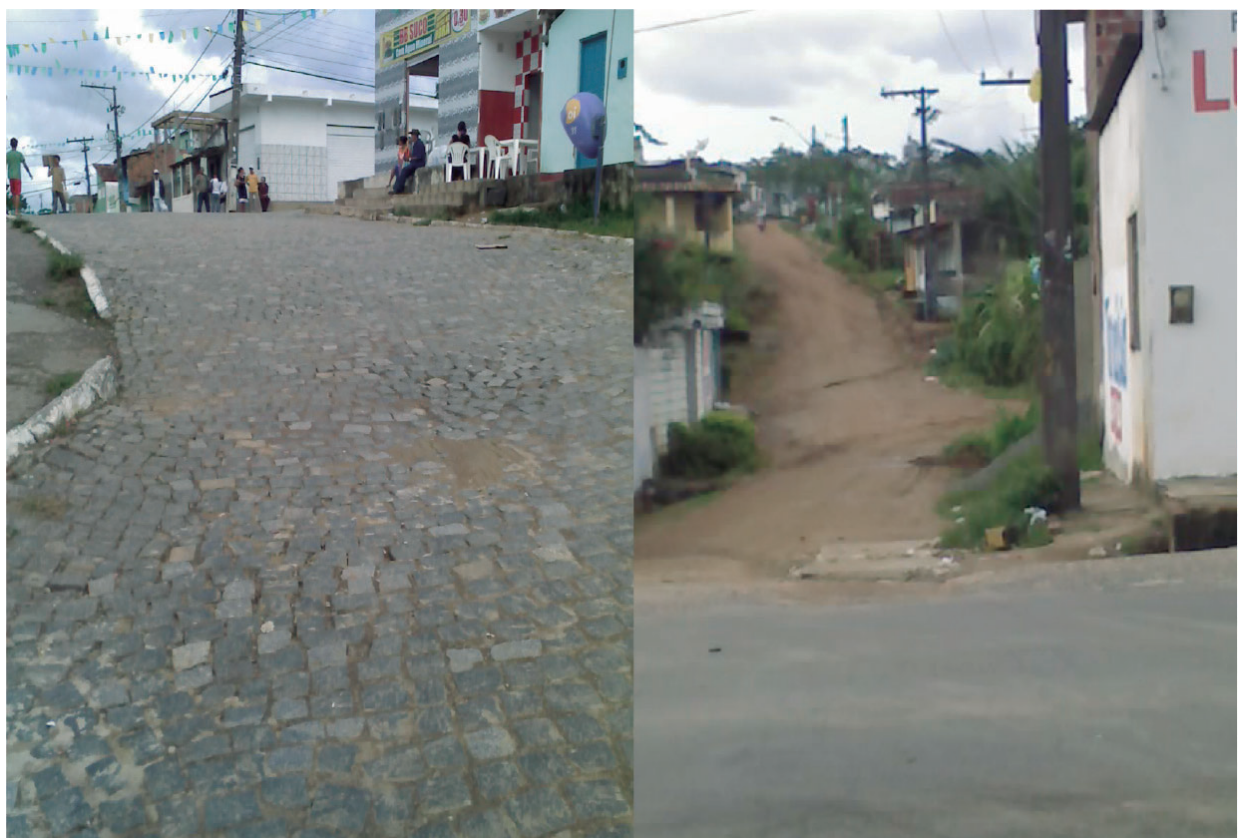

Fonte: Camila Carriço e Karen de Jesus, 2008. 


\section{ESCOLA}

Os membros da equipe um (1) escolheram uma turma do ensino fundamental I, de uma escola pública do bairro do Salobrinho, para aplicar as atividades de observação que desenvolveram nos dois momentos anteriores, ou seja, na UESC e no bairro. A terceira etapa do projeto tinha como objetivos despertar nos alunos da escola a observação e percepção do seu entorno quanto às questões ambientais e de acessibilidade para, como futuros cidadãos atuantes na comunidade, serem capazes de interferir, a fim de melhorar as condições de vida da população. Para isso adotaram a seguinte metodologia:

- Divisão da turma.

- Saída a campo para identificação dos problemas.

- Registro das paisagens através de fotografias.

- Escolha das fotografias de maior representação dos problemas.

- Apresentação das fotografias e discussão.

- Propostas de resolução dos problemas.

$\mathrm{Na}$ escola em questão, os alunos detectaram um problema que antes não tinham percebido: o acesso do térreo para o primeiro pavimento é feito por escada, restringindo, assim, o acesso de crianças com dificuldades de locomoção. Esse fato vai contra as normas de acessibilidade universal

considerando acessos a salas, áreas de serviço, cozinha, banheiros, áreas de brincadeira interna e externa, dentre outros espaços, de acordo com as normas brasileiras e os decretos em vigor (BRASIL, 2006, p. 16).

Outro problema levantado pelas crianças foi a questão da limpeza, principalmente dos banheiros e das paredes, que deixa a desejar. Depois de discutirem o assunto, fizeram as propostas de intervenção que se seguem:

- Organização e reforma dos espaços da escola com devidas adaptações.

- Projetos de conscientização.

- Horários de recreação alternados entre ensino fundamental I e II.

- Para se ter uma visão panorâmica do que foi desenvolvido nas três etapas do projeto pela Equipe um (1), segue o QUADRO abaixo. 


\section{QUADRO - Resumo das etapas desenvolvidas pela equipe 1}

\begin{tabular}{|c|c|c|c|}
\hline $\begin{array}{l}\text { Etapas do } \\
\text { projeto }\end{array}$ & $\begin{array}{l}\text { Espaços } \\
\text { observados }\end{array}$ & Problemas detectados & $\begin{array}{l}\text { Propostas de ações de } \\
\text { intervenção }\end{array}$ \\
\hline \multirow[b]{2}{*}{$\mathrm{I}^{\mathrm{a}}$. etapa } & \multirow[b]{2}{*}{ UESC } & $\begin{array}{l}\text { Meio ambiente } \\
\text { Mau uso das lixeiras, lixo } \\
\text { sanitário aberto e mau } \\
\text { descarte dos resíduos quí- } \\
\text { micos. }\end{array}$ & $\begin{array}{l}\text { Coleta seletiva dos lixos, ca- } \\
\text { nalização do esgotamento } \\
\text { sanitário, estocagem do lixo } \\
\text { químico em locais adequa- } \\
\text { dos até seu transporte para } \\
\text { uma empresa de tratamento } \\
\text { e, sobretudo, a sensibilização } \\
\text { dos indivíduos envolvidos no } \\
\text { manuseio dos diversos lixos. }\end{array}$ \\
\hline & & $\begin{array}{l}\text { Acessibilidade } \\
\text { As escadas que servem de } \\
\text { acesso aos andares supe- } \\
\text { riores nos dois pavilhões } \\
\text { da UESC foram consi- } \\
\text { deradas como perigosas } \\
\text { para os indivíduos que a } \\
\text { utilizam, principalmente } \\
\text { àqueles que necessitam de } \\
\text { cuidados especiais. }\end{array}$ & $\begin{array}{l}\text { Instalação de corrimões no } \\
\text { centro das escadas e constru- } \\
\text { ção de rampas paralelas que } \\
\text { possam ser utilizadas por ca- } \\
\text { deirantes e outros com neces- } \\
\text { sidades especiais. }\end{array}$ \\
\hline \multirow[t]{2}{*}{ II $^{\mathrm{a}}$. Etapa } & \multirow[t]{2}{*}{ Salobrinho } & $\begin{array}{l}\text { Meio ambiente } \\
\text { Os moradores apontaram } \\
\text { o esgotamento sanitário } \\
\text { que percorre o bairro e a } \\
\text { rodovia 'a céu aberto', sem } \\
\text { qualquer tratamento, cau- } \\
\text { sando doenças de pele e } \\
\text { respiratórias, que atingem } \\
\text { principalmente as crianças } \\
\text { e os idosos e atrai animais } \\
\text { como, ratos e baratas. }\end{array}$ & $\begin{array}{l}\text { Tratamento prévio do esgo- } \\
\text { to e transporte adequado até } \\
\text { uma estação de tratamento. }\end{array}$ \\
\hline & & $\begin{array}{l}\text { Acessibilidade } \\
\text { A falta de asfaltamento } \\
\text { das ruas, cheias de bura- } \\
\text { cos, trazem transtorno aos } \\
\text { moradores, principalmen- } \\
\text { te aos com necessidades } \\
\text { especiais do bairro e ao } \\
\text { transporte público. }\end{array}$ & $\begin{array}{l}\text { Calçamento das ruas, calça- } \\
\text { das apropriadas, com locais } \\
\text { de acesso a cadeirantes, cons- } \\
\text { trução de uma rampa para } \\
\text { acesso ao bairro a partir da } \\
\text { BR-415 que dá acesso ao bair- } \\
\text { ro, construção de uma passa- } \\
\text { rela sobre a BR que divide o } \\
\text { bairro, prevenindo acidentes. }\end{array}$ \\
\hline
\end{tabular}

Fonte: Dados coletados pela equipe 1. 


\section{Conclusão}

O principal legado deste trabalho, desenvolvido dentro do "Projeto Identidade, alteridade e paisagem: educação pelo olhar" foi o despertar de uma nova percepção do ambiente em que se vive e, a partir dele sugerir e, principalmente, obter melhorias nesse espaço de vivência. E, também, a reflexão de que se não enxergarmos os problemas na paisagem, estes não existirão como problemas, o que dificulta a ação no sentido de resolvê-los. Portanto, de olho na paisagem!

Além disso ressaltamos que a decisão de publicar o resultado de uma prática de ensino, mesmo depois de tanto tempo de sua execução, foi contribuir com a disseminação da forma teórico-metodológica adotada e não uma preocupação com a fidedignidade dos problemas e soluções apresentados pela Equipe um (1), principalmente considerando que a equipe original seria formada por 10 alunos, 1 de cada licenciatura. 


\section{REFERÊNCIAS}

\section{AGÊNCIA NACIONAL DE VIGILÂNCIA SANITÁRIA}

(Anvisa). Resolução da Diretoria Colegiada (RDC) n. ${ }^{\circ}$ 306, de 7 de dezembro de 2004. Revoga a RDC 33/03 - Dispõe sobre o regulamento técnico para o gerenciamento de resíduos de serviços de saúde. [Regulação], Anvisa, Brasília, DF, 2004. Disponível em: <http://e-legis.anvisa.gov.br/leisref/public/ showAct.php?id =13554 . Acesso em: 23 jun. 2008.

BRASIL. Ministério da Educação. Secretaria de Educação Básica. Parâmetros básicos de infraestrutura para instituições de educação infantil: encarte 1. Brasília, DF: MEC: SEB, 2006.

CAMPOS, S. de. Resíduos de laboratório. Medicina Avançada, [S.l., [200-?]]. Disponível em: <http://www.drashirleydecampos.com.br/noticias/302>. Acesso em: 23 jun. 2008.

CASTRO, I. E. de. Paisagem e turismo: de estética, nostalgia e política. In: YÁZIGI, E. (org.). Paisagem e turismo. São Paulo: Contexto, 2002. (Coleção Turismo).

EMPRESA BRASILEIRA DE PESQUISA AGROPECUÁRIA (Embrapa, Pecuária Sudeste). Laboratórios de tratamento de resíduos químicos. [São Carlos, 200-?]. Disponível em: $<$ http://www.cppse.embrapa.br/o5opesquisa/laboratorio-de-tratamento-de-residuos-quimicos/>. Acesso em: 23 jun. 2008.

GRUPO GESTOR. Proposta para o gerenciamento de resíduos perigosos dos

laboratórios do campus da UEL. Universidade Estadual de Londrina, Londrina, [200-?]. Disponível em: <http://www.uel. br>. Acesso em: 20 jun. 2008. 
JARDIM, W. de F. Gerenciamento de resíduos químicos em laboratórios de ensino e pesquisa. Química Nova, Campinas -SP, v. 21, n. 5, 1998.

OLIVEIRA, L. de. Percepção da paisagem geográfica: Piaget, Gibson e Tuan. Geografia, Rio Claro, v. 25, n. 2, p. 5-22, ago. 2000.

SANTOS, M. Metamorfoses do espaço habitado. 5. ed. São Paulo: Hucitec, 1997.

. A natureza do espaço: técnica e tempo, razão e emoção. São Paulo: Edusp, 2002. 


\section{SEÇÃO III}

\section{ENSINO DE GEOGRAFA: DIMENSÕES PRÁTICAS PARA O COTIDIANO EM SALA DE AULA}

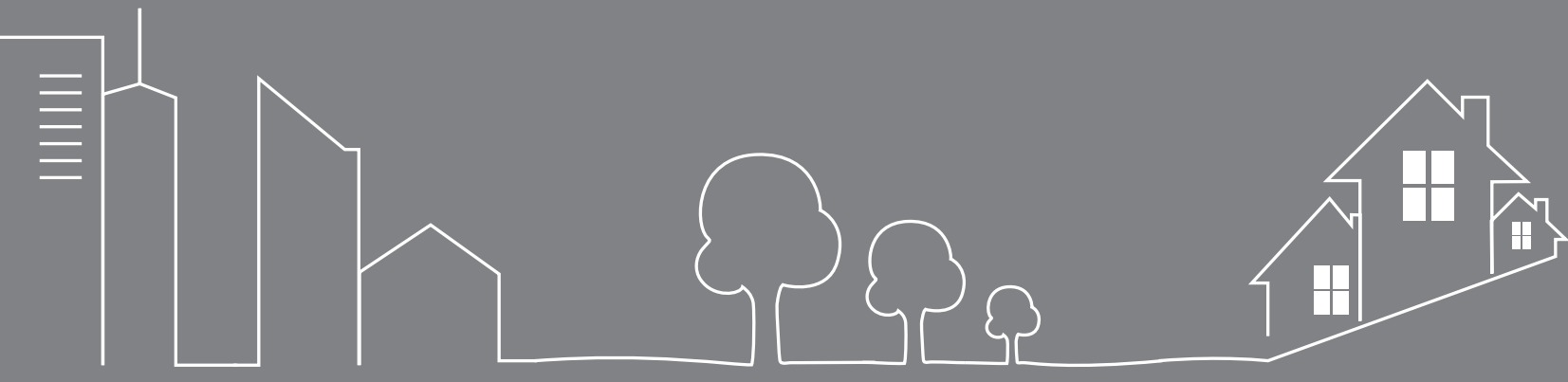




\section{O ENSINO DE GEOGRAFIA NA ESCOLA INDÍGENA: percebendo os olhares \\ Aderbal Pereira Santana Filho Rita Jaqueline Nogueira Chiapetti}

\section{INTRODUÇ̃̃o}

Quando eu pego um livro, porque por ser uma pessoa de um poder aquisitivo, eu sou da classe pobre, então eu não tenho condições de tá viajando, mas aí quando eu pego uma revista ou um livro que eu posso ver um pedacinho de cada local e eu me imagino naquele local, então isso para mim é fascinante, gratificante e se eu pudesse voltar ao tempo, eu teria estudado Geografia novamente (Professora Kawatá, 2013).

As comunidades indígenas possuem peculiaridades, próprias de povos tradicionais, e nelas se encontram instaladas escolas estaduais, com o objetivo de atender à demanda de alunos índios e não índios, objetivando construir uma educação pautada nos valores culturais e na formação cidadã de homens e mulheres que, inseridos na sociedade, possam contribuir para a edificação de um mundo melhor.

Nestas escolas espalhadas pelo Brasil, desde a Constituição Federal de 1988, os indígenas, enquanto grupo minoritário, têm se organizado procurando discutir um currículo único para atender aos interesses de seus povos. Este fenômeno abarca, dentre outras, a Escola Estadual da Aldeia Indígena Caramuru-Paraguaçu, aldeia dos povos Pataxó Hã-Hã-Hãi, localizada na região sul baiana, no perímetro rural do município de Pau Brasil.

Esta modalidade educacional, em que as escolas indígenas estão inseridas, referindo-se mais precisamente à Escola Estadual da Aldeia Indígena Caramuru-Paraguaçu, é amparada pela Lei de Diretrizes e Bases da Educação Nacional (LDBEN) (BRASIL, 2002), em função de atenderem às diversas exigências que as escolas não indígenas também cumprem. Contudo, são amparadas, também, pelo Referencial Curricular Nacional para as Escolas Indígenas (RCNEI) (BRASIL, 1998) que, dentre outras coisas, afirma que a educação escolar indígena se caracteriza por ser uma escola comunitária, intercultural, bilíngue, específica e diferenciada. 
Diante destes aspectos, investigar o olhar que professores de Geografia possuem a respeito de si, das suas práticas docentes e dos desafios encontrados, enquanto educadores indígenas, pode vir a ser elemento de grande importância para o entendimento de como é realizado o ensino de Geografia na escola indígena.

Por outro lado, os resultados encontrados nesta pesquisa poderão ser norteadores de outras discussões, inclusive visando à elaboração de materiais e ferramentas metodológicas, que poderão facilitar a capacitação dos professores indígenas no desenvolvimento de suas práticas docentes, garantindo uma educação de qualidade.

Além disso, a partir dos resultados desta pesquisa, pode-se estabelecer um diálogo entre os professores de Geografia da Escola Estadual da Aldeia Indígena Caramuru-Paraguaçu e as demais (indígenas e não indígenas), proporcionando uma troca de experiências com relação ao ensino de Geografia e à prática docente. Mas, para isso, torna-se necessário identificar o olhar, sobre o ensino de Geografia, de professores indígenas.

Para tanto, partiu-se do seguinte problema: Qual é a percepção dos professores indígenas da Escola Estadual da Aldeia Indígena Caramuru-Paraguaçu, de Pau-Brasil, sul da Bahia, acerca do ensino de Geografia, tomando por base sua prática docente e os avanços e desafios encontrados?

Na perspectiva de alcançar resposta ao problema da pesquisa, foram elaborados os seguintes objetivos: a) Geral: identificar a percepção dos professores indígenas que ensinam Geografia na Escola Estadual da Aldeia Indígena Caramuru-Paraguaçu, acerca desta disciplina e/ou área do conhecimento; b) Específicos:

1 - descrever a formação dos professores que ensinam Geografia nessa escola;

2 - identificar os conteúdos próprios e/ou principais temáticas do ensino de Geografia na escola em evidência, a partir do olhar desses professores;

3 - descrever os principais desafios e avanços percebidos na prática dos professores da referida escola, em relação ao ensino de Geografia, de acordo com seus próprios olhares.

A hipótese levantada é a de que os professores indígenas de Geografia, da Escola Estadual da Aldeia Indígena Caramuru-Paraguaçu, de Pau Brasil, desenvolvem suas práticas concatenados com as instruções apresentadas pelos Parâmetros Curriculares Nacionais (PCN) e, por isso, definem com segurança quais os temas e/ou conteúdos mais importantes para a aprendizagem geográfica de seus alunos. 


\section{Percebendo o SAber indígena}

O olhar é revelador, afinal, o mundo é desvendado através dele e, aos poucos, vai-se descortinando a imagem da paisagem, apresentando suas variadas faces e nuances. É como olhar o limite entre a noite e o dia, no qual a dança do universo possibilita, através da luz, perceber o espaço.

Se o olho, enquanto lente de visibilidade, permite às pessoas enxergarem, a percepção faz compreender o que está sendo visualizado. No entanto, mesmo com as pálpebras fechadas, às cegas, também é possível perceber através dos outros órgãos do sentido.

Este olhar também se encontra presente nas escolas indígenas e, por vezes, é confrontado por outros olhares. É maravilhoso pensar que a educação facilita diversos outros diálogos, surgidos através deles, os olhares.

Portanto, a educação, enquanto produção do saber, tem ocupado vastos debates em mesas redondas, seminários, conversas informais etc., caracterizando os diversos olhares, no que diz respeito aos enfoques teórico-metodológicos e às práticas pedagógicas. Este tema perpassa a história da humanidade e parece inesgotável, pois sempre são construídos novos argumentos, métodos ou metodologias, na tentativa de encontrar respostas que venham a sanar as deficiências percebidas no processo de ensino -aprendizagem.

Na pós-modernidade, apresentam-se outras discussões em torno da educação, próprias da contemporaneidade: continua-se buscando entender o processo de aprendizagem; investiga-se como o aluno aprende; mensuram-se as atividades que irão possibilitar maior aprofundamento das temáticas estudadas; discute-se a prática docente nas diversas esferas; proporciona-se o uso de novas ferramentas, como instrumentos que colaboram com a construção de novos saberes, e se apresenta uma educação voltada para grupos específicos, tentando atendê-los, respeitando as diferenças e valorizando a cultura local a partir do contexto étnico e identitário.

A história apresenta fatos que são marcantes quando o assunto é educação de povos tradicionais, em especial, os indígenas. Estes foram, ao longo do tempo, obrigados a frequentar as escolas tradicionais, tidas como dos "brancos". Este fenômeno legitimou, dentre outros fatores, a perda da língua, a fragmentação da cultura e o enfraquecimento identitário de diversos povos tradicionais.

Vale ressaltar que, nestas escolas, os indígenas eram obrigados a aprender o idioma falado pelos colonizadores, fato que, ideologicamente, os le- 
vava a pensar o mundo não mais como índios. Esta violência não declarada veio, conjuntamente com o capitalismo, promover outro olhar sobre os indígenas. Agora, não são mais aqueles "selvagens", "insolentes", dentre outros adjetivos pejorativos utilizados pelos colonizadores, nem tampouco massa de mão de obra barata a ser utilizada nas indústrias, mas, sim, "Um bando de preguiçosos que só quer terra, para ficar lá sem fazer nada" (frase muito comum de se ouvir). Em outros termos, os indígenas continuam recebendo qualificativos que os inferiorizam, pois, na verdade, seu modo de vida difere bastante daquele praticado pela sociedade urbana.

Em pleno final do século XX, eclode, no Brasil, o levante de diversos movimentos sociais que vão desde o rural até o urbano. Embaladas por estes ventos reivindicatórios, as comunidades indígenas também passam a exigir o direito de ter escolas em que os professores sejam indígenas, ensinando mediante o olhar que eles possuem da natureza e das relações sociais, políticas, econômicas e de mundo.

Esta proposta foi adotada por quase todas as comunidades indígenas rurais e urbanas, caracterizando escolas estaduais indígenas, as quais, na sua maioria, dividem a gestão entre um diretor indígena e outro não índio, travando um diálogo que proporciona, aos jovens índios, a oportunidade de estudar conforme os princípios de uma educação diferenciada, que valoriza os princípios básicos de povos tradicionais.

Portanto, o ensino de Geografia não pode ficar à margem desta discussão, uma vez que esta ciência trabalha, dentre outras, com as concepções de paisagem, território e lugar, conceitos que devem ser abordados a partir dos sujeitos que os praticam. Por conseguinte, identificar a percepção dos professores indígenas sobre suas práticas é de grande relevância para a construção do saber geográfico em escolas indígenas.

\section{FenOMenOlogia e PerCePÇÃo em GeOgrafia}

A escolha da percepção em Geografia, como abordagem metodológica, foi por conta de ser uma das tendências contemporâneas da Geografia que mais se aproxima do tema e do tipo de pesquisa. Ela

corresponde, portanto, a sistemas relacionais, nos quais é possível caracterizar as estruturas, não por decisões arbitrárias, mas procurando traduzir, passo-a-passo, em expressões precisas, as condutas dos sujeitos, das pessoas (OLIVEIRA, 2002, p. 190-191). 
Apresentar as inquietações dessa autora se torna importante, pois a mesma discute percepção, sujeito e objeto. Na Geografia, o tempo e o espaço são essencialmente importantes, e o que se verifica é, praticamente, um relato construído nos períodos iniciais do surgimento da Geografia Humanista. Daí por diante, muitos avanços aconteceram.

Dentre eles, os trabalhos de Tuan (1980) e Oliveira (2002), numa tentativa de fazer conhecer esta "outra forma de fazer Geografia", vêm proporcionando não só a formação de diversos professores que discutem esta temática em grupos de pesquisa por todo o Brasil, mas, principalmente, pelo volume crescente de trabalhos acadêmicos apresentados em congressos/seminários, como resultados de pesquisas realizadas por todo o território nacional.

Holzer (2008) afirma que, em meio aos processos de discussão, encontra-se uma Geografia Humanista que pensa, diferentemente do estruturalismo, do positivismo e do cartesianismo, procurando entender o mundo a partir da percepção que as pessoas possuem dele (mundo). E para dar conta deste universo em questão é que surge essa abordagem, denominada de Geografia Perceptiva ou percepção geográfica, que vem se desenvolvendo preocupada em "conhecer e em explicar as atitudes e os valores de uma comunidade frente ao meio ambiente" (XAVIER, 2005, p. 5), ou frente ao mundo.

Segundo Lencioni (2003, p. 150-151), "A consideração da percepção advinda das experiências vividas é, assim, considerada etapa metodológica importante e fundamental". Esta modalidade de pensar a Geografia e o mundo não se encontra nos contos de fada, mas se considera o mundo real, com toda a sua dicotomia e complexidade, possibilitando investigar o que o homem pensa, relatando o seu olhar perceptivo sobre a natureza, o espaço e o lugar de vivência.

É por isso que Tuan (1980), ao se referir à Geografia Perceptiva, admite que sua premissa não se encontra em priorizar a formulação de um conhecimento teórico e/ou objetivo, mas sim, que advenha das percepções, representações e valores dos homens. Essa Geografia pretende compreender o mundo através das inter-relações humanas, valorizando as ideias, o comportamento, o sentimento que os homens possuem, principalmente em relação aos lugares que habitam e aos outros homens.

A Geografia Humanista, na qual está inserida a percepção geográfica, representa "Um lento e progressivo despertar para o mundo" (FRÉMONT, 1980, p. 258), pois as coisas não estão apresentadas de forma clara, para que sejam compreendidas apenas dirigindo-lhes um olhar. É neces- 
sário desvendar o que não está aparente, fenômeno que pode acontecer a partir da fala do sujeito, da percepção que o mesmo possui do mundo. A percepção é, por conseguinte, responsável pela forma como se vê o mundo. Há tantos mundos quantas forem as percepções. Para Rocha (2003, p. 41), "É a percepção que vai determinar a forma do indivíduo ver, interpretar e interferir em seu meio".

Portanto, escolheu-se trabalhar com a abordagem metodológica denominada de percepção geográfica, como "outra forma de fazer ciência", pois foi a que mais se aproximou da temática e da pesquisa realizada.

Segundo Callai (2000, p. 84), "Compreender o lugar em que vive, permite ao sujeito conhecer a sua história e conseguir entender as coisas que ali acontecem", uma vez que este lugar se insere desde a escala local até a global, e o leva a compreender o mundo a partir do lugar de sua vivência.

O método mais adequado para esta pesquisa é, sem duvida, o fenomenológico, pois, conforme Merleau-Ponty (1999), a Fenomenologia está em busca da essência das coisas. Segundo esse mesmo autor, o palpável sempre existiu, contudo, o que é vivido vai sendo materializado e as experiências se tornam essenciais para o entendimento dos processos, ao passo que severas críticas são feitas pela filosofia ao empirismo, ao racionalismo e ao mundo contemporâneo, pois, "O pensamento moderno é difícil, inverte o senso comum porque tem a preocupação com a verdade, e a experiência não lhe permite mais ater-se honestamente às ideias claras ou simples" (MERLEAU-PONTY, 2004, p. 9-10).

Ao buscar, junto aos professores da Escola Estadual da Aldeia Indígena Caramuru-Paraguaçu, identificar sua percepção do ensino de Geografia, foi pertinente fazer uma análise qualitativa, pois Minayo (1994, p. 21-22), referindo-se a este tipo de pesquisa, afirma que:

ela trabalha com o universo de significados, motivos, aspirações, crenças, valores e atitudes, o que corresponde a um espaço mais profundo das relações, dos processos e dos fenômenos que não podem ser reduzidos à operacionalização de variáveis.

Corroborando com as ideias dessa autora quanto à análise qualitativa da pesquisa, a Fenomenologia passa a ter uma importância fundamental quanto ao método, pois " $E$ a tentativa de uma descrição direta de nossa experiência tal como ela é” (MERLEAU-PONTY, 1999, p. 1-2), uma vez que Fenomenologia e análise qualitativa caminham juntas. 
Para melhor desenvolvimento da pesquisa, optou-se por dividi-la em duas etapas:

$1^{a}$ etapa - Revisão teórica: levantamento e revisão bibliográfica em livros, artigos científicos, anais, relatórios de pesquisa, documentos etc. sobre Fenomenologia, percepção, prática pedagógica de professores indígenas e escolas indígenas.

$2^{a}$ etapa - Trabalho de campo: visita à Escola Estadual da Aldeia Indígena Caramuru-Paraguaçu, localizada no meio rural do município de Pau Brasil, no sul da Bahia, para explicar a pesquisa e obter autorização para desenvolvê-la e, em seguida, a realização da pesquisa de campo na referida escola.

O instrumento de coleta dos dados foi a entrevista semiestruturada, realizada com os dois únicos professores de Geografia da referida escola: Kawatá e Simiwawe (nomes indígenas pelos quais são conhecidos na aldeia).

O registro das entrevistas deu-se com o uso de um gravador, e as falas dos professores foram transcritas a fim de, posteriormente, serem utilizadas como dados da pesquisa.

\section{AraXá - LUGAR DE ONDE SE PODE VER O MUNDO}

Araxá, palavra de origem indígena do tronco Tupi que, segundo o Dicionário Ilustrado Tupi-guarani-pataxó (2013), traduzida, significa: “eça, ver, vista do mundo". Esta expressão traduz bem o pensar geográfico dos professores de Geografia da Escola Estadual da Aldeia Indígena Caramuru-Paraguaçu, já que eles possuem uma percepção de mundo que vai além do que a visão, propriamente dita, alcança. Também, pensar o ensino de Geografia é, necessariamente, ir além do olhar biológico. Ultrapassa o contexto teórico dos livros que, por vezes, trazem receitas, demonstrando como fazer acontecer uma aprendizagem eficiente.

Segundo Bergson (1999, p. 20), para que seja possível entender as coisas é necessário que: "Não digamos, portanto, que nossas percepções dependem simplesmente dos movimentos moleculares da massa cerebral". $\mathrm{Na}$ realidade, elas se agregam às outras tantas percepções apresentadas pelo mundo e, por isso, ensinar e aprender são fatores que não podem ser entendidos fora deste contexto. Esta "Percepção, tal como a entendemos, mede nossa ação possível sobre as coisas e por isso, inversamente, a ação possível das coisas sobre nós" (BERGSON, 1999, p. 58). 
$\mathrm{Na}$ verdade, esse autor está apresentando algumas abordagens que vão de encontro ao estruturalismo e ao realismo, quando o tema é a memória. Ele, através do estudo da percepção, caracteriza outras vertentes para o entendimento das coisas. Não bastam apenas o cérebro e as operações biológicas do corpo.

Nas escolas, por muito tempo, o que se privilegiava eram o saber matemático e a linguagem, para escrever bem, e não, necessariamente, para aprender a perceber o que não estava visível; era a escola pragmática e positivista. Estas concepções faziam-se presentes, também, na Geografia.

Ensinar Geografia era descrever a paisagem, decorar nomes de rios, de países, decalcar mapas e remontá-los em forma de quebra-cabeça, sem estabelecer nenhuma interação entre eles. Uma Geografia que não pensava a aprendizagem significativa, talvez por possuir um único olhar, não percebendo o que estava acontecendo em seu entorno, ou por causa dos variados interesses ideológicos.

Entretanto, o ensino de Geografia passou por diversas transformações, bem como a própria Geografia, enquanto ciência. Estas transformações provocaram diversos questionamentos, inclusive acerca dos aspectos reais que envolvem o saber e a aprendizagem, pois a realidade apresenta diversas possibilidades de interpretação, restando ao professor a tarefa de resgatá-las com seus alunos. De acordo com Chiapetti (2010, p. 144), entender "Como as pessoas vivem, também, em função de suas percepções, crenças, sentimentos e valores, suas visões de mundo têm sempre um sentido, um significado, que não são revelados de imediato, mas precisam ser desvelados"; e a escola tem este papel a desempenhar.

Baseado nessas diversas realidades, o olhar do professor de Geografia deve sempre buscar fotografar, com muita atenção, os fatos e as imagens presentes no seu cotidiano, exercitando a sua percepção. Conforme Chauí (2000, p. 154), a percepção:

É sempre uma experiência dotada de significação, isto é, o percebido é dotado de sentido e tem sentido em nossa história de vida, fazendo parte de nosso mundo e de nossas vivências $[. .$.$] , uma relação do sujeito com o mundo exterior$ [...], o mundo percebido é um mundo intercorporal, isto é, as relações se estabelecem entre nosso corpo, os corpos dos outros sujeitos e os corpos das coisas.

Conforme essa autora, parece ser impossível pensar o mundo separado da percepção, pois os sentidos colocam as pessoas diante do que veem, 
porém isto não é suficiente para fazer compreender a totalidade. Por isso é necessário uma Geografia que possa abarcar esta realidade.

$\mathrm{Na}$ verdade, a percepção geográfica não caracteriza o surgimento de uma nova Geografia, propriamente dita, mas, sim, outra maneira de pensar o mundo e o homem, uma vez que com o advento da industrialização e, posteriormente, a hegemonia do capitalismo, as concepções ideológicas constituídas se centralizaram, especificamente, em dois aspectos: mercadoria e consumo.

A partir desta observação, Claval (2002, p. 20), ao se referir ao enfoque funcionalista, sinaliza que "Essa geografia é uma ciência social, porém fala muito pouco dos homens", aspecto que, de certa forma, é rompido a partir do surgimento da Geografia Humanista.

Com relação ao professor de Geografia e à sua prática docente é imprescindível que o mesmo esteja consciente do papel a desempenhar neste mundo, pois "O geógrafo é uma testemunha do mundo: quando é convocado a depor, tem o direito e o dever de dizer o que viu e como viveu" (CLAVAL, 2002, p. 26). Ele deve estar, plenamente, com o seu olhar voltado para esta forma de fazer Geografia. Esse mesmo autor vai além, quando se refere à prática docente e a este "novo modo de fazer geografia", afirmando que:

A disciplina se liberta do peso que a oprimia. Ela fala do frescor do orvalho, da pureza de certos céus, do cheiro das fogueiras com lenha ou de esterco do qual é impossível escapar quando se percorre a planície do Ganges em dias ensolarados, no inverno. Ela faz descobrir o encantamento das paisagens da estação fria nos vales do norte de Hondo, onde as nevascas acontecem em um ambiente tão calmo (CLAVAL, 2002, p. 26).

$\mathrm{Na}$ escrita de Claval é possível perceber a existência de uma relação intensa e íntima entre quem observa e a paisagem observada. Este fenômeno também pode ser sentido por quem faz o percurso até a Escola Estadual da Aldeia Indígena Caramuru-Paraguaçu quando, ao se distanciar da cidade de Pau Brasil, pode observar a Mata Atlântica surgindo de forma exuberante, sendo possível sentir, através do olfato, o cheiro de terra molhada, de folhas e de galhos; o silêncio sendo quebrado pelo vento que faz galhos e folhas dançarem pelo som das águas correntes do rio Pardo, entrelaçando o território. Em meio a toda esta beleza, as figuras de índios homens e mulheres desta comunidade aproximam-se dos olhos do observador, compondo um quadro quase que harmônico, em que sociedade e natureza se interrelacionam, configurando um único corpo. 
A escola está ali presente e, em todo o seu entorno, a presença da Geografia. Esta, enquanto ciência, disciplina ou prática docente, está inserida nas diversas esferas da educação dos alunos índios, buscando compreender a diversidade existente, a partir da especificidade cultural e identitária indígena.

Por diversos motivos a educação indígena teve momentos de excessivo acanhamento, quase sem coragem para reclamar sua autonomia e seus direitos. A educação indígena não é a mão estendida à espera de uma esmola. É a mão cheia que oferece às nossas sociedades uma alteridade e uma diferença, que nós já perdemos. O ava haicha é uma fonte de inspiração, não uma simples condescendência para povos minoritários (MELIÁ, 1999, p. 16).

Essa autora chama a atenção para uma escola que, ao longo do tempo, esteve centralizada no indivíduo, não valorizando as múltiplas interações, sendo possível constatar este argumento através do tratamento que era dado aos alunos indígenas ou quilombolas das escolas do campo e até mesmo das áreas periféricas dos centros urbanos.

A educação indígena quer ocupar o espaço que é seu, não objetivando segregar a si ou aos outros, mas valorizar uma educação em que os signos e significados de seu povo e cultura sejam plenamente utilizados e percebidos, entranhados na prática docente, a fim de educar os seus mediante os saberes peculiares desta comunidade. Assim será construída uma educação pautada no respeito à diferença, o que pode produzir, nos alunos, uma tomada de consciência de que "Tudo o que vale para mim vale para o outro" (SARTRE, 1999, p. 454).

A sabedoria sartreana ensina a conviver com a diferença e aproxima aqueles que a história rejeitou ao longo do tempo, excluindo-os por questões étnicas, raciais e/ou sociais. Parece que a humanidade esteve cega, legitimando diversas atrocidades cometidas contra os povos indígenas do Brasil, desde o período colonial até os dias de hoje.

É esta atitude que denominaremos indiferença para com o outro. Trata-se, pois, de uma cegueira com relação aos outros [...]. Essas 'pessoas' são funções: o bilheteiro nada mais é que a função de coletar ingressos; o garçom nada mais é que a função de servir os fregueses [...]. Em tal estado de cegueira, ignoro concorrentemente a subjetividade absoluta do outro enquanto fundamento de meu ser-Em-si e de meu ser-Para-outro, em particular de meu 'corpo Para-outro' (SARTRE, 1999, p. 474, grifos do autor). 
A fim de reduzir as indiferenças, uma das decisões, após diversos conflitos entre os povos indígenas e o Estado Brasileiro, foi oficializar a instalação de escolas indígenas nos seus territórios, nas diversas modalidades: municipal, estadual e federal. Porém, ainda existe uma carência no que se refere ao Ensino Médio, pois em muitas comunidades esta modalidade não é oferecida.

$\mathrm{Na}$ Escola Estadual da Aldeia Indígena Caramuru-Paraguaçu estão matriculados 701 alunos indígenas, distribuídos em séries que vão do ensino fundamental I até a Educação de Jovens e Adultos (EJA), segundo dados secundários obtidos na secretaria da própria escola.

A escola em questão possui o total de 66 professores, em atuação profissional, com diversos estágios de formação: os que possuem apenas o ensino médio (o8), os que estão fazendo licenciatura (33), os que já concluíram a licenciatura (25) e, destes, alguns fizeram especialização. Com relação aos professores que já concluíram o ensino superior, eles fizeram licenciatura em várias áreas do conhecimento, como: Matemática, História, Letras, Pedagogia e Geografia. Vale ressaltar que alguns professores licenciados e, também, alguns não licenciados, já fizeram o Magistério Indígena e outros se encontram cursando.

O Magistério Indígena é uma modalidade de ensino oferecida por algumas universidades estaduais e pelo Instituto Federal da Bahia (IFBA), buscando contribuir com a formação do professor indígena a fim de capacitá-lo, não só em relação aos aspectos voltados para as questões pedagógicas, mas, principalmente, para a construção de uma escola diferenciada. Essa modalidade é de formação continuada e tem por objetivo formar os professores indígenas para o desenvolvimento de uma prática docente que possibilite o resgate, bem como a formação étnica e cultural dos alunos, valorizando os saberes populares e estimulando o uso da língua tradicional.

Neste universo:

\begin{abstract}
Apesar de haver muito escrito sobre educação escolar indígena e de uma espécie de consenso [...] sobre a "educação escolar intercultural, bilíngüe e diferenciada', proposta encampada pela política federal, sabemos muito pouco sobre quem está fazendo o quê nesse campo (SOUZA LIMA; BARROSO-HOFFMANN, 2007, p. 12, grifo do autor).
\end{abstract}

Com relação aos professores de Geografia da referida escola, eles também seguiram o mesmo trajeto dos demais em sua formação profissional, ou seja, fizeram licenciatura em Geografia e, agora, estão cursando 
o Magistério Indígena, uma garantia a mais para a educação voltada para a realidade indígena local, e dialogando com as demais escalas: regional, nacional e global.

Sobre o processo institucional que envolve a Escola Estadual da Aldeia Indígena Caramuru-Paraguaçu, desde o período de aldeamento em que os professores eram os próprios funcionários da Fundação Nacional do Índio (FUNAI) até a atualidade, essa escola passou por diversas transformações (QUADRO 1), devido ao próprio processo histórico. No princípio era uma escola indígena com somente professores não-índios. Mas hoje são os professores índios que ensinam a alunos indígenas da aldeia.

A partir de dados secundários informados pela secretaria da escola, verificamos que a mesma passou por diversos processos até se tornar uma instituição estadual de ensino, pois, conforme o QUADRO 1, ainda quando era somente o "Posto Caramuru-Paraguaçu", no período de 1982 a 1993 (aldeia que agregava diversas etnias), a formação dos alunos indígenas era realizada através de aulas ministradas pelos funcionários da FUNAI (a grande maioria antropólogos). Nesta época era uma escola, em território indígena, que seguia a orientação das escolas não indígenas ou convencionais, não havendo grande diferença, exceto que a escola estava localizada no espaço rural, possibilitando a formação escolar das crianças da aldeia.

QUADRO 1 - Processo de oficialização da Escola Estadual da Aldeia Indígena Caramuru- Paraguaçu: entidade mantenedora, período e modalidade

\begin{tabular}{|l|l|l|}
\hline Entidade Mantenedora & Período & Modalidade \\
\hline $\begin{array}{l}\text { Governo Federal -- } \\
\text { Funcionários da FUNAI }\end{array}$ & $1982-1993$ & Educação Infantil e Fundamental I \\
\hline Município de Pau Brasil & 1994-1999 & Educação Infantil e Fundamental I \\
\hline $\begin{array}{l}\text { Estado da Bahia -- SEC/ } \\
\text { DIREC 7 }\end{array}$ & A partir de 2000 & Educação Infantil e Fundamental I e II \\
\hline $\begin{array}{l}\text { Estado da Bahia -- SEC/ } \\
\text { DIREC 7 }\end{array}$ & A partir de 2005 & Educação Infantil até o Ensino Médio \\
\hline
\end{tabular}

Fonte: Dados fornecidos pela escola em nov. 2013.

Nota: Elaboração de Aderbal P. Santana Filho. 
Neste período, os alunos que completavam o ensino fundamental I passavam a frequentar a escola regular na cidade de Pau Brasil, indo e voltando para a aldeia, lugar de vivência de seu povo. Essa era uma época em que a escola convencional não abria espaço para a pluralidade, nem contemplava a etnicidade em seus conteúdos, muito menos as questões relacionadas às populações indígenas, visto o conflito sempre existente nesta localidade.

No período de 1994 a 1999 a Escola Estadual da Aldeia Indígena Caramuru-Paraguaçu passou a ser mantida pelo município de Pau Brasil, sob o comando da Secretaria Municipal de Educação, com as mesmas séries que já estavam instituídas.

A partir do ano de 2000 , findando o século XX, a escola passou a ser mantida pela Secretaria de Educação do Estado da Bahia, sob a atenção da DIREC 7 de Itabuna-BA, encontrando-se assim até o período atual. Desde então foi ampliada a seriação, constituindo a modalidade do ensino fundamental II e a partir de 2005 o ciclo completo, com a introdução do ensino médio.

Desta forma, os alunos indígenas não necessitaram mais se deslocar da aldeia em busca da educação escolar, visto que, na própria escola, já havia a possibilidade de conclusão do ensino fundamental e do médio. Este fenômeno estimulou e possibilitou que jovens indígenas ingressassem na licenciatura, indo para a universidade.

Importante afirmar que a Escola Estadual da Aldeia Indígena Caramuru-Paraguaçu está amplamente legitimada pela Constituição Federal Brasileira de 1988, e pela legislação relativa à educação comunitária, intercultural, bilíngue, específica e diferenciada, garantias percebidas durante o período da pesquisa.

Outro dado que deve ser considerado é o que Souza Lima e Barroso -Hoffmann (2007) apresentam com relação ao censo escolar nacional, o qual demonstra um crescimento linear em relação à formação acadêmica de professores indígenas na licenciatura, inclusive com pós-graduação lato e stricto sensu, ainda que em número reduzido. Nesse sentido, os professores da Escola Estadual Indígena da Aldeia Caramuru-Paraguaçu podem ser citados como exemplo desta realidade.

$\mathrm{O}$ retorno destes professores às suas comunidades caracteriza a importância fundamental da formação docente, bem como da aprendizagem dos alunos, podendo torná-los mais autônomos e conhecedores dos seus direitos enquanto cidadãos indígenas. 
Segundo Freire (2004, p. 23), quando, inicialmente, os índios tiveram acesso às escolas:

As línguas, a tradição oral, o saber e a arte dos povos indígenas foram discriminados e excluídos da sala de aula. A função da escola era fazer com que estudantes indígenas desaprendessem suas culturas e deixassem de ser indivíduos indígenas. Historicamente, a escola pode ter sido o instrumento de execução de uma política que contribuiu para a extinção de mais de mil línguas.

Se o passado, segundo o autor, não valorizou o ensino em sua pluralidade cultural e identitária, na atualidade não é verificado o mesmo. Conforme Ferreira (2001, p. 99):

\begin{abstract}
Queremos também que programas de educação sejam realizados pelos próprios índios e com materiais didáticos que falem sobre as nossas próprias realidades, não se esquecendo de ser uma educação bilíngue e que dê maior autonomia para as populações indígenas. Reivindicamos que o Governo Brasileiro nos dê condições para frequentarmos as universidades independentemente das normas exigidas pelo vestibular.
\end{abstract}

Segundo essa autora está bem claro o desejo da comunidade indígena quanto aos anseios de construir uma educação que garanta ao seu povo não só o contato com o saber, mas principalmente, o acesso às universidades. Esta conquista que vem acontecendo é fruto de muita luta, de derramamento de sangue e, principalmente, "Da iniciativa dos próprios povos indígenas, a partir da década de 80 , que decidem definir e autogerir os processos de educação formal" (FERREIRA, 2001, p. 72). Contudo, o cumprimento da lei vem acontecendo de forma muito lenta.

Com relação à Geografia, apesar de todas as abordagens constituídas, é salutar entender como a escola indígena trabalha essa disciplina, quais os temas mais importantes aos olhos dos professores e quais as limitações encontradas em sua prática docente. É obvio que pensar geograficamente deve ser um elemento de magnitude durante os planejamentos realizados pelos educadores.

É necessário perceber que, embora esteja se falando de uma escola indígena, os conhecimentos da ciência geográfica não podem ser descartados, nem tampouco colocados à margem ou em segundo plano. É, de todo, um olhar voltado para a aprendizagem, que procura construir saberes, proporcionando ao aluno indígena entender o mundo a partir de seus 
olhos, do lugar de vivência, conectado com o mundo. Fala-se, então, em diferentes escalas e redes de comunicação.

Muito embora as universidades formem milhares de profissionais a cada ano, muitos desses profissionais terminam as licenciaturas com sérias deficiências, sendo muito comum ouvir esses professores falando que aprenderam a docência, de fato, na lida, ou seja, na prática diária. Mas, nestas mesmas universidades o professor indígena está se formando e aprendendo que: "Quanto mais me dou à experiência de lidar sem medo, sem preconceito, com as diferenças, tanto melhor me conheço e construo meu perfil" (FREIRE, 1996, p. 134), perfazendo assim, o olhar sobre si mesmo, sua etnia, identidade e sua cultura.

\section{EmoÇão, LUTA E ENSINO de GeOGRAFIA}

Durante o percurso realizado para desenvolver esta pesquisa, contar com os professores indígenas foi essencial para alcançar seus objetivos. Após a entrevista realizada com eles, ou uma prazerosa conversa, houve entusiasmo em pensar esta Geografia Perceptiva, e continuar disseminando os saberes e as percepções desses professores. Na realidade, foi um desvendar do que a educação indígena tem a ensinar aos professores de Geografia das escolas não-indígenas ou convencionais.

A fim de facilitar a compreensão das entrevistas foi construído o QUADRO 2 com as respostas, evidenciando as percepções dos professores indígenas acerca de ensino de Geografia.

QUADRO 2 - Percepção dos professores indígenas quanto ao ensino de Geografia na Escola Estadual da Aldeia Indígena Caramuru-Paraguaçu

continua...

\begin{tabular}{|l|l|l|}
\hline $\begin{array}{l}\text { Temas das } \\
\text { questões da } \\
\text { entrevista }\end{array}$ & Professor 1 - Kawatá & Professor 2 - Simiwawe \\
\hline $\begin{array}{l}\text { Formação } \\
\text { acadêmica }\end{array}$ & $\begin{array}{l}\text { Licenciada em Geografia e Pedagogia } \\
\text { pela FTC/EAD e pós-graduanda em } \\
\text { psicopedagogia pela UNIVES. }\end{array}$ & $\begin{array}{l}\text { Magistério Indígena, Li- } \\
\text { cenciado em História pela } \\
\text { UNIME/Itabuna, gradu- } \\
\text { ando em Licenciatura In- } \\
\text { dígena pela UNEB. }\end{array}$ \\
\hline
\end{tabular}




\begin{tabular}{|c|c|c|}
\hline $\begin{array}{l}\text { Temas das } \\
\text { questões da } \\
\text { entrevista }\end{array}$ & Professor 1 - Kawatá & Professor 2 -Simiwawe \\
\hline $\begin{array}{l}\text { Percepção } \\
\text { de si }\end{array}$ & $\begin{array}{l}\text { "Logo no início eu não pensava nesse } \\
\text { processo do reconhecimento, porque } \\
\text { eu tinha meus parentes aqui, que é } \\
\text { parente de meu pai, eu não achava } \\
\text { que era necessário eu passar por uma } \\
\text { avaliação, pelos anciãos, pelos caci- } \\
\text { ques, pelas lideranças". }\end{array}$ & $\begin{array}{l}\text { Indígena nascido na aldeia } \\
\text { Caramuru, portanto, reco- } \\
\text { nhecido como índio. }\end{array}$ \\
\hline $\begin{array}{l}\text { Conhecimen- } \\
\text { to dos PCNs } \\
\text { de Geografia }\end{array}$ & $\begin{array}{l}\text { Tem conhecimento, adota-os em sua } \\
\text { prática pedagógica. }\end{array}$ & $\begin{array}{l}\text { Já leu e tem conhecimento, } \\
\text { mas disse: "a gente foge um } \\
\text { pouquinho para poder con- } \\
\text { templar a nossa realidade". }\end{array}$ \\
\hline $\begin{array}{l}\text { RCNEI como } \\
\text { norteador } \\
\text { para a prática } \\
\text { docente }\end{array}$ & $\begin{array}{l}\text { "Aqui a gente já tem o Referencial } \\
\text { Curricular Nacional para as Escolas } \\
\text { Indígenas, porque aqui é uma edu- } \\
\text { cação diferenciada [...] eu tenho que } \\
\text { trabalhar sim, a realidade indígena, } \\
\text { porém voltada também para os co- } \\
\text { nhecimentos da realidade não indíge- } \\
\text { na, porque esse aluno, ele tem que tá } \\
\text { apto quando ele sair daqui do ensino } \\
\text { médio, também para conviver com as } \\
\text { outras sociedades". }\end{array}$ & $\begin{array}{l}\text { Necessidade de adequação } \\
\text { entre a abordagem conven- } \\
\text { cional e indígena, uma vez } \\
\text { que os povos indígenas es- } \\
\text { tão na luta, reivindicando } \\
\text { "uma educação diferen- } \\
\text { ciada. É para realizar os } \\
\text { preceitos das comunidades } \\
\text { indígenas como um todo". }\end{array}$ \\
\hline $\begin{array}{l}\text { Percepção } \\
\text { que possui de } \\
\text { Geografia }\end{array}$ & $\begin{array}{l}\text { "Para mim, a Geografia é minha vida } \\
\text { (lágrimas nos olhos) }[\ldots] \text {, nem gosto } \\
\text { de tocar nesse assunto, porque fico } \\
\text { emocionada". }\end{array}$ & $\begin{array}{l}\text { "Geografia, pra mim, é } \\
\text { preservar o meio ambien- } \\
\text { te, é cuidar da natureza, } \\
\text { é cuidar dos rios, é cuidar } \\
\text { dos animais, é ter um co- } \\
\text { nhecimento sobre o Plane- } \\
\text { ta Terra". }\end{array}$ \\
\hline $\begin{array}{l}\text { Influência } \\
\text { exercida pelo } \\
\text { professor de } \\
\text { Geografia }\end{array}$ & $\begin{array}{l}\text { "Eu aprendi a gostar de Geografia } \\
\text { desde a } 6 \text { a série do ensino fundamen- } \\
\text { tal II, meu professor era Jorge Gomes. } \\
\text { Então, amava as aulas que ele dava } \\
\text { [...], ele chamava a atenção para a dis- } \\
\text { ciplina de Geografia". }\end{array}$ & Sem resposta. \\
\hline
\end{tabular}


continuação

\begin{tabular}{|c|c|c|}
\hline $\begin{array}{l}\text { Temas das } \\
\text { questões da } \\
\text { entrevista }\end{array}$ & Professor 1 - Kawatá & Professor 2 -Simiwawe \\
\hline $\begin{array}{l}\text { Comprome- } \\
\text { tendo o ensino } \\
\text { de Geografia }\end{array}$ & $\begin{array}{l}\text { Professores despreparados em sala de } \\
\text { aula, ensinando Geografia, pois "eu } \\
\text { percebo, também, que as escolas têm } \\
\text { uma grande culpa em relação a isso; } \\
\text { não falo da escola daqui, mas por onde } \\
\text { eu passei, a maioria das escolas pega } \\
\text { um professor iniciante para colocar pra } \\
\text { dar aula de Geografia". }\end{array}$ & Sem resposta. \\
\hline $\begin{array}{l}\text { Contribuição } \\
\text { do Ensino de } \\
\text { Geografia na } \\
\text { tomada de } \\
\text { consciência } \\
\text { dos alunos } \\
\text { indígenas e } \\
\text { não índios }\end{array}$ & $\begin{array}{l}\text { "Uma passagem de ônibus (referin- } \\
\text { do-se às manifestações de meados de } \\
\text { 2013) trouxe um leque de problemas } \\
\text { que estavam arquivados pelos políti- } \\
\text { cos, eles nem queriam tirar da gaveta } \\
\text { e aí uma passagem de ônibus fez com } \\
\text { que a população se sensibilizasse, tra- } \\
\text { zendo as questões que estavam lá no } \\
\text { seu íntimo, no seu eu. Então isso foi e } \\
\text { é de grande valia. Isso é devido à disci- } \\
\text { plina de Geografia". }\end{array}$ & $\begin{array}{l}\text { "Conscientizar os nossos } \\
\text { alunos para que preservem } \\
\text { o que ainda resta das matas, } \\
\text { para que no futuro próxi- } \\
\text { mo a gente possa ter um } \\
\text { aumento crescente dessa } \\
\text { vegetação [...] e nós den- } \\
\text { tro da temática indígena, } \\
\text { principalmente os povos } \\
\text { indígenas, a gente tem uma } \\
\text { preocupação de preservar e } \\
\text { restaurar aquilo que foi per- } \\
\text { dido durante muito tempo. } \\
\text { E, na Geografia, a gente tra- } \\
\text { balha muito isso". }\end{array}$ \\
\hline $\begin{array}{l}\text { Uso dos } \\
\text { conceitos da } \\
\text { análise geográ- } \\
\text { fica }\end{array}$ & $\begin{array}{l}\text { "Falo para os meus alunos: olhem, a } \\
\text { Geografia a gente tem que considerar } \\
\text { como a matéria-mãe pra nossa questão } \\
\text { interna, porque ela nos dá o suporte } \\
\text { da gente tá conhecendo as delimita- } \\
\text { ções do nosso território, o tamanho". }\end{array}$ & $\begin{array}{l}\text { Região: "a gente trabalha } \\
\text { tanto as questões geográfi- } \\
\text { cas da nossa região". } \\
\text { Território: "nós temos o } \\
\text { mapa da nossa aldeia que } \\
\text { atinge } 54 \text { mil hectares de } \\
\text { terra, que abrange os três } \\
\text { municípios e hoje esse } \\
\text { mapa é trabalhado na sala } \\
\text { de aula para que nossos } \\
\text { alunos saibam onde fica o } \\
\text { Ourinho, onde fica a Água } \\
\text { Vermelha, todas as regiões". }\end{array}$ \\
\hline
\end{tabular}


conclusão.

\begin{tabular}{|c|c|c|}
\hline $\begin{array}{l}\text { Temas das } \\
\text { questões da } \\
\text { entrevista }\end{array}$ & Professor 1 - Kawatá & Professor 2 -Simiwawe \\
\hline $\begin{array}{l}\text { Desafios } \\
\text { encontrados } \\
\text { no processo de } \\
\text { ensino-apren- } \\
\text { dizagem de } \\
\text { Geografia }\end{array}$ & $\begin{array}{l}\text { 1-Trabalhar com a Cartografia, uma vez } \\
\text { que o aluno nas séries iniciais não é al- } \\
\text { fabetizado cartograficamente e "chega } \\
\text { no ensino médio sem saber interpretar, } \\
\text { aí você tem que começar do zero, com } \\
\text { aquele aluno ali; esse é um desafio"; } \\
\text { 2- Dificuldade dos alunos quanto à in- } \\
\text { terpretação de texto; } \\
\text { 3- Professores de outras áreas ensinan- } \\
\text { do Geografia nas séries iniciais. }\end{array}$ & $\begin{array}{l}\text { Material específico que } \\
\text { atenda às escolas indíge- } \\
\text { nas, "porque nós não te- } \\
\text { mos material específico, } \\
\text { material produzido por nós } \\
\text { mesmos". }\end{array}$ \\
\hline $\begin{array}{l}\text { Principais } \\
\text { avanços } \\
\text { observados } \\
\text { em relação } \\
\text { ao ensino de } \\
\text { Geografia }\end{array}$ & $\begin{array}{l}\text { A importância do ensino de Geografia } \\
\text { como motivador para o surgimento do } \\
\text { movimento dos jovens, questionando } \\
\text { a sociedade na busca por melhores } \\
\text { condições urbanas e de acessibilida- } \\
\text { de, pois "pra trazer os problemas da } \\
\text { sociedade como a Geografia traz, não } \\
\text { vejo outra disciplina". }\end{array}$ & $\begin{array}{l}\text { 1-A escola indígena como } \\
\text { fortalecimento da cultura } \\
\text { e identidade; } \\
\text { 2-A promessa de concur- } \\
\text { so público específico para } \\
\text { professores indígenas do } \\
\text { estado da Bahia, a ser rea- } \\
\text { lizado em 2013-2014. }\end{array}$ \\
\hline $\begin{array}{l}\text { Correlacio- } \\
\text { nando os } \\
\text { conceitos geo- } \\
\text { gráficos com o } \\
\text { cotidiano }\end{array}$ & $\begin{array}{l}\text { "A gente tem que mostrar a aldeia } \\
\text { dentro do mapa onde ela está, por } \\
\text { mais que esse mapa seja uma visão eu- } \\
\text { ropeia, mas é o mapa que nos temos. } \\
\text { Então, se é o mapa que a gente tem, } \\
\text { a gente tem que trabalhar com ele". }\end{array}$ & $\begin{array}{l}\text { "Utilizamos a questão dos } \\
\text { rios, a hidrografia, quais são } \\
\text { os rios que têm na nossa al- } \\
\text { deia? Qual a utilidade des- } \\
\text { ses rios? Prá que servem? } \\
\text { Como prevenir, né? Pra po- } \\
\text { der esses rios não secar. O } \\
\text { que devemos fazer pra po- } \\
\text { der manter essa fonte viva } \\
\text { que é a questão da água?" }\end{array}$ \\
\hline $\begin{array}{l}\text { O ensino de } \\
\text { Geografia } \\
\text { incentivando } \\
\text { a formação de } \\
\text { alunos pesqui- } \\
\text { sadores }\end{array}$ & $\begin{array}{l}\text { "Fizemos entrevista dos alunos com } \\
\text { a Cacique Jéssica, o Cacique Nail- } \\
\text { ton, que eles têm a carta daqui do } \\
\text { território. Aí trouxeram a carta antiga. } \\
\text { Então, a carta que foi, disseram que } \\
\text { foi feita pelo povo da FUNAI, SPI, } \\
\text { porém, com a coordenação de alguns } \\
\text { indígenas, liderança daquela época. } \\
\text { Então, nós trabalhamos isso". }\end{array}$ & Sem resposta. \\
\hline $\begin{array}{l}\text { Utilização de } \\
\text { metodologias } \\
\text { e recursos } \\
\text { didáticos } \\
\end{array}$ & Uso de livros, mapas e revistas. & $\begin{array}{l}\text { "Na aula de campo traba- } \\
\text { lhava com vídeos, passando } \\
\text { vídeos para eles assistirem } \\
\text { e textos bibliográficos". }\end{array}$ \\
\hline
\end{tabular}

Fonte: Pesquisa de campo, Pau Brasil, Bahia, nov. 2013.

Nota: Elaboração de Aderbal P. Santana Filho. 
Conforme o QUADRO 2, durante as entrevistas, foi nítida a valorização que os professores atribuíram à disciplina de Geografia como veículo de sustentação da cultura e, principalmente, como elemento essencial na discussão sobre o território. Para eles, os Pataxós Hã-hã-hãi Caramuru-Paraguaçu, não menos do que os povos indígenas do Brasil, sabem muito bem o que representa a Terra, não só no sentido de preservação cultural, mas, principalmente, na integridade da vida. Eles estão vinculados diretamente ao território, quer seja em função da ancestralidade dos seus parentes que sempre viveram ali, e/ou por conta da necessidade de sobrevivência.

Por outro lado, esses professores entendem que a escola passa a ser este veículo de garantia de identidade, cultura e memória, elementos que não podem faltar nas aldeias indígenas, proporcionando ao aluno a compreensão da importância da Cartografia nesta abordagem, pois, segundo a professora Kawatá, "A gente tá mapeando, sabendo por onde passa [...], tem que mostrar a aldeia dentro do mapa onde ela está". Esta preocupação está enraizada na vida e na história deste povo indígena.

Paralelamente, segundo o professor Simiwawe,

O mapa, de certa forma, ele tem, ele traz uma informação e através daquela informação, o aluno, ele vai perceber a importância daquele mapa que tá sendo apresentado.

Esta feição que o mapa possui na vida dos povos indígenas tem a ver com a necessidade de comprovação, segundo a lei, de que ali estiveram os seus ancestrais e que, por isso, é necessário comprovar historicamente a presença deles neste território, a fim de legitimar uma Cartografia social, garantido a posse definitiva da terra.

Outro aspecto a ser destacado é com relação ao conhecimento do Referencial Curricular Nacional para as Escolas Indígenas (RCNEI), por parte dos professores entrevistados. O RCNEI representa, para os povos indígenas, não somente a conquista por espaços relacionados à terra, mas, também, no que se refere à Geografia, que:

[...] permite, assim, conhecer e explicar o mundo por meio do estudo do espaço geográfico levando em conta o que se vê - as paisagens; o que se sente e com que a pessoa se identifica - os lugares; e o que são referências significativas para os povos e os indivíduos, para conviver, trabalhar, e produzir sua cultura - os territórios (BRASIL, 1998, p. 214). 
$\mathrm{Na}$ realidade, o que isso apresenta com relação ao RCNEI é uma abordagem, que pode perfeitamente ser relacionada à Geografia Humanista, pois a todo o momento ele busca caracterizar a necessidade de produzir uma Geografia que esteja centrada na vida dos povos indígenas, partindo essencialmente do lugar de vivência do aluno.

O conceito de lugar, enquanto singularidade e espaço ao qual os indígenas estão vinculados pela ancestralidade, pela importância do território, pela relação existente com a Terra, com o sentimento que envolve esse povo e os lugares em que eles vivem, parece ter destaque no ensino de Geografia da Escola Estadual da Aldeia Indígena Caramuru-Paraguaçu.

Este lugar de vivência se torna de extrema importância, pois o aluno vinculado à escola traz vivência, histórias, pensamentos simbólicos e memórias para dentro das salas de aulas, e os professores de Geografia aproveitam esta gama de conhecimentos para, não só ensinar os temas e conceitos geográficos, mas também ressignificar os saberes, valorizando os aspectos marcantes, direcionando o que esta disciplina pode proporcionar a este povo.

Da vida de cada povo nasce uma geografia. Os alunos e alunas indígenas, como todos os outros, trazem para a escola seus conhecimentos geográficos. Esse conhecimento deve ser o ponto de partida e de chegada da geografia na escola. No caminho, há o diálogo entre o conhecimento geográfico do aluno e a geografia escolar não-indígena (BRASIL, 1998, p. 216).

Portanto, o RCNEI também tem como proposta:

formar os alunos e alunas como pesquisadores do seu povo, do seu tempo, do seu território e de outros territórios. Um dos caminhos que o professor pode percorrer junto com seus alunos, não só na área de geografia, é através de projetos de pesquisa. O aluno está envolvido em uma experiência educativa em que o processo de construção do conhecimento está integrado às práticas vividas. Num projeto, os alunos são corresponsáveis pelo trabalho e pelas escolhas ao longo do desenvolvimento da pesquisa (BRASIL, 1998, p. 232).

O RCNEI, dentre outros aspectos, supõe a necessidade de "construir" um aluno pesquisador, que consiga trazer para o seio da escola a história do seu povo e de seus ancestrais, fato verificado na entrevista do professor Simiwawe: 
A gente, às vezes, utiliza esse conhecimento através de entrevista com um parente da aldeia, um parente mais de idade [...], aproveita esse momento para tá lendo alguma coisa [...] de algum outro parente, de uma outra aldeia que já produziu alguma coisa.

Esta ação se vincula diretamente ao que propõe o RCNEI.

Este aluno, então, que estuda na escola indígena passa a resgatar a sua história a partir da coleta de informações dos ancestrais, procurando garantir a integridade cultural e linguística do seu povo. "Este é um olhar fenomenológico, um olhar de dentro, já que o sujeito da percepção faz parte do fenômeno" (CHIAPETTI, 2010, p. 141). Este olhar perceptivo aproxima a Geografia do povo indígena, caracterizando um momento de se ver, de se perceber, saber quem, de fato, é esse povo, o que ele pensa e quais são suas aspirações.

\section{Conclusão}

Algumas experiências marcarão eternamente as vidas daqueles que se deleitam em pensar uma educação plasmada nos saberes do homem, procurando entender quais os sentimentos que estão envolvidos no fazer geográfico.

Fazer Geografia é mais que estudar e ensinar conteúdos e temas, visto que este ensino coloca o homem como elemento importante, não só para o cuidado para com a Terra, mas principalmente pela condição de visualizar como parte deste "universo", não caracterizando superioridade, nem inferioridade, mas estando nos patamares de igualdade com todos os demais animais e plantas.

Os professores podem aprender a olhar o mundo e a natureza a partir desta percepção, ou seja, olhar com os olhos dos indígenas e entender o que representa para eles estar no mundo. Este aspecto poderia se transformar em um elemento de extrema importância para os professores de Geografia das escolas convencionais, visto que muitos deles ainda adotam a dicotomia entre sociedade e natureza.

No entanto, para muitos alunos indígenas esta compreensão associativa entre natureza e sociedade se inicia a partir da tradição oral, realizada dentro de casa, devido à importância que a natureza e a Terra têm para eles, perpetuando e tomando corpo nas salas de aula dessas escolas indígenas diferenciadas, espalhadas pelo Brasil afora. 
O olhar dos professores indígenas Pataxós Hã-hã-hãi Caramuru-Paraguaçu sobre o ensino de Geografia caracteriza preocupação e, ao mesmo tempo, reafirmação da sua identidade e cultura. Esta preocupação se dá no sentido do que eles percebem: que será necessário construir material específico de Geografia, que venha a atender estes alunos, a fim de fazer uma educação escolar pautada nos pilares da educação formal e indígena. E também que as escolas indígenas necessitam, dentre outros aspectos, de professores indígenas concursados, e que sejam colocados no mesmo nível dos demais professores da escola não-indígena. Esta é uma luta que está sendo travada entre as escolas indígenas e o governo do estado da Bahia.

Enquanto reafirmação, a escola indígena passa a ser um lugar de encontro, de agregação, de espaço aberto para toda a aldeia. Ali se encontra o ponto de unidade entre os povos que residem no lugar, pois os alunos aprendem a olhar o seu entorno e estudam a partir da realidade vivida por eles, trazendo a significação geográfica para a sala de aula, aproveitando a percepção que possuem do seu lugar.

Da mesma forma, os professores indígenas estão cientes da importância do ensino de Geografia para a manutenção identitária e cultural do seu povo, bem como para a resistência e luta pelo território, perpassando pelo estudo cartográfico, pelo uso dos mapas, fator de magnitude para os Pataxós Hã-hã-hãi Caramuru-Paraguaçu.

Com relação à hipótese citada nesta pesquisa, de analisar o olhar dos professores de Geografia da Escola Estadual Indígena da Aldeia Caramuru -Paraguaçu, eles afirmam que têm conhecimento dos PCN e que os utilizam em sua prática docente. No entanto, pontuam que, por vezes, distanciam-se deles a fim de trazer para as aulas questões específicas da educação indígena.

Perceber o olhar dos professores de Geografia da referida escola nos possibilitou compreender o que eles, de fato, pensam acerca do ensino da Geografia, pois ao serem interpelados souberam claramente dizer que para o seu povo, seja enquanto disciplina, área do conhecimento e/ou abordagem metodológica, a Geografia está entranhada/enraizada na história e na construção identitária e cultural dos indígenas.

Além disso, o ensino de Geografia se encontra a serviço dos outros saberes, fomentando a consciência crítica dos alunos, os quais percebem, segundo os professores envolvidos na pesquisa, que esta disciplina está em todos os lugares de suas vivências, bem como no entendimento do que é o território para eles. 
Os professores indígenas Pataxós Hã-hã-hãi Caramuru-Paraguaçu ensinam o quão necessário é a Geografia na construção dos saberes, quer seja no âmbito da aprendizagem significativa, ou para a afirmação identitária e cultural, para conquista dos direitos ou, mesmo, para tomarem consciência da importância da Terra, possibilitando construir novos olhares a partir do que é percebido por eles.

Por fim, um percurso como este adentra ainda mais nesta abordagem da percepção em Geografia, que consegue escutar a fala destes povos, entendendo a percepção que eles possuem das coisas, quais os olhares construídos ao longo da sua existência e, mais ainda, que lugar a Geografia ocupa na aldeia, na escola... em suas vidas. 


\section{REFERÊNCIAS}

BERGSON, H. Da sobrevivência das imagens. A memória e o espírito. In: ___ Matéria e memória: ensaios sobre a relação do corpo com o espírito. 2. ed. São Paulo: Martins Fontes, 1999.

BRASIL. Referencial Curricular Nacional para as Escolas Indígenas (RCNEI). Brasília, DF: MEC: SEF, 1998.

Parâmetros Curriculares Nacionais (PCNs): Ciências Humanas e suas tecnologias. Brasília, DF: MEC: SEMTEC, 2002.

CALLAI, H. C. Estudar o lugar para compreender o mundo. In: CASTROGIOVANNI, A. C. (org.). Ensino de Geografia: práticas e textualizações no cotidiano. Porto Alegre: Mediação, 2000.

CHAUÍ, M. Convite à Filosofia. São Paulo: Ática, 2000.

CHIAPETTI, R. J. N. Pesquisa de campo qualitativa: uma vivência em Geografia Humanista. GeoTextos, Salvador, v. 6, n. 2, p.139-162, dez. 2010.

CLAVAL, P. A revolução pós-funcionalista e as concepções atuais da Geografia. In: MENDONÇA, F.; KOZEL, S. Elementos de epistemologia da Geografia contemporânea. Curitiba: UFPR, 2002.

DICIONÁRIO ILUSTRADO TUPI-GUARANI-PATAXÓ. A origem de várias palavras da cultura brasileira. Brasília, DF, [21--?]. Disponível em: <http://dicionariotupiguarani.blogspot. com.br/2012/o7/a.html>. Acesso em: 23 nov. 2013. 
FERREIRA, M. K. L. A educação escolar indígena: um diagnóstico crítico da situação no Brasil. In: SILVA, A. L.; FERREIRA, M. K. L. (org.). Antropologia, História e Educação: a questão indígena. São Paulo: Global, 2001.

FREIRE, J. B. Rio Babel: a história das línguas na Amazônia. Rio de Janeiro: Atlântica, 2004.

FREIRE, P. Pedagogia da autonomia: saberes necessários à prática educativa. São Paulo: Paz e Terra, 1996.

FRÉMONT, A. A região, espaço vivido. Coimbra, Portugal: Almedina, 1980.

HOLZER, W. A Geografia Humanista: uma revisão. Espaço e Cultura, Rio de Janeiro, p. 137-147, 2008. Edição Comemorativa 1993-2008.

LENCIONI, S. Região e Geografia. São Paulo: EDUSP, 2003.

MELIÁ, B. Educação indígena na escola. Cadernos Cedes, Campinas, n. 49, p. 11-17, dez. 1999.

MERLEAU-PONTY, M. Fenomenologia da percepção. 2. ed. São Paulo: Martins Fontes, 1999.

Conversas - 1948. São Paulo: Martins Fontes, 2004.

MINAYO, M. C. de S. (org.). Pesquisa social: teoria método e criatividade. 17. ed. Petrópolis: Vozes, 1994.

OLIVEIRA, L. de. Ainda sobre percepção, cognição e representação em Geografia. In: MENDONÇA, F.; KOZEL, S. Elementos de epistemologia da Geografia. Curitiba: UFPR, 2002.

ROCHA, L. B. O centro da cidade de Itabuna: trajetória, signos e significados. Ilhéus: Editus, 2003. 
SARTRE, J.-P. O ser e o nada. 7. ed. Petrópolis: Vozes, 1999.

SOUZA LIMA, A. C. de; BARROSO-HOFFMAN, M. B.

Universidade e povos indígenas: desafios para uma educação superior universal e diferenciada de qualidade com o reconhecimento dos conhecimentos indígenas. In: SEMINÁRIO EM POLÍTICAS PÚBLICAS DE AÇÃO AFIRMATIVA E DIREITOS CULTURAIS DIFERENCIADOS, 2007, Rio de Janeiro. Anais... Rio de Janeiro: UFRJ: Museu Nacional: LACED, 2007. p. 5-32.

TUAN, Y-F. Topofilia: um estudo da percepção, atitudes e valores do meio ambiente. São Paulo: Difel, 1980.

XAVIER, H. Contribuições de Lívia de Oliveira para a percepção geográfica do turismo. In: SIMPÓSIO NACIONAL SOBRE GEOGRAFIA, PERCEPÇÃO E COGNIÇÃO DO MEIO AMBIENTE (SINPEC), 2005, Londrina. Anais... Londrina: UEL, 2005. 1 CD ROM. 


\section{O PORTO DE \\ SANTOS, VIVÊNCIAS, \\ PERCEPÇÕES E \\ SENTIMENTOS ALÉM \\ DOS MUROS DA \\ ESCOLA: um relato de \\ esperiência e prática}

\section{Gilsélia Lemos Moreira}

\section{CONSIDERAÇÕES INICIAIS}

Existe um fosso que separa professor e aluno, e os muros da escola não são os únicos que revelam essa separação entre os dois lados. Há também outros muros invisíveis. Temos uma tensão entre, de um lado, a escola com suas formas historicamente construídas, suas infraestruturas, enfim, construída sobre os auspícios de sistema educacional, arcaico e colonizador.

Ao longo dos séculos construímos uma escola repleta de símbolos e significados, mas que não orienta a ação dos indivíduos na direção dos valores éticos e pleno exercício da cidadania. Por outro lado, há a visão dos alunos como indivíduos, ou melhor, jovens que afirmam não encontrar nada de significativo e interessante na escola.

A escola pouco reconhece as relações e interações como práticas sociais que envolvem processos educativos legítimos. Essas relações deveriam acontecer a partir de reflexões sobre o cotidiano, esse seria um caminho possível na formação de alunos capazes de agir com criticidade, responsabilidade e ética.

Os professores podem contribuir, mas a escola tem que reestruturar conteúdos, encontrar formas de reconhecer o potencial dos jovens, e adotar práticas educativas que estimulem a participação dos alunos no cotidiano escolar. A escola deve ir ao encontro das aspirações dos jovens estudantes.

Sendo assim, para não divagar e perder a epígrafe deste alento tempestivo se faz necessário, recuperar o papel socializador da escola, conceber a 
juventude em sua multiplicidade, bem como, dar nova ênfase às políticas públicas educacionais e redesenhar o espaço escolar.

Um caminho possível está no interior da própria escola, o que implica problematizá-la no contexto de um mundo globalizado. Uma escola que pretende inovar e ampliar a sua prática educativa, deve proporcionar aos seus alunos, espaços para discutir a realidade, a fim de avaliá-la, ressignificá-la e finalmente transformá-la. Estimular os alunos a participar de atividades extracurriculares de cunho interativo/educativo pode ser um importante passo nessa direção. Esse caminho nos propõe como horizonte a articulação entre teoria e prática.

A partir daqui, vamos apresentar um relato de experiência e prática com alunos do ensino médio de uma escola da rede privada da cidade de Santos- SP. Estes alunos participaram de um concurso promovido pela Universidade Católica de Santos. O tema do concurso foi "Porto e Meio Ambiente" e teve por objetivo "levar à comunidade escolar, conhecimentos sobre questões que envolvem as atividades portuárias", ou seja, criar uma nova cultura portuária a partir da escola.

Para tanto, a comissão organizadora do concurso realizou uma campanha de sensibilização e mobilização com os alunos da educação básica das redes pública e privada. Essa campanha envolveu dois momentos distintos, sendo o primeiro, um passeio de escuna pelo Canal do Estuário (visualizando os berços de atracação das margens direita e esquerda), cuja intenção, da comissão foi levar os alunos para conhecer o complexo portuário.

Durante a excursão, os alunos puderam ver os terminais do porto mais de perto, os embarques de açúcar e os portêineres em operação. A excursão foi amparada por palestra de biólogos, ecologistas, professores de Geografia e técnicos portuários.

O passo seguinte envolveu a produção de um projeto histórico/cultural sobre o "Porto de Santos". Os alunos deveriam realizar uma pesquisa e propor uma ação concreta que contemplasse, a um só tempo, a relação porto, meio ambiente e sociedade.

A partir daqui, vamos recuperar o projeto elaborado por alunos do $3^{0}$ do ensino médio ${ }^{1}$ que participaram e venceram o concurso. Trata-se de uma pesquisa sob o mote "O porto de santos: vivências, percepções e sentimentos", este estudo aborda a relação cidade/porto/sociedade.

O projeto foi elaborado por um grupo de 6 alunos do $3^{\circ}$ ano do ensino médio do colégio Liceu São Paulo. Turma B do ano de 2009. 
Esse projeto foi estruturado em dez partes. Inicialmente apresenta-se a introdução, nessa parte os alunos realizaram um breve resgate histórico que traz a baila elementos da dinâmica do porto que puderam colaborar na compreensão dos vários processos que se sucederam geograficamente e contribuíram de forma significativa para as transformações do porto.

Na sequência, apresentam "o tema e o problema", nessa parte do trabalho, os alunos elaboraram questionamentos para definir a abrangência de sua pesquisa. Logo após, expuseram os objetivos e delimitaram metas mais específicas, dentro do trabalho. Dando seguimento, apresentaram a justificativa da investigação e, nessa parte, relataram o porquê da escolha do tema e a relevância do projeto.

$\mathrm{Na}$ continuação, expuseram a metodologia de trabalho, seguida da descrição dos procedimentos realizados na execução da pesquisa, e da ação proposta. No prolongamento do trabalho, apresentaram o cronograma de atividades, os resultados e as propostas e, por fim, as considerações finais.

\section{O Projeto}

Tema "O porto de santos: vivências, percepções e sentimentos"

\section{INTRODUÇÃO}

A cidade de Santos, sede da região metropolitana da Baixada Santista, tem uma estreita relação com a região metropolitana da cidade de São Paulo, pois é responsável pelo escoamento da produção industrial desta região através de seu porto, o maior e mais movimentado da América Latina.

O Porto de Santos foi inaugurado em 1892, quando a então Companhia Docas de Santos - CDS, entregou à navegação mundial os primeiros 260 metros de cais numa área denominada Valongo.

Após a inauguração do porto, a cidade de Santos, passou por uma transformação significativa, as mudanças não ocorrem apenas no espaço da cidade, mas no cotidiano da população. De acordo com Porto (2012) (apud VIEIRA e BRECIANI, 2014), "os velhos trapiches ${ }^{2}$ e as pontes encravadas em terrenos de água suja de lodo e fétida, foram substituídos por aterros e muralhas de pedra". O projeto de mudança do porto da baía de Santos para

2 Armazens de depósito de mercadorias para importar ou exportar. 
o seu interior, em águas protegidas, inclusive do ataque de piratas foi de Braz Cubas ${ }^{3}$

O porto de Santos, apesar de ter crescido manteve-se com o mínimo de mecanização, por mais de três séculos, predominava no porto o trabalho braçal. Também não eram salubres as condições sanitárias do porto, fato que resultava no aparecimento de doenças de caráter epidêmico. Sobre essa realidade, Mendes, (1992, p. 2), relata,

Tristes tempos aqueles! De velhos pardieiros erigidos em trapiches alfandegados, tortuosas e alquebradas pontes de construção pré-histórica serpenteavam pelo lodaçal até penetrarem algumas braças nas águas turvas da baía. Sob o tremendo bochorno dos dias estivais, a pele suarenta e escaldante, enxameavam por eles turmas de homens brancos, que a sedução de um El Dorado para tantos enganoso atraíra de além-mar, de envolta com os negros filhos da raça escravizada da África, arquejando todos ao peso de carga de que iam aliviando o bojo dos navios e atestando os trapiches. Os barcos, cuja atracação se apresentava problemática por muito tempo ainda, descarregavam mesmo ao largo, sobre pontões - sorte de velhos cascos aposentados, onde as mercadorias, a troco de grossa armazenagem, jaziam até o dia em que o fisco, cobrando-se as respectivas taxas, permitia seu livre ingresso no território nacional.

De acordo com o jornal Novo Milênio (2006) 4, em razão da precariedade da infraestrutura do porto, os produtos eram empilhados às margens do estuário da Praça da Alfândega no Valongo em pátios improvisados. Esses produtos ficavam expostos às intempéries e consequentemente se degradavam rapidamente. Além disso, as autoridades não garantiam a segurança, durante o desembarque das mercadorias, Por conta disso, marginais saqueavam partes das cargas desembarcadas nas praias do estuário.

De acordo com Torres (2008), melhorias vieram no início da operação da "São Paulo Railway", em 1867, ligando, por via ferroviária, a região da Baixada Santista ao Planalto. Essa operação trouxe sensíveis melhoras, não só ao sistema de transportes de cargas, mas, consequentemente ao comércio e ao desenvolvimento da própria cidade de Santos.

Fidalgo e explorador português. Fundador da vila de Santos (hoje cidade), governou por duas vezes a Capitania de São Vicente (1545-1549 e 1555-1556). É considerado, por alguns historiadores, fundador de Mogi das Cruzes.

4 Matéria publicada no Jornal eletrônico Novo Milênio em 12 mar. 2006. Disponível em: <http://www.novomilenio.inf.br/porto/portohos.htm>. Acesso em: 15 dez. 2014 


\subsection{A mOdernizaÇÃo DAS INSTALAÇÕES PORTUÁRIAS: UM PORTO MODERNO E EFICIENTE}

A cultura do café que se estendia, na ocasião, por todo o Planalto Paulista, atingindo até algumas áreas da Baixada Santista, também contribuiu para a ampliação e modernização das instalações portuárias. De acordo com a Companhia Docas do Estado de São Paulo - CODESP (2009), em 12 de julho de 1888, pelo Decreto $n^{0}$ 9.979, após concorrência pública, o grupo liderado por Cândido Gaffrée e Eduardo Guinle foi autorizado a construir e explorar, por 39 anos, depois ampliado para 90 anos, o Porto de Santos, com base no projeto do engenheiro Sabóia e Silva.

Vale dizer que os concessionários constituíram a empresa Gaffrée, Guinle $\&$ Cia com o objetivo de estruturar o porto. Essa empresa mais tarde passou a se chamar Empresa de Melhoramentos do Porto de Santos e, em seguida, Companhia Docas de Santos. Na década de 1970 a então, Companhia Docas de Santos completou 80 anos na ocasião o jornalista e historiador Rubens Rodrigues dos Santos, lembrou uma notícia da época da fundação da CDS que dizia,

É impossível que o comércio do exterior teime em servir-se do porto de Santos: e nós sabemos que muitas companhias já proibiram que suas embarcações demandem tão infeccionada cidade. Até o próprio governo, reconhecendo o perigo, consentiu que a linha do Lloyd desviasse os seus paquetes dos mares santistas. Ora, se o nosso governo assim procede, o que os estrangeiros não farão? Que fazer? Melhorar as condições higiênicas de Santos (CORDEIRO E MEROLA, 2014, p.483).

A Companhia Docas de Santos por meio de obras de saneamento conseguiu transformar as margens lodosas e fétidas do estuário. Isso significou uma nova fase do porto, onde velhos trapiches e pontes fincadas foram substituídos por aterros e muralhas de pedra. Uma nova via ferroviária e novos armazéns foram construídos. Segundo Matos (2004, p. 2 e 3),

O porto, centro dinâmico da cidade, precisava ser constantemente modernizado e ampliado, a área tornara-se polo de atração para os imigrantes recémchegados. Em Santos, o contingente imigrante, em particular de ibéricos, foi incorporado em serviços 
estratégicos ao funcionamento básico da economia agroexportadora nos armazéns de café e docas, onde exerceram atividades de doqueiros, estivadores, ensacadores e carroceiros.

De acordo com o resumo histórico publicado no site oficial do Porto de Santos (2009),

\begin{abstract}
Em 1980, com o término do período legal de concessão da exploração do porto pela Companhia Docas de Santos, o Governo Federal criou a Companhia Docas do Estado de S. Paulo (CODESP), empresa de economia mista, de capital majoritário da União. Atualmente, o Porto de Santos movimenta, por ano, mais de 60 milhões de toneladas de cargas diversas, número inimaginável em 1892, quando operou 125 mil toneladas. Com $12 \mathrm{~km}$ de cais, entre as duas margens do estuário de Santos, o porto entrou em nova fase de exploração, consequência da Lei 8.630/93, com arrendamento de áreas e instalações à iniciativa privada, mediante licitações públicas5.
\end{abstract}

Alguns problemas ameaçam o pleno funcionamento das atividades portuárias. Segundo alguns críticos o crescimento das exportações do Brasil só poderá acontecer com o fortalecimento institucional, tecnológico e da infraestrutura do Porto de Santos. Apesar dos problemas, desde 1892, o porto não parou de crescer, sobreviveu a diferentes ciclos econômicos do país, até chegar ao período atual com amplo uso dos contêineres, marco da revolução no transporte e manuseio de cargas.

O porto de Santos é responsável pela movimentação de pouco mais de $27 \%$ da carga transportada em nosso país, com hegemonia reafirmada ao longo do tempo. Ele dispõe de uma rede de acessibilidade favorável, cuja cadeia produtiva inclui elementos dentro e fora das fronteiras brasileiras. (MONIÉ; VIDAL, 2006). Além disso, estabeleceu novos recordes históricos, ao fechar $2005 \mathrm{com}$ um total de 71,902 milhões de toneladas movimentadas, 6,35\% acima do verificado em 2004 (67,609 milhões). De acordo com o Jornal A Tribuna ( PORTO..., 2015, p. 1),

5 Site oficial do porto de Santos. Disponível em: <http://www.portodesantos.com.br $>$. Acesso em: 15 ago. 2009. 
As estatísticas da Companhia Docas do Estado de São Paulo (CODESP) também dão destaque às exportações, que em 2005 chegaram a 50,399 milhões de toneladas, 10,02\% acima do mesmo período de 2004. Na movimentação mensal, outra marca inédita. Passaram pelo porto santista 5,716 milhões de toneladas de carga durante o último mês de dezembro, 15,04\% de acréscimo em relação ao mesmo mês de 2004. Os números acompanham os recordes estabelecidos pela balança comercial brasileira. Em 2008, o Porto de Santos teve uma participação de $26,5 \%$ na balança comercial do país (exportações importações), correspondente a 50,9 bilhões de dólares FOB ("free on board"). Em 2009 o Porto de Santos, registrou uma nova marca histórica mensal, 8.309.897 toneladas. Foi apurado, durante o mês de agosto de 2009, o movimento de 130.345 contêineres.

Mais do que nunca, os portos podem ser a porta de entrada para o desenvolvimento da economia de um país. Seus rumos e direções estão orientados para alimentar o sistema produção/consumo. Portanto, é inegável a importância deste modal para a economia do país.

No entanto, a consciência da chamada "cidade portuária" é um processo ainda em construção, que poderá resultar em um novo modelo de gestão do porto, compatível com as necessidades dos sujeitos sociais (trabalhadores e usuários), institucionais (autoridade portuária e governos representados) e habitantes da cidade. É preciso defender a disseminação de uma cultura portuária, se desejamos estabelecer a relação cidade/porto/sociedade.

\section{O TEMA E O PROBLEMA}

Durante muito tempo a cidade de Santos esteve de "costas para o porto", mas isso ocorreu em todas as cidades portuárias do mundo. Isso tinha a ver com o ambiente socioambiental do porto.

As movimentações das cargas geravam um passivo ambiental que envolvia desde poluição, gerada pelo escoamento de água de lastro, até acidentes por conta do derramamento de combustíveis no mar.

Os portos eram considerados ambientes insalubres, por conta da sujeira e do mau cheiro. Era comum se jogar no mar restos de cargas avariadas de alimentos, as ruas no entorno dos portos não eram apropriadas para moradia, por serem considerados locais deletérios e não oferecer condições de habitabilidade. 
A alta concentração de ratos também era associada ao porto. No campo social, a atividade portuária era exclusivamente masculina. Isso vinha a explicar a existência de prostíbulos próximos à zona portuária.

$\mathrm{O}$ ambiente social estava associado ao submundo de crimes, drogas e contrabando. Essas condições foram determinantes para que os habitantes das cidades se afastassem dos seus portos, "dando-lhes as costas".

As administrações portuárias brasileiras, todas federais, contribuíram muito para aumentar o conflito da cidade com o porto, o que dificultou a gestão integrada com os interesses da região e da cidade, pois, estavam distantes das cidades portuárias e pouco investia na relação porto/cidade/ sociedade. O que interessava era a geração de lucro e riquezas.

Mas, isto já vem se transformando gradativamente, com a tendência da estadualização e municipalização dos portos, a gestão dos mesmos está sob o comando dos estados e das prefeituras, ou seja, está mais perto da comunidade, usuária e da própria cidade. Como exemplo, podemos citar os portos mais bem sucedidos do mundo tais como: o porto de Xangai, que se tornou o maior porto do mundo, o porto de Singapura, o porto de Roterdã, porto de Hong Kong e o porto de Busan, também conhecido como Pusan na Coreia do Sul. Outros portos que também servem de exemplo são os de Bremen, Hamburgo, Roterdã, Amsterdã, Antuérpia ou Singapura, é impossível visitar essas cidades sem se notar os seus portos.

Embora venha ocorrendo o retorno da chamada "visão integrada urbana", o que significa, "um novo olhar para o porto", basta investigar, junto à população, a ideia que a mesma tem do porto, e concluiremos que se trata de um espaço, ainda muito estranho à cidade e distante da vida urbana. Resta saber se em curto, médio ou longo prazo, esse estranhamento pode ser equacionado e quais alternativas serão capazes de reestabelecer e fortalecer a relação cidade/porto/sociedade.

\section{Objetivo geral}

1. Este projeto tem por objetivo fundamental levar à comunidade escolar conhecimento sobre as questões que envolvem as atividades portuárias, em nossa cidade, por meio de uma campanha de sensibilização e mobilização dos alunos do nível fundamental e do ensino médio. Nossa finalidade é contribuir com a formação de uma nova cultura portuária a partir da escola. 
3.1 Objetivos específicos

- Assinalar a importância da relação cidade/porto/sociedade no sentido de promover a um só tempo uma nova consciência ambiental.

- Promover por meio de ações práticas a interação cidade/porto/ sociedade com um foco socioambiental principalmente nas escolas.

- Levar à comunidade escolar conhecimento sobre as questões que envolvem as atividades portuárias, por meio da escola.

\section{Justificativa}

Se o porto atua como um ímã permanente na atração de negócios e, nesse ponto, com uma capacidade quase que inesgotável, sua importância é crucial para o desenvolvimento da cidade. Isso porque, inerente ao conceito de porto, encontra-se o conceito de cluster de negócios, gerador de riquezas. Essa realidade significa a capacidade competitiva da região, da cidade, das empresas e, principalmente, dos próprios cidadãos.

No entanto, projetos e ações que assegurem a um só tempo a interação cidade/porto/sociedade com um foco socioambiental são especialmente escassos, principalmente nas escolas. Dessa forma, um projeto que tem por objetivo levar a comunidade escolar conhecimento sobre as questões que envolvem as atividades portuárias, por meio da escola, com o intuito de ampliar a relação supracitada, parece, ao mesmo tempo, oportuno e relevante.

A realização de um projeto que tem como tema central "Porto e Meio Ambiente", convida-nos e nos propicia a oportunidade de realizar balanços, rever teorias, de reconstruir ideias, enfim, de propor práticas intelectuais e socioambientais capazes de promover a interação entre o Porto e a cidade de Santos.

\section{Metodologia de trabalho}

Fizemos levantamento documental e pesquisa em fontes secundárias na internet em sites oficiais, artigos on line, teses e dissertações, e em 
livros especializados. Realizamos reuniões periódicas com professores, orientador e colegas do grupo, para trocar informações. Nesse período, tivemos a oportunidade de interagir com os professores e conhecedores das questões portuárias e assim, expor nossas expectativas e ansiedades no tocante à realização deste trabalho. Interagimos, também, com crianças e jovens não só da nossa escola, mas também de escolas da rede pública.

Desenvolvemos uma ação intitulada "A semana do porto na escola" que incluiu várias atividades tais como: concurso de poesias, teatro, exibição de vídeos, música, oficina de desenhos, exposição de fotografias e concurso de maquetes. Essas atividades foram realizadas com o intuitito de tornar lúdico, a produção do conhecimento bem como afirmar a importância do porto para a nossa cidade. Criamos na escola um espaço de discussões por meio de um ciclo de palestras, contamos com a participação de professores de diversas áreas, biólogos e técnicos do porto.

\section{Procedimentos metodológicos da “AÇÃo” proposta no PROJETO}

- Produção de oficina com as crianças do ensino fundamental em duas escolas, sendo uma da rede particular outra da rede pública de ensino. Esta se traduziu em brincadeiras e representações. As crianças puderam por meio de uma atividade lúdica retratar o "Porto de Santos".

- Exposição de desenhos, contação de histórias, usando os desenhos do porto que as próprias crianças produziram.

- Oficina de redação e poesias com os alunos do ensino fundamental e médio. Chamamos de "varal de poesias". Partindo do pressuposto de que o universo da poesia é muito rico e encantador, propusemos um trabalho lúdico, prazeroso e bastante agradável com as crianças e os adolescentes.

- Leitura das poesias no pátio da escola com premiação. As poesias foram publicadas no jornal da escola. Como forma dar visibilidade ao trabalho das crianças e adolescentes e ao nosso projeto.

- Brincadeiras com jogos interativos tais como: palavras-cruzadas, quebra-cabeça e dinâmica de grupo.

- Por fim, apresentação de uma peça teatral sob o mote "O Porto e a Cidade". 
Cronograma do projeto/ação

\begin{tabular}{|l|l|l|}
\hline Data & Agosto & Setembro \\
\hline 1-15 & $\begin{array}{l}\text { Levantamento documental e pesquisa em } \\
\text { fontes secundárias na Internet e em livros } \\
\text { especializados }\end{array}$ & Semana do porto na escola \\
\hline $15-20$ & $\begin{array}{l}\text { Reuniões periódicas com professores, nos- } \\
\text { so orientador e com os colegas do grupo. }\end{array}$ & Exposição dos desenhos \\
\hline $20-25$ & Semana do porto na escola & Varal de poesias. \\
\hline 30 & $\begin{array}{l}\text { Oficlo de palestras } \\
\text { mental }\end{array}$ & $\begin{array}{l}\text { Jadas, quebraterativos: palavras-cru- } \\
\text { ca de grupo. }\end{array}$ \\
\hline 30 & $\begin{array}{l}\text { Peça teatral "O Porto e a Cida- } \\
\text { de" }\end{array}$ \\
\hline
\end{tabular}

\section{Resultados obtidos}

A participação da comunidade escolar em todas as etapas do projeto e a produção cultural com as crianças e adolescentes nos permite afirmar que alcançamos nossos objetivos. Além disso, criamos na escola um espaço de discussões, envolvendo os alunos do ensino fundamental e médio, os professores, os coordenadores e a direção da escola.

Nosso trabalho ganhou visibilidade na cidade, fomos pra rua, panfletamos na praia, chamamos a atenção com faixas na porta da escola e distribuímos folders nos shoppings da cidade. Nosso esforço e empenho pela disseminação de uma nova cultura portuária nos rendeu o $1^{\circ}$ lugar no concurso promovido pela Universidade Católica de Santos e, consequentemente bolsas de estudos nessa instituição como prêmio.

Todavia, o mais importante foi lançar a "semente" no sentido de contribuir para uma nova relação cidade/porto/sociedade, e nós conseguimos, com o apoio da nossa escola e da nossa orientadora. Os resultados do nosso trabalho parecem indicar que efetivamente estamos na direção certa. Sabemos que ainda existe um longo caminho a ser percorrido, mas seguimos na certeza de que valeu a pena.

\section{DAS AÇÕES ÀS SOluÇÕES: NOSSA POSPOSTA - CRIAR E FORTALE- CER UMA NOVA CONSCIÊNCIA PORTUÁRIA}

Indicamos em curto prazo, campanhas de sensibilização e mobilização dos sujeitos que habitam a cidade no sentido de se criar e fortalecer 
uma consciência portuária por meio de boletins informativos com linguagem clara e inteligível, que veiculados nos principais meios de comunicação alcancem a sociedade.

Em médio prazo, apontamos à urgência do projeto "Porto Itinerante". A ideia é que a autoridade portuária, o poder público, as escolas e as universidades da baixada santista, possam viabilizar visitas periódicas dos alunos ao porto de Santos. Para tanto, será necessário, transporte e profissionais aptos para se comunicarem com o público alvo e, assim transmitir-lhe os conhecimentos necessários ao fortalecimento de uma nova cultura portuária. É preciso aproximar o porto da população, e a escola é sem sombra de dúvida um canal importantíssimo para promover essa articulação.

Em longo prazo esperamos que as nossas indicações possam contribuir para uma mudança de mentalidade principalmente na escola em relação ao nosso porto.

\section{Conclusão do Projeto Elaborado E aplicado PElos alunos}

A partir do estudo que realizamos, concluímos que a imagem do "Porto de Santos" está mudando. Se, no passado o porto era um local insalubre, hoje é totalmente diferente. O porto está com baixíssima capacidade de poluição, devido ao predominante uso do sistema de cargas conteinerizadas.

Os grandes contingentes de mão de obra masculina não existem mais e, a cada dia, são substituídos por recursos humanos especializados, onde a presença feminina é cada vez maior. A consolidação de Santos como um "porto de contêiner" é muito importante para a cidade, pela capacidade de abranger um grande número cargas diferentes, muitos usuários e múltiplas atividades associadas.

Programas foram implantados para reduzir o nível de poluição gerada pela queima de combustíveis por navios e caminhões com oferta de novas fontes de energia para os terminais, maior controle sobre as águas de lastro dos cargueiros e sobre os efluentes líquidos no estuário.

Apesar dos avanços, nosso porto ainda demanda muitas obras de infraestrutura e está longe de ser um porto excelente. De acordo com Gireli, Vendrame (2012) suas fragilidades no acesso terrestre e marítimo lhe renderam o título de quarto pior porto do Brasil, com nota 5,7, segundo o ranking elaborado pela Coppead envolvendo cerca de 300 empresas exportadoras, armadores e agências marítimas. Mas ressaltamos que, de acordo com a 
nossa pesquisa, muito vem sendo feito para aperfeiçoar o funcionamento do nosso porto.

Não obstante, a sua intensa especialização tem afetado sua relação com a cidade, acentuando o distanciamento entre eles, por isso, em nosso trabalho propusemos por meio de ações concretas, aproximar o porto e a escola. Para que se fez necessário, antes de tudo, desenvolver uma pesquisa histórico/documental. Pois, apesar de vivermos em uma cidade portuária pouco sabíamos a respeito do porto.

Não foi fácil desenvolver as ações previstas em nosso projeto. Apesar da disponibilidade e prontidão da coordenação da escola, da nossa orientadora e dos nossos professores, enfrentamos algumas dificuldades durante a realização do trabalho. O maior problema que encaramos foi conciliar as atividades escolares - provas, exercícios domiciliares e preparação para o ENEM com as ações do nosso projeto.

Isso, fez com que alguns dos nossos colegas se sentissem desestimulados a participar do projeto. Por isso, no início dos trabalhos a participação dos colegas foi tímida. Para vencer esse obstáculo foi imprescindível realizar várias reuniões para sensibilizá-los.

Outra dificuldade foi documentar as atividades do projeto. Não pudemos fotografar as crianças, durantes as oficinas, devido aos direitos autorais. Alguns pais não permitiram. Mas, apesar dos impedimentos encontrados, foi válida a experiência. Esperamos que nosso trabalho tenha continuidade, não somente em nossa escola, mas em todas as outras escolas da Baixada Santista, e que as nossas dificuldades em conciliar atividades extracurriculares com as atividades diárias da escola seja um exemplo para se pensar o tipo de escola que queremos - conteudista ou formadora de cidadãos?

\section{ConsideraÇÕes FINAIS}

Como conclusão da atividade extraclasse aqui relatada, podemos retirar algumas considerações de importante respaldo analítico. Do ponto de vista dos alunos da educação básica, é fundamental que tenham a experiência da iniciação a pesquisa, ao exercício do livre pensar, com isso quero dizer que uma das principais características do ambiente escolar não é tão somente a difusão de conteúdos, mas principalmente a formação de jovens para a vida.

A oportunidade de coordenar esse trabalho nos conduziu ao exercício da reflexão sobre a prática docente. A mobilização dos alunos por 
meio de oficinas de poesias, desenhos, construção de maquetes, produção de vídeos e fotografias, sugerem o impacto positivo dessas atividades na vida dos alunos da educação básica.

O projeto Cidade/Porto permitiu, à comunidade escolar o encontro direto com outra realidade que, apesar de tão próxima, muitas vezes é estigmatizada e marginalizada. Além disso, possibilitou o encontro entre os diferentes níveis de educação, ou seja, a escola e a universidade, além de uma melhor compreensão e mudança de visão sobre a relação cidade/ porto/ sociedade por parte da comunidade escolar.

Convém tornar compreensível que, a inclusão de atividades no currículo escolar, que extrapolem os muros da escola, pode se constituir no ponto de partida da promoção de uma aprendizagem significativa, haja vista que "o aprender pode se tornar um prazer", pois o conhecimento, ganha novo sentido para o aluno.

Alegria, criatividade, energia e vontade de mudança, são características marcantes dos jovens na atualidade, mas às vezes essas qualidades são desprezadas por muitos de nós, professores.

As políticas educacionais devem privilegiar a abertura de espaços que facilitem a livre expressão de ideias, "o ouvir e ser ouvido", a construção coletiva dos saberes.

Há dinâmicas mais complexas a serem consideradas, para tanto, a escola deve ser o lócus do encantamento do "mundo", lugar onde os alunos possam conversar abertamente sobre os mais diversos temas presentes no seu cotidiano e debater todo tipo de assunto com a comunidade escolar.

Da construção de novas formas, esse pode ser um dos instrumentos de que precisamos para nos mobilizar na produção de projetos que atendam aos mais diversos anseios, trazendo benefícios não só para os nossos alunos, mas para toda a sociedade.

O momento atual sinaliza, portanto, uma transformação, pois os jovens anseiam por um ambiente descontraído e democrático na escola, ou seja, um lugar onde possam exercer a sua cidadania, conquistar o seu espaço e ser ouvidos. Não há mais clima para a repetição automática, para a falta de contextualização.

Isso significa dizer que ao contrário do que muitos afirmam, atividades extraclasses, por meio de projetos que envolvem ações práticas em consonância com os interesses dos alunos, podem fortalecer a autoestima desses adolescentes e estimulá-los a ter responsabilidades, criatividade, e autonomia para desenvolver a criticidade. 
Portanto, faz-se necessário investir tempo e disposição na elaboração de atividades capazes de auxiliar na construção de uma postura critica, diante do mundo. Essa postura traz como consequência a construção da ideia de cidadania vinculada ao "saber se posicionar no mundo". Essa é apenas uma condição inicial, um caminho, uma possibilidade, e não uma formula pronta. 


\section{REFERÊNCIAS}

ANDRADE, K. R. N. de. Porto de Santos: o surgimento da cultura de resistência à globalização. Revista do Departamento de Comunicações e Artes da ECA, São Paulo, v.1, n. 5, p. 77-84, jan.-abr. 2009.

PORTO de Santos bate novo recorde de movimentação mensal. Jornal A Tribuna, Santos, 27 out. 2015. Caderno de Economia, p. ı. Disponível em: <http://www.atribuna.com.br/noticias/ noticias-detalhe/porto $\% 26 \mathrm{mar} /$ porto-de-santos-bate-novo-recorde-de-movimentacao-mensal/?cHash=7agb9f6841dd4b4a84off55cd102d677>. Acesso em: 15 maio 2016.

CORDEIRO, A., MEROLA, A.; MENDES, V. Territorialidades da interface porto/cidade contexto urbano de santos: um estudo de caso sobre o bairro do Paquetá. In: CONGRESSO IBEROAMERICANO DE ESTUDIOS Y AMBIENTALES, 6. VI, 2014, São Paulo. [Anais...?] São Paulo: [s.n.], 2014.

Disponível em: <http://docplayer.com.br/9508429-Territorialidades-da-interface-porto-cidade-contexto-urbano-de-santos-um -estudo-de-caso-sobre-o-bairro-do-paqueta.html>. Acesso em: 15 maio 16

GIRELI, T. Z. V.; FERNANDES, Rafael. Aprofundamento do porto de Santos uma análise crítica. Revista Brasileira de Recursos Hídricos, São Paulo, v, 17, n.3, p. 49-59, Jul/Set 2012. Disponível em: $<$ http://docplayer.com.br/6895910-Aprofundamento-do-porto-de-santos-uma-analise-critica.html>. Acesso em: 14 maio 2016

MATOS, M ${ }^{a}$ I. Santos de. O porto do café: cidade, cotidiano e trabalho. Revista Estudos Ibero-Americanos, Porto Alegre, v. 33, n. 2, p. 9-26, dez, 2004. 
MENDES, C. P. No tempo dos trapiches. O Estado de São Paulo, São Paulo, 28 jan 1991. Caderno Marinha Mercante, p. 2. MONIÉ, F. VIDAL, S. M. do S. C. Cidades, portos e cidades portuárias na era da integração produtiva. Revista RAP, Rio de Janeiro, v. 40, n. 6, p. 975- 995, 2006.

TORRES, Luiz Fernando Ribeiro. Estudo analítico e operacional da supervia eletrônica de dados: um modelo de gestão eletrônica para os portos brasileiros. 2008. 157p. Dissertação (Mestrado em Engenharia)- Escola Politécnica da Universidade de São Paulo, Universidade de São Paulo, São Paulo, 2008.

VIEIRA, Sirlei Tereza Pitteri, BRESCIANI, Luís Paulo.

Competências territoriais em perspectivas teóricas e empíricas: o caso do Complexo Portuário de Santos, SP. Revista Brasileira de Gestão e Desenvolvimento Regional. v. 11, n. 1, p. 243-272, jan-abr/2015, Taubaté, SP, Brasil. Disponível em www. rbgdr.net/revista/index.php/rbgdr/article/download/1617/436.

Data de acesso: 15/05/16 


\section{A SALA TEMÁTICA \\ COMO UM RECURSO \\ DIDÁTICO \\ NAS AULAS DE \\ GEOGRAFIA}

Lincoln Santos dos Reis

Namara Santos Lopes

Tereza G. N. Torezani Fontes

\section{INTRODUÇÃO}

A Geografia é uma área do conhecimento comprometida em tornar o mundo compreensível para os alunos, explicável e passível de transformações. Contudo, muitos professores que atuam na área passam por dificuldades e se frustram diariamente no desempenho de suas funções, especialmente no momento de estabelecer relação entre os conteúdos e o cotidiano dos alunos, a realidade concretamente vivenciada e experenciada por eles.

Dessa forma, de acordo com o Ministério da Educação e Cultura (MEC), a escola pública, em todos os níveis e modalidades da educação básica (educação infantil, ensino fundamental e médio), tem como função social formar o cidadão, isto é, construir conhecimentos, atitudes e valores que tornem o aluno solidário, crítico, ético e participativo nas decisões da sociedade.

A dificuldade dos professores de Geografia em estabelecer tais relações é uma das questões essenciais assinaladas por autores que discutem e debatem o ensino de Geografia (VESENTINI, 2004; CALLAI, 2002; OLIVEIRA, 1994; KAERCHER, 2002).

Diante dessa realidade, o impasse se revela: como favorecer o processo ensino-aprendizagem da disciplina Geografia e dirimir as dificuldades e frustrações experimentadas por professores dessa área? A utilização de recursos didáticos diferenciados e atraentes pode ser uma aliada na resolução de tal impasse. É nesse contexto que se insere a necessidade de implantação de uma sala temática de Geografia.

Assim, ao mesmo tempo em que a construção de conceitos geográficos vai acontecendo, criam-se condições dinâmicas de esclarecimento 
dos mesmos com a utilização da sala temática. As possibilidades de explorações temáticas e conceituais da Geografia a partir dos recursos em uma sala ambiente são muitas e a construção do conhecimento, em Geografia, pode ser facilitada pelo uso amplo e adequado dos recursos: globo terrestre, mapas, maquetes, jogos pedagógicos, revistas e outros materiais de consulta, aparelhos para medição de elementos climáticos, cartazes, mostruários de rochas e minerais, aparelhos para orientação, recursos audiovisuais (vídeo, slides, transparências), entre outros.

$\mathrm{O}$ aspecto e as estruturas físicas do ambiente exercem forte impacto sobre as ações dos alunos e, consequentemente, sobre sua aprendizagem. Nesse sentido, o presente artigo - resultado de uma monografia produzida no Curso de Especialização em Ensino de Geografia da UESC - teve como objetivo elaborar uma análise da sala temática como objeto de estudo do ensino de Geografia, estabelecendo um comparativo entre as aulas ministradas com e sem o uso desse tipo de sala.

Para alcançar os objetivos dessa pesquisa foram feitas revisões em bibliografias referentes ao assunto; simultaneamente foi aplicado um roteiro de observação sistemática em campo para a coleta de dados; finalmente, foi feito um registro narrativo de tudo o que foi constatado no período de observação.

\section{A IMPORTÂNCIA DA SALA TEMÁTICA PARA O PROCESSO ENSINO -APRENDIZAGEM}

Conforme observa Castrogiovanni (2000), a escola não tem se mostrado atraente frente ao mundo contemporâneo, pois não dá conta de explicar e contextualizar as novas leituras de vida. A escola parece ser homogênea, transparente e sem brilho. Já a vida fora da escola é cheia de mistérios, emoções, desejos e fantasias. Nesse sentido, é importante e urgente que se teorize a vida, para que o aluno possa compreendê-la e representá-la melhor. Como observou Kaercher (2002, p. 24): "Em minhas constatações a escola continua sendo um espaço de desconforto, desânimo $[\ldots] "$.

Vivemos, hoje, os desafios de uma revolução tecnológica que, paulatinamente, insere-se nos espaços escolares. No entanto, tais espaços, em muitas situações, não se apresentam de forma estruturada e organizada para tal feição. Percebe-se, cada vez mais, a necessidade de uma adequação efetiva dos ambientes escolares para que os mesmos possam se tornar interessantes instrumentos pedagógicos (CALLAI, 2002). 
Esta situação também é constatada por outra autora ao afirmar que:

O processo de ensino/aprendizagem realiza-se apoiado nas relações que se estabelecem entre professores, alunos e condições oferecidas ao processo pedagógico, constituindo um tripé que, se não for fortalecido em todas as suas bases, não oferecerá as condições necessárias à melhoria do processo (SPÓSITO, 2002, p. 308).

A maioria dos alunos não demonstra interesse pelos saberes das disciplinas, e na Geografia não é diferente. Conforme assinala Castrogiovanni (2000), muitos ainda acreditam que a Geografia é uma disciplina desinteressante, elemento de uma cultura que necessita da memória para reter nome de rios, regiões, países, altitudes, etc. Straforini (2004) reforça a afirmativa de que, na Geografia Escolar os conteúdos são tratados de forma superficial, apresentados de forma fragmentada e sem qualquer relação com a realidade e as demais disciplinas.

Para entender essa desmotivação, parte-se do pressuposto de que a causa desse problema pode estar no contexto das próprias aulas de Geografia onde, em muitos casos, o professor somente transmite conhecimentos. Da mesma maneira, o problema pode estar nas estratégias didáticas utilizadas pelos professores ou, mesmo, na falta destas, pois, nem todas as escolas possuem recursos didáticos, e nem todos os professores estão aptos ou dispostos a utilizar tais recursos, determinando, assim, desafios para o ensino de Geografia. Da mesma forma:

Todo professor que tentou inovar radicalmente, que mudou a sua prática educativa procurando realizar bons estudos do meio, selecionar textos críticos para leitura e discussão, abordar novos temas/problemas etc. conhece muito bem as enormes dificuldades que enfrentou (VESENTINI, 2004, p. 245).

Ou seja, professores planejam suas aulas, selecionam recursos didáticos necessários para a tarefa pedagógica, e a escola, por sua vez, não dispõe dos materiais indispensáveis para viabilizar a proposta didática planejada ou, se eles existem, são precários, obsoletos. Como discutem Pontuschka e Oliveira (2002, p. 189): "[...] o modo como o professor percebe a realidade pode se constituir em uma barreira, impedindo-o de ousar e experimentar alternativas pedagógicas".

Em muitos casos, a formação do professor é limitada, a utilização dos recursos é, para ele, um obstáculo, porque também não teve uma alfabetização geográfica e, assim, deparou-se com dificuldades na construção 
de noções e na elaboração de conceitos básicos que poderiam tornar mais concreto o ensino- aprendizagem.

Seja, então, por conta das dificuldades operacionais e materiais encontrados pelos docentes ou do próprio modo como o professor percebe a realidade e se posiciona frente a ela, o fato é que a prática de ensino nas aulas de Geografia merece tomar novos rumos.

Conforme afirma Xavier (2002, p. 65),

a prática do ensino da Geografia deve assegurar espaços de aprendizagem próprios, adequados à nova realidade do mundo e, assim, particularmente, à realidade da comunidade envolvida.

Busca-se uma prática pedagógica para ser alternativa ao ensino convencional, com utilização de metodologias e recursos os mais variados:

Diante desta questão existe por parte dos professores a utilização de diversas linguagens e recursos tecnológicos para se ensinar Geografia, tais como: cinema, fotografia, poesia, música, aulas temáticas, trabalhos de campo e, ainda, a utilização do espaço cibernético para interpretação e análise de ilustrações, charges, mapas, cartas, gráficos e tabelas, dentre outros (CAVALCANTI, 2005, p. 87).

Nesse sentido, é urgente repensarmos o estudo dos conteúdos geográficos, questionando fórmulas prontas, principalmente a dos livros didáticos e dos programas oficiais. O professor é fundamental nesse processo, afinal, um educador- geógrafo deve contribuir para a construção de uma escola cada vez mais voltada para a vida cidadã e de uma Geografia escolar cada vez mais útil e necessária (SILVA, 2004).

\section{O ENSinO de Geografia a PARTIR do uso da SALA TeMÁtica}

A sala temática articula um espaço lúdico com o cotidiano escolar do aluno, ampliando as possibilidades para que ele possa se expressar e se integrar ao ambiente que o cerca. Por meio das atividades lúdicas ele assimila valores, adquire conhecimento em diversas áreas do conhecimento, desenvolve o comportamento e aprimora as habilidades motoras. Por meio do lúdico o raciocínio é estimulado de forma prazerosa e a motivação para aprender é resgatada (SANTOS, 1999). 
Para Menezes e Santos (2002), sala ambiente é uma sala de aula na qual se dispõe de recursos didático-pedagógicos que atendam a um fim educacional específico. Os recursos didáticos utilizados tanto podem ser aqueles materiais já confeccionados como aqueles confeccionados na própria escola.

A existência de um espaço lúdico com recursos de ensino em sala de aula pode oferecer ao aluno possibilidades para que amplie sua leitura de mundo e sua ação crítica com base nas informações que tais recursos venham a oferecer.

Para Piletti (2006, p. 154), quando os usamos de maneira adequada, os recursos de ensino colaboram para:

- Motivar e despertar o interesse do aluno;

- Favorecer o desenvolvimento da capacidade de observação;

- Aproximar o aluno da realidade;

- Visualizar ou concretizar os conteúdos da aprendizagem;

- Oferecer informações e dados;

- Permitir a fixação da aprendizagem;

- Ilustrar noções mais abstratas;

- Desenvolver a experimentação concreta.

Em qualquer especialidade, utilizar-se de recursos didáticos para facilitar a aprendizagem é de grande importância, entretanto, a utilização destes recursos nas aulas de Geografia é mais significativa ainda, na medida em que servem de mediadores entre os conteúdos e o aluno, além de colocá-lo em contato maior com a materialidade.

Nesse sentido, conforme assinala Oliveira (2009, p. 5):

A adoção do uso dos recursos didáticos em uma sala temática de Geografia contribui para uma maior compreensão da sociedade, como o processo de ocupação dos espaços naturais, baseado nas relações do homem com o ambiente, em seus desdobramentos políticos, sociais, culturais e econômi$\cos$ - função fundamental do ensino de Geografia.

Cioccari (2012) assinala que uma sala-ambiente é mais do que um espaço diferenciado, é uma concepção de ensino que se distingue da tradicional, pois neste ambiente o aluno pode vivenciar, experimentar e praticar 
a Geografia, o que contribui para a sua formação temporal e espacial, e o insere de forma mais harmoniosa neste mundo em transformação.

Sendo assim, a implantação de uma sala temática é uma construção coletiva de conhecimento, na qual os recursos pedagógicos disponíveis podem dinamizar os trabalhos e enriquecer as atividades de ensino-aprendizagem da ciência geográfica, tornando esse processo mais prazeroso e eficaz. Além disso, é um espaço propício para estimular a construção e compreensão de conceitos, procedimentos e habilidades da ciência geográfica, ao mesmo tempo em que cria atitudes positivas em relação à mesma.

A observação e análise do espaço são fundamentais para que o aluno entenda os fenômenos geográficos e, na sala temática, essas tarefas se tornam mais relevantes a partir da utilização de alguns recursos (QUADRO 1).

\section{QUADRO 1 - Exemplos de materiais para sala temática de Geografia}

\begin{tabular}{|l|l|}
\hline Item & Descrição \\
\hline o1 & Globo terrestre. \\
\hline o2 & CDs E DVDs de documentários, filmes, músicas. \\
\hline 03 & Atlas, livros, revistas, jornais, cordéis. \\
\hline 04 & Mapas temáticos, cartas topográficas, plantas de municípios ou bairros. \\
\hline 05 & Maquetes variadas, painéis. \\
\hline 06 & Bingos geográficos. \\
\hline 07 & Jogos pedagógicos da área. \\
\hline 08 & Aparelhos para medição de elementos climáticos: termômetros, pluviômetros. \\
\hline o9 & Fotografias aéreas, gravuras, cartões postais, imagens de satélites. \\
\hline 10 & Mostruários de rochas e minerais. \\
\hline 11 & Aparelhos para orientação: bússolas, GPS. \\
\hline 12 & Recursos audiovisuais: aparelho de DVD, projetor de slides. \\
\hline
\end{tabular}

Fonte: Dados da pesquisa.

É interessante, também, disponibilizar matéria-prima para a confecção de outros materiais didáticos, como é o caso de: tinta, lápis de cor, giz de cera, massa de modelar, cartolina e materiais recicláveis como garrafas pets, cola, tesoura, entre outros.

De posse desses recursos materiais, aliado a um mobiliário que os exponha, a sala temática está pronta e propícia que o professor possa trabalhar os conteúdos articulados a um método ou a uma técnica que facilitará a compreensão do aluno, provocando uma situação de aprendizagem.

A FIGURA 1 demonstra a construção de uma sala temática, aonde o espaço vai ganhando forma e identidade geográficas, propiciando um estímulo a mais para a assimilação dos conteúdos da disciplina. 
FIGURA 1 - Sala temática de Geografia
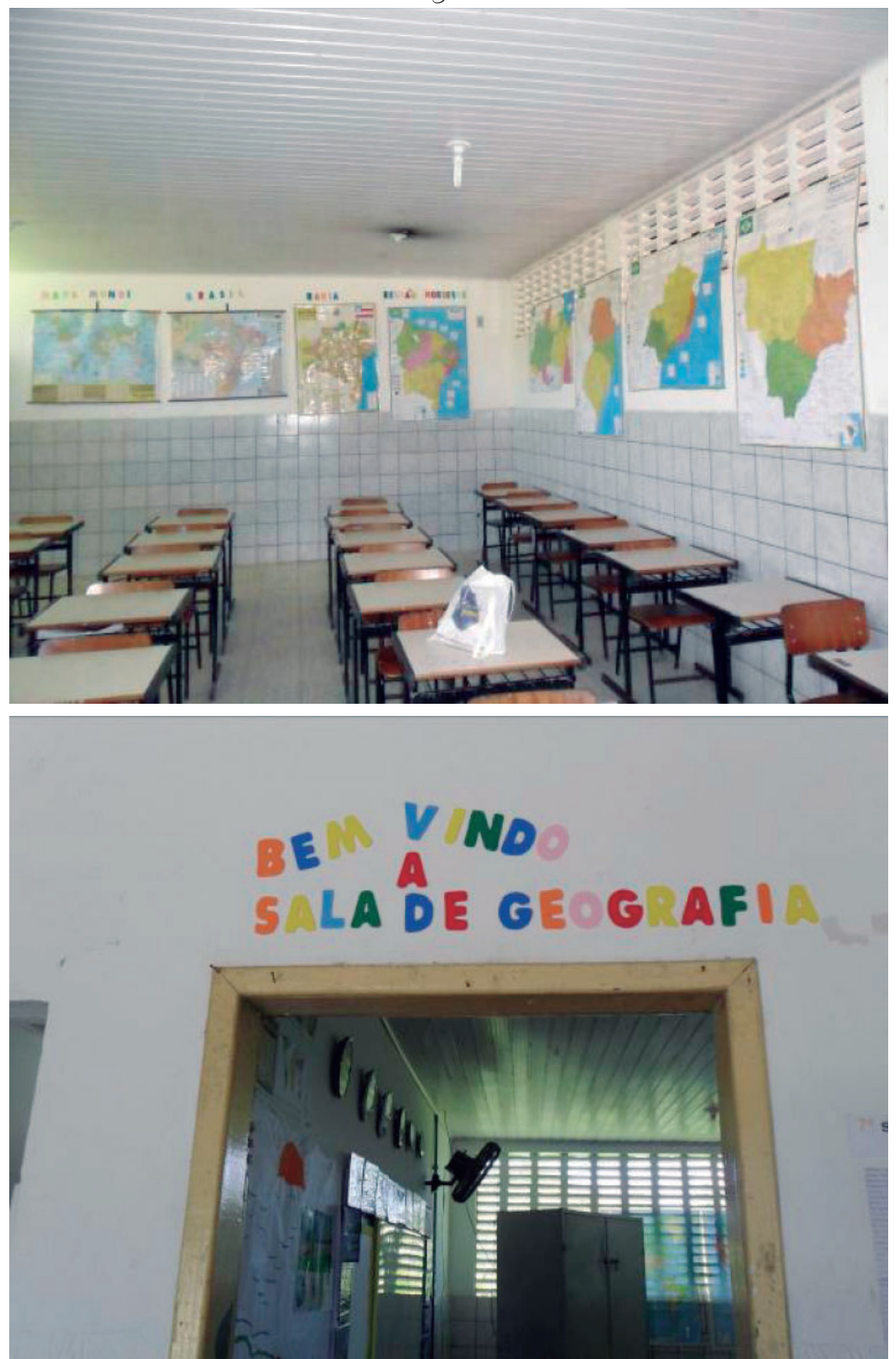

Fonte: Namara Santos Lopes, 2013. 
Enfim, a estratégia é mobilizar a curiosidade e o conhecimento que o aluno está construindo e, com base nisso, conduzir atividades em que vai localizar, mapear, comparar e analisar criticamente os fenômenos discutidos, ou seja, a proposta dessa alternativa pedagógica é facilitar o processo de ensino-aprendizagem, articulando teoria e prática (CIOCCARI, 2012).

\section{Comparativo ENTRE aS aUlas ministradas Na SALA CONVENCIO- NAL E NA SALA TEMÁTICA}

$\mathrm{Na}$ tentativa de obter um comparativo entre as aulas ministradas na sala convencional e na sala temática foi realizada uma observação com 30 alunos do $8^{\circ}$ ano da Escola Nucleada da rede municipal de ensino, de Ilhéus-BA. O roteiro da observação foi dirigido com a finalidade de verificar a interação dos alunos durante cinco aulas ministradas na sala convencional e cinco aulas na sala temática. Os assuntos trabalhados nas aulas foram: orientação, localização e fusos horários. O plano de aula foi levado a efeito, entretanto, com algumas alterações, já que as aulas na sala temática tiveram o auxílio dos equipamentos que lá se encontravam (FIGURA 2).

FIGURA 2 - Comparativo entre as aulas ministradas na sala temática de Geografia e na sala convenciona

Comparativo entre as aulas ministradas na sala temática e na sala convencional

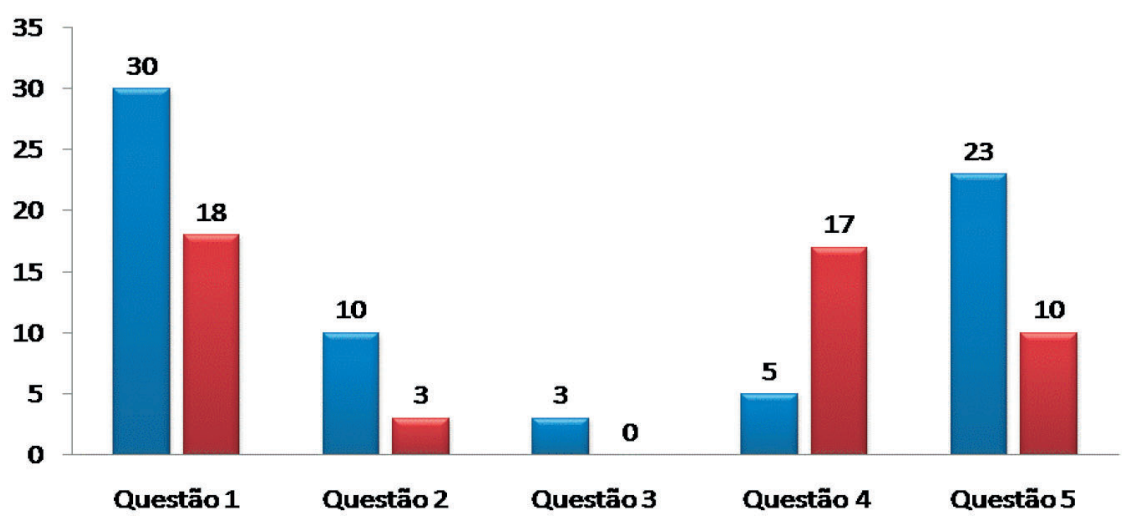

Questão 1- $O$ aluno presta atenção durante a explanação da aula? Questão 2- $O$ aluno Responde aos questionamentos da professora? Questäo 3-O aluno faz questionamentos? Questão 4- $O$ aluno pede orientação da atividade proposta na aula? Questāo 5-O aluno realiza a atividade proposta com êxito?

Fonte: Namara Santos Lopes, 2013.

Legenda: Sala Temática; Sala convencional. 
Assim, durante os trinta minutos de explanação da aula na sala temática, conseguiu-se obter a atenção máxima dos alunos, trinta ao todo, ou seja, todos os alunos estiveram bastante atentos, mostrando-se muito curiosos com aquela formatação de aula, onde vários recursos eram utilizados, enquanto na sala convencional a mesma aula ministrada com os recursos utilizados habitualmente, como o quadro branco e canetas piloto, obteve apenas a atenção integral de dezoito alunos.

A professora fez três questionamentos referentes à temática da aula. Durante a aula ministrada na sala convencional, apenas três alunos se prontificaram a responder, enquanto que na sala temática dez alunos tentaram responder utilizando os recursos ao seu alcance.

A professora deixou espaço para que os alunos fizessem também questionamentos referentes ao que foi explanado na aula. Na sala convencional nenhum aluno se pronunciou, enquanto na sala temática três alunos se arriscaram a formular perguntas.

Foram realizadas três atividades durante as aulas. Na sala convencional dezessete alunos pediram orientações à professora, enquanto na sala temática apenas cinco alunos pediram orientação. Esse fato revela que, na sala temática os alunos tiveram maior autonomia, enquanto na sala convencional as atividades indicaram ser mais complicadas.

Ao realizar a correção das atividades para verificar se os alunos as executaram com êxito, na sala temática dezenove tiveram sucesso; já, na sala convencional só dez tiveram um bom resultado. Isto nos leva a concluir que a aula na sala temática oferece melhores condições de aprendizagem.

\section{Conclusão}

Os resultados deste trabalho demonstraram que, ao levar para a sala de aula materiais e propostas de trabalho centradas na ludicidade, despertou-se a curiosidade dos alunos, até mesmo daqueles que, por vezes, não se interessavam pelo conteúdo. Quando observaram a utilização de um recurso didático queriam saber do que tratavam os assuntos e procuravam participar. Assim, presume-se que houve maior integração entre os alunos e os conteúdos, de maneira prazerosa e altamente proveitosa.

Os alunos foram convidados, também, a confeccionar os próprios recursos didáticos, e ao desempenharem esta atividade, demonstraram envolvimento e satisfação, participando ativamente na aula, criando e manipulando materiais. Habitualmente é o professor quem manipula os materiais e, somente em seguida, os apresenta aos alunos. 
No que se refere aos recursos cartográficos, como estes estavam sempre ao alcance dos alunos, permitiram um aguçamento de sua curiosidade. À medida que eram citados fatos ocorridos em localidades desconhecidas, os alunos imediatamente procuravam os lugares nos mapas ou no globo, ou seja, estas ferramentas trouxeram, para o campo de visão daqueles usuários, uma parte da realidade distante, e, assim, incentivaram o seu processo de construção do conhecimento autônomo, ao mesmo tempo em que permitiram maior interação dos mesmos com a Geografia enquanto ciência espacial.

Os materiais da sala temática de Geografia se mostraram úteis, também, para outras disciplinas. Isso foi constatado durante o conselho de classe, no qual o professor de História relatou ter tido bom proveito dos materiais.

Com a realização deste projeto houve evidências de que a experiência da utilização de sala temática para as aulas de Geografia serviu como um ambiente que facilitou o processo ensino-aprendizagem tanto para o aluno como para o professor, na medida em que permitiu reorganização, reestruturação e ressignificação do trabalho pedagógico.

Sabe-se que a Geografia Escolar influencia sobremaneira a formação do aluno, do homem-cidadão, por conseguinte, a importância dessa metodologia de trabalho é indiscutível. É necessário que os profissionais da área se deem conta da sua responsabilidade: a de desempenhar um trabalho pedagógico atraente, desafiante e inovador, que contribua para um conhecimento significativo. A experiência relatada nesse artigo revelou apenas algumas das possibilidades abertas para se alcançar essa meta, através do uso da sala temática nas aulas de Geografia, na educação básica. 


\section{REFERÊNCIAS}

BRASIL. Secretaria de Educação Fundamental. Parâmetros Curriculares Nacionais: Geografia. Secretaria de Educação Fundamental. Brasília, DF: MEC: SEF, 1998.

CALLAI, H. C. Projetos interdisciplinares e a formação do professor em serviço. In: PONTUSCHKA, Nídia; OLIVEIRA, Ariovaldo U. Geografia em perspectiva. São Paulo: Contexto, 2002. p.

CASTROGIOVANNI, A. C. (org.). Ensino de Geografia: práticas e textualizações no cotidiano. Porto Alegre: Mediação, 2000.

CAVALCANTI, L. de S. Geografia e práticas de ensino. Goiânia: Alternativa, 2005.

CIOCCARI, C. C. Sala ambiente de Geografia em escola pública. 2012. Disponível em: <http://unicruz.edu.br/mercosul/pagina/anais/2012/Educacaoedesenvolvimentohumano/ artigo/salaambientedegeografiaemescolapublica.pdf $>$. Acesso em: 20 mar. 2012.

FIORENTINI, D.; LORENZATO, S. Investigação em educação matemática: percursos teóricos e metodológicos. Campinas: Autores Associados, 2006.

KAERCHER, N. A. O gato comeu a Geografia Crítica? Alguns obstáculos a superar no ensino-aprendizagem de Geografia. In: PONTUSCHKA, N. N.; OLIVEIRA, A. O. (Orgs.). Geografia em perspectiva. São Paulo: Contexto, 2002. p. 221-231.

LIMA, M. G. A pesquisa acadêmica e a sua contribuição para a formação do professor. In: PONTUSCHKA, N. M.; OLIVEIRA, A. O. (org.). Geografia em perspectiva. São Paulo: Contexto. 2002. 
LIMA, M. W. S. Arquitetura e educação. São Paulo: Studio Nobel, 1995.

MENEZES, E. T.; SANTOS, T. H. dos. Sala ambiente.

Dicionário Interativo da Educação Brasileira. Educa Brasil.

[S.l., [21-?]]. Disponível em: <http://www.educabrasil.com.br/ eb/dic/dicionário.asp? Id=62>. Acesso em: 29 abr. 2012.

OLIVEIRA, M. L. T. de. Ensino de Geografia na contemporaneidade: o uso de recursos didáticos na sua abordagem. [S.l.], 2009. Disponível em: <http://www.agb.org.br/ XENPEG/artigos/GT/GT5/tc5\%20(51).pdf $>$. Acesso em: 29 abr. 2012.

OLIVEIRA, A. U. Situação e tendências da Geografia. In: (org.). Para onde vai o ensino de Geografia? 4. ed. São Paulo: Contexto, 1994.

PONTUSCHKA, N. N.; OLIVEIRA, A. U. (org.). Geografia em perspectiva: ensino e pesquisa. São Paulo: Contexto, 2002. SANTOS, M. P. dos. Brinquedoteca: o lúdico em diferentes contextos. 4. ed. São Paulo: Vozes, 1999.

SILVA, O. A. da. Geografia: metodologias e técnicas de ensino. Feira de Santana: Editora da Universidade Estadual de Feira de Santana, 2004.

STRAFORINI, R. Ensinar Geografia: o desafio da totalidade -mundo nas séries iniciais. São Paulo: Annablume, 2004.

SPÓSITO, M. E. As diferentes propostas curriculares e o livro didático. In: PONTUSCHKA, N. N.; OLIVEIRA, A. U. (org.) Geografia em perspectiva: ensino e pesquisa. São Paulo:

Contexto, 2002.

VESENTINI, J. W. Geografia Crítica e ensino. In: OLIVEIRA, A. U. (org.). Para onde vai o ensino de Geografia? 4. ed. São Paulo: Contexto, 1994. 
VESENTINI, J. W. O ensino de Geografia no século XXI. Campinas: Papirus, 2004. (Coleção Papirus Educação).

XAVIER, H. A incorporação da dimensão do turismo do ensino da Geografia. In: PONTUSCHKA, N. N.; OLIVEIRA, A.

U. (org.). Geografia em perspectiva: ensino e pesquisa. São Paulo: Contexto, 2002. 


\section{A LITERATURA COMO \\ RECURSO NO ENSINO \\ DE GEOGRAFIA: \\ $7^{\circ}$ ano do ensino \\ fundamental}

\section{Luziana Carvalho dos Santos \\ Glória Maria de Oliveira Silva \\ Tereza G. N. Torezani Fontes}

\section{INTRODUÇÃO}

O estudo em questão é uma pesquisa bibliográfica referente ao ensino de Geografia e à relevância de textos literários, bem como a preparação de uma proposta didática para as aulas de Geografia. O ensino, precisamente o de Geografia, muitas vezes está sendo transmitido a partir de aulas tradicionais, nas quais o aluno é obrigado a memorizar o conteúdo, esquecendo que "O ensino de Geografia, seja ele em qual nível for, deve buscar a totalidade-mundo" (STRAFORINI, 2004, p. 84).

O processo de ensino e aprendizagem é imbuído de uma série de significados. $\mathrm{O}$ ato de ensinar e, sobretudo, de aprender, é carregado de buscas e muita reflexão. Educar não é um ato de transmissão de saberes, pois, nesse processo, tanto professor quanto alunos se envolvem num movimento contínuo de troca. Procurar buscar e utilizar metodologias que assegurem não só o conteúdo, mas a garantia da aprendizagem por parte do aluno, tornando o ensino de Geografia mais prazeroso e, sobretudo, atraente.

O estudo tem como objetivo principal analisar a linguagem geográfica presente nos textos literários, aplicados no ensino de Geografia no $7^{\circ}$ ano do ensino fundamental. Como objetivos específicos, discutir a importância do texto literário para o ensino de Geografia, propor a utilização de textos literários para o ensino de Geografia do $7^{\circ}$ ano do ensino fundamental e, ainda, elaborar uma proposta didática de como usar os textos literários.

Utilizar metodologias de ensino que consigam inserir os alunos no seu contexto social, através de diálogos abertos, irá tornar o ensino da Geografia algo produtivo e interligado às inovações do mundo moderno, no qual nossos alunos estão inseridos. 
Entende-se que a busca por novas formas de aprendizagem deve fazer parte do cotidiano dos professores. Quando se chega à sala de aula, muitas vezes, os alunos já estão cansados e sem ânimo para trocarem as experiências vividas com as que a escola tem a oferecer. Segundo Straforini (2004, p. 81), "O aluno deve ser inserido no que se está estudando, proporcionando a compreensão de que ele é um participante ativo na produção do espaço geográfico".

Inovar as aulas de Geografia é torná-las interessantes e críticas, pois instiga a curiosidade dos alunos e interliga assuntos que, nos livros didáticos, parecem não ter conexão. De forma mais específica se pode dizer que, além de uma renovação no modo de ensinar, a construção do conhecimento, através de metodologias variadas, é uma atividade que aproxima o aluno da realidade que o cerca e o faz entender melhor sua relação com o mundo.

\section{O ensino de Geografia na sala de aula}

O ensino de Geografia no Brasil está intimamente ligado à fundação da Universidade de São Paulo (USP), em 1934. Inicialmente era concedido ao profissional habilitação para também ensinar História. Em 1957, com a separação entre esses dois cursos, a Geografia passou a ser trabalhada e pensada como uma disciplina meramente decorativa, enfadonha, descritiva, em que a habilidade da memorização era extremamente valorizada. Como fonte de conhecimento, o professor se baseava no livro didático como forma de transmissão do conteúdo, muitas vezes desconectados e não relacionados com a realidade do aluno e sua relação com o meio:

O que ocorre na realidade é que os professores (todos), obviamente os de Geografia também, estão envolvidos num processo dialético de dominação, qual seja, o professor foi educado a ensinar sem pôr em questão o conteúdo dos livros didáticos, sem que o produto final de seus ensinamentos fossem ferramentas com as quais eles e seus alunos vão transformar o ensino que praticam e, certamente, a sociedade em que vivem (OLIVEIRA, 1990, p. 28).

Desta forma, ensinar Geografia é transmitir conceitos do mundo em que todos estão inseridos, assim conforme ressalta Lacoste (1989, p. 251):

Para fazer compreender quais são os problemas fundamentais que coloca o ensino da Geografia e a importância das 
lutas, parece-me indispensável lembrar isso: a Geografia já existia bem antes que aparecesse, no século XIX, sua forma escolar e universitária. Desde há séculos, desde que existem os mapas, ela é um saber indispensável aos príncipes, aos chefes de guerra, aos grandes comissários do Estado, mas também aos navegadores e aos homens de negócios, ao menos para aqueles cujo espírito de empreendimento se exerce além do quadro espacial que lhes é familiar.

Geralmente o que acontece em sala de aula é uma preocupação por parte dos professores, especificamente os de Geografia, em abordar tudo o que está nos livros didáticos, esquecendo-se de selecionar o que realmente tem importância para a vida do aluno enquanto cidadão. Segundo Pontuschka (2009, p. 98),

A falta de domínio de conceitos básicos por parte dos alunos, sobretudo em Geografia, envolvendo conhecimentos tanto da natureza quanto da sociedade, levam os professores, muitas vezes com certo desespero, a tentar abarcar uma gama enorme de conteúdos na tentativa de suprir essa deficiência. Tal prática com frequência se revela frustrante justamente porque não só é impossível dar conta de todo o conteúdo, mas, em muitos casos, ele é abordado de forma desligada da realidade.

A Geografia é uma ciência rica em seu conteúdo, sendo o espaço geográfico seu campo de estudo. Assim, cabe aos professores aprimorar suas formas de ensinar, a fim de satisfazer os anseios dos alunos, pois, em muitos casos, somente levam textos desconectados e complexos, os quais têm pouco a ver com a realidade cotidiana destes, não exercendo suas capacidades de reflexão. Em conformidade com Castrogiovanni (1999, p. 129),

A seleção do material didático utilizado deve ser alvo de uma constante discussão; inicialmente, deve ser feita uma reflexão profunda, a partir de questões metodológicas da Geografia.

No processo de ensino-aprendizagem é vital a interação do professor e aluno. Juntos podem ampliar o conhecimento e fazer com que o ensino de Geografia se insira em um novo patamar na educação. Para tanto: 
O professor deve deixar de dar os conceitos prontos para os alunos, e sim, juntos, professor e alunos participarem de um processo de construção de conceitos e de saber. Nesse processo, o professor deixa de ser um mero transmissor de conhecimentos e o aluno mero receptáculo do saber (OLIVEIRA, 1990, p. 140).

Castrogiovanni (1999, p. 66) afirma que

É fundamental de parte do professor uma atitude de questionamento, de provocação, de abertura à inquietude, curiosidade, deslumbramento do aluno, dos muitos mundos que os alunos representam.

O professor deve estar atualizado com métodos novos de ensino e estimular o aprender, mas como fazer? Desta forma:

O objetivo dos professores compromissados com o ensino é fazer escolhas ou opções que elevem os alunos a patamares superiores do ponto de vista da abstração e da consciência sobre a importância do conhecimento do espaço geográfico para sua vida como ser humano e como cidadão participante deste mundo complexo (PONTUSCHKA et al., 2009, p. 76-77).

No $7^{\circ}$ ano do ensino fundamental os objetivos não devem ser diferentes dos demais, porém, é importante lembrar das peculiaridades didáticas próprias desse ano escolar:

Alguns pesquisadores como Callai (1998), Gebran (1990), Le Sann (1997) e Kaercher (1998) vêem no ensino de Geografia para crianças uma das possibilidades da formação do cidadão através de um posicionamento crítico em relação às desigualdades sociais identificadas na realidade concreta das crianças (STRAFORINI, 2004, p. 79).

Os alunos são os principais protagonistas do conhecimento, assim, o professor deverá planejar suas aulas numa sequência lógica que possibilite despertar as habilidades dos alunos para desvendarem as interações que ocorrem no espaço de sua vivência. Nesse sentido, Claval (1999, citado por LIMA, Angélica; LIMA, José, 2007, p. 6) aponta a literatura como um caminho seguro a ser percorrido pela Geografia: 
O romance torna-se algumas vezes um documento: a intuição sutil dos romancistas nos ajuda a perceber a região pelos olhos de seus personagens e através de suas emoções.

A Geografia possibilita conhecer outros espaços e modos de vida sem, necessariamente, estarmos no lugar estudado, pesquisado, imaginado. As obras literárias são uma forma de experienciar os diversos lugares, os diversos "mundos".

\section{A literatura como recurso didático nas aUlas de Geografia}

Os textos literários descrevem paisagens geográficas e relatam passagens históricas de extrema importância para a formação do leitor, bem como citam características de diversos personagens, relacionando-os à vida dos diferentes cenários brasileiros.

Assim, Silva (2003, p. 516) afirma que: "É justamente na troca de experiências e histórias de leitura que, de fato, ocorre a interação entre textos e leitores". Desta maneira, a literatura pode ser algo construído historicamente. Os alunos serão capazes de experienciar o viés cultural e, sobretudo, geográfico nos textos. Ainda para Silva (2003, p. 516):

A leitura é trabalhada no espaço escolar, tendo como objetivo final alguma estratégia de avaliação, o que coloca o aluno diante de uma tarefa árdua: é preciso ler para fazer exercícios, provas, fichas de leitura, resumos, enfim, o ato de ler visa cumprir tarefas escolares.

Vale ressaltar que, no Brasil, a educação passa por mudanças profundas, conforme destaca a Lei de Diretrizes e Bases da Educação Nacional, Lei $n^{\circ}$ 9.394/96, no seu artigo $1^{\circ}$ :

A educação abrange os processos formativos que se desenvolvem na vida familiar, na convivência humana, no trabalho, nas instituições de ensino e pesquisa, nos movimentos sociais e organizações da sociedade civil e nas manifestações culturais.

$\int 1^{\circ}$ Esta lei disciplina a educação escolar, que se desenvolve, predominantemente, por meio do ensino, e instituições próprias.

$\int 2^{\circ}$ A educação escolar deverá vincular-se ao mundo do trabalho e à prática social. 
O papel da escola, no século XXI, é formar alunos críticos, que deixam de ser meros reprodutores do conhecimento, tendo autonomia de relacionar o que leem com o que ocorre no mundo. Assim, Brito (1999, citado por SILVA, 2003, p. 515) afirma que.

\begin{abstract}
A leitura tem de ser pensada não apenas como procedimento cognitivo ou afetivo, mas principalmente como ação cultural historicamente constituída. Essa noção da leitura como ato de posicionamento político diante do mundo, precisa estar presente na prática de sala de aula. Os alunos deveriam ser capazes de "experienciar" o ato de ler como uma ação cultural, em que o leitor tem papel dinâmico nas redes de significação do texto (SILVA, 2003, p. 515).
\end{abstract}

A busca por metodologias que consigam levar o conteúdo ao aluno de maneira mais compreensível, seja através do livro didático, o qual é um importante apoio, não devendo ser o único meio, ou através de outras tecnologias e criatividade, é que irá diferenciar um professor de qualidade.

Cabe ao professor a responsabilidade de levar, à sala de aula, maneiras diversificadas de apresentação destes conteúdos, o que levará a um processo de motivação da turma, pois ensinar Geografia utilizando os recursos disponíveis ao alcance do aluno propicia a busca por novas formas de ver e pensar a Geografia.

No processo de ensino-aprendizagem de Geografia, as palavras-chave das categorias de análise geográfica, por meio dos textos literários no $7^{\circ}$ ano do ensino fundamental, ganham uma conotação mais expressiva com o auxílio da literatura. Nesse contexto, o professor pode se apropriar das várias linguagens e meios de comunicação para ensinar a decodificação, a análise, a interpretação e o uso de dados e informações, e desenvolver, no aluno, novas formas de aprender com poder de reflexão e visão crítica.

Deste modo, o conhecimento geográfico reflexivo e contextualizado será o alicerce que solidificará a interação das vivências e dos conceitos descritos nos textos, causando um estímulo à formação destes através dos textos literários.

É necessário buscar novas práticas de ensinar Geografia, construindo um diálogo presente nos textos literários. Na escola, esta associação leva à discussão dos conceitos geográficos nos textos, proporcionando ao aluno trocar experiências, valorizando a interpretação do aluno frente ao conteúdo. Retomando Lacoste (1989, p. 248), 
Nas descrições ou explicações geográficas não há qualquer 'suspense' para manter o interesse dos alunos e é preciso muito talento e competência para que tal discurso não acarrete aborrecimento.

Em sala de aula o aluno será orientado na leitura dos textos literários, identificando as palavras-chave que serão utilizadas na aula para abordagem daquele conteúdo. Pontuschka (2009, p. 236) assinalou que:

A literatura é fonte de prazer, mas não é só isso. É igualmente modo de conhecer o mundo. Nós não teríamos condições de conhecer o mundo, o todo da vida dos homens, apenas no curto período de tempo de nossas vidas.

A maneira pela qual usamos a palavra, os termos utilizados, as construções sintáticas também forma a consciência e ajuda a reforçar ou desmistificar certos valores. É fato que as conexões entre Geografia e literatura existem, tendo como suporte os discursos teóricos, os quais investigam a interrelação entre concepções de leitura, texto e literatura presentes em sala de aula (SILVA, 2003).

Assim, os geógrafos podem extrair, da literatura, uma grande quantidade de informações e mensagens, que, embora possam parecer subjetivas, apresentam, sob outros "olhos", a realidade, a experiência e os significados de um lugar, estimulando e desenvolvendo o conhecimento através da sensibilidade e das representações mentais. Vlach (1987, p. 43) aponta que "O conteúdo tradicional separa sujeito e objeto. Mas, ao separá-los, faz uma opção pelo objeto do conhecimento, negando, por conseguinte, o sujeito". A literatura permite inferir que há uma ênfase na discussão do espaço enquanto objeto da Geografia.

Autores do cenário nacional e regional, como Raquel de Queiroz, Euclides da Cunha, Durval Muniz, Lurdes Bertol Rocha também destacaram, de maneira peculiar, a importância da Geografia da Região Nordeste presente na literatura.

Documentos fundamentais que subsidiam o professor, como a Lei de Diretrizes e Bases (LDB) e os Parâmetros Curriculares Nacionais (PCN) apresentam-se para análise e reflexão do fazer pedagógico em Geografia. Sendo assim, fazer compreender a disciplina Geografia é importante no processo de construção do espaço geográfico. Conforme os PCN (2000, p. 117): 
A Geografia, ao pretender o estudo dos lugares, suas paisagens e território, tem buscado um trabalho interdisciplinar, lançando mão de outras fontes de informação. Mesmo na escola, a relação da Geografia com a Literatura, por exemplo, tem sido redescoberta, proporcionando um trabalho que provoca interesse e curiosidade sobre a leitura do espaço e da paisagem. É possível aprender Geografia desde os primeiros ciclos do ensino fundamental pela leitura de autores brasileiros consagrados - Jorge Amado, Érico Veríssimo, Graciliano Ramos, Guimarães Rosa, entre outros - cujas obras retratam diferentes paisagens do Brasil, em seus aspectos sociais, culturais e naturais.

Através da utilização da literatura como recurso didático nas aulas de Geografia, o aluno terá oportunidade de se desenvolver criticamente, formando opinião própria. Com essa prática, as aulas tornar-se-ão mais atrativas para quem ensina e, principalmente, para quem aprende, estabelecendo-se, assim, a relação do ensino-aprendizagem. Além de ajudar no desenvolvimento da linguagem e na apresentação de conteúdos programáticos, a literatura tem, indubitavelmente, um imenso potencial de promover diversos processos de aprendizagem.

Os livros podem ser utilizados na sala de aula como uma forma de introduzir temas e lições práticas, como política, questões socioeconômicas e aspectos culturais que afetam e regulam a dinâmica da vida em sociedade (NAIDITCH, 2008, p. 2).

É importante salientar que cabe à Geografia relacionar (posicionar) o sujeito ao espaço no qual este se insere. Incluir atividade em sala de aula, como criação de blogs e grupos virtuais para divulgação dos trabalhos construídos pelos alunos, estimularia o desenvolvimento no processo da aprendizagem.

\section{Metodologia}

Essa pesquisa teve como base uma análise descritiva e bibliográfica, sob a forma de revisão de literatura, atentando para a relevância da importância da literatura no ensino de Geografia, no ensino fundamental.

Os autores utilizados como referencial teórico da nossa pesquisa foram Castrogiovanni (1999), Straforini (2004), Oliveira (1990) e Pontuschka (2009), da área de ensino de Geografia; além de Pereira (2007) e Rocha (2008), sobre as questões literárias no ensino de Geografia. 
A priori foi feito um levantamento bibliográfico referente ao ensino de Geografia na sala de aula, analisando a construção da linguagem geográfica nos textos literários selecionados previamente.

Foram utilizadas quatro coleções para análise de livros didáticos do $7^{\circ}$ ano do ensino fundamental, que tratam de temas relacionados aos conteúdos específicos da Região Nordeste brasileira: Geografia nos dias de hoje, de autoria de Giardino, Ortega e Chianca (2012); Projeto Radix - Geografia, escrito por Pires e Belluci (2012); Geografia, sociedade e cotidiano - espaço brasileiro, dos autores Bigotto, Vitielo e Albuquerque (2012); e Expedições Geográficas, de autoria de Adas (2012).

A aprendizagem deve ser estimulada no ambiente escolar pelo professor de Geografia, criando-se situações para que o aluno perceba a Geografia presente nos textos literários selecionados para suporte do trabalho. Diante dessa observação e da aplicação de textos literários, a relação entre a literatura e a linguagem geográfica permite a integração do aluno e a relação dos assuntos a serem explanados e aplicados. Através dos textos literários ele poderá relacionar os conceitos partindo de suas vivências.

A proposta de ensino de Geografia com textos literários consiste em que, ao elaborar o planejamento anual, o professor de Geografia indique o texto a ser trabalhado na Unidade que corresponda ao tema Região Nordeste, por exemplo, propondo atividades a serem aplicadas aos alunos. É importante que o professor "tenha em mãos" diversas possibilidades ao utilizar as ferramentas pedagógicas necessárias para que os alunos melhor compreendam os textos literários, desde tecnológicas (computadores, datashow, etc.) até as mais simples (papel metro, papel A4, lápis de cor, hidrocor, etc.).

Ao utilizarem ferramentas pedagógicas diferenciadas, os alunos podem relacionar os assuntos, fatos, etc., aprendidos na Geografia, ao seu cotidiano, conhecendo a Região Nordeste brasileira, podendo, então, construir e reconstruir seu espaço geográfico.

\section{IMPORTÂNCIA DO TEXTO LITERÁRIO PARA O ENSINO DE GEOGRAFIA}

No ensino de Geografia, ao desenvolver a leitura de textos literários em sala de aula, o professor deverá, junto com seus alunos, analisar o conteúdo geográfico descrito nas obras, fazendo uma relação entre esses textos, a Geografia e o cotidiano dos alunos, permitindo que eles percebam que a literatura é construção de espaços vividos (SILVA, 1998). 
É possível dizer que, por meio das obras literárias, o conhecimento é muito mais amplo. Através da literatura a visão transdisciplinar é percebida e, assim, "A literatura é capaz de interrelacionar dimensões" (FERREIRA, 2007, p. 112). A aproximação da Geografia com a literatura, no âmbito escolar, sugere que o espaço geográfico é um componente social, o espaço é construído por fenômenos sociais, produto da vivência cotidiana do aluno. De acordo com Spegiorin (2007, p. 31), "O espaço geográfico revela e materializa as relações sociais, propiciando uma reflexão crítica sobre a realidade, o que contribui para o desenvolvimento da cidadania".

Trata-se, portanto, de aliar o texto literário ao tempo histórico e social no contexto escolar, atrelados ao espaço onde o aluno está inserido. Silva (2003, p. 515) afirma que:

Os alunos deveriam ser capazes de 'experienciar' o ato de ler como uma ação cultural, em que o leitor tem papel dinâmico nas redes de significação do texto (grifo do autor).

É justamente nas trocas de experiência que os conceitos peculiares à Geografia serão reforçados. Assim,

É necessário que exista uma intencionalidade político-pedagógica presente em todas as atividades planejadas pelo professor, através da conscientização e da valorização do papel dessa ciência na educação (SPEGIORIN, 2007, p. 31).

A utilização de textos literários é uma possibilidade e potencialidade que promove a interação de fatos narrados pelos autores com o ensino (experiência) interativo do conteúdo. Os textos, sendo trabalhados de forma correta, terão a finalidade de relacionar diversas áreas do conhecimento.

\section{Textos literários para o ensino de Geografia no $7^{\circ}$ ano do ENSINO FUNDAMENTAL}

Um dos livros indicado para trabalhar a Região Nordeste é "Faces do Sertão", de autoria de Luis Fernando Pereira. Nele, o autor descreve a paisagem do sertão nordestino da Bahia, no formato de um verdadeiro diário de bordo, no qual conta a aventura de Ivan e Jorge, que pretendem achar parte da família desconhecida de Jorge no interior da Bahia. Em um dos temas exposto, o autor fala que os sertões haviam mudado. Em terras mais 
altas o verde aparecia mais nas gramíneas, e os arbustos baixos, espinhosos e retorcidos eram mais raros, mas a terra continuava seca, voando com o vento (PEREIRA, 2007). O livro nos leva a descobrir mais da paisagem e do povo que vive nessa região. A caatinga passa a ser apaixonante, pois mesmo com os desafios, a luta é constante. Neste contexto o autor destaca que:

Ivan já se sentia um homem feito de terra. Seu rosto, parte pelo sol, parte pela areia marrom que o vento trazia, estava mais moreno que costume. Ficava pensando em quantas pessoas da sua idade, vivendo em São Paulo, haviam tido a oportunidade de conhecer aquilo que ele estava vendo naquele momento. Ver que a criação de cabritos e cabras era quase regra em todos os sitiozinhos. Que no meio do sertão havia aquele oásis sobre a serra, com cidades tão pequenas quanto um bairro, menores, muito menores até! Cidades de uma rua! Imaginava como seria a vida daquelas pessoas, o que fariam, qual a diversão que tinham quão frequentemente saíam dali para outros lugares (PEREIRA, 2007, p. 32-33).

Rachel de Queiroz, em seu romance "O Quinze", referindo-se à seca do Ceará de 1915, descreve o conflito entre homem e natureza numa temática social, na qual conta a história da migração de um retirante nordestino e sua família. Na escrita está explícita a grandiosidade dos personagens diante da vida na seca. Viver passa a ser um desafio diário para os que estão inseridos nesse entrave da natureza. Queiroz (1930, p. 105-106) esclarece parte da problemática da migração:

O vaqueiro pigarreou, cuspiu para o lado, procurou a frase inicial: - Minha comadre, quando eu saí do meu canto era determinado a me embarcar para o Norte. Com a morte do Josias e a fugida do outro, a mulher desanimou e pegou numa choradeira todo dia, com medo de perder o resto [...]. Eu queria primeiro que a senhora desse uns conselhos a ela; e depois que me arranjasse umas passagenzinhas pro vapor. Esse negócio de morrer menino é besteira [...]. Morre quando chega o dia, ou quando Deus Nosso Senhor é servido de tirar [...]. Conceição mordeu o lábio, pensativa: - Isso não, compadre! Eu acho que a comadre tem uma certa razão [...]. Estas crianças não suportam uma viagem numa gaiola, de Amazonas acima [...].

A obra descreve cenas pitorescas do interior do Ceará, durante o período da seca de 1915. Essa narrativa mostra o cotidiano de duas famílias que, por causa da seca, acabam tendo suas vidas entrelaçadas, uma com maior condição financeira e cultural, e outra com vida humilde e modesta. 


\section{REFERÊNCIAS}

ADAS, M. Expedições Geográficas, $7^{\circ}$ ano. São Paulo: Moderna, 2011.

BIGOTTO, J. F.; VITIELO, M. A.; ALBUQUERQUE, M. A. M. de A. Geografia, sociedade e cotidiano: espaço brasileiro, $7^{\circ}$ ano. 4. ed. São Paulo: Escala Educacional, 2012.

BRASIL. Parâmetros Curriculares Nacionais (PCN). Brasília, DF: Ministério de Educação e Cultura, 2000.

CASTROGIOVANNI, A. C. (org.). Geografia em sala de aula: práticas e reflexões. 2. ed. Porto Alegre: UFRGS,1999.

FERREIRA, H. M. A literatura na sala de aula: uma alternativa de ensino transdisciplinar. 2007. Disponível em: $<$ http://

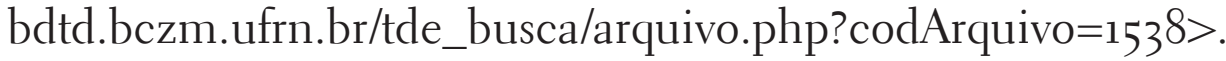
Acesso em: 12 ago. 2012.

GARCIA, V. P.; BELLUCI, B. Projeto Radix: Geografia. 2. ed. São Paulo: Scipione, 2012.

GIARDINO, C.; ORTEGA, L.; CHIANCA, R. B. Geografia nos dias de hoje, $7^{\circ}$ ano. São Paulo: Leya, 2012.

LACOSTE. Y. A Geografia, isso serve, em primeiro lugar, para fazer a guerra. 2. ed. Campinas: Papirus, 1989.

LEI de Diretrizes e Bases da Educação Nacional. Lei $\mathbf{n}^{\circ}$ 9.394, de 20 de dezembro de 1996. Brasília, DF, 1996. Disponível em: <http://portal.mec.gov.br/arquivos/pdf/ldb.pdf>. Acesso: 12 ago. 2012. 
LIMA, A. M., LIMA, J. A. S. Geografia e literatura - Monteiro Lobato e as histórias do mundo para crianças: como o nosso mundo começou. [s.l., [21-]]. Disponível em: <http://www. geografia.fflch.usp.br/graduacao/apoio/Apoio/Apoio_Gloria/2013/1s/flg_O $702 /$ ssoliteraturafilmesensinogeografia.pdf $>$. Acesso em: 12 ago. 2012.

MUNIZ JUNIOR, D. de A. A invenção do Nordeste e outras artes. 5. ed. São Paulo: Cortez, 2009.

NAIDITCH, F. Literatura multicultural e diversidade na sala de aula. [Porto Alegre, [21--]]. Disponível em: $<$ http://revistaseletronicas.pucrs.br/ojs/index.php/faced/article/viewFile/5126/3765>. Acesso em: 12 ago. 2012

PEREIRA, L. F. Faces do Sertão. São Paulo: Escala Educacional, 2007.

QUEIROZ, R. O Quinze. 56. ed. São Paulo: Siciliano, 1930.

ROCHA, L. B. A região cacaueira da Bahia - dos coronéis à vassoura-de-bruxa: saga, percepção, representação. Ilhéus: Editus, 2008.

ROCHA, L. B.; MOREIRA, E. A cidade em tela: Itabuna e Walter Moreira. Ilhéus: Editus, 2010.

SILVA, I. M. M. Literatura em sala de aula: da teoria literária à prática escolar. [S.l., [21-?]]. Disponível em: <http://www. pgletras.com.br/Anais-3o-Anos/Docs/Artigos/Melhorestesesdisserta /5.2_Ivanda.pdf $>$. Acesso em: 12 ago. 2012

SPEGIORIN, M. de T. e S. Por uma outra Geografia Escolar. São Paulo: PUC, 2007.

STRAFORINI, R. Ensinar Geografia: o desafio da totalidade -mundo nas séries iniciais. São Paulo: Annablume, 2004. 
OLIVEIRA, A. U. de (org.). Para onde vai o ensino de Geografia? 2. ed. São Paulo: Contexto, 1990.

PONTUSCHKA, N. N. et al. Para ensinar e aprender Geografia. 3. ed. São Paulo: Cortez, 2009.

VLACH, V. R. F. Fragmentos para uma discussão: método

e conteúdo no ensino da geografia de $1 .{ }^{\circ}$ e $2 .{ }^{\circ}$ graus. In: VESENTINI, J. W. O Ensino da Geografia em questão e outros temas. São Paulo: Terra Livre, 1987. 


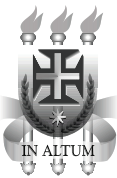

IMPRENSA UNIVERSITÁRIA

Impresso na gráfica da Universidade Estadual de SANTa CruZ - Ilhéus-BA 